\title{
De Nederlandse agrarische sector in internationaal verband - editie 2022
}

Gerben Jukema ${ }^{1}$, Pascal Ramaekers ${ }^{2}$ en Petra Berkhout ${ }^{1}$ (red.)

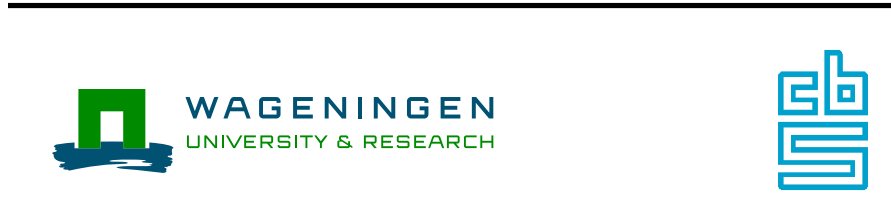


G.D. Jukema, P. Ramaekers en P. Berkhout (Red.), 2022. De Nederlandse agrarische sector in internationaal verband - editie 2022. Wageningen/Heerlen/Den Haag, Wageningen Economic Research en Centraal Bureau voor de Statistiek, Rapport 2022-001. 124 blz.; 40 fig.; 38 tab.; 129 ref.

Dit onderzoek is uitgevoerd door Wageningen Economic Research ${ }^{1}$ en het Centraal Bureau voor de Statistiek ${ }^{2}$ met subsidie van het ministerie van Landbouw, Natuur en Voedselkwaliteit, in het kader van het Beleidsondersteunend onderzoek BO-43-115-007, thema 'Economie', project Landbouwexport in breder perspectief.

Dit rapport beschrijft de ontwikkeling van de Nederlandse handel in landbouwproducten in 2021. Wageningen Economic Research en CBS maken in deze gezamenlijke uitgave de eerste ramingen van de landbouwhandelscijfers voor 2021 bekend en voorzien deze van duiding. Het gaat zowel om de landbouwgoederen als de landbouwgerelateerde goederen. Daarnaast gaat het rapport in op hoeveel Nederland verdient aan de landbouwhandel. Er zijn zes katernen die dieper ingaan op speciale onderwerpen. Voor deze editie zijn dat de gevolgen voor de handel van één jaar Brexit, de effecten van de coronapandemie op de handel, verschillende vormen van handelsbeleid binnen de landbouw, de uiteindelijke bestemming van invoerstromen, de import van biologische goederen in de EU vanuit derde landen en handel en welvaart in internationaal perspectief.

This report describes developments in the Dutch trade in agricultural products in 2021. In this joint edition, Wageningen Economic Research and CBS have published the first estimates of the agricultural trade figures for 2021 and have included an explanation. This concerns both agricultural goods and agriculture-related goods. The report also includes information on revenues from agricultural trade. Six framed sections elaborate on special topics. For this edition, these topics are the consequences of one year of Brexit on trade, the effects of the Corona pandemic on trade, different forms of trade policy in agriculture, the final destination of import flows, the import of organic goods from third countries in the EU, and trade and prosperity in an international perspective.

Dit rapport is gratis te downloaden op https://doi.org/10.18174/561610 of op www.wur.nl/economic-research (onder Wageningen Economic Research publicaties).

(c) 2022 Wageningen Economic Research

Postbus 29703, 2502 LS Den Haag, T 07033583 30, E communications.ssg@wur.nl, www.wur.nl/economic-research. Wageningen Economic Research is onderdeel van Wageningen University \& Research.

\section{(cc) BY.NC}

Dit werk valt onder een Creative Commons Naamsvermelding-Niet Commercieel 4.0 Internationaal-licentie.

(C) Wageningen Economic Research, onderdeel van Stichting Wageningen Research, 2022

De gebruiker mag het werk kopiëren, verspreiden en doorgeven en afgeleide werken maken. Materiaal van derden waarvan in het werk gebruik is gemaakt en waarop intellectuele eigendomsrechten berusten, mogen niet zonder voorafgaande toestemming van derden gebruikt worden. De gebruiker dient bij het werk de door de maker of de licentiegever aangegeven naam te vermelden, maar niet zodanig dat de indruk gewekt wordt dat zij daarmee instemmen met het werk van de gebruiker of het gebruik van het werk. De gebruiker mag het werk niet voor commerciële doeleinden gebruiken.

Wageningen Economic Research aanvaardt geen aansprakelijkheid voor eventuele schade voortvloeiend uit het gebruik van de resultaten van dit onderzoek of de toepassing van de adviezen.

Wageningen Economic Research is ISO 9001:2015 gecertificeerd.

Wageningen Economic Research Rapport 2022-001 | Projectcode 2282500352

Foto's: Shutterstock 


\section{Inhoudsopgave}

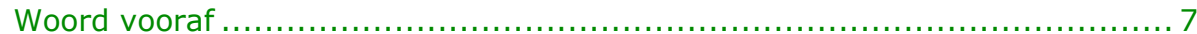

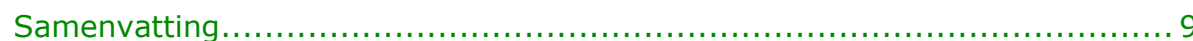

S.1 Hoofdpunten handel in landbouwgoederen $\ldots \ldots \ldots \ldots \ldots \ldots \ldots \ldots 9$

S.2 Hoofdpunten handel in landbouwgerelateerde goederen ......... 10

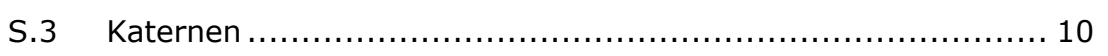

Summary 13

S.1 Key aspects of the trade in agricultural goods .................. 13

S.2 Key aspects of trade in agriculture-related goods ............... 14

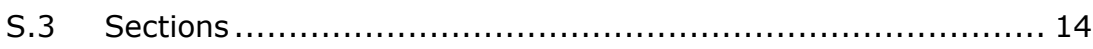

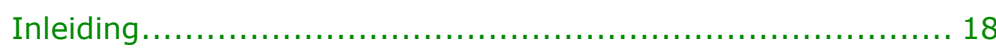

De Nederlandse handel in landbouwgoederen ..................... 20

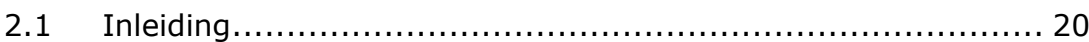

2.2 Landbouwexport voor het eerst boven de 100 miljard ............ 20

2.3 Export van Nederlandse makelij groeit met $10,7 \% \ldots \ldots \ldots \ldots \ldots 21$

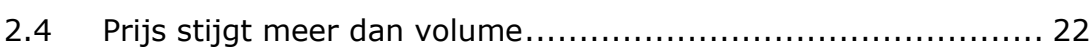

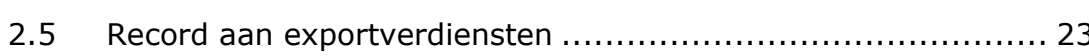

Bestemming en herkomst van de Nederlandse handel in landbouwgoederen.

3.1 Inleiding....

3.2 Grootste exportgroei naar landen dichtbij.....

3.3 Export van Nederlandse makelij naar VK groeit door na de Brexit .....

3.4 Ruim half miljard euro minder import uit VK .................. 28

3.5 Verdiensten aan export naar China gestegen met $150 \% \ldots \ldots \ldots . . .30$
De handel uitgesplitst naar productgroepen ..................... 33

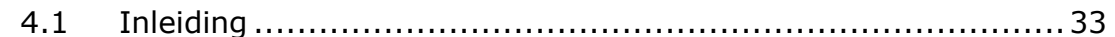

4.2 Sierteeltproducten: sterke toename export- en importwaarde...33

4.3 Vlees: export groeit $6,5 \%$, import ruim $3 \% \ldots \ldots \ldots \ldots \ldots \ldots \ldots . \ldots \ldots$

4.4 Zuivel en eieren: import kent sterkere groei dan export.......... 35

4.5 Aardappelen en groenten: voorzichtige groei export ................36

4.6 Fruit: import en export stabiel ................................... 36

4.7 Dranken: groei export en import ................................ 37

4.8 Oliën en vetten: sterke toename import en export ............... 38

4.9 Overige voeding: toename export en import ........................ 38

4.10 Resten van de voedselindustrie, veevoer: toename export .......39

4.11 Bereidingen van graan, meel en melk: meer import, minder

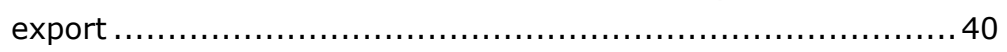

4.12 Bereidingen van aardappelen, groente en fruit: groei export....40

4.13 Cacao: export en import nemen procentueel nagenoeg

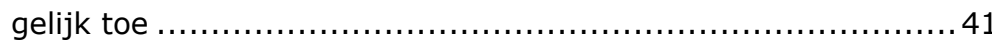

4.14 Zaden en vruchten: import- en exportwaarde nemen toe ........42 42

4.15 Vis en zeevruchten: export en import stijgen ....................43

4.16 Bereidingen van vlees en vis: export groeit naar 2 miljard euro 43

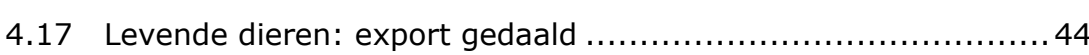

4.18 Suiker en suikerwerken: toename export en import ..............44

4.19 Koffie, thee en specerijen: groei export- en importwaarde ......45

4.20 Tabak en tabaksproducten: sterke procentuele exportdaling .....46

4.21 Meel, mout en zetmeel: export toegenomen.......................46

4 | Wageningen Economic Research Rapport 2022-001 
4.22 Overige producten van dierlijke oorsprong: daling import en onveranderde export.

4.23 Granen: exportwaarde daalt, importwaarde stijgt...............4 47

4.24 Plantensappen: meer export en import ........................ 48

4.25 Vlechtstoffen: hogere importwaarde ........................... 48

4.26 Overige primaire en secundaire landbouwgoederen: sterke

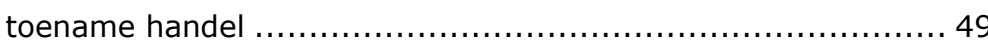

4.27 Exportverdiensten: grootste groei bij vleesexport ................ 50 De handel in landbouwgerelateerde goederen ..................... 53

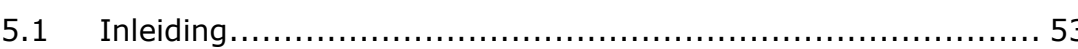

5.2 Voor het eerst meer dan 10 miljard euro tertiaire export ......... 53

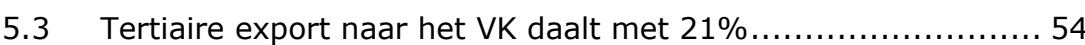

5.4 Export van meststoffen neemt toe met $24 \% \ldots \ldots \ldots \ldots \ldots \ldots \ldots \ldots \ldots \ldots \ldots \ldots \ldots \ldots$

5.5 'Brede' landbouwexportverdiensten meer dan 50 miljard euro .. 57 Gevolgen van de Brexit

6.1 Inleiding 60

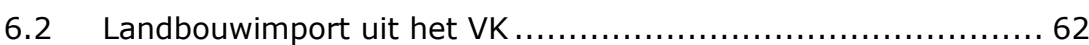

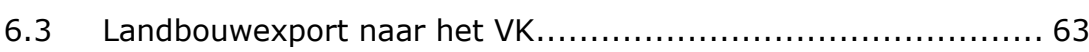

6.4 Wederuitvoer en export van Nederlandse makelij ................64 64

6.5 Samenvattend beeld en vooruitblik ...........................66 De coronapandemie en de gevolgen voor de handel ...............6 69

7.1 Inleiding.

7.2 Nederlandse goederenhandel en corona .......................... 70

7.3 Handel met EU-landen versus niet-EU-landen ................... 70

7.4 Goederensoorten tijdens de coronacrisis ...................... 71

7.5 Compensatie voor coronaverliezen door overheid ................ 73
8.2 Importtarieven 77

8.3 Sanitaire en fytosanitaire maatregelen $\ldots \ldots \ldots \ldots \ldots \ldots \ldots \ldots \ldots \ldots \ldots$

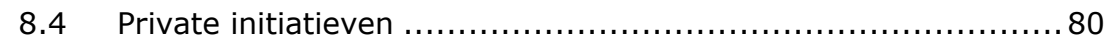

Bestemming import ................................................. 84

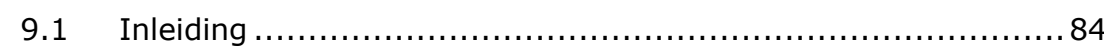

9.2 Ontwikkeling landbouwimport naar bestemming .................. 84

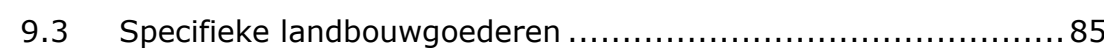

9.4 Herkomstlanden Nederlandse landbouwimport .................. 86 Handel in biologische producten ............................... 89

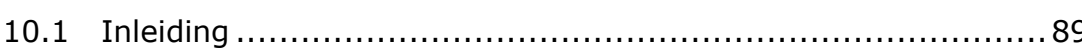

10.2 Biologische importstromen van de EU-27 ...................... 89

10.3 Import van biologische goederen door Nederland ................ 91

10.4 Handel in biologische goederen buiten de EU....................92

Handel en internationale welvaart............................... 95

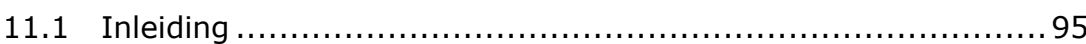

11.2 Internationaal maatschappelijk verantwoord ondernemen .......95

11.3 Instrumenten voor maatschappelijk verantwoord ondernemen.. 96

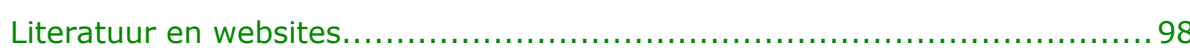

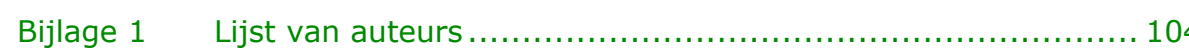

Bijlage 2 Dataverantwoording .............................................. 105

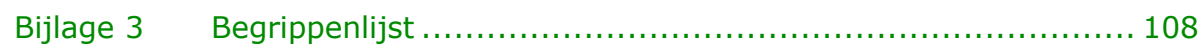

Bijlage 4 Uitgebreide tabellen van de landbouwgoederenhandel naar productgroepen en landen ................................... 110

Bijlage $5 \quad$ Vormen van handelsbescherming ............................. 116

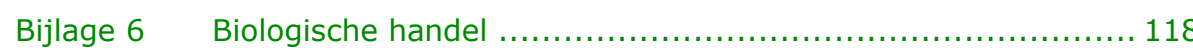

Bijlage $7 \quad$ Structuurgegevens biologische landbouw........................ 120 


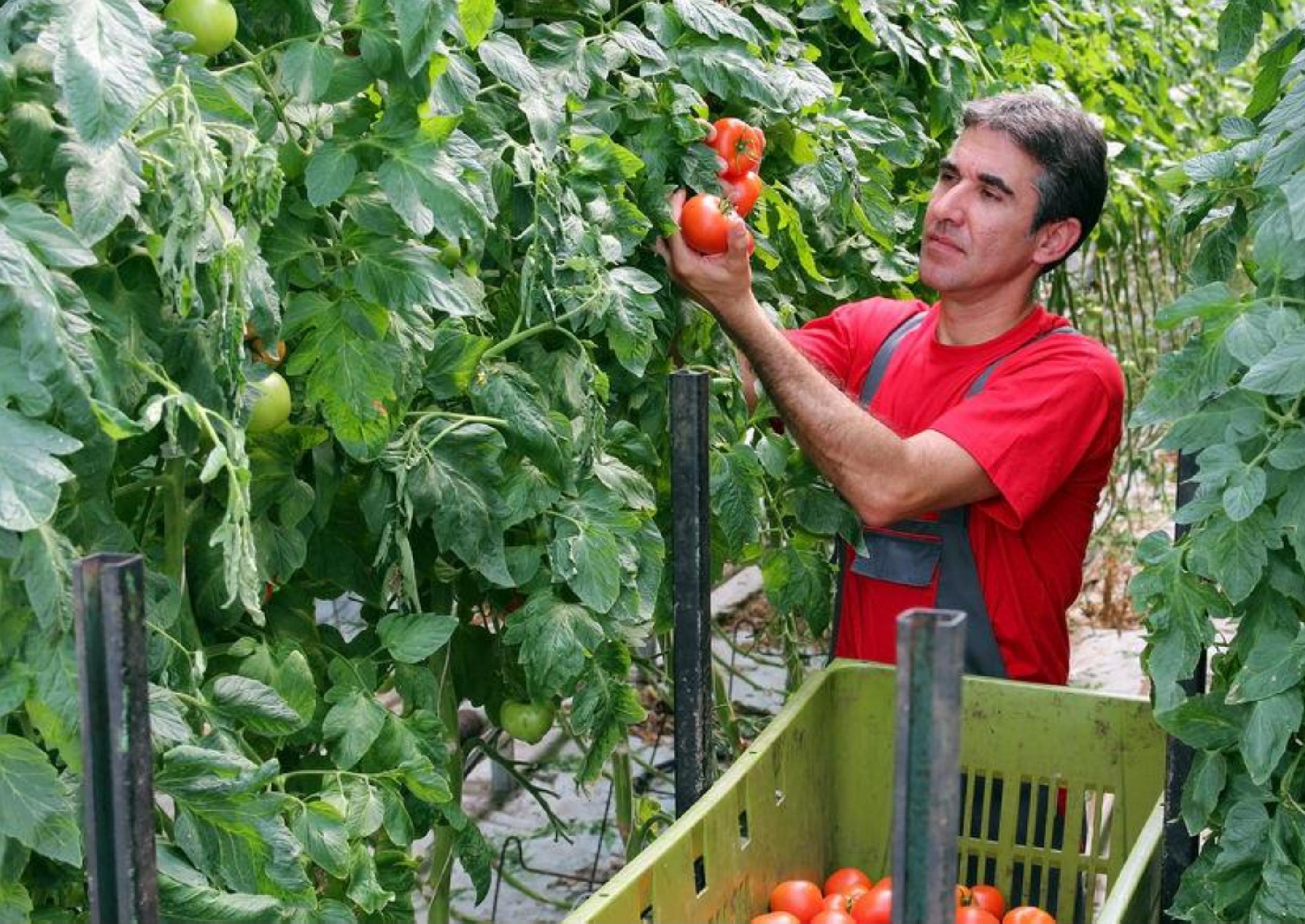




\section{Woord vooraf}

De minister van Landbouw, Natuur en Voedselkwaliteit (LNV) blikt elk jaar terug op de internationale handelsprestaties van de Nederlandse agrosector in het voorgaande jaar. Traditioneel gebeurt dit in januari tijdens de Grüne Woche, de grootste consumentenbeurs op landbouwgebied in Europa en daarbuiten. In de aanloop naar de Grüne Woche maken Wageningen Economic Research en het CBS voor het ministerie van LNV een raming van de internationale prestaties. Dat is ook dit jaar gebeurd, al zal de Grüne Woche in 2022 niet plaatsvinden als gevolg van de coronapandemie.

Naast inzicht in de export- en importcijfers, voor zowel landbouwgoederen als landbouwgerelateerde goederen, bevat de publicatie dit jaar zes katernen waarin een handelsonderwerp uitgelicht wordt. Voor deze editie zijn de onderwerpen de gevolgen van de Brexit een jaar later, de gevolgen van de uitbraak van de coronapandemie, handelsbeleid en handelstarieven, de bestemming van de import van landbouwgoederen, handel in biologische landbouwgoederen en handel en welvaart in internationaal perspectief.

Deze publicatie is tot stand gekomen dankzij het werk van vele auteurs. De concept-publicatie is door verschillende mensen binnen en buiten de betrokken organisaties gelezen en van commentaar voorzien. We danken iedereen hartelijk voor hun inzet.

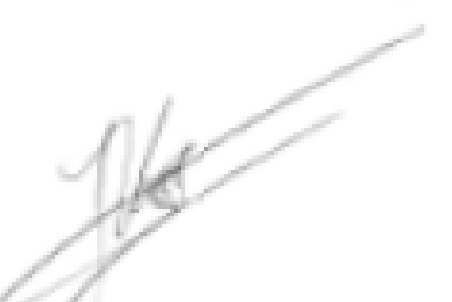

prof.dr.ir. J.G.A.J. (Jack) van der Vorst

Algemeen Directeur Social Sciences Group (SSG)

Wageningen University \& Research

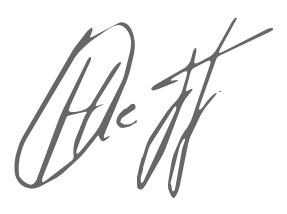

\section{Ir. O. (Olaf) Hietbrink}

Business Unit Manager Wageningen Economic Research

Wageningen University \& Research

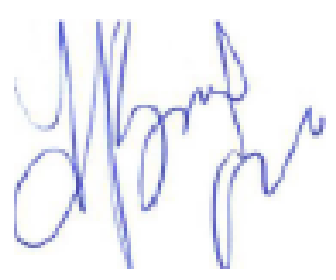

Drs. A (Angelique) Berg

Directeur-Generaal van het Centraal Bureau voor de Statistiek 
H-An'

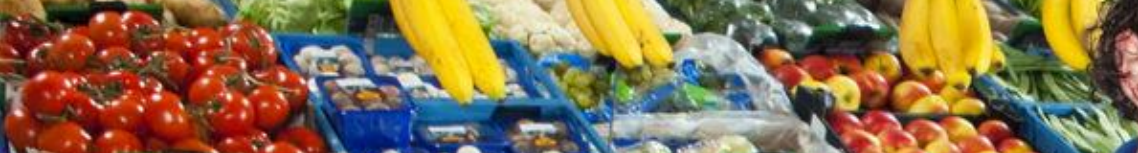

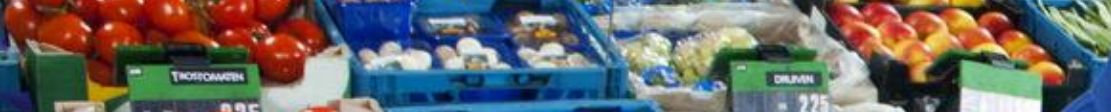
6rimp $7 \times 3$ arta $n-2=3$ . 


\section{Samenvatting}

\section{S.1 Hoofdpunten handel in landbouwgoederen}

- De Nederlandse export van landbouwgoederen (primaire, onbewerkte goederen en secundaire, bewerkte goederen) wordt voor 2021 geraamd op 104,7 miljard euro: dat is 9,4\% hoger dan in 2020 (95,7 miljard euro). Dit is een nieuw record. Zie figuur S.1

- De landbouwgoederen zijn goed voor iets meer dan de helft van het totale goederenhandelsoverschot van Nederland. Zie paragraaf 2.2

- De geraamde landbouwexport van 104,7 miljard euro is onder te verdelen naar 75,7 miljard euro goederenexport van Nederlandse makelij en 29,0 miljard euro wederuitvoer van landbouwgoederen van buitenlandse makelij. Dat is een groei met $10,7 \%$ van de export van Nederlandse makelij ten opzichte van 2020 en een groei met $6,1 \%$ van de wederuitvoer. Zie paragraaf 2.2

- Van de landbouwexport is $27,7 \%$ wederuitvoer van buitenlandse makelij, $72,3 \%$ van de export is van Nederlandse makelij. Dit laatste percentage is een stuk hoger dan bij de export van niet-landbouwproducten $(52,5 \%$ in 2021). Zie paragraaf 2.3

- Het nieuwe exportrecord is te danken aan zowel een stijging van de prijzen als een groei van het exportvolume. Bij de uitvoer is er iets meer prijsstijging dan volumegroei, bij de invoer komt meer dan twee derde van de waardegroei door de stijging van prijzen. Zie paragraaf 2.4

- Ook de import van landbouwgoederen komt op een nieuw record uit. De importwaarde voor 2021 wordt geraamd op 72,5 miljard euro, een groei van $9,9 \%$ ten opzichte van 2020 (65,9 miljard euro). In de periode 2008-2021 is de landbouwimport met $74 \%$ in waarde toegenomen. Dat is meer dan de landbouwexport, die in dezelfde periode met $61 \%$ toenam. Zie paragraaf 2.2

- Het handelsoverschot van Nederland met de landen in de EU-27 is 30,8 miljard euro, waarvan 13,3 miljard euro met Duitsland. Het handelsoverschot met de rest van de wereld (waartoe ook het VK behoort) is 1,4 miljard euro (figuur S.1)
Import

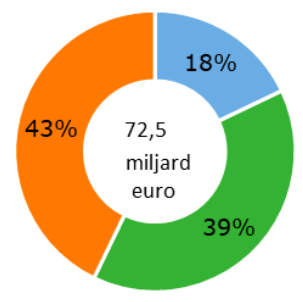

- Duitsland
Handelsbalans

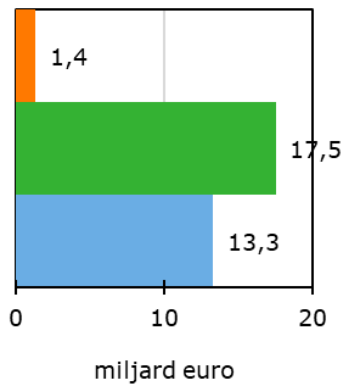

miljard euro
Export

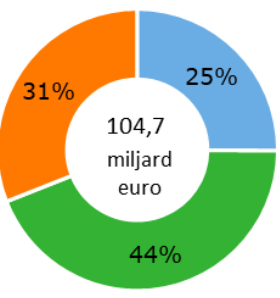

Figuur S.1 Import en export van landbouwgoederen in 2021 naar regio. Bron: CBS tot en met oktober 2021, raming november - december 2021 door Wageningen Economic Research en CBS.

- De meeste landbouwexport gaat in 2021 , net als in voorgaande jaren, naar onze buurlanden. Van de geraamde totale export gaat een kwart naar Duitsland (26,3 miljard euro). Op de tweede plek staat België met $12 \%$ $(12,1$ miljard euro). Daarna volgen als belangrijkste afnemers Frankrijk en het Verenigd Koninkrijk (VK) (beide $8 \%$ of 8,6 miljard euro). Deze vier nabijgelegen landen zijn goed voor $53 \%$ van de totale Nederlandse landbouwexport. Zie paragraaf 3.2

- De EU - exclusief het VK - is verreweg de grootste exportmarkt voor Nederland, met een aandeel van $69 \%$ in 2021 . Het aandeel is gegroeid $(67 \%$ in 2020), omdat de exportwaarde naar EU-landen harder is gegroeid dan de exportwaarde naar landen buiten de EU. Eenzelfde ontwikkeling is zichtbaar bij de landbouwimport (EU-aandeel van bijna 56\% naar ruim 57\%). Zie paragraaf 3.2 en 3.4 
- Sierteeltproducten (12,0 miljard euro), vlees (9,1 miljard euro), zuivel en eieren ( 8,7 miljard euro), groenten ( 7,2 miljard euro) en fruit ( 7,0 miljard euro) zijn bij de export de belangrijkste goederengroepen. De top vijf is in 2021 goed voor $42 \%$ van de totale exportwaarde.

- Bij de import passeren natuurlijke vetten en oliën (7,14 miljard euro) in 2021 nipt fruit (7,07 miljard euro), dat in 2020 nog de koppositie had. Daarna volgen dranken (5,0 miljard euro) oliehoudende zaden en vruchten (4,9 miljard euro) en zuivel en eieren (4,3 miljard euro). Samen zijn deze vijf productgroepen goed voor $39 \%$ van de totale importwaarde van landbouwgoederen.

- Zie hoofdstuk 4 voor de ontwikkelingen per product.

- Wat betreft de landbouwgoederen verdient Nederland het meeste aan de export van sierteeltproducten, zoals bloemen, planten, bloembollen en boomkwekerijproducten, namelijk 6,0 miljard euro. Het gaat hier om de exportwaarde minus de waarde van de import van goederen en diensten die nodig zijn om de goederen te exporteren en te produceren. Op enige afstand volgen vlees (4,6 miljard euro), zuivel en eieren (4,3 miljard), en groenten (3,9 miljard euro). Gemiddeld levert landbouwexport 43 cent op per euro exportwaarde; indien wederuitvoer niet wordt meegerekend, is dat 60 eurocent. Zie paragraaf 4.2

\section{S.2 Hoofdpunten handel in landbouwgerelateerde goederen}

- De Nederlandse exportwaarde van landbouwgerelateerde goederen (tertiaire landbouwgoederen, zoals landbouwmachines en meststoffen) is twee keer zo groot als de Nederlandse import. De exportwaarde van landbouwgerelateerde goederen steeg in 2021 naar een nieuw record van 10,6 miljard euro $(+10 \%)$. De import van landbouwgerelateerde goederen wordt ook geraamd op een nieuw record (5,3 miljard euro), 14\% meer dan in 2020. Zie paragraaf 5.2

- Duitsland, België en Frankrijk vormen de top drie bij de landbouwgerelateerde export. De tertiaire export naar het VK nam af met $21 \%$ in 2021 . Zie paragraaf 5.3

- De export van landbouwmachines (25\%), meststoffen (21\%), machines voor de voedingsmiddelenindustrie ( $18 \%$ ) en kasmaterialen $(15 \%)$ is samen goed voor $80 \%$ van de totale exportwaarde. In absolute zin heeft de grootste groei plaatsgevonden bij de export van meststoffen ( $+0,4$ miljard euro). Zie paragraaf 5.4

- In 2021 komt de som van de geraamde export van landbouwgoederen en landbouwgerelateerde goederen samen (de zogenaamde 'brede' landbouwexport) uit op 115,3 miljard euro. Dat is fors hoger dan de 105,3 miljard euro van 2020. Zie paragraaf 5.2

- Aan een gemiddelde euro exportwaarde van landbouwgerelateerde goederen van Nederlandse makelij verdient Nederland iets meer dan aan een gemiddelde euro exportwaarde van Nederlandse landbouwgoederen: 62 eurocent ten opzichte van 60 eurocent. Bij de totale export, inclusief wederuitvoer, ligt het rendement ook iets hoger (46 tegen 43 eurocent). Zie paragraaf 5.5

- Per euro totale export zijn machines voor de voedingsmiddelenindustrie het meest lucratief. Zonder wederuitvoer leveren kasmaterialen het meest op per euro export. Zie paragraaf 5.5

\section{S.3 Katernen}

\section{De Nederlandse handel met het Verenigd Koninkrijk 2015-2021}

In de periode 2015-2021 heeft de landbouwhandel met het VK duidelijk minder gepresteerd dan de totale landbouwhandel. Dat geldt zowel voor import, wederuitvoer als uitvoer van Nederlandse makelij. Voor import en wederuitvoer geldt dat de krimp die tussen 2015 en 2021 zichtbaar is, geheel in 2021 plaatsvond. De landbouwexport van Nederlandse makelij met bestemming het VK is juist gegroeid in 2021 ten opzichte van 2020 en zelfs iets sterker dan de totale landbouwexport van Nederlandse makelij. Bij het verschil in ontwikkelingen in 2021 speelt in de eerste plaats dat de EU op dit moment al specifieke fytosanitaire en veterinaire controles en administratieve verplichtingen handhaaft (EU-import uit het VK) die de Britse douane pas in 2022 gaat handhaven (EU-export naar het VK). Pas in 2022 zal er dus meer duidelijkheid komen over het totale Brexit-effect op de landbouwexport van Nederlandse makelij. In de tweede plaats gelden er vanaf 1 januari 2021 invoertarieven voor producten waarvan niet kan worden aangetoond dat ze in de EU of het VK zijn geproduceerd. Dit raakt een belangrijk deel van de wederuitvoer en waarschijnlijk ook een deel van de import (Britse wederuitvoer). Ten slotte is het zo dat een aanzienlijk deel van de groei van de landbouwexport van Nederlandse makelij met bestemming het VK (in waarde 
gemeten) is toe te schrijven aan een sterk toegenomen sierteeltexport (met dank aan fors hogere prijzen). Zie verder hoofdstuk 6

\section{De Nederlandse handel in landbouwgoederen en twee jaar coronapandemie}

De handel in landbouwgoederen had relatief minder te lijden onder de coronacrisis dan die van niet-landbouwgoederen, maar tegelijkertijd was de groei in 2021 ook minder. Dat heeft te maken met een geringere conjunctuuren crisisgevoeligheid vanuit de noodzaak van voedingsmiddelen. Binnen de landbouwhandel is de handel met EU-landen in coronatijd harder gegroeid dan de handel met niet-EU-landen. De export van fruit is goed overeind gebleven tijdens de coronapandemie. Voor de exporteurs van sierteelt, vlees, zuivel en eieren, en groenten was het coronajaar 2020 lastiger. Bijna 29 op 100 agribusinessbedrijven ontvingen coronasteun en maakten daarmee iets minder dan gemiddeld gebruik van steunpakketten gedurende de coronacrisis. Van alle internationaal handelende bedrijven in de agribusiness heeft $45 \%$ coronasteun ontvangen van de overheid. Dat is iets meer dan het gemiddelde van alle handelende bedrijven (43\%). De groothandel in landbouwgoederen, voedingswinkels en viskwekers hebben bovengemiddeld vaak steun aangevraagd. Zie verder hoofdstuk 7

\section{Handelsbeleid in de landbouw}

Mede door het in het kader van de WTO afbouwen van importbelemmeringen en het harmoniseren van handelsregels is de internationale handel in landbouw- en voedselproducten de afgelopen 20-25 jaar enorm gegroeid. Toch worden de Nederlandse exporteurs van landbouwproducten buiten de Europese Unie nog steeds met bovengemiddeld hoge importtarieven geconfronteerd (gemiddeld 18\%). Ook hebben exporteurs veel te maken met non-tarifaire maatregelen. In de landbouw gaat het in de eerste plaats om sanitaire en fytosanitaire maatregelen (specifiek gericht op het beschermen van mens, dier en plant tegen ziektes, plagen of verontreinigende stoffen).

Naast de kaders die de WTO stelt aan handel, zijn er zogenaamde UN Guiding Principles on Business and Human Rights (UN, 2011). In 2018 presenteerde de OESO een handreiking voor due diligence (gepaste zorgvuldigheid). De kern van due diligence is dat een bedrijf negatieve gevolgen van de bedrijfsactiviteiten op sociaal en milieugebied voorkomt dan wel aanpakt. Naar verwachting publiceert de Europese Commissie in maart 2022 een richtlijn op het gebied van Sustainable corporate governance. Op basis van deze richtlijn zouden bedrijven in de EU verplicht worden om due diligence toe te passen in hun toeleveringsketens. Het gaat dan zowel om sociale thema's (zoals kinderarbeid, slechte werkomstandigheden, slavernij) als milieu-thema's (zoals klimaat, biodiversiteit). Zie verder hoofdstuk 8

\section{Import naar bestemming}

Van alle landbouwimport komt 70\% uiteindelijk in het buitenland terecht, het merendeel direct als wederuitvoer (43 procentpunt) en het overige deel indirect, na verwerking van de import in Nederland (27 procentpunt). Dit betekent dat $30 \%$ van de landbouwimport in Nederland blijft, waarbij 17 procentpunt direct bestemd is voor Nederlandse consumptie en

13 procentpunt pas wordt geconsumeerd na verwerking in Nederland. De import bestemd voor het buitenland is licht toegenomen van $68,5 \%$ in 2015 tot $70,0 \%$ in 2020. Zie verder hoofdstuk 9

\section{Handel in biologische producten}

$\mathrm{Er}$ is een groeiende behoefte om niet alleen de handel te monitoren, maar ook de eigenschappen van de producten die worden verhandeld. Het gaat dan zowel om kenmerken van het product, als om het productieproces. Het Tracessysteem is een van de weinige openbare bronnen waarbij kenmerken van producten worden gekoppeld aan de GN-handelscode. Dit geeft zicht op de handel in biologische producten. In de EU werd in 2020 voor zo'n 181 miljoen ton aan landbouwgoederen geïmporteerd. Anderhalf procent ( 2,8 miljoen ton) hiervan valt in de categorie biologische producten. Het meest geïmporteerde biologische product in de EU-27 landen is de banaan met bijna een kwart van het totale volume in 2020 . Andere belangrijke producten zijn veevoer in de vorm van perskoeken, sojabonen en koffie. De belangrijkste importeur van biologische landbouwgoederen uit landen van buiten de EU-27 is Nederland. Zie verder hoofdstuk 10

\section{Handel en internationale welvaart}

Inmiddels bestaat zo'n 70\% van de mondiale handel uit internationale waardeketens, waarbij producten een aantal landen passeren, voordat een uiteindelijk product wordt ontwikkeld. Ook Nederland speelt een belangrijke rol in mondiale waardeketens, bijvoorbeeld als het gaat om het importeren en herexporteren van tropische producten als cacao, palmolie, koffie en soja. De laatste tijd worden mondiale waardeketens steeds meer onder de loep 
genomen. Zo is er groeiende bezorgdheid dat handelsliberalisatie leidt tot meer ongelijkheid binnen lage- en midden-inkomenslanden. Maar er lijken ook mogelijkheden: mondiale waardeketens en de daarmee gepaarde

afhankelijkheid tussen landen zouden ook juist een grote rol kunnen spelen in het verbeteren van bovengenoemde omstandigheden. Naast verplichte wet- en regelgeving bestaan er andere initiatieven om problemen in de keten aan te pakken. Er zijn bijvoorbeeld diverse duurzaamheidskeurmerken. Het feit dat een product een keurmerk heeft, is niet altijd een garantie dat de

duurzaamheidsdoelen daadwerkelijk gehaald worden. Hoewel er positieve effecten bekend zijn van certificering, bijvoorbeeld op inkomens van boeren en arbeidsomstandigheden, treden deze effecten niet overal op of zijn ze niet overwegend positief. Zie verder hoofdstuk 11 


\section{Summary}

\section{S.1 Key aspects of the trade in agricultural goods}

- We estimated Dutch exports of agricultural goods (primary unprocessed goods and secondary processed goods) at $€ 104.7$ billion for 2021, which is $9.4 \%$ higher than in 2020 ( $€ 95.7$ billion). This is a new record. See Figure S.1

- Agricultural goods account for just over half of the total trade surplus in goods of the Netherlands. See Section 2.2

- The estimated total exports ( $€ 104.7$ billion) of agricultural goods in 2021 consisted of $€ 75.7$ billion of exported goods of Dutch origin and $€ 29.0$ billion of re-exported agricultural goods originating from other countries. That is a growth of $10.7 \%$ in Dutch-manufactured exports compared to 2020 and a growth of $6.1 \%$ in re-exports. See Section 2.2

- Of total agricultural exports, $27.7 \%$ were re-exports of foreign origin, while $72.3 \%$ were of Dutch origin. In comparison, $52.5 \%$ of exports of nonagricultural products in 2021 were of Dutch origin. See Section 2.3

- The new export record is due to both increased prices and growth in export volume: prices of exports increased slightly more than volume, but more than two-thirds of the value growth in imports was from increased prices. See Section 2.4

- Imports of agricultural goods also reached a new record. The import value for 2021 is estimated at $€ 72.5$ billion, a growth of $9.9 \%$ compared to 2020 ( $€ 65.9$ billion). Between 2008 and 2021, agricultural imports increased in value by $74 \%$ and agricultural exports increased by $61 \%$. See Section 2.2

- The trade surplus of the Netherlands with countries in the EU 27 was $€ 30.8$ billion, of which $€ 13.3$ billion was with Germany. The trade surplus with non-EU countries (including the UK) was $€ 1.4$ billion (Figure S.1).
Import

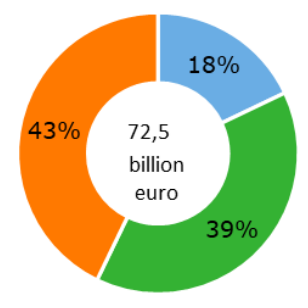

Trade balance

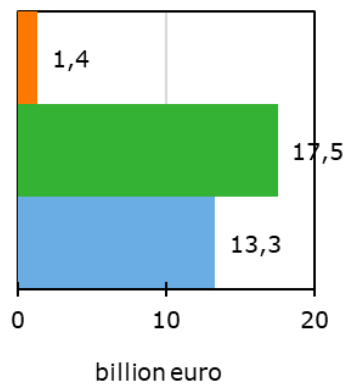

billion euro
Export

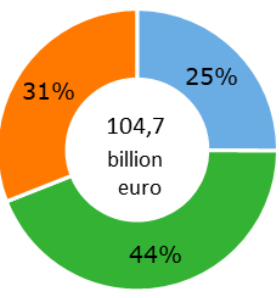

0

$44 \%$
Figure S.1 Imports and exports of agricultural goods in 2021 by region Source: CBS provided data through October 2021; data for NovemberDecember 2021 were estimated jointly by Wageningen Economic Research and CBS.

- As in previous years, in 2021 most agricultural exports went to our neighbouring countries. A quarter of the estimated total exports went to Germany ( $€ 26.3$ billion). Belgium was in second place with $12 \%$ ( $€ 12.1$ billion). This was followed by France and the UK (both $8 \%$ or $€ 8.6$ billion) as most important buyers. These four neighbouring countries accounted for $53 \%$ of total Dutch agricultural exports. See Section 3.2

- The EU - excluding the UK - is by far the largest export market for the Netherlands, with a share of $69 \%$ in 2021 . This is slightly more than in 2020 $(67 \%)$. This growth was due to the greater increase in export value to EU countries than to countries outside the EU. The same development can be seen in agricultural imports - the EU share rose from almost $56 \%$ to more than $57 \%$. See Sections 3.2 and 3.4 
- The main commodity groups in agricultural exports were ornamental horticultural products ( $€ 12.0$ billion), meat ( $€ 9.1$ billion), dairy products and eggs ( $€ 8.7$ billion), vegetables ( $€ 7.2$ billion) and fruit ( $€ 7.0$ billion). These five commodity groups accounted for $42 \%$ of the total export value in 2021 .

- Regarding imports, natural fats and oils ( $€ 7.14$ billion) become the most important commodity group in 2021, taking first position from fruit ( $€ 7.07$ billion). This was followed by the commodity groups drinks ( $€ 5.0$ billion), oilseeds and oleaginous fruit ( $€ 4.9$ billion) and dairy products/eggs ( $€ 4.3$ billion). Together, these five product groups accounted for $39 \%$ of the total import value of agricultural goods.

- See Chapter 4 for the developments per product.

- With regard to agricultural goods, the Netherlands earns the most from the export of ornamental horticultural products, such as flowers, plants, flower bulbs and tree nursery products: $€ 6.0$ billion. The figure pertains to the export value minus the value of imports of goods and services that are required to export and produce the goods. There is a substantial gap between ornamental horticultural products and the next-largest categories: meat ( $€ 4.6$ billion), dairy products and eggs ( $€ 4.3$ billion), and vegetables ( $€ 3.9$ billion). On average, agricultural exports yield 43 cents per euro of export value; if re-exports are not included, this is 60 cents. See Section 4.2

\section{S.2 Key aspects of trade in agriculture-related goods}

- The export value of agriculture-related goods (tertiary agricultural goods such as agricultural machinery and fertilisers) from the Netherlands was twice as large as the import value. In 2021 the export value of agriculturerelated goods rose to a new record of $€ 10.6$ billion ( $+10 \%)$. Imports of agriculture-related goods are also projected to reach a new record

( $€ 5.3$ billion), 14\% more than in 2020 . See Section 5.2

- Germany, Belgium and France are top three destinations for agriculturerelated exports. In 2021 tertiary exports to the UK decreased by $21 \%$. See Section 5.3

- Exports of agricultural machinery (25\%), fertilisers (21\%), machinery for the feed and food industry (18\%) and greenhouse materials (15\%) together accounted for $80 \%$ of the total export value. In absolute terms, the greatest growth has occurred in the export of fertilisers (an increase of $€ 0.4$ billion). See Section 5.4

- In 2021, the sum of the estimated exports of agricultural goods and agricultural-related goods (known as 'broad' agricultural exports) amounted to $€ 115.3$ billion. That is substantially higher than the $€ 105.3$ billion of such exports in 2020. See Section 5.2

- The Netherlands earns slightly more on average per euro of export value of agriculture-related goods of Dutch origin than it does per euro of export value of Dutch agricultural goods: 62 cents compared to 60 cents. The net yield of total exports, including re-exports, is also slightly higher (46 cents against 43 cents). See Section 5.5

- Machines for the feed and food industry are the most lucrative per euro of total exports. Without re-exports, greenhouse materials yield the most per euro of export value. See Section 5.5

\section{S.3 Sections}

\section{Dutch trade with the United Kingdom 2015-2021}

Between 2015 and 2021, agricultural trade with the UK clearly underperformed compared to total agricultural trade. This applies to imports, re-exports and exports of Dutch manufacture. For imports and re-exports, the contraction in trade took place entirely in 2021. Dutch-produced agricultural exports to the UK actually grew in 2021 compared to 2020, even slightly more than total Dutch-produced agricultural exports. The difference in developments in 2021 is firstly because the EU was already enforcing specific phytosanitary and veterinary checks and administrative obligations (EU imports from the UK), but British customs will only begin their enforcement in 2022 (EU exports to the UK). The total effect of Brexit on Dutch agricultural exports will therefore not become clear until 2022. Secondly, from 1 January 2021, import tariffs have applied to products that cannot be proven to have been produced in the EU or the UK. This affects a substantial proportion of re-exports and probably some of the imports (British re-exports) as well. Finally, a significant proportion of the growth in Dutch-manufactured agricultural exports to the UK (measured in value) is attributable to strongly increased ornamental horticulture exports (due to much higher prices). See also Chapter 6 


\section{Dutch trade in agricultural goods and two years of the Covid-19}

\section{pandemic}

Trade in agricultural goods suffered relatively less from the Covid-19 crisis than the trade in non-agricultural goods, but at the same time growth was also less in 2021. Due to the need for food products, the agricultural sector is less sensitive to economic cycles and other crises. During the pandemic, agricultural trade with EU countries grew faster than trade with non-EU countries. Fruit exports have remained intact during the pandemic. The pandemic year 2020 was more difficult for exporters of ornamental horticulture products, meat, dairy products and eggs, and vegetables. Nearly $29 \%$ of agribusiness companies received government pandemic support, which was slightly less than average during the crisis. Of all agribusiness companies in international trade, $45 \%$ have received pandemic support from the government. That is slightly higher than the average for all trading companies (43\%). More wholesalers of agricultural goods, food retailers and aquaculture farmers have applied for government support than average. See also Chapter 7

\section{Trade policy in agriculture}

The international trade in agricultural products and food products has grown enormously over the past 20 to 25 years, which was partly due to the reduction of import barriers and the harmonisation of trade rules within the framework of the WTO. Nevertheless, Dutch exporters of agricultural products to countries outside the EU are still confronted with relatively high import tariffs ( $18 \%$ on average). Exporters are also affected by non-tariff measures. In agriculture, this primarily concerns sanitary and phytosanitary measures (specifically aimed at protecting humans, animals and plants against diseases, pests or contaminants).

Besides the WTO trade frameworks, the UN Guiding Principles on Business and Human Rights (UN, 2011) are also in force. In 2018, the OECD presented a guideline for due diligence. This essentially means that companies are obligated to prevent or account for any negative societal and environmental consequences of their business activities. The European Commission is expected to publish a directive on Sustainable Corporate Governance in March 2022. Based on this directive, companies in the EU would be required to apply due diligence in their supply chains. This concerns societal themes (such as child labour, poor working conditions and slavery) as well as environmental themes (such as climate and biodiversity). See also Chapter 8

\section{Import to destination}

Approximately $70 \%$ of all agricultural imports are eventually re-exported. Of all re-exports, $43 \%$ are re-exported directly and $27 \%$ are re-exported indirectly (after processing in the Netherlands). This means that $30 \%$ of agricultural imports remain in the Netherlands. Of these remaining imports, 17 percentage points are intended for direct consumption and 13 percentage points are consumed after processing in the Netherlands. In the past five years, reexports have increased slightly: from $68.5 \%$ in 2015 to $70.0 \%$ in 2020 . See also Chapter 9

\section{Trade in organic products}

There is a growing need to monitor not only trade in products, but also the properties of the products themselves. This concerns the characteristics of both the product and the production process. The TRACES system is one of the few publicly available sources that links product characteristics to the $\mathrm{CN}$ (combined nomenclature) trade code. This provides insight into the trade in organic products. In 2020, about 181 million tonnes of agricultural goods were imported into the EU. Of this total, 2.8 million tonnes (1.5\%) fell into the category of organic products. The most-imported organic product in the EU-27 countries is the banana, which was responsible for almost one-fourth of the total volume in 2020. The banana is followed by pressed cakes of animal feed, soybeans and coffee. The Netherlands is the largest importer of organic agricultural goods from countries outside the EU-27. See also Chapter 10

\section{Trade and international prosperity}

About $70 \%$ of global trade currently consists of international value chains, in which products pass through a number of countries before a final product is produced. The Netherlands also plays an important role in global value chains, for example with its imports and re-exports of tropical products such as cocoa, palm oil, coffee and soy. Recently, global value chains have come under increasing scrutiny. For example, there is growing concern that trade liberalisation is leading to greater inequality in low and middle-income countries. But there also appear to be opportunities: global value chains and the associated dependencies between countries could also play a major role in 
alleviating inequality. Besides mandatory legislation and regulations, other initiatives, such as various sustainability labels, also tackle problems in the chain. However, such a label on a product does not always guarantee that the sustainability goals are actually being achieved. Although positive effects of certification are known, for example farmers' incomes and working conditions have improved in some cases, these effects do not occur everywhere and may not be predominantly positive. See also Chapter 11 
Hoe presteerde de Nederlandse landbouwsector internationaal in 2021? Traditiegetrouw presenteert de minister van Landbouw, Natuur en Voedselkwaliteit (LNV) tijdens de Grüne Woche in januari de raming van de Nederlandse export van landbouwgoederen over het voorgaande jaar. Vanwege de coronapandemie komt de Grüne Woche 2022 te vervallen. De raming voor de omvang van de Nederlandse landbouwhandel voor het jaar 2021 is echter wel opgesteld door Wageningen Economic Research en het Centraal Bureau voor de Statistiek (CBS).

De publicatie valt uiteen in twee delen. In deel I, hoofdstuk 2 tot en met 5 , komen de ontwikkelingen in de handel in landbouw- en landbouwgerelateerde goederen aan bod (zie kader).

Definitie van landbouwgoederen en landbouwgerelateerde goederen

De landbouwgoederenhandel zoals gebruikt in deze publicatie omvat de eerste 24 goederenhoofdstukken van de internationale handelsstatistieken plus een aantal landbouwgoederen uit overige hoofdstukken volgens de Gecombineerde Nomenclatuur-coderingssystematiek (GN). Bij landbouwgoederen gaat het enerzijds om primaire agrarische producten, zoals varkens, appels, bloemen, bloembollen en tomaten, en anderzijds om verwerkte (secundaire) producten, zoals kaas, frites, chocolade en bewerkingen van groente en fruit.

Naast de handel in landbouwgoederen is in deze publicatie ook de handel in landbouwgerelateerde goederen uitgelicht. Dat zijn aanvullende goederen die geproduceerd worden ten behoeve van de landbouwsectoren in binnen- of buitenland, de zogenaamde tertiaire of landbouwgerelateerde goederen. Het gaat hierbij bijvoorbeeld om landbouwmachines, meststoffen en machines voor de voedingsmiddelenindustrie. Er zijn alleen goederen geselecteerd die enkel aan de agrarische sectoren kunnen worden toegeschreven. Het gebruik van drones in de agrarische sector kan bijvoorbeeld momenteel niet

inzichtelijk worden gemaakt in de internationale handelsstatistiek. Drones kunnen immers door allerlei sectoren worden ingezet.

Meer informatie over de gehanteerde definitie is te vinden in bijlage 2.
Het gaat om de vaste monitoring, zoals deze jaarlijks plaatsvindt. Hoofdstuk 2 gaat in op de belangrijkste trends in de internationale landbouwhandel van Nederland op macroniveau. Het gaat onder meer om inzicht in de totale import en export, waarbij export ook is uitgesplitst in Nederlandse makelij en wederuitvoer, duiding van de ontwikkelingen in termen van volume en prijs en wat wordt verdiend aan de export.

Hoofdstuk 3 beschrijft de grootste herkomst- en bestemmingslanden en de veranderingen hierin. Een geografische uitsplitsing van de export naar Nederlandse makelij en buitenlandse makelij geeft extra duiding aan de cijfers.

Hoofdstuk 4 analyseert de ontwikkelingen van de export en import van Nederland in 2021 aan de hand van de 24 landbouwgoederenhoofdstukken en de groep overige landbouwgoederen. Deze laatste groep bestaat uit individuele producten die uit andere delen van de handelsstatistieken komen, maar wel tot de landbouw worden gerekend.

Hoofdstuk 5 gaat in op de ontwikkelingen in de handel van de landbouwgerelateerde goederen: goederen die ten behoeve van de landbouwsectoren in binnen- en buitenland geproduceerd worden, zoals landbouwmachines.

Deel II van de publicatie, hoofdstuk 6 tot en met hoofdstuk 11, bevat de speciale onderwerpen, waarbij een thema verder wordt uitgediept. Hoofdstuk 6 gaat in op de gevolgen van één jaar Brexit voor de Nederlandse landbouw. In hoofdstuk 7 komen de gevolgen van de coronapandemie aan de orde. Hoofdstuk 8 gaat in op verschillende vormen van handelsbeleid binnen de landbouw. Hoofdstuk 9 geeft inzicht in de uiteindelijke bestemming van invoerstromen. Hoofstuk 10 geeft inzicht in de import van biologische goederen in de EU vanuit derde landen. Hoofdstuk 11 ten slotte gaat in op handel en welvaart vanuit internationaal perspectief. 


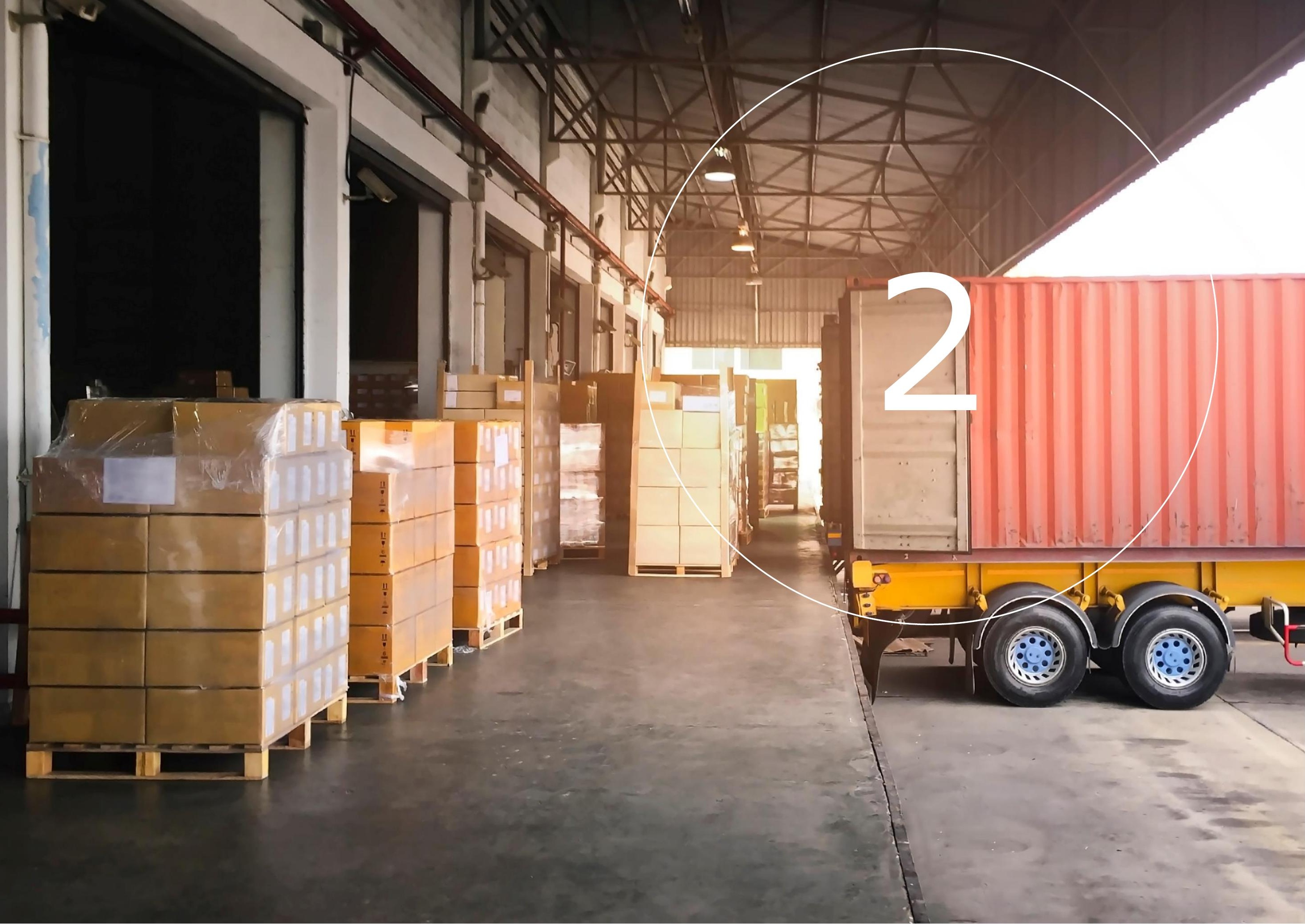




\section{De Nederlandse handel in landbouwgoederen}

\section{$2.1 \quad$ Inleiding}

Dit hoofdstuk beschrijft de belangrijkste trends in de Nederlandse handel in landbouwgoederen op macroniveau. De eerste paragraaf beschrijft de ontwikkeling van de totale landbouwimport en -export. In de tweede paragraaf wordt voor de landbouwexport een onderscheid gemaakt tussen de export van Nederlandse makelij en de wederuitvoer van buitenlandse makelij. In paragraaf drie wordt de ontwikkeling van de handelswaarde afgepeld tot volume- en prijsontwikkelingen. De laatste paragraaf bespreekt wat de Nederlandse economie overhoudt aan de export van landbouwgoederen.

\subsection{Landbouwexport voor het eerst boven de 100 miljard}

Ondanks de voortdurende coronacrisis (zie verder hoofdstuk 7 ) en het eerste jaar van (een deels) effectieve Brexit ${ }^{1}$ (zie verder hoofdstuk 6 ) heeft Nederland in 2021 het vorige landbouwexportrecord van 2020 ruim verbroken (zie figuur 2.1). Dit heeft te maken met een algemeen sterk economisch herstel van het eerste coronajaar en daarnaast ook oplopende prijzen (zie verder paragraaf 2.3).

De Nederlandse landbouwexport wordt voor 2021 geraamd op 104,7 miljard euro en dat is $9,4 \%$ hoger dan in 2020 (toen 95,7 miljard euro). Het is daarmee het zesde landbouwexportrecord op rij. De landbouwimport groeit in waarde ongeveer even hard als de landbouwexport. De toename wordt op $9,9 \%$ geraamd, met een groei van 65,9 miljard euro in 2020 tot 72,5 miljard

1 Formeel is de Brexit effectief sinds 1 januari 2021, maar in de praktijk is dat niet helemaal zo. Zo zijn belangrijke veterinaire en fytosanitaire controles en douaneformaliteiten uitgesteld tot 2022 voor de landbouwexport naar het VK. Brexit is wel geheel effectief voor wat betreft de landbouwimport uit het VK. euro in 2021. Het wordt daarmee het zevende landbouwimportrecord op rij. In de periode $2008-2020$ is de landbouwimport met maar liefst $74 \%$ in waarde toegenomen. Dat is meer dan de landbouwexport, die in dezelfde periode met $61 \%$ in waarde toenam.

Het handelsoverschot, het saldo van uitvoer en invoer, wordt voor 2021 geraamd op 32,2 miljard euro en ook dat is de hoogste waarde ooit gemeten. In 2020 was het nog 29,8 miljard euro. Over de gehele periode 2008-2021 is het overschot met $37 \%$ toegenomen.

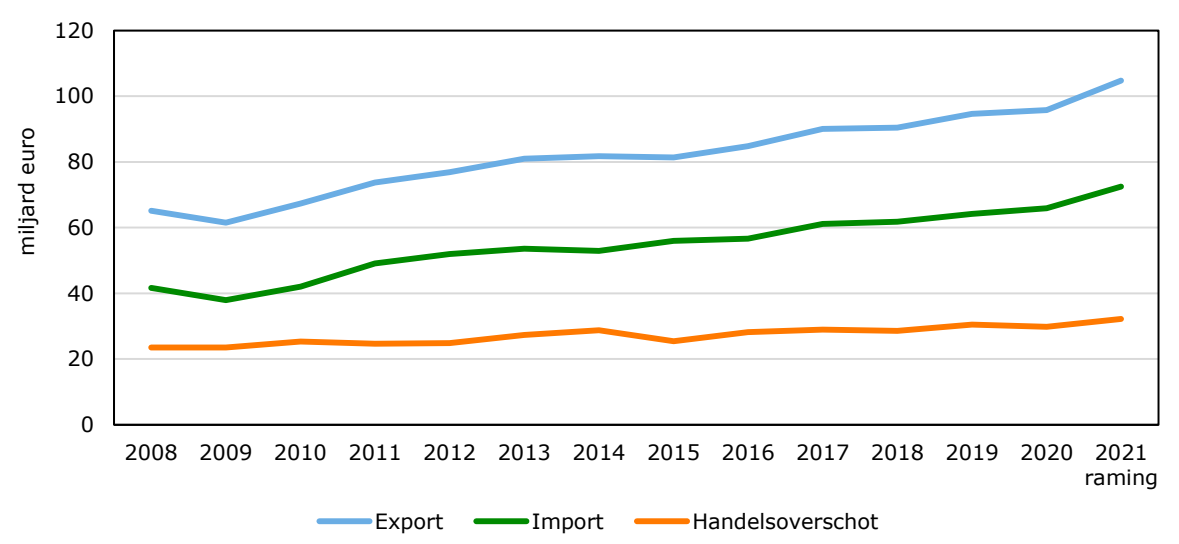

Figuur 2.1 Ontwikkeling waarde Nederlandse landbouwexport, -import en -overschot

Bron: CBS tot en met oktober 2021, raming november-december 2021 door CBS en Wageningen Economic Research. 
In 2021 betrof naar schatting 18,1\% van de Nederlandse goederenexport landbouwgoederen (zie figuur 2.2), fors lager dan in 2020 toen het aandeel $19,8 \%$ bedroeg. Het aandeel in 2021 is beter vergelijkbaar met $2019(18,4 \%)$. Ook het aandeel van de landbouw in de Nederlandse goederenimport is gezakt, van $15,6 \%$ in 2020 tot $14,1 \%$ in 2021 . Ook hier zit het aandeel in de buurt van het 2019-niveau. Wat hier speelt is met name een corona-effect: de handelswaarde bij niet-landbouwgoederen heeft heftiger gereageerd op de coronapandemie dan de handelswaarde bij landbouwgoederen, maar het herstel was ook significanter. Zo zijn olie- en gasprijzen in het eerste coronajaar 2020 flink gedaald en dat heeft vooral effect gehad op de handelswaarde van niet-landbouwgoederen. De noodzaak van voeding maakt ook dat landbouwgoederen minder conjunctuurgevoelig zijn (zie verder hoofdstuk 7 en Jukema et al., 2021). Per saldo blijkt er weinig verschil tussen landbouw en niet-landbouwgoederen: voor beide groepen geldt dat de handelswaarden in 2021 circa 12\% hoger liggen dan in 2019. Dit verklaart dat de landbouwaandelen in 2021 en 2019 vergelijkbaar zijn. Over een lange periode bezien zijn de import- en exportaandelen van landbouwgoederen redelijk stabiel gebleven.

Het hiervoor gepresenteerde toegenomen landbouwoverschot in 2021 vertaalt zich in een iets toenemend aandeel van de landbouw in het totale Nederlandse goederenhandelsoverschot. Het goederenhandelsoverschot bij niet-

landbouwgoederen is namelijk iets minder hard gegroeid. Het landbouwaandeel komt in 2021 uit op 51,1\%; dat is hoger dan in 2020 $(50,6 \%)$, maar lager dan in $2019(55,0 \%)$. Het gaat om forse percentages en het benadrukt nog maar eens dat de landbouw van belang is voor de Nederlandse goederenhandel en de economie als geheel. Wel is het percentage duidelijk lager dan in 2008, toen ging het om een landbouwaandeel van $68,2 \%$. De reden van de daling ligt vooral in ontwikkelingen buiten de landbouw. Zo is het handelsoverschot in chemische producten bijna verdubbeld sinds 2008 (CBS, 2020; 2021a). Daarnaast is Nederland een steeds grotere netto-exporteur van gespecialiseerde machines, zoals chipmachines (CBS, 2021b).

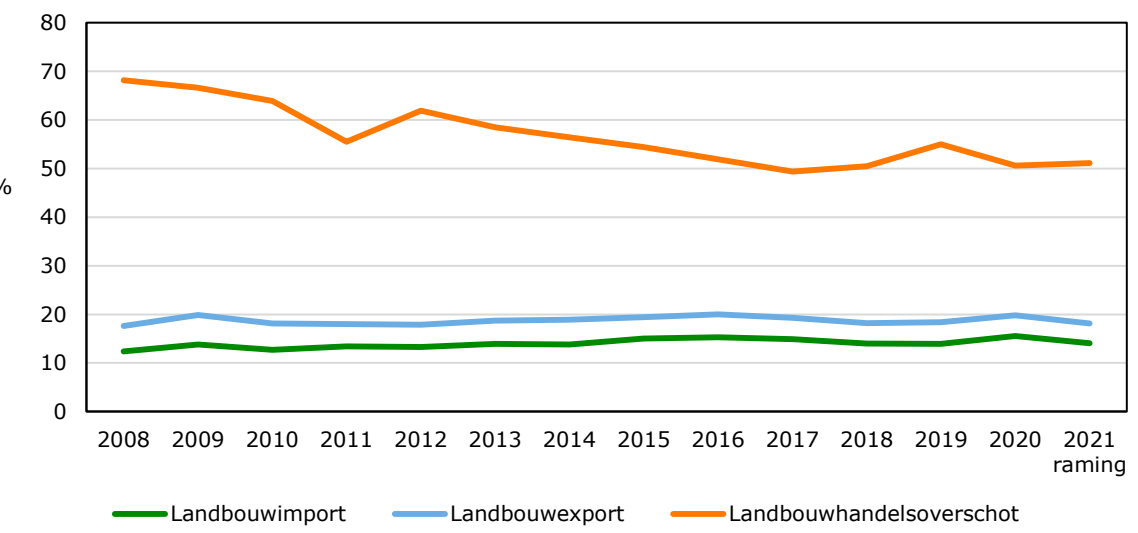

Figuur 2.2 Ontwikkeling landbouwaandeel in totale goederenexport, -import, -overschot

Bron: CBS tot en met oktober 2021, raming november-december 2021 door CBS en Wageningen Economic Research.

\subsection{Export van Nederlandse makelij groeit met $10,7 \%$}

De Nederlandse landbouwexport bestaat uit wederuitvoer (niet of licht bewerkte import die via Nederland doorgaat naar een derde land) en export van Nederlandse makelij. Bij de laatste groep hoort ook de export van significant bewerkte import die door Nederland wordt geëxporteerd (de export van hier geproduceerde chocolade op basis van Ivoriaanse cacaobonen bijvoorbeeld, zie verder Bijlage 3, Begrippenlijst). Het onderscheid tussen beide groepen is van belang, omdat Nederland veel meer verdient aan de export van Nederlandse makelij dan aan wederuitvoer. Dit komt terug in de paragrafen $2.5,3.5,4.27$ en 5.5 waar het concept 'exportverdiensten' verder wordt beschreven.

In 2021 wordt de landbouwexport van Nederlandse makelij geraamd op 75,7 miljard euro en de wederuitvoer van landbouwgoederen op 29,0 miljard (zie figuur 2.3). Dat betekent dat de export van Nederlandse makelij harder is gegroeid (met $10,7 \%$ ) dan de wederuitvoer (met 6,1\%). Met name de 
wederuitvoer met bestemming het Verenigd Koninkrijk (VK) is hard gedaald en hier speelt een Brexit-effect. Door de Brexit is het minder aantrekkelijk geworden om goederen van niet-EU-oorsprong aan het VK te leveren, omdat hierover in principe invoerrechten moeten worden betaald vanaf 1 januari 2021 (zie verder hoofdstuk 6). Het aandeel van wederuitvoer in de totale

landbouwexport is daarmee voor het eerst sinds 2016 gedaald, van $28,5 \%$ in 2020 tot $27,7 \%$ in 2021 . Het percentage in 2021 is nog wel iets hoger dan de percentages in de periode 2016-2019.

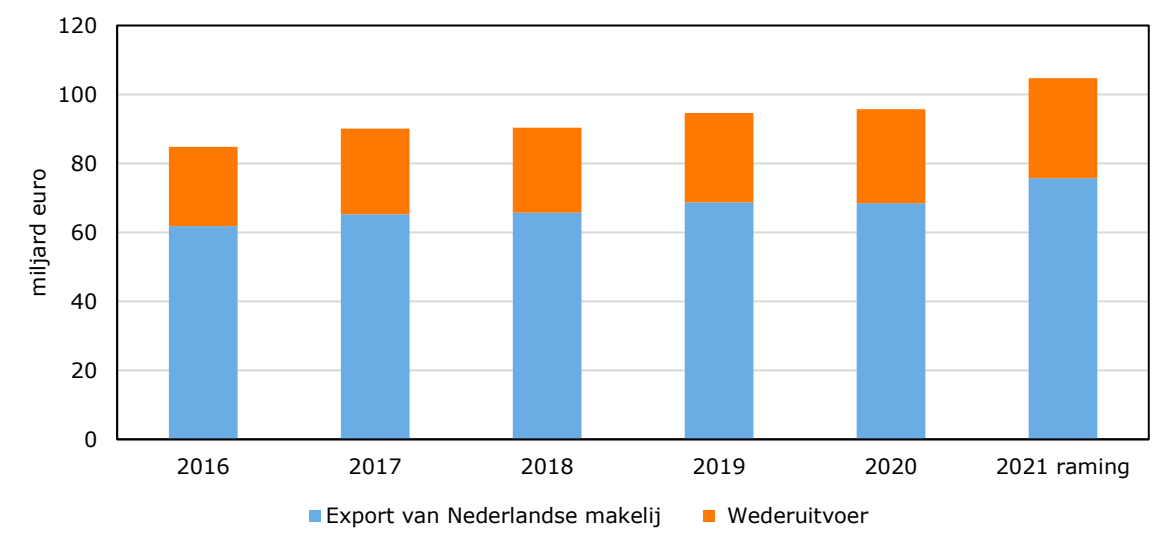

Figuur 2.3 Samenstelling van de Nederlandse landbouwexport Bron: CBS tot en met oktober 2021, raming november-december 2021 door CBS en Wageningen Economic Research.

Landbouwgoederen zijn typische 'Made in Holland'-producten en dat is terug te zien in de vergelijking met andere goederen (zie figuur 2.4). Van de landbouwexport is $27,7 \%$ wederuitvoer van buitenlandse makelij, $72,3 \%$ van de export is van Nederlandse makelij. Dit laatste percentage is een stuk hoger dan bij de export van niet-landbouwproducten (52,5\% in 2021). In de totale goederenexport is $56,5 \%$ van Nederlandse makelij en $43,5 \%$ van buitenlandse makelij. Bij zowel landbouwgoederen als bij niet-landbouwgoederen is het belang van wederuitvoer in 2021 afgenomen. Niet-landbouwgoederen hebben net als landbouwgoederen te maken met een door de Brexit sterke afnemende wederuitvoer naar het VK.

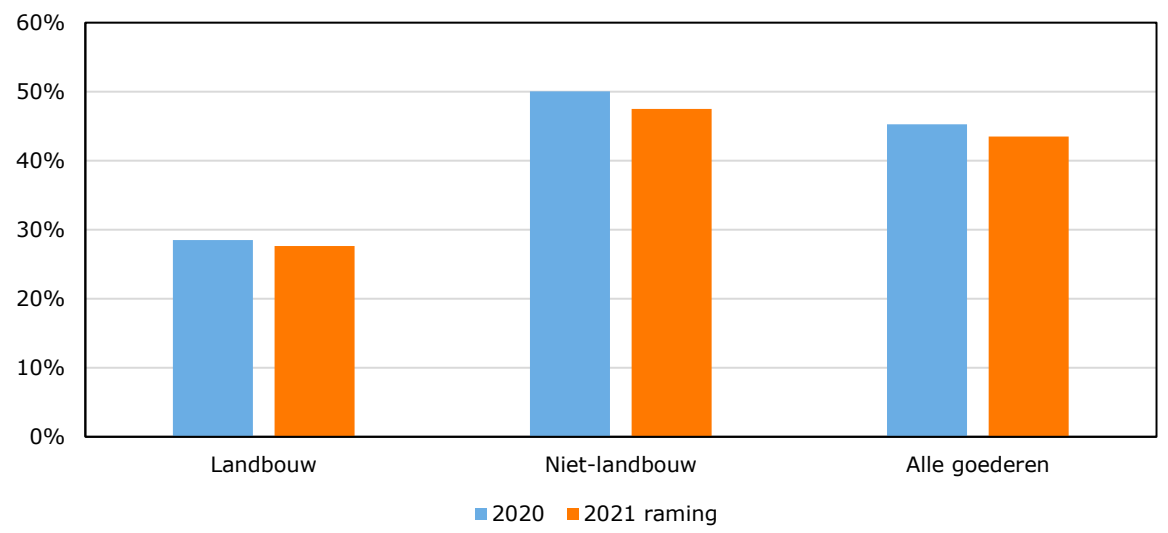

Figuur 2.4 Aandeel wederuitvoer in de Nederlandse goederenexport Bron: CBS tot en met oktober 2021, raming november-december 2021 door CBS en Wageningen Economic Research.

\subsection{Prijs stijgt meer dan volume}

Naast het onderscheid wederuitvoer/uitvoer Nederlandse makelij is het van belang om onderscheid te maken in volume en waarde. Deze publicatie gaat voor het grootste deel over ontwikkelingen van handelswaarden (euro's die over de Nederlandse grens gaan). Een toename van handelswaarde betekent echter niet automatisch ook een toename van het exportvolume. Een waardemutatie is het resultaat van een volume- en een prijsontwikkeling. $\mathrm{Bij}$ de nationale rekeningen van het CBS worden deze prijs- en volumemutaties berekend, ook voor landbouwgoederen.

Voor de landbouwexport laat figuur 2.5 zien dat de prijs van landbouwgoederen iets harder is gegroeid dan het landbouwvolume is toegenomen. Beide tonen een bestendige groei in 2021. Vertaald naar de raming van deze publicatie (9,4\% groei exportwaarde in 2021) betekent dit een toename van het volume van ruim $4 \%$ en een prijsstijging van ruim $5 \%$ in 2021.

Bij de landbouwimport zijn de verschillen tussen volume- en prijsontwikkeling groter. Hier zien we een duidelijke grotere prijsstijging dan toename van het 
volume. Vertaald naar de raming van deze publicatie $(9,9 \%$ groei

importwaarde in 2021) betekent dit een toename van het volume van circa $3 \%$ en een prijsstijging van bijna $7 \%$ in 2021.

Wereldwijd zijn er hoge voedselprijzen. De wereldmarktprijzen liggen zelfs op het hoogste niveau sinds september 2011. Zo gingen de prijzen van onder meer suiker, granen, plantaardige oliën, vlees en zuivel omhoog (FAO, 2021). In Nederland speelt daarnaast een betere prijs voor bloemen. Door veel vraag, duur transport, de Brexit en hoge energieprijzen liggen de bloemenprijzen flink hoger dan in 2020 (Floridata, 2021). Voor de landbouw in het algemeen geldt dat de vraag stijgt door langzaam herstel van de coronapandemie en doordat landen hun voedselvoorraden willen aanvullen (AD, 2021).

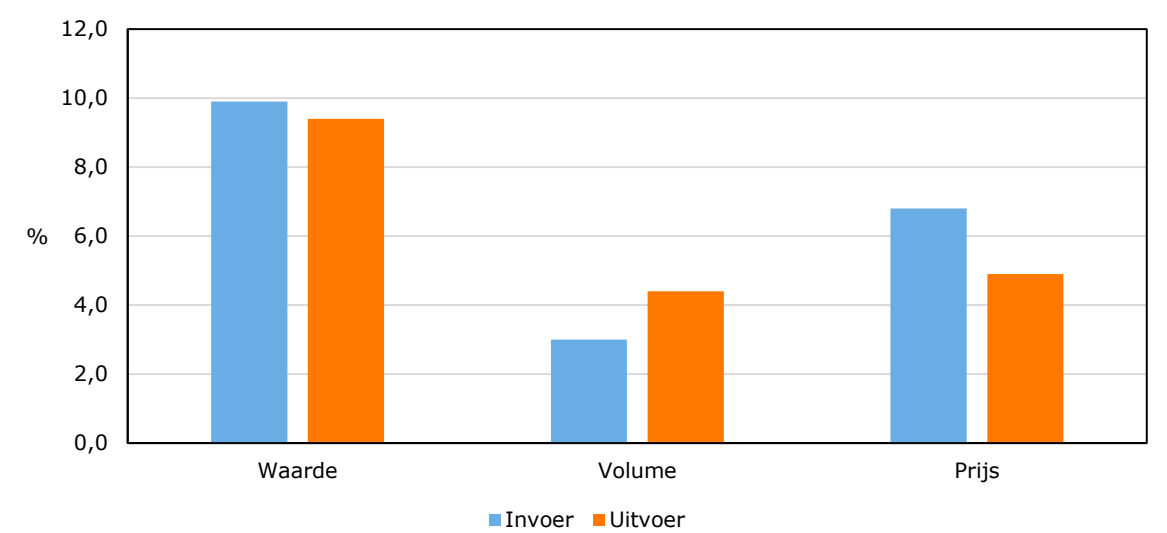

Figuur 2.5 Geschatte ontwikkeling landbouwwaarde, -volume en -prijs, 2020-2021 (NR-definities)

Bron: CBS (waarde: raming paragraaf 3.1; prijs en volume: verhoudingen nationale rekeningen in de eerste drie kwartalen van 2021).

Zowel bij de invoer als bij de uitvoer van landbouwgoederen is te zien dat de combinatie prijsstijging en tegelijk volumegroei het meest voorkomt

(tabel 2.1). Bij de invoer geldt dit voor $36 \%$ van alle goederen en bij de uitvoer voor $49 \%$. Dit komt overeen met het algemene beeld van volumegroei en prijsstijging van figuur 2.5 . Het omgekeerde komt bij zowel invoer (9\%) als uitvoer (4\%) juist heel weinig voor. De op een na meest voorkomende combinatie betreft prijsstijging in combinatie met volumedaling in 2021 (bij 27 tot $29 \%$ van de landbouwgoederen).

Tabel 2.1 Ontwikkeling van volume en prijs voor

45 landbouwproductgroepen, 2020-2021

\begin{tabular}{lll} 
Uitvoer & Volume daalt & Volume groeit \\
\hline Prijs daalt & 2 goederengroepen & 9 goederengroepen \\
\hline Prijs groeit & 12 goederengroepen & 22 goederengroepen \\
\hline Invoer & Volume daalt & Volume groeit \\
\hline Prijs daalt & 4 goederengroepen & 12 goederengroepen \\
\hline Prijs groeit & 13 goederengroepen & 16 goederengroepen \\
\hline
\end{tabular}

Bron: CBS (nationale rekeningen).

\subsection{Record aan exportverdiensten}

Voor het hele jaar 2021 is ook een raming gemaakt van de verdiensten aan de Nederlandse export van landbouwgoederen. Het CBS maakt deze berekeningen met behulp van waardeketenonderzoek op basis van input-outputtabellen van de nationale rekeningen. Daarbij wordt rekening gehouden met de gehele exportketen van producten en met lucratieve en minder lucratieve export. Exportverdiensten zijn hier wat de Nederlandse economie overhoudt aan de export van landbouwgoederen, na aftrek van de daarvoor gemaakte kosten (invoer van grondstoffen, diensten, halffabricaten en de invoer voor wederuitvoer).

In lijn met paragraaf 2.2 zijn de verdiensten aan zowel de landbouwexport van Nederlandse makelij als de wederuitvoer van landbouwgoederen in 2021 toegenomen. Nederland verdient daarbij per euro export relatief weinig aan wederuitvoer (11 eurocent) in vergelijking met de export van Nederlandse makelij (60 eurocent). Zo is het aandeel van wederuitvoer in de totale landbouwexportverdiensten $8,6 \%$ en dat is veel minder dan de eerder gepresenteerde $27,5 \%$ bij de (bruto)exportwaarde. 
Voor 2021 worden de totale verdiensten aan de export van landbouwgoederen geraamd op 46,1 miljard euro, waarvan 42,1 miljard dankzij de export van Nederlandse makelij en 4,0 miljard euro door wederuitvoer (zie figuur 2.6). In 2020 ging het om 42,5 miljard euro totale exportverdiensten. Daarmee komen de exportverdiensten aan landbouwexport, net als de exportwaarde, fors hoger uit in 2021 dan in 2020. Zowel de export van Nederlandse makelij als de wederuitvoer noteren een duidelijk record.

In 2021 ligt het aandeel van landbouw in de totale Nederlandse goederenexportverdiensten op 30,7\%. Dat is iets lager dan in 2020 (toen $31,2 \%)$. De bijdrage van de landbouwexportverdiensten aan de Nederlandse economie was in 2020 5,3\% (aandeel in het Nederlandse bbp). Voor 2021 is het aandeel nog niet te geven.

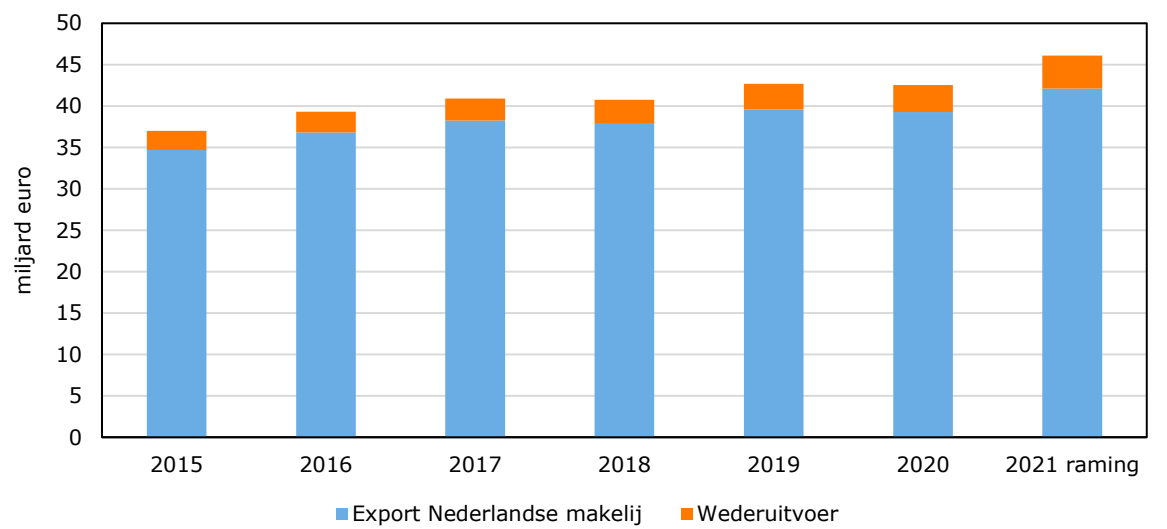

Figuur 2.6 Ontwikkeling verdiensten aan Nederlandse landbouwexport Bron: CBS (waardeketenonderzoek). 

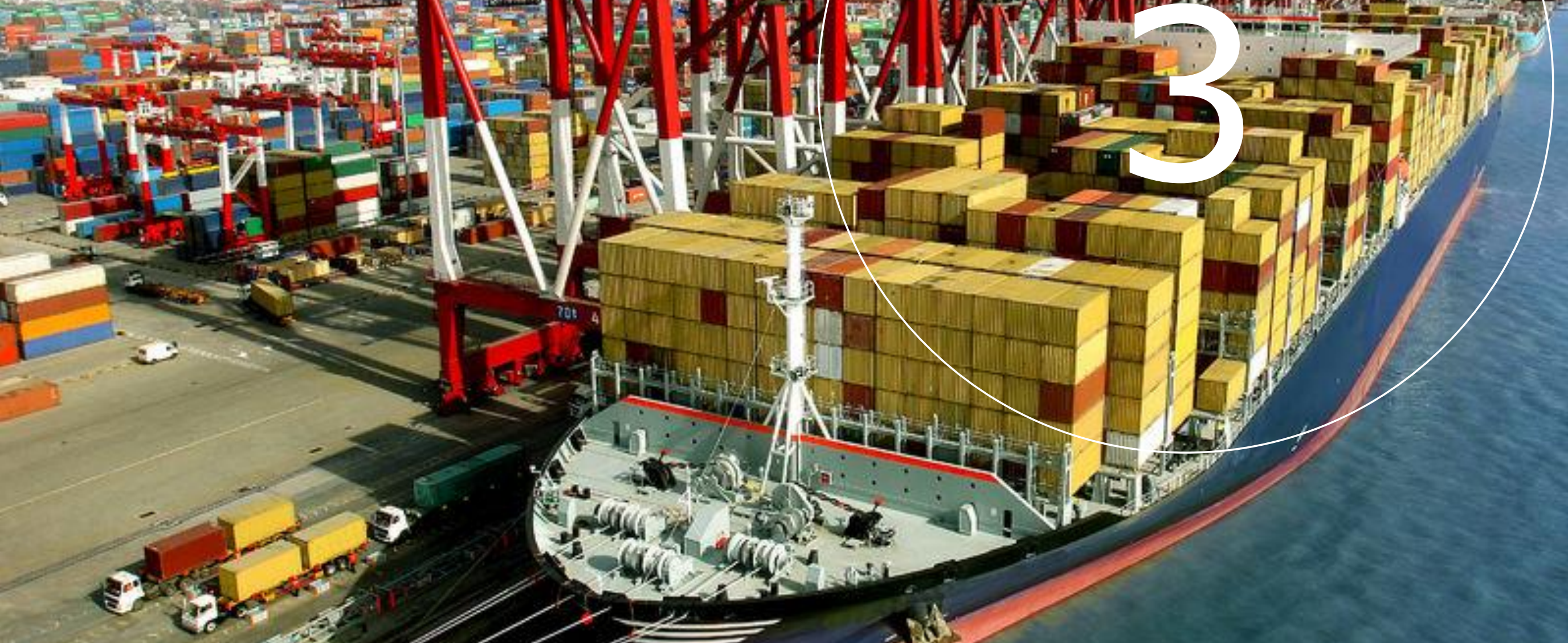


\section{Bestemming en herkomst van de Nederlandse handel in landbouwgoederen}

\section{$3.1 \quad$ Inleiding}

Dit hoofdstuk behandelt de bestemming en herkomst van de handelsstromen. Paragraaf 3.1 gaat in op de belangrijkste bestemmingen van de Nederlandse landbouwexport, paragraaf 3.2 doet dat specifiek voor de export van

Nederlandse makelij. Paragraaf 3.3 beschrijft de belangrijkste herkomstlanden bij de import van landbouwgoederen. Het hoofdstuk wordt afgesloten met de verdiensten aan de landbouwexport uitgesplitst naar bestemming.

\subsection{Grootste exportgroei naar landen dichtbij}

In 2020 is de Brexit formeel een feit geworden, maar er is pas sprake van een effectieve Brexit vanaf 2021 (zie verder hoofdstuk 6). In deze publicatie wordt het Verenigd Koninkrijk voor geheel 2020 en 2021 tot de niet-EU-landen gerekend. Zo kunnen EU en niet-EU met elkaar worden vergeleken door de tijd. Figuur 3.1 laat zien dat zelfs zonder het VK met afstand de meeste landbouwexport voor EU-landen bestemd is. In 2021 betrof het aandeel 69\%, iets meer dan in 2020 (67\%). Het aandeel is toegenomen doordat de export naar EU-landen fors harder groeide in 2021 (met 13\%) dan de export naar niet-EU-landen (met 3\%).

De mindere prestatie van de export naar niet-EU-landen is terug te zien bij de export naar de tien belangrijkste bestemmingen voor de Nederlandse landbouwexport. De top tien bestaat uit zeven EU-landen en drie niet-EUlanden: China, het VK en de VS. De ontwikkeling van de export naar het VK $(+0,4 \%)$ en China $(+1,4 \%)$ was in 2021 het minst gunstig van de tien landen genoemd in figuur 3.2. De ingang van de effectieve Brexit per 1 januari 2021 speelt hierbij een rol, zeker wat betreft de wederuitvoer (zie hoofdstuk 6 ). De export naar de VS zit net onder het totaalgemiddelde met $9 \%$ groei.

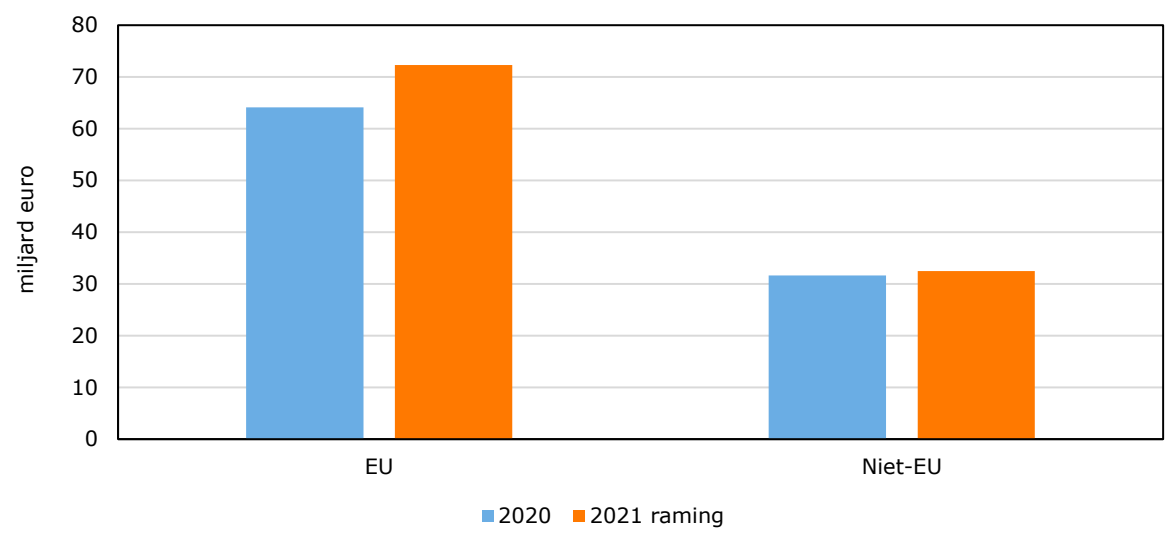

Figuur 3.1 Landbouwexport naar EU en niet-EU

Bron: CBS tot en met oktober 2021, raming november-december 2021 door CBS en Wageningen Economic Research.

De belangrijkste tien bestemmingen voor de landbouwexport zijn goed voor $71,9 \%$ van de totale landbouwexport: dat is iets meer dan in $2020(71,6 \%)$. De landbouwexport is dus sterk gericht op een beperkt aantal bestemmingen. Duitsland $(25 \%)$, België (12\%), Frankrijk en het VK (beide $8 \%$ ) zijn van oudsher de belangrijkste vier bestemmingen. Op enige afstand volgen Italië, China (beide 4\%), Spanje, Polen, VS (alle 3\%) en Denemarken (2\%).

Zoals al genoemd heeft de export naar EU-landen algemeen goed gepresteerd met een hoge exportgroei naar België (13\%), Frankrijk (14\%), Italië (17\%), Spanje (21\%), Polen (19\%) en Denemarken (22\%). Alleen de groei van de export naar Duitsland is beneden gemiddeld (7\%). 
Tussen 2020 en 2021 hebben maar liefst vier wisselingen plaatsgevonden tussen de landen in de rangschikking van belangrijkste bestemmingen. Zo heeft Frankrijk het VK gepasseerd (van vier naar drie), Italië passeerde China (van zes naar vijf), Spanje passeerde Polen (van acht naar zeven) en Denemarken is de nieuwe nummer tien (in plaats van Zweden) (figuur 3.2).

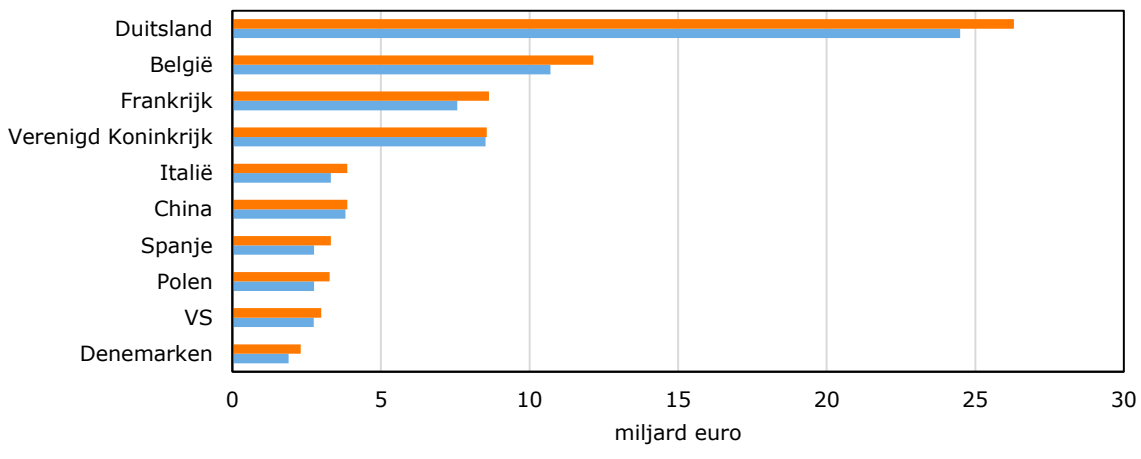

- 2021 raming $=2020$

Figuur 3.2 Top tien bestemmingen Nederlandse landbouwexport in 2021 Bron: CBS tot en met oktober 2021, raming november-december 2021 door CBS en Wageningen Economic Research.

De vijf grootse groeiers voor wat betreft absolute exportwaarde zijn allemaal EU-landen: Duitsland ( $+1,8$ miljard euro), België $(+1,4$ miljard), Frankrijk (+1,1 miljard), Spanje en Italië (beide $+0,6$ miljard) (figuur 3.3). Deze vijf landen vertegenwoordigen $60 \%$ van de totale exportgroei. De volgende landbouwgoederen kenden daarbij een sterk groeiende exportwaarde: sierteelt (Duitsland, Frankrijk, Italië en Spanje), oliehoudende zaden en vruchten (vooral Duitsland), natuurlijke vetten en oliën (vooral Duitsland en België), suiker en suikerwerk (vooral België), cacaoproducten en dranken (vooral Frankrijk), vlees (vooral Spanje) en vis en zeevruchten (vooral Spanje en Italië).
De grootste dalers zijn allemaal landen van buiten de EU: Australië, Senegal, Rusland, Vietnam en Marokko. Het gaat hier om relatief kleine afnames van tussen de 22 en 47 miljoen euro ten opzichte van 2020.

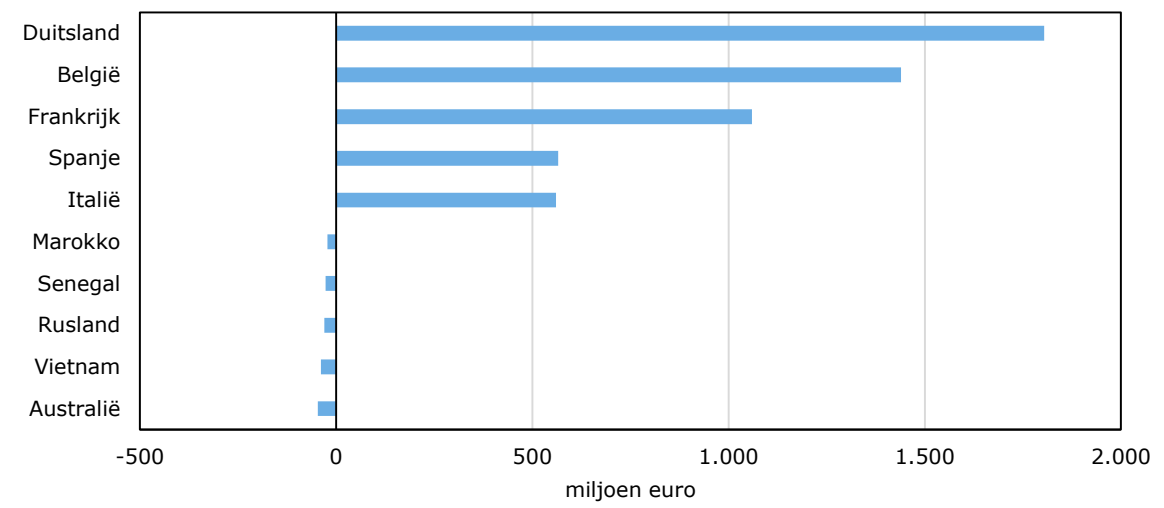

Figuur 3.3 Top vijf stijgers en dalers 2020-2021 in verandering absolute uitvoerwaarde

Bron: CBS tot en met oktober 2021, raming november-december 2021 door CBS en Wageningen Economic Research.

\subsection{Export van Nederlandse makelij naar VK groeit door na de Brexit}

Eerder is opgemerkt dat Nederland veel meer overhoudt aan de export van Nederlandse makelij dan aan de wederuitvoer van buitenlandse makelij. Om deze reden worden de cijfers van de vorige paragraaf in deze paragraaf 'gezuiverd' van wederuitvoer (figuur 3.4). Het beeld blijft echter voor een groot deel ongewijzigd: dezelfde tien bestemmingen komen naar voren en ook de volgorde is vergelijkbaar. Een opvallend verschil is wel dat het VK nu boven Frankrijk staat. Dat heeft ermee te maken dat met name de wederuitvoer naar het VK het zwaar heeft gehad sinds de effectieve Brexit en deze telt hier niet mee. De landbouwexport van Nederlandse makelij naar het VK heeft juist goed gepresteerd met een groei van 14\%. Een ander verschil betreft de VS. Er gaat, 
in vergelijking met andere landen, relatief weinig wederuitvoer naar dat land en zonder wederuitvoer is de VS niet de negende, maar de zevende

exportbestemming. De VS is onder andere de grootste afnemer van Nederlands bier. Eenzelfde verhaal geldt voor China: ook dit land stijgt in de rangschikking na zuivering voor wederuitvoer. Er gaat veel babymelkpoeder en varkensvlees naar China en dat is voor het overgrote deel van Nederlandse makelij.

Omdat relatief veel export naar Duitsland wederuitvoer betreft neemt het Duitse belang na aftrek van deze wederuitvoer af. Duitsland heeft dan niet een aandeel van $25 \%$ in het totaal, maar van $23 \%$. Het Chinese aandeel neemt dan juist toe van 4 tot 5\% en het VK gaat van 8 naar 9\%. In 2021 laten negen van de tien grootste bestemmingen een toename zien van de landbouwexport van Nederlandse makelij. Enkel de export van Nederlandse landbouw naar China kent een afname $(-2 \%)$. Hier speelt een flinke afname van de export van babymelkpoeder en ook een afname van de exportwaarde van varkensvlees (zie verder hoofdstuk 4).

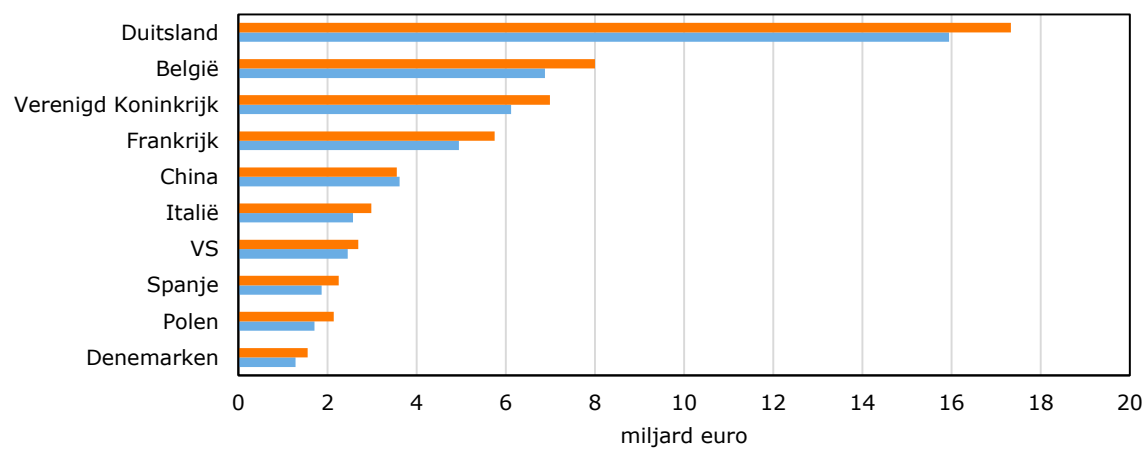

$=2021$ raming $=2020$

Figuur 3.4 Top tien bestemmingen landbouwexport van Nederlandse makelij in 2021

Bron: CBS tot en met oktober 2021, raming november-december 2021 door CBS en Wageningen Economic Research.
Bij de grootste stijgers en dalers voor wat betreft de absolute ontwikkeling van de export van Nederlandse makelij in 2020 (figuur 3.5) komen veel landen terug die we eerder zagen bij de absolute totale exportontwikkeling (figuur 3.3). Zo staan Duitsland ( $+1,4$ miljard euro), België $(+1,1$ miljard) en Frankrijk $(+0,8$ miljard) ook hier in de top vijf van de grootste

groeibestemmingen. Nieuw in de top vijf zijn nu het Verenigd Koninkrijk $(+0,9$ miljard) en Polen ( $+0,4$ miljard) ten koste van Spanje en Italië. Aan de onderkant zijn er ook twee nieuwkomers: China en Japan (in plaats van Marokko en Australië). Het gaat hier echter om relatief kleine afnames. De grootste absolute afname betrof de export naar China ( -65 miljoen euro).

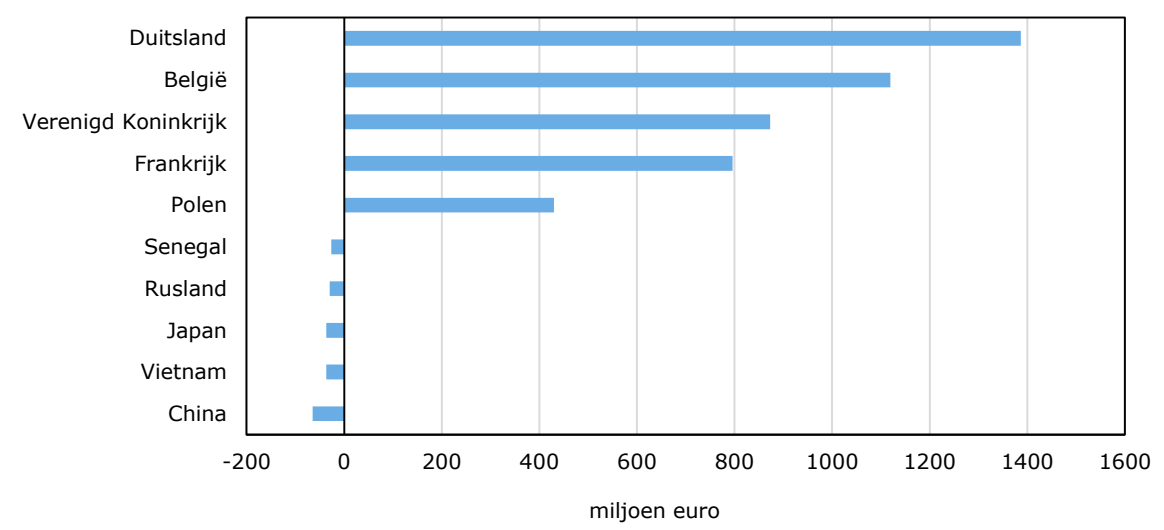

Figuur 3.5 Top vijf stijgers en dalers 2020-2021 in verandering absolute uitvoerwaarde Nederlandse makelij

Bron: CBS tot en met oktober 2021, raming november-december 2021 door CBS en Wageningen Economic Research.

\subsection{Ruim half miljard euro minder import uit VK}

Net als bij de landbouwexport kan ook bij de import een uitsplitsing worden gedaan naar EU en niet-EU. Ook hier zien we dat de handel met EU-landen zich gunstiger heeft ontwikkeld dan met landen buiten de EU (figuur 3.6). De importgroei uit EU-landen wordt geraamd op $13 \%$ en de importgroei uit andere landen op 6\% voor 2021 in vergelijking met 2020. Het aandeel van de 
EU in de totale landbouwimport is daardoor toegenomen van $55,7 \%$ in 2020 tot $57,2 \%$ in 2021 .

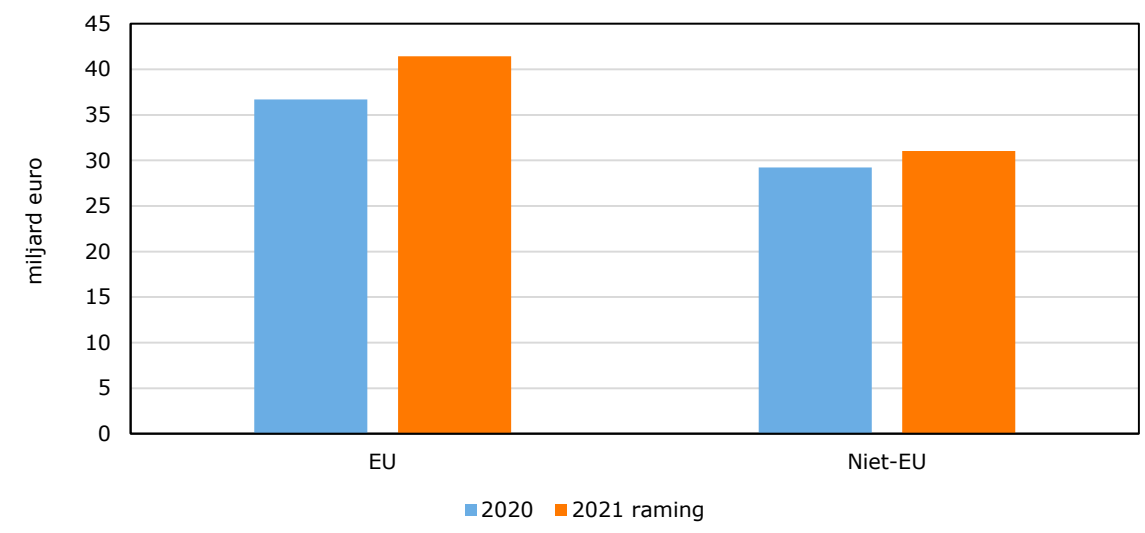

Figuur 3.6 Landbouwimport uit EU en niet-EU

Bron: CBS tot en met oktober 2021, raming november-december 2021 door CBS en Wageningen Economic Research.

De belangrijkste tien leveranciers van landbouwgoederen van 2020 zijn ook de belangrijkste tien van 2021 (zie figuur 3.7). In de volgorde is er een wijziging: het VK is gedaald van een zevende tot een negende positie in de rangschikking, Italië en Polen schuiven beide een plekje omhoog. Het VK is ook enige land in de top tien waarbij de agrarische export naar Nederland fors (met $25 \%$ ) is gedaald in 2021 . Het ligt voor de hand dat de effectieve Brexit per 1 januari 2021 hier een rol speelt (zie verder hoofdstuk 6).

Ook de Amerikaanse landbouwexport naar Nederland kende een afname, maar hier gaat het om slechts $5 \%$ krimp. Bij de overige acht landen is de landbouwexport naar Nederland toegenomen. Dat geldt met name voor Italië $(+19 \%)$, Polen $(+18 \%)$, Brazilië $(+16 \%)$, Oekraïne $(+15 \%)$ en Duitsland $(+13 \%)$ en in mindere mate ook voor Frankrijk $(+10 \%)$, Spanje $(+9 \%)$ en België $(+6 \%)$. Daarmee is Brazilië het enige grote niet-EU-land waaruit Nederland fors meer heeft ingevoerd in 2021 dan in 2020. Het betreft hier met name een forse toename van de invoerwaarde van sojabonen in 2021 in vergelijking met 2020 (met name door prijsstijging), terwijl er in 2020 ook een forse jaar-op-jaargroei was van de invoerwaarde (CBS, 2020). De sterke groei van de waarde van de invoer uit Italië betreft onder andere zuivel, dranken en sierteelt, bij Duitsland granen en natuurlijke vetten en oliën en in het geval van Polen vooral granen.

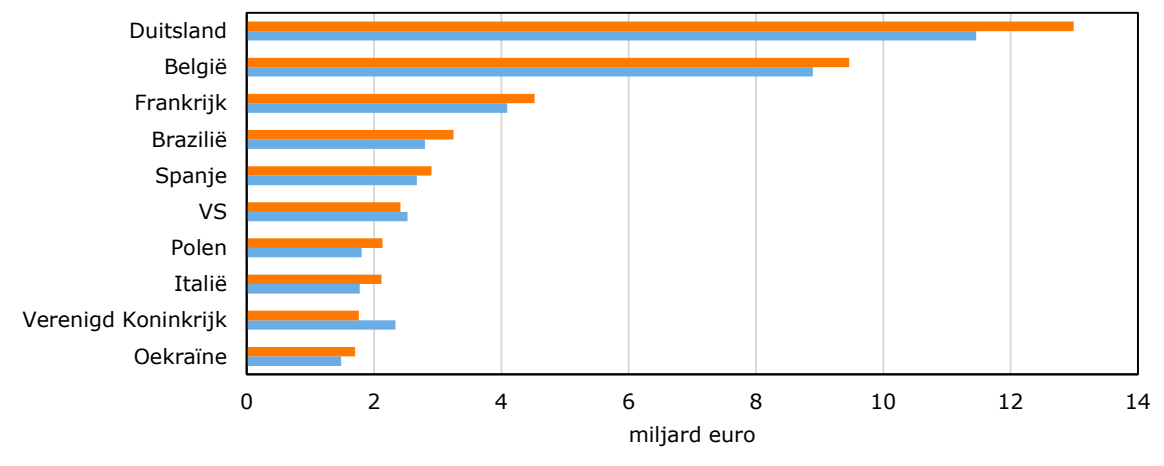

- 2021 raming $=2020$

Figuur 3.7 Top tien herkomstlanden Nederlandse landbouwimport in 2021 Bron: CBS tot en met oktober 2021, raming november-december 2021 door CBS en Wageningen Economic Research.

De groei van de landbouwimport in 2021 wordt geraamd op 6,6 miljard euro. Ruim de helft van de groei komt voort uit de import uit Duitsland, België, Brazilië, Frankrijk en Italië samen; bijna een kwart is te danken aan de importgroei uit alleen Duitsland ( $+1,5$ miljard euro) (figuur 3.8). Ook in deze figuur is Brazilië het enige niet-EU-land dat sterk groeit als leverancier van Nederlandse landbouwgoederen.

Landen waar de importwaarde omlaag is gegaan liggen allemaal buiten de EU. In het geval van Canada, VS, China en Chili gaat het nog om geringe absolute bedragen, van 35 tot 208 miljoen euro krimp. De krimp van de landbouwimport uit het VK is veel groter en het betreft zelfs een groter bedrag (-576 miljoen euro) dan de andere vier landen bij elkaar opgeteld. 


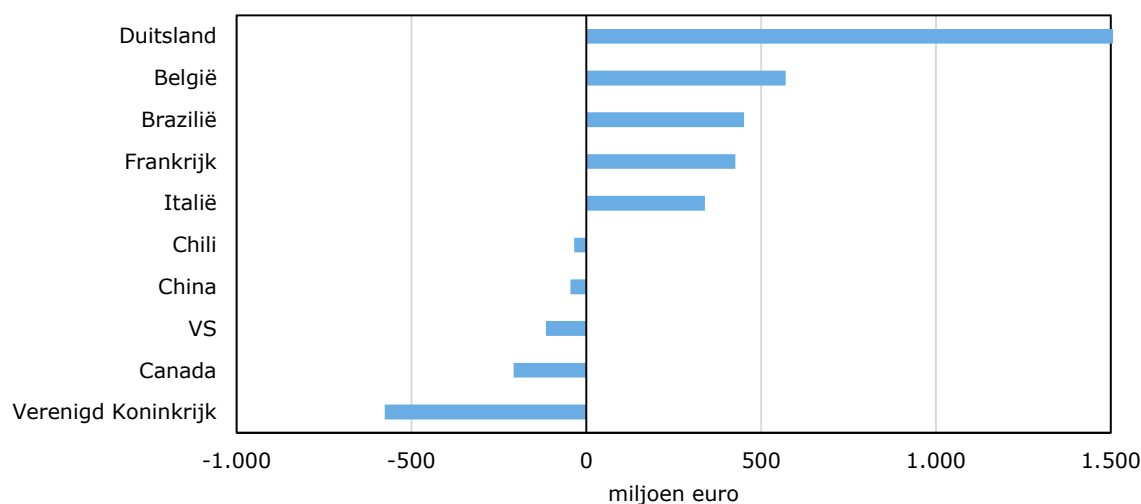

Figuur 3.8 Top vijf stijgers en dalers 2020-2021 in verandering absolute invoerwaarde

Bron: CBS tot en met oktober 2021, raming november-december 2021 door CBS en Wageningen Economic Research.

\subsection{Verdiensten aan export naar China gestegen met $150 \%$}

De berekende landbouwexportverdiensten van paragraaf 2.4 kunnen worden verdeeld naar land van bestemming. Daarbij zijn er enkel cijfers beschikbaar tot en met 2020 (voor 2021 alleen informatie op totaalniveau, zie paragraaf 2.4). De landen in de top tien van belangrijkste bestemmingen in termen van exportverdiensten zijn dezelfde landen die eerder werden getoond als belangrijkste bestemmingen in termen van exportwaarde (zie tabel 3.1), met Zweden in de plaats van Denemarken op plek 10. Aan de export van Duitsland verdiende Nederland bijna 10 miljard euro in 2020 en dat is een toename van $15 \%$ in vergelijking met 2015 . Ook aan de landbouwexport naar België (4,1 miljard euro), het VK (3,8 miljard) en Frankrijk (3,1 miljard) verdient Nederland veel via de landbouwexport. Op enige afstand volgen de andere zes landen.

In de periode 2015-2020 zijn de verdiensten aan de landbouwexport met bestemming China (op plek vijf) het hardst gestegen. Deze zijn met 150\% gegroeid, van 0,75 miljard euro in 2015 tot bijna 1,9 miljard euro in 2020 . Daarbij speelt met name een sterke groei van de export van Nederlands babymelkpoeder en varkensvlees in deze periode (CBS, 2021). China is met afstand de grootste stijger als het gaat om Nederlandse verdiensten aan de landbouwexport. Ook de export naar Polen $(+41 \%)$ is fors belangrijker geworden. Dat gaat het in de eerste plaats om toegenomen verdiensten aan sierteelt en groenten.

Er zijn 4 belangrijke bestemmingen waaraan Nederland slechts minimaal meer is gaan verdienen tussen 2015 en 2020. Dat betreft het Verenigd Koninkrijk $(+1 \%)$, Frankrijk (+3\%), Italië $(+2 \%)$ en Zweden $(+5 \%)$.

Tabel 3.1 Verdiensten aan de export van landbouwgoederen, belangrijkste bestemmingen

\begin{tabular}{lrrr} 
& $\mathbf{2 0 2 0}$ & $\mathbf{2 0 1 5}$ & Toename 2020 t. O.v. 2015 \\
& $\mathbf{m l n}$. euro & mln. euro & \% \\
\hline Duitsland & 9.684 & 8.411 & $\mathbf{1 5 \%}$ \\
\hline België & 4.138 & 3.425 & $\mathbf{2 1 \%}$ \\
\hline Verenigd Koninkrijk & 3.762 & 3.742 & $1 \%$ \\
\hline Frankrijk & 3.115 & 3.012 & $3 \%$ \\
\hline China & 1.869 & 748 & $150 \%$ \\
\hline Italië & 1.451 & 1.428 & $12 \%$ \\
\hline VS & 1.264 & 1.130 & $18 \%$ \\
\hline Spanje & 1.116 & 947 & $41 \%$ \\
\hline Polen & 1.085 & 769 & $5 \%$ \\
\hline Zweden & 837 & 796 &
\end{tabular}

Bron: CBS (waardeketenonderzoek)

Omdat Nederland veel meer goederen exporteert dan enkel landbouwgoederen is het interessant om te kijken naar het landbouwaandeel in het geheel, dus hoeveel procent van de totale goederenexportverdiensten is te danken aan de landbouw? Dan springen het VK en China er echt uit (zie figuur 3.9). De export naar deze twee landen is disproportioneel sterk op de landbouw gericht. Zo betreft $37 \%$ van de verdiensten aan de goederenexport naar het VK landbouwgoederen en bij China is dat zelfs $38 \%$. De 
goederenexport naar de VS (21\%) is veel minder op landbouw gericht en meer op goederen van technologische aard.

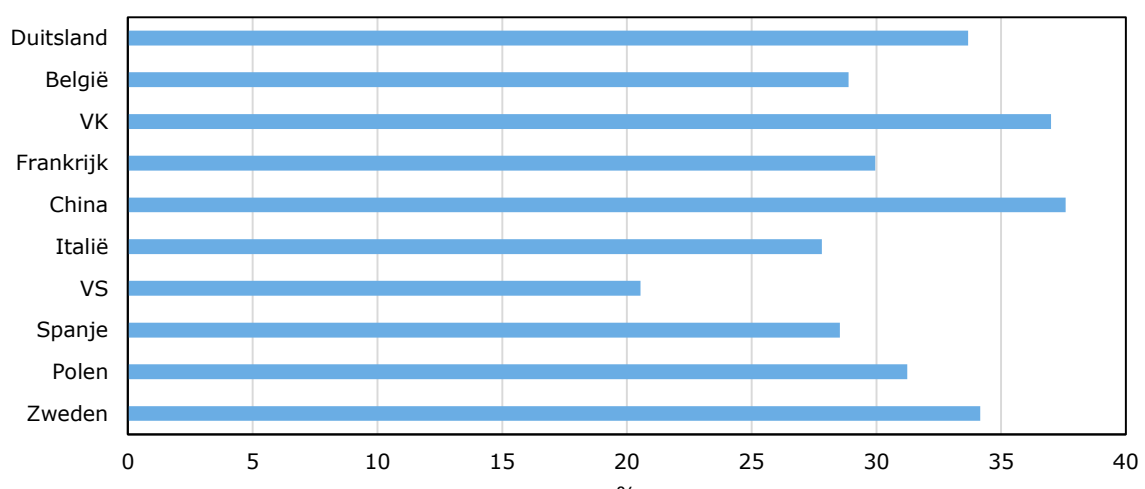

Figuur 3.9 Aandeel landbouw in totale goederenexportverdiensten voor de belangrijkste bestemmingen

Bron: CBS (waardeketenonderzoek). 


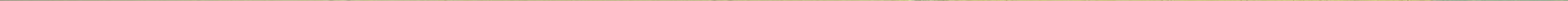




\section{De handel uitgesplitst naar productgroepen}

\subsection{Inleiding}

Dit hoofdstuk beschrijft de ontwikkelingen van de export en import van Nederland in 2021 aan de hand van de 24 landbouwgoederenhoofdstukken en de groep overige landbouwgoederen. Deze laatste groep bestaat uit individuele producten die uit andere hoofdstukken van de handelsstatistieken komen, maar wel tot de landbouw worden gerekend. De landbouwgoederenhoofdstukken, veelal gegroepeerd naar productgroep, zijn hieronder gerangschikt naar afnemend aandeel in de exportwaarde, uitgezonderd de overige

landbouwgoederen die niet in de eerste 24 hoofdstukken vallen. Deze worden als laatste beschreven. De landbouwgerelateerde goederen zoals kasmaterialen en landbouwmachines komen in het volgende hoofdstuk aan bod.

Met een aandeel van ruim $11 \%$ in de landbouwexportwaarde was sierteelt het meest uitgevoerde exportproduct in 2021. Vlees, zuivel en eieren, groenten en fruit zijn ook productgroepen die veel werden geëxporteerd. De top vijf is goed voor $42 \%$ van de totale landbouwexport. Bij de import was het aandeel van de natuurlijke oliën en vetten het hoogst, gevolgd door fruit, dranken, oliehoudende zaden en vruchten, zuivelproducten en cacao. Samen zijn deze productgroepen goed voor $39 \%$ van de totale import van landbouwgoederen. In bijlage 4 zijn gedetailleerde lijsten van productgroepen en landen te vinden.

\subsection{Sierteeltproducten: sterke toename export- en importwaarde}

In deze paragraaf komen onder andere bloembollen, boomkwekerijproducten, snijbloemen en (kamer) planten aan bod. De export van sierteeltproducten nam in 2021 met ongeveer $25 \%$ toe tot 12 miljard euro (tabel 4.1). Van de export ging 28\% naar Duitsland, 14\% naar het VK en 9\% naar Frankrijk. De exportwaarde naar Duitsland en het VK steeg met respectievelijk $23 \%$ en $44 \%$. Ook naar Frankrijk steeg de exportwaarde met $23 \%$. Van de totale waarde aan geëxporteerde sierteeltproducten was $87 \%$ van Nederlandse makelij.

De extreme toename van de exportwaarde kende verschillende redenen. Allereerst was de toename een correctie op de corona-uitbraak, waardoor de bloemenveilingen in 2020 genoodzaakt waren aanvoerrestricties op te leggen aan aanvoerders. Hierdoor werd de aanvoerketen van bloemen sterk ontwricht. Ook moesten bloemenwinkels dicht. Hoewel de sector in de rest van 2020 de schade aardig had ingehaald, leidde het ertoe dat dit jaar de exportwaarde kon toenemen. Ten tweede steeg de vraag naar bloemen en planten. Mensen werken veel thuis en zijn positief over groen op de thuiswerkplek (Bloemenbureau, 2021). Bloemen en planten verbeteren ook het binnenklimaat (RIVM, 2021). Bovendien kan men het geld niet uitgeven aan bijvoorbeeld vakanties en blijft er geld over voor dergelijke aankopen. Door de coronaomstandigheden zijn er ook meer gelegenheden tot het geven van bloemen. Ook dat stimuleert de verkoop. Ten derde neemt de importhoeveelheid niet veel toe door beperkte vluchtbewegingen van passagiersvliegtuigen. Op de bloemenveiling komt dit aanbod, inclusief de Nederlandse productie, samen. Omdat de vraag daar harder stijgt dan het aanbod, nemen de prijzen sterk toe. Heel veel bloemen worden daarna weer geëxporteerd, wat ook de exportwaarde doet toenemen. Het aantal vluchten zit nog lang niet op het niveau van voor de uitbraak van de coronacrisis (Schiphol, 2021). En deze passagiersvluchten worden veel gebruikt om ook bloemen naar Nederland te vervoeren. Ten slotte was het een redelijk stabiele zomer zonder al te veel warme perioden. Ook de export van bomen en bollen zat in de lift.

Nederland importeert uit Duitsland en België ook veel sierteeltproducten. Deze stroom bestaat vooral uit snijbloemen die via de Belgische en Duitse luchthavens uit andere delen van de wereld ingevlogen worden. Afhankelijk van de beschikbaarheid van vrachtruimte, tarieven, beschikbare slots, kiest 
men voor luchthavens als Schiphol, Frankfurt, Luik of Brussel om de producten naar de Europese tussenhandel te vervoeren. Vervolgens worden deze naar Nederlandse veilingen getransporteerd om daar verkocht te worden. Daarnaast is er in de buurlanden ook veel kweek van perkgoed en boomkwekerijproducten. Door toegenomen vraag in Nederland werd meer geïmporteerd uit de buurlanden. Zo kwamen er uit Duitsland meer kamer- en tuinplanten en droog- en geïmpregneerde bloemen en steeg de importwaarde van snijbloemen uit Kenia. Uit België kwam een combinatie van buiten- en kamerplanten, bomen en bloemen naar Nederland.

Tabel 4.1 Nederlandse handel in sierteeltproducten (GN-06)

\begin{tabular}{|c|c|c|}
\hline \multirow{2}{*}{ Totale exportwaarde (mld. euro) } & \multicolumn{2}{|c|}{2021 (raming) mutatie t.o.v. 2020} \\
\hline & 12,0 & $25,2 \%$ \\
\hline Waarvan van Nederlandse makelij & $87 \%$ & \\
\hline Aandeel in de landbouwexport & $11,5 \%$ & \\
\hline Totale importwaarde (mld. euro) & 2,7 & $20,6 \%$ \\
\hline Aandeel in de landbouwimport & $3,7 \%$ & \\
\hline \multicolumn{3}{|c|}{ Belangrijkste exportbestemmingen ( $\mathrm{m} / \mathrm{n}$. euro) } \\
\hline Duitsland & 3.372 & 23 \\
\hline Verenigd Koninkrijk & 1.674 & 44 \\
\hline Frankrijk & 1.111 & 23 \\
\hline \multicolumn{3}{|c|}{ Belangrijkste herkomstlanden import (mln. euro) } \\
\hline Duitsland & 418 & 22 \\
\hline Kenia & 377 & 14 \\
\hline België & 354 & 14 \\
\hline
\end{tabular}

Bron: CBS tot en met oktober 2021, raming november - december 2021 door WUR en CBS.

\subsection{Vlees: export groeit 6,5\%, import ruim 3\%}

Nederland exporteerde in 2020 voor 9,1 miljard euro export aan vlees en eetbare slachtbijproducten, dat is 6,5\% meer dan in 2020 (tabel 4.2). De importwaarde steeg meer dan 3\%. Uit zowel Duitsland, België als Polen importeerde Nederland 7\% meer waarde aan vlees dan vorig jaar. De exporttoename van ruim $6,5 \%$ was niet terug te vinden in de belangrijkste exportbestemmingen. De exportwaarde naar Duitsland steeg met $1 \%$. Naar het Verenigd Koninkrijk daalde de exportwaarde met 1\%, naar China met $10 \%$. Naar Zuid-Korea (varken), Frankrijk (rund en kip), Denemarken (varken) en België (varken) steeg de exportwaarde wel.

De drie belangrijkste vleessoorten zijn vlees van runderen en kalveren, varkensvlees en kippenvlees. Afhankelijk van prijszetting en beschikbaarheid hebben deze vleessoorten globaal een aandeel in de export van 25 tot 30\%. De resterende $15-20 \%$ bestaat uit vlees van andere dieren zoals schapen, geiten, konijnen en paarden of uit restproducten.

Na problemen met de varkenspest is de productie van varkensvlees in China en omringende landen weer toegenomen. Hierdoor daalde de vraag vanuit deze landen naar varkensvlees uit Europa, waaronder van Nederlandse makelij. Bovendien waarde de Afrikaanse varkenspest bij wilde zwijnen in Duitsland en Polen nog altijd rond, waardoor er restricties golden voor exporten naar bepaalde landen. De vraag naar varkensvlees is hierdoor afgenomen en de afzetmarkt van varkensvlees in Europa is te klein voor de huidige Europese productie (ondanks het feit dat het aantal gehouden varkens in Nederland lager was dan in 2021). Dit zet druk op de prijzen van varkensvlees, waardoor de exportwaarde van varkensvlees sterk daalde.

Kippenvlees kent, dankzij de wat meer geopende restaurants en out-ofhomekanalen zoals bedrijfs- en schoolkantines en catering, een wat beter exportjaar dan 2020. Maar het verschil met vorig jaar is minimaal. Hoewel de prijzen wat beter waren, was het exportvolume kleiner.

De export van rundvlees nam wel sterker toe door gedeeltelijke openstelling van horeca en out-of-homekanalen. Zowel volume als prijzen lagen op een hoger niveau.

Nederland importeerde in 2021 voor 3,7 miljard euro aan vlees, een toename van ruim $3 \%$ ten opzichte van 2020. Duitsland, België en Polen waren goed voor $50 \%$ van de totale waarde aan vleesimport in Nederland. De import uit Duitsland en België steeg in volume, maar de prijzen lagen onder het niveau van een jaar eerder. Bij de import uit Polen, vooral kippenvlees, was zowel de prijs als het volume hoger. Uit België steeg de import van kip en rundvlees. Uit Duitsland kwam vooral meer varkensvlees. 
Tabel 4.2 Nederlandse handel in vlees (GN-02)

\begin{tabular}{lrr} 
& 2021 (raming) & mutatie t.o.v. 2020 \\
Totale exportwaarde (mld. euro) & $\mathbf{9 , 1}$ & $\mathbf{6 , 5 \%}$ \\
\hline Waarvan van Nederlandse makelij & $89 \%$ & \\
\hline Aandeel in de landbouwexport & $8,6 \%$ & $\mathbf{3 , 2 \%}$ \\
\hline Totale importwaarde (mld. euro) & $\mathbf{3 , 7}$ & \\
\hline Aandeel in de landbouwimport & & 1 \\
\hline Belangrijkste exportbestemmingen (mln. euro) & 1.728 & -1 \\
\hline Duitsland & 1.068 & -10 \\
\hline Verenigd Koninkrijk & 871 & 7 \\
\hline China & & 7 \\
\hline Belangrijkste herkomstlanden import (mln. euro) & 1.006 & 7 \\
\hline Duitsland & 488 & 378 \\
\hline België & & \\
\hline Polen & & \\
\hline
\end{tabular}

Bron: CBS tot en met oktober 2021, raming november - december 2021 door WUR en CBS.

\subsection{Zuivel en eieren: import kent sterkere groei} dan export

In 2021 bedroeg de export van zuivel en eieren 8,7 miljard euro, 5\% meer dan in 2020 (tabel 4.3). De importwaarde bedroeg in 2021 nagenoeg de helft van de exportwaarde, namelijk 4,3 miljard euro. De groei van de import bedroeg ruim $9 \%$. Absoluut gezien steeg de export echter harder dan de import.

De exportwaarde van kaas steeg met $4 \%$, de exportwaarde van eieren steeg met $2 \%$ terwijl andere producten uit deze productgroep zoals melk, weiproducten en boter gezamenlijk met $6 \%$ toenamen.

De export van eieren naar Duitsland nam met $5 \%$ toe. Vooral door meer volume te exporteren tegen lagere prijzen. Duitsland is en blijft, met ruim $80 \%$ van de ei-export, de belangrijkste bestemming voor eieren en eiproducten. De kaasexport naar Duitsland groeide met nog geen 2\%. Er ging meer Gouda kaas en minder Edammer naar Duitsland. Van andere producten zoals boter, room, wei en yoghurt steeg de exportwaarde met zo'n $6 \%$. Per saldo was er een toename van $4 \%$. De exportwaarde naar België groeide met
$8 \%$. Dit kwam met name door een toename in de uitvoerwaarde van boter, room, wei en yoghurt met $16 \%$. De kaasexport groeide niet en de relatief lage ei-export steeg met $11 \%$. De groei naar Frankrijk was even groot bij kaas als bij de groep boter, room, wei en yoghurt.

De (beperkte) importwaarde van eieren daalde met $12 \%$ terwijl die van de meer omvangrijke kaasimport met ongeveer $4 \%$ toenam. Van de andere producten steeg de import het sterkst, met $14 \%$. Duitsland is met een aandeel van $38 \%$ het belangrijkste herkomstland. Samen met België en Ierland zijn deze drie landen goed voor twee derde van de totale import in 2021. De import uit Duitsland groeide vooral door de overige groep producten zoals room, wei en boter $(+12 \%)$. De kaas export nam $5 \%$ toe, terwijl de importwaarde van eieren uit Duitsland met $7 \%$ toenam. Verder valt de groe van de import van Ierland op, de stijging van $24 \%$ is vooral toe te schrijven aan producten zoals room, wei en boter. Vooral de import van boter nam toe. Deze groep producten vertegenwoordigt gezamenlijk ook de grootste handelswaarde uit Ierland. Procentueel steeg de kaasimport harder. Cheddar is een van de goederen waarvan, via deze route, de import sterk toenam.

Tabel 4.3 Nederlandse handel in zuivel en eieren (GN-04)

\begin{tabular}{|c|c|c|}
\hline Totale exportwaarde (mld. euro) & $\begin{array}{r}2021 \text { (raming) } \\
8,7\end{array}$ & $\begin{array}{r}2020 \\
5,0 \% \\
\end{array}$ \\
\hline Waarvan van Nederlandse makelij & $81 \%$ & \\
\hline Aandeel in de landbouwexport & $8,3 \%$ & \\
\hline Totale importwaarde (mld. euro) & 4,3 & $9,1 \%$ \\
\hline Aandeel in de landbouwimport & $6,0 \%$ & \\
\hline \multicolumn{3}{|c|}{ Belangrijkste exportbestemmingen ( $\mathrm{m} / \mathrm{n}$. euro) } \\
\hline Duitsland & 2.630 & 4 \\
\hline België & 1.210 & 8 \\
\hline Frankrijk & 839 & 4 \\
\hline \multicolumn{3}{|c|}{ Belangrijkste herkomstlanden import (mIn. euro) } \\
\hline Duitsland & 1.662 & 9 \\
\hline België & 882 & 5 \\
\hline Ierland & 440 & 24 \\
\hline
\end{tabular}

Bron: CBS tot en met oktober 2021, raming november - december 2021 door WUR en CBS. 


\subsection{Aardappelen en groenten: voorzichtige groei export}

De waarde van de export van kas- en vollegrondsgroenten, aardappelen en uien bedroeg 7,2 miljard euro in 2021 , bijna $2 \%$ meer dan in 2020 (tabel 4.4). De import nam toe met $8,4 \%$ tot 2,8 miljard euro. Tomaten, paprika's en komkommers zijn de belangrijkste exportgroenten.

De exportwaarde van tomaten nam toe door hogere prijzen. Dit werd mede veroorzaakt door een lager areaal en lagere productie in Nederland, bij een herstellende vraag door de gedeeltelijke heropening van de horeca en foodservice. De groei kwam wel pas laat in het jaar tot stand. Voor paprika's, komkommers en zeker aubergines waren de prijzen lager. Bij komkommers kon een groter volume worden afgezet.

De export van groenten is met name gericht op de buurlanden. In 2021 gaat ongeveer 57\% naar Duitsland, het VK en België. Met Frankrijk meegerekend is dit percentage rond de $60 \%$. Bij de export naar deze landen spelen veelal bovengenoemde producten een rol. Naar Duitsland nam ook de export van uien, wortelen en prei toe. Naar België steeg de export van poot- en consumptieaardappelen en van zoete aardappelen en uien.

Het grootste deel van de geïmporteerde groenten komt uit Europa. Spanje blijft, ondanks een daling van $2 \%$, het belangrijkste herkomstland (23\%). Andere belangrijke herkomstlanden zijn België (18\%), Duitsland (15\%) en Frankrijk (6\%).

Uit Spanje komen met name groenten die door seizoenverschillen of klimatologische omstandigheden niet in Noord-Europa geteeld kunnen worden of dan minder ruim voorradig zijn. Zo komen vooral tomaten, paprika's en komkommer naar Nederland in de winterperiode. Dit jaar groeide de importwaarde van tomaten uit Spanje, maar daalde van komkommers. Uiteraard is dit afgezet tegen het verstoorde (corona) jaar 2020. België en Duitsland voerden meer uit naar Nederland. Voor België ging het niet alleen om een sterke groei van de uitvoer van tomaten, maar waren het diverse producten (paprika, ui, zoete aardappel, prei) die voor de toename zorgden. De groei met $16 \%$ van de Duitse uitvoer naar Nederland is vooral een (volume)toename van aardappelen, alhoewel ook hier meerdere producten de groei droegen.

Tabel 4.4 Nederlandse handel in groente (GN-07)

\begin{tabular}{lrr} 
& $\mathbf{2 0 2 1}$ (raming) & mutatie t.o.v. 2020 \\
\hline Totale exportwaarde (mld. euro) & $\mathbf{7 , 2}$ & $\mathbf{1 , 9 \%}$ \\
\hline Waarvan van Nederlandse makelij & $82 \%$ & \\
\hline Aandeel in de landbouwexport & $6,8 \%$ & $\mathbf{8 , 4 \%}$ \\
\hline Totale importwaarde (mld. euro) & $\mathbf{2 , 8}$ & \\
\hline Aandeel in de landbouwimport & $3,8 \%$ & 6 \\
\hline Belangrijkste exportbestemmingen (mln. euro) & 2.540 & 9 \\
\hline Duitsland & 814 & -5 \\
\hline België & 801 & -2 \\
\hline Verenigd Koninkrijk & & 11 \\
\hline Belangrijkste herkomstlanden import (mln. euro) & 634 & 16 \\
\hline Spanje & 507 & \\
\hline België & 423 & \\
\hline Duitsland & & \\
\hline
\end{tabular}

Bron: CBS tot en met oktober 2021, raming november - december 2021 door WUR en CBS.

\subsection{Fruit: import en export stabiel}

Avocado's, druiven, bananen, (blauwe) bessen, mango's en peren zijn de belangrijkste exportproducten bij de groep fruit. De waarde van de export van fruit bedroeg 7 miljard euro in 2021 en is ongeveer gelijk aan vorig jaar. De importwaarde nam beperkt af met 1,4\% (tabel 4.5 ).

Het merendeel van de export betreft wederuitvoer. Slechts $24 \%$ van de export is van Nederlandse makelij. Duidelijk is dat Nederland een distributiefunctie heeft naar de rest van Europa. Omdat andere productgroepen veelal een hogere exportwaarde noteerden in 2021, is het aandeel in de totale export gedaald met een half procentpunt naar 6,7\%.

De export naar Duitsland bleef ten opzichte van 2020 gelijk, maar met een aandeel van $36 \%$ beïnvloedt dat de totale ontwikkeling sterk. België en 
Frankrijk kenden wel een toename, vooral door meer volume van de export van druiven. Ook de afzet van kokosnoten naar België deed het goed. Met een volumegroei van blauwe bessen en bananen steeg de export naar België in totaal met 7\%. Naar Frankrijk werd 5\% meer waarde aan fruit afgezet. De sterkste groei werd genoteerd voor guaves en mango's, avocado's, citrusvruchten en appels: vooral door volumegroei nam de export toe. Alleen appels konden tegen betere prijzen worden afgezet. Nederland zet dit fruit voornamelijk af in de omringende landen. In 2021 werd 55\% van de export van fruit in Duitsland, Frankrijk en België afgezet, 88\% blijft binnen de EU-27.

De importgroei was vorig jaar groot. Dit jaar is er een kleine negatieve correctie waarneembaar. Deze daling zat niet bij de landen uit de top drie, maar landen als België, het VK, Costa Rica (bananen), Chili en Mexico (avocado) lieten wel kleine waardedalingen zien. De toename van de importwaarde uit Zuid-Afrika kwam door een hoger volume tegen lagere prijzen van druiven. De importwaarde van pruimen uit dit land steeg ook. De toename uit Peru had te maken met een groter volume tegen lagere prijzen. Avocado's en druiven stegen qua invoerwaarde het meest. Uit Spanje nam de import van blauwe bessen sterk toe. Bij andere producten daalde de importwaarde juist. Per saldo was de importwaarde nagenoeg gelijk.

Tabel 4.5 Nederlandse handel in fruit (GN-08)

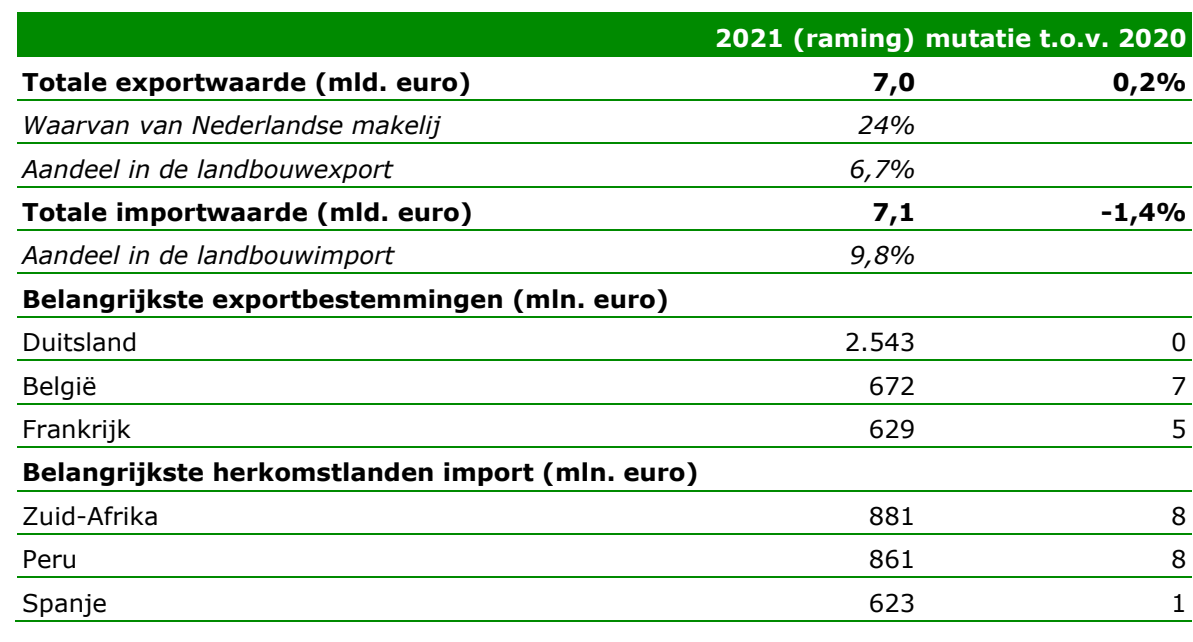

Bron: CBS tot en met oktober 2021, raming november - december 2021 door WUR en CBS.

\subsection{Dranken: groei export en import}

De exportwaarde van dranken was met 6,6 miljard euro in $202110 \%$ hoger dan in 2020 (tabel 4.6). De belangrijkste exportproducten zijn bier, mineraalwater, sterke dranken en andere niet-alcoholische dranken. Ook ethylalcohol (al dan niet) gedenatureerd, vloeistoffen die ook bruikbaar zijn voor ontsmettings- en reinigingsmiddelen, vallen onder deze handelsgroep.

Hoewel de exportwaarde naar nagenoeg alle Europese landen toenam, door zowel prijs- als volumestijgingen, was de export naar de VS, de belangrijkste exportbestemming, lager dan een jaar eerder. Vooral bier kende een lagere exportwaarde. De afzet werd dichter bij huis gezocht en gevonden in onder andere Duitsland en het VK. Naast bier werd ook meer ethylalcohol, whisky, maar ook niet alcoholische dranken naar Duitsland geëxporteerd. Naar het VK was de toename, naast bier, ook te danken aan groei van de likeuren en op soja-gebaseerde vloeistoffen.

Tabel 4.6 Nederlandse handel in dranken (GN-22)

\begin{tabular}{lrr} 
& 2021 (raming) & mutatie t.o.v. $\mathbf{2 0 2 0}$ \\
Totale exportwaarde (mld. euro) & $\mathbf{6 , 6}$ & $\mathbf{1 0 , 0 \%}$ \\
\hline Waarvan van Nederlandse makelij & $69 \%$ & \\
\hline Aandeel in de landbouwexport & $6,3 \%$ & $\mathbf{1 0 , 7 \%}$ \\
\hline Totale importwaarde (mld. euro) & $\mathbf{5 , 0}$ & \\
\hline Aandeel in de landbouwimport & $6,9 \%$ & -9 \\
\hline Belangrijkste exportbestemmingen (mln. euro) & 822 & 10 \\
\hline VS & 802 & 15 \\
\hline Duitsland & 769 & 23 \\
\hline Verenigd Koninkrijk & & 16 \\
\hline Belangrijkste herkomstlanden import (mln. euro) & 975 & 19 \\
\hline België & 912 & \\
\hline Duitsland & 770 & \\
\hline Frankrijk & & \\
\hline
\end{tabular}

Bron: CBS tot en met oktober 2021, raming november - december 2021 door WUR en CBS. 
In 2021 bedroeg de waarde van de import van dranken 5 miljard euro, ruim $10 \%$ hoger dan in 2020. Bij de import zijn de belangrijkste herkomstlanden België (20\%), Duitsland (18\%) en Frankrijk (15\%). De verschillen ten opzichte van vorig jaar waren voor de top drie herkomstlanden groter dan voor de totale groei. Uit België nam vooral de import van ethylalcohol en bier toe. Uit Duitsland nam de wijnimport sterk toe. Ook ethylalcohol werd meer uit Duitsland betrokken. Voor België ging het om meer volume, voor Duitsland is de stijging van de importwaarde meer het gevolg van een hogere prijs. Uit Frankrijk werd meer wijn en champagne geïmporteerd.

\subsection{Oliën en vetten: sterke toename import en export}

De export van oliën en vetten is in 2021 bijna $22 \%$ hoger dan een jaar eerder (tabel 4.7). De import groeide met ongeveer hetzelfde percentage, namelijk $21 \%$. De oliën- en vettenindustrie is toeleverancier aan vele andere sectoren zoals de diervoederindustrie, biodieselsector, oleo-chemicaliën en de levensmiddelenbranche. Belangrijke producten in dit hoofdstuk zijn onder andere palmolie en margarine.

De stijging van de exportwaarde kwam vooral door de gestegen prijzen van de verhandelde goederen in deze productgroep. De volumes namen af. Duitsland (31\%) en België (20\%) hebben het grootste aandeel in de export, gevolgd door het VK (7\%) en Frankrijk (6\%). Vooral de export naar onze buurlanden steeg. De exportwaarde naar Duitsland nam toe door meer palmolie, zonnebloemolie, kokosolie en yellow grease. Bij al deze producten steeg de exportprijs, bij palmolie en kokosolie nam ook het volume toe. Richting België was het ook vooral een prijseffect dat de exportwaarde liet toenemen. Met name van kool- en raapzaadolie steeg de exportwaarde naar België, als gevolg van door prijseffecten. Ditzelfde was het geval bij zonnebloemolie- en palmolie.

Kijkend naar de belangrijkste herkomstlanden in 2021 valt de sterkere stijging in de groei van de exportwaarde van de top drie landen op. Met name uit landen als Papoea-Nieuw-Guinea, Honduras, Filipijnen en Guatemala (onderdeel van de groep overige niet-EU-landen) groeide de importwaarde. Uit de eerste twee landen nam de importwaarde van palmolie toe door hogere inkoopprijzen. Bij de Filipijnen ging het om prijsstijgingen van kokosolie. Alleen bij Guatemala was er naast prijsstijgingen ook een toename van het importvolume van palmolie. Ook de toename van de import uit Duitsland betrof voor het grootste deel prijsstijgingen van al dan niet geraffineerde koolen raapzaadolie, daarnaast was er sprake van groei van het volume.

Bij het produceren van koolzaadolie komt pulp vrij dat onder andere gebruikt wordt voor het maken van perskoeken voor veevoer (zie ook paragraaf 4.9). Verder wordt de pulp gebruikt bij het maken van plantaardige margarine en sauzen en voor biobrandstof. Palmolie kan ook worden gebruikt voor frituurolie en de productie van koekjes, sauzen en margarine. Daarnaast kan het ook als ingrediënt dienen voor biobrandstof. Ook dient palmolie als grondstof bij de productie van shampoo, zeep, cosmetica en diervoeding.

Tabel 4.7 Nederlandse handel in natuurlijke vetten en oliën (GN-15)

\begin{tabular}{lrr} 
& $\mathbf{2 0 2 1}$ (raming) & mutatie t.o.v. 2020 \\
Totale exportwaarde (mld. euro) & $\mathbf{5 , 7}$ & $\mathbf{2 2 , 0 \%}$ \\
\hline Waarvan van Nederlandse makelij & $70 \%$ & \\
\hline Aandeel in de landbouwexport & $5,5 \%$ & $\mathbf{2 0 , 9 \%}$ \\
\hline Totale importwaarde (mld. euro) & $\mathbf{7 , 1}$ & \\
\hline Aandeel in de landbouwimport & $9,8 \%$ & 19 \\
\hline Belangrijkste exportbestemmingen (mln. euro) & 1.753 & 27 \\
\hline Duitsland & 1.139 & -7 \\
\hline België & 376 & 43 \\
\hline Verenigd Koninkrijk & 1.296 & 37 \\
\hline Belangrijkste herkomstlanden import (mln. euro) & 1.289 & 19 \\
\hline Overig niet-EU & 983 & \\
\hline Duitsland & & \\
\hline Maleisië & & \\
\hline
\end{tabular}

Bron: CBS tot en met oktober 2021, raming november - december 2021 door WUR en CBS.

\subsection{Overige voeding: toename export en import}

De goederengroep 'overige voeding' is zeer divers. Het gaat onder andere om soepen, sauzen, ijsjes en samengestelde voedselbereidingen. De export van overige voedingsproducten steeg in 2021 tot 5,5 miljard euro, een stijging 
van ruim $10 \%$ ten opzichte van 2020 (tabel 4.8). Van de export ging 17\% naar Duitsland, naar België nam het aandeel toe tot $10 \%$, gelijk aan dat van het VK. De exportgroei naar Duitsland is vooral toe te schrijven aan een hogere exportwaarde van sausen, ijs en proteïneconcentraten. Van de totale waarde aan geëxporteerde overige voeding is ongeveer $69 \%$ van Nederlandse makelij.

De import van overige voedingsproducten bedroeg 3,1 miljard euro in 2021, ruim $12 \%$ meer dan in 2020. De belangrijkste drie herkomstlanden waren Duitsland (19\%), België (16\%) en de VS (10\%). Vooral de import uit België steeg, door een toename van de prijs voor de geïmporteerde goederen.

Tabel 4.8 Nederlandse handel in overige voeding (GN-21)

\begin{tabular}{|c|c|c|}
\hline Totale exportwaarde (mld. euro) & $\begin{array}{r}2021 \text { (raming) } \\
5,5\end{array}$ & $\begin{array}{r}\text { v. } 2020 \\
10,3 \%\end{array}$ \\
\hline Waarvan van Nederlandse makelij & $69 \%$ & \\
\hline Aandeel in de landbouwexport & $5,2 \%$ & \\
\hline Totale importwaarde (mld. euro) & $\mathbf{3 , 1}$ & $12,2 \%$ \\
\hline Aandeel in de landbouwimport & $4,3 \%$ & \\
\hline \multicolumn{3}{|c|}{ Belangrijkste exportbestemmingen (mIn. euro) } \\
\hline Duitsland & 929 & 7 \\
\hline België & 571 & 22 \\
\hline Verenigd Koninkrijk & 553 & -4 \\
\hline \multicolumn{3}{|c|}{ Belangrijkste herkomstlanden import (mln. euro) } \\
\hline Duitsland & 575 & 4 \\
\hline België & 485 & 11 \\
\hline VS & 320 & -1 \\
\hline
\end{tabular}

Bron: CBS tot en met oktober 2021, raming november - december 2021 door WUR en CBS.

\subsection{Resten van de voedselindustrie, veevoer: toename export}

De goederengroep 'resten uit de voedselindustrie en veevoer' is een diverse groep producten en bevat onder meer sojaschroot, zonnebloemzaadschroot, honden- en kattenvoer, premixes voor veevoer en palmpitschilfers. De exportwaarde van deze groep producten steeg in 2021 met ruim $8 \%$ ten opzichte van 2020 (tabel 4.9). Duitsland (24\%), België (21\%) en het VK waren de belangrijkste exportbestemmingen, samen goed voor een aandeel van $53 \%$ in de totale export van deze groep. Veel van de exportwaarde komt van Nederlandse bodem omdat er veel verwerkende industrie in Nederland is. Met name naar België groeide de exportwaarde, vooral door meer uitvoer van veevoederproducten.

In 2021 bedroeg de importwaarde van resten uit de voedselindustrie en veevoer 3,5 miljard euro, een kleine $10 \%$ stijging ten opzichte van 2020 . De waardetoename was procentueel groter uit Duitsland en België. De import vanuit Duitsland groeide door een toename van de invoer van kattenvoer, perskoeken en bietenpulp. De importwaarde uit België steeg ook

bovengemiddeld. Met name een toename van bierborstel (zowel in volume als in prijs) zorgde voor deze toename. Over het algemeen stegen de voerkosten dit jaar sterk. De import uit Brazilië bleef in evenwicht bij lagere volumes tegen hogere prijzen.

Tabel 4.9 Nederlandse handel in resten van de voedselindustrie, veevoer (GN-23)

\begin{tabular}{lrr} 
& 2021 (raming) & mutatie t.o.v. 2020 \\
Totale exportwaarde (mld. euro) & $\mathbf{5 , 4}$ & $\mathbf{8 , 3 \%}$ \\
\hline Waarvan van Nederlandse makelij & $72 \%$ & \\
\hline Aandeel in de landbouwexport & $5,1 \%$ & $\mathbf{9 , 9 \%}$ \\
\hline Totale importwaarde (mld. euro) & $\mathbf{3 , 5}$ & \\
\hline Aandeel in de landbouwimport & $4,8 \%$ & 2 \\
\hline Belangrijkste exportbestemmingen (mln. euro) & 1.308 & 10 \\
\hline Duitsland & 1.159 & 5 \\
\hline België & 435 & 13 \\
\hline Verenigd Koninkrijk & & 1 \\
\hline Belangrijkste herkomstlanden import (mln. euro) & 782 & 15 \\
\hline Duitsland & 622 & \\
\hline Brazilië & 508 & \\
\hline België & & \\
\hline
\end{tabular}

Bron: CBS tot en met oktober 2021, raming november - december 2021 door WUR en CBS. 


\subsection{Bereidingen van graan, meel en melk: meer import, minder export}

Onder bereidingen van graan, meel en melk valt een diverse groep producten, zoals allerlei voedingsbereidingen voor baby's en jonge kinderen, koekjes, pizza's en pastaproducten. In 2021 bedroeg de totale exportwaarde circa 5 miljard euro, een afname van bijna 5\% ten opzichte van 2020 (tabel 4.10). De import steeg met $5,4 \%$ tot 2,6 miljard euro.

Bij de export van deze groep is één product dominant, babymelkpoeder. In 2021 daalde de export hiervan naar China sterk, met ruim 20\%. Logistieke uitdagingen en minder vraag, door lagere geboortecijfers in China, leidden tot een lagere export na een lange periode van groei. Ook is er meer regionale concurrentie. FrieslandCampina, een van de producenten, schaalde hierdoor productiecapaciteit af (Boerenbusiness.nl, 2021). De 19\% groei van de exportwaarde naar Duitsland werd gerealiseerd door een breed productenpakket. Vooral bakkerswaren, wafels, pizza's en brood werden meer geëxporteerd. Volumetoename voeren hierbij de boventoon. België kende een hogere exportwaarde door een combinatie van prijsverhogingen en volumegroei. Met name meer pizza en quiches werden naar onze zuiderburen geëxporteerd. Maar, net als naar Duitsland, was de toename toe te schrijven aan een breed productenpakket.

De belangrijkste herkomstlanden voor de import van bereidingsproducten van graan, meel en melk waren Duitsland, België, en Frankrijk, samen goed voor $58 \%$ van de import. De toename van ruim $5 \%$ was vooral een herstel ten opzichte van vorig jaar. De import van 2,6 miljard euro ligt inmiddels weer nagenoeg op het niveau van 2019

De groei van de import uit Duitsland is toe te schrijven aan pizza, quiches en andere bakkerswaren, meel- en moutextracten en broodproducten. Uit België kwamen vooral meer geëxtrudeerde en geëxpandeerde producten. Ook nam de import uit de groep producten 'fruittaart, krenten- en rozijnenbrood, panettone, meringues, kerststollen, croissants en andere bakkerswaren' toe.

Uit beide landen is het echter een breed productenpakket dat bijdraagt aan de toename.
Tabel 4.10 Nederlandse handel in bereidingen van graan, meel en melk (GN-19)

\begin{tabular}{|c|c|c|}
\hline & 2021 (raming) & v. 2020 \\
\hline Totale exportwaarde (mld. euro) & 5,0 & $-4,8 \%$ \\
\hline Waarvan van Nederlandse makelij & $81 \%$ & \\
\hline Aandeel in de landbouwexport & $4,8 \%$ & \\
\hline Totale importwaarde (mld. euro) & 2,6 & $5,4 \%$ \\
\hline Aandeel in de landbouwimport & $3,6 \%$ & \\
\hline \multicolumn{3}{|c|}{ Belangrijkste exportbestemmingen ( $\mathrm{m} / \mathrm{n}$. euro) } \\
\hline China & 1.212 & -21 \\
\hline Duitsland & 761 & 19 \\
\hline België & 534 & 15 \\
\hline \multicolumn{3}{|c|}{ Belangrijkste herkomstlanden import (mln. euro) } \\
\hline Duitsland & 665 & 13 \\
\hline België & 620 & 7 \\
\hline Frankrijk & 195 & 16 \\
\hline
\end{tabular}

Bron: CBS tot en met oktober 2021, raming november - december 2021 door WUR en CBS.

\subsection{Bereidingen van aardappelen, groente en fruit: groei export}

Onder bereidingen van groenten en fruit wordt een diverse groep producten verstaan, zoals allerlei aardappelproducten, jam en andere bereidingen van fruit zoals mangochutney en fruitsappen.

In 2021 bedroeg de exportwaarde van bereidingen van groenten en fruit 5,3 miljard euro, een toename van 8,1\% ten opzichte van 2020 (tabel 4.11). Ten opzichte van 2019 is de exportgroei beperkter (1\%) en kan er gesproken worden van een herstel van de handel voor deze productgroep. De EU-27 is met $73 \%$ de belangrijkste afzetmarkt. Als het VK wordt meegerekend, dan stijgt dit percentage nog $10 \%$. De top drie is samen goed voor de helft van de exportwaarde.

De exportwaarde naar Duitsland bleef nagenoeg gelijk aan een jaar eerder met 1,3 miljard euro. Er was een toename van de export van bevroren aardappelproducten, een daling van fruitsappen bracht de exportwaarde 
nagenoeg in evenwicht met vorig jaar. De toename naar Frankrijk en België werd eveneens gedragen door een herstel van de export van bevroren aardappelproducten. Bij België speelde ook een toename van andere producten, zoals bereide groente, paddenstoelen en vruchtensap een rol in de exportgroei. Het herstel had te maken met de toegenomen mogelijkheden van de horeca en andere out-of-homekanalen om hun deuren te openen.

De importwaarde veranderde niet ten opzichte van 2020. De import uit de top drie landen laat een ander beeld zien. Brazilië, waar de importwaarde met $4 \%$ daalde, exporteerde vooral minder sinaasappelsap naar Nederland. Ook de handelsprijzen hadden niet het niveau van vorig jaar. Overigens kwam sinaasappelsap wel meer via België ons land binnen. Nederland importeerde uit België minder bevroren gekookte/gebakken aardappelen. De import uit Duitsland daalde ook door met name een lager importvolume van genoemd product.

Tabel 4.11 Nederlandse handel in bereidingen van groenten en fruit (GN-20)

\begin{tabular}{|c|c|c|}
\hline & 2021 (raming) & .2020 \\
\hline Totale exportwaarde (mld. euro) & 5,3 & $8,1 \%$ \\
\hline Waarvan van Nederlandse makelij & $73 \%$ & \\
\hline Aandeel in de landbouwexport & $5,0 \%$ & \\
\hline Totale importwaarde (mld. euro) & 2,7 & $0,0 \%$ \\
\hline Aandeel in de landbouwimport & $3,8 \%$ & \\
\hline \multicolumn{3}{|c|}{ Belangrijkste exportbestemmingen ( $\mathrm{m} / \mathrm{n}$. euro) } \\
\hline Duitsland & 1.314 & 1 \\
\hline Frankrijk & 693 & 10 \\
\hline België & 600 & 12 \\
\hline
\end{tabular}

\section{Belangrijkste herkomstlanden import (mIn. euro)}

\begin{tabular}{lll}
\hline België & 397 & -1 \\
\hline Brazilië & 378 & -4 \\
\hline Duitsland & 349 & -7 \\
\hline
\end{tabular}

Bron: CBS tot en met oktober 2021, raming november - december 2021 door WUR en CBS.

\subsection{Cacao: export en import nemen procentueel nagenoeg gelijk toe}

Nederland exporteerde in 2021 voor 4,8 miljard euro aan cacao en bereidingen van cacaoproducten. Dit is een krappe 10\% hoger dan in 2020 (tabel 4.12 ). Van de exportwaarde gaat $24 \%$ naar Duitsland en $13 \%$ naar België. Met Frankrijk en het VK (respectievelijk 11\% en 7\%) samen is dit afgerond $55 \%$ van de totale export. De exportwaarde naar de top drie landen steeg in lijn met de totale exportgroei van deze productgroep. Duitsland zat een procent hoger dan de gemiddelde groei. België zat daar net onder. Vooral naar Frankrijk steeg de exportwaarde procentueel sterk, door een stijging van het volume van cacaopasta. Dit speelde ook bij de export naar België. De groei naar Duitsland is te danken aan een toename van het volume cacaobonen.

Van de geëxporteerde cacao en bereidingen van cacaoproducten is $68 \%$ van Nederlandse makelij.

De importwaarde van cacao en cacaobereidingen was met 4,1 miljard euro in $20219,4 \%$ hoger dan in 2020. Het grootste deel van de import komt uit Ivoorkust (28\%). In de groep overige niet-EU-landen gaat het vooral om Ghana, Kameroen en Nigeria. Vooral uit Nigeria nam het importvolume van cacaobonen toe. Daarnaast komt de import via België (met een aandeel van $14 \%$ ) Nederland binnen. Amsterdam is een belangrijke cacaohaven. Zeeschepen worden hier overgeladen naar binnenvaartschepen om de cacaobonen naar de verwerkende industrie, onder andere in de Zaanstreek, te verschepen. De cacaobonen worden verwerkt tot allerlei (grondstoffen voor) eindproducten. 
Tabel 4.12 Nederlandse handel in cacao en -bereidingen (GN-18)

\begin{tabular}{lrr} 
& 2021 (raming) & mutatie t.o.v. 2020 \\
\hline Totale exportwaarde (mld. euro) & $\mathbf{4 , 8}$ & $\mathbf{9 , 7 \%}$ \\
\hline Waarvan van Nederlandse makelij & $68 \%$ & \\
\hline Aandeel in de landbouwexport & $4,6 \%$ & $\mathbf{4 , 1}$ \\
\hline Totale importwaarde (mld. euro) & $5,6 \%$ & $\mathbf{9 , 4 \%}$ \\
\hline Aandeel in de landbouwimport & 1.178 & 11 \\
\hline Belangrijkste exportbestemmingen (mln. euro) & 605 & 7 \\
\hline Duitsland & 526 & 31 \\
\hline België & & 29 \\
\hline Frankrijk & 1.289 & -4 \\
\hline Belangrijkste herkomstlanden import (mln. euro) & 1.125 & 15 \\
\hline Overig niet-EU & 553 & \\
\hline Ivoorkust & & \\
\hline België & & \\
\hline
\end{tabular}

Bron: CBS tot en met oktober 2021, raming november - december 2021 door WUR en CBS.

\subsection{Zaden en vruchten: import- en} exportwaarde nemen toe

Het gaat in handelshoofdstuk GN-12 vooral om producten als groentezaden, kool- en raapzaad en sojabonen. Ook zeewier, hop en stro vallen binnen deze groep. In 2021 nam de export met 6,5\% toe tot 4,0 miljard euro. De import van deze groep producten nam sterker toe, met $10,4 \%$ tot 4,9 miljard euro (tabel 4.13). Veruit de meeste export, 40\%, gaat naar Duitsland. Spanje en Frankrijk zijn met beide $6 \%$ een veel beperktere afzetmarkt.

De stijging van het exportaandeel van Duitsland was een gevolg van een stijgend volume én prijs van kool- en raapzaadexport. Ook de hogere prijs van sojabonen droeg bij aan de hogere exportwaarde. Naar Spanje steeg de exportwaarde door een sterke toename van de uitvoer van groentezaden. De prijzen hiervan namen sterk toe. Frankrijk kende een sterke plus in exportwaarde van grondnoten, dankzij hogere exportprijzen en volumegroei. Daarnaast was er een sterke toename van het exportvolume van kool- en raapzaad.
Van de totale waarde aan geëxporteerde zaden en vruchten was ongeveer $52 \%$ van Nederlandse makelij. Bij de exportwaarde naar Duitsland was dit aandeel $22 \%$. Van oudsher vindt er bij oliehoudende zaden en vruchten veel wederuitvoer plaats.

De importwaarde lag ruim 458 miljoen euro hoger dan een jaar eerder. De belangrijkste herkomstlanden zijn Brazilië en de VS. Hun importaandeel is respectievelijk $26 \%$ en $12 \%$. De stijging van de importwaarde uit Brazilië had vooral te maken met de toegenomen prijzen voor de inkoop van soja. Het volume kende weinig verandering. Uit de VS werden tegen een hogere prijs minder plantenzaden geïmporteerd, wat per saldo in een lagere importwaarde uitmondde. Ook was de importwaarde van grondnoten uit dat land lager dan in 2020. De import uit Oekraïne steeg verder, de importwaarde van kool- en raapzaad nam sterk toe door gestegen prijzen. Oekraïne leverde in 2021 wat meer sojabonen tegen hogere prijzen. Op de totaal geïmporteerde hoeveelheid sojabonen, is het aandeel van Oekraïne beperkt.

Tabel 4.13 Nederlandse handel in oliehoudende zaden en vruchten (GN-12)

\begin{tabular}{|c|c|c|}
\hline \multirow{2}{*}{ Totale exportwaarde (mld. euro) } & \multicolumn{2}{|c|}{2021 (raming) mutatie t.o.v. 2020} \\
\hline & 4,0 & $6,5 \%$ \\
\hline Waarvan van Nederlandse makelij & $52 \%$ & \\
\hline Aandeel in de landbouwexport & $3,9 \%$ & \\
\hline Totale importwaarde (mld. euro) & 4,9 & $10,4 \%$ \\
\hline Aandeel in de landbouwimport & $6,7 \%$ & \\
\hline \multicolumn{3}{|c|}{ Belangrijkste exportbestemmingen ( $\mathrm{mln}$. euro) } \\
\hline Duitsland & 1.599 & 15 \\
\hline Spanje & 250 & 20 \\
\hline Frankrijk & 238 & 42 \\
\hline \multicolumn{3}{|c|}{ Belangrijkste herkomstlanden import (mln. euro) } \\
\hline Brazilië & 1.270 & 61 \\
\hline VS & 606 & -9 \\
\hline Oekraïne & 387 & 37 \\
\hline
\end{tabular}

Bron: CBS tot en met oktober 2021, raming november - december 2021 door WUR en CBS. 


\subsection{Vis en zeevruchten: export en import stijgen}

De exportwaarde van vis en zeevruchten steeg met 11,5\% naar 3,3 miljard euro. Duitsland en België zijn de grootste exportbestemmingen, beide met een aandeel van $16 \%$. Italië, met een exportaandeel van $10 \%$, is weer terug op plek drie nadat het in het coronajaar 2020 minder vis en zeevruchten uit Nederland afnam (tabel 4.14). In 2021 was de exporttoename naar Italië met $24 \%$ het grootst. Een breed pakket vissoorten zorgde voor een hogere exportwaarde, maar schol en tong, waarvan de filets worden gemaakt die richting Italië gaan, hadden vooral baat bij de heropening van de horeca en daarmee oplevende vraag. Ook naar België (kreeft, zalm, garnalen en kabeljauw) en Duitsland (bevroren vis, zalm(filets) en garnalen) nam de export toe. Veelal ging het om volumestijgingen. Prijsstijgingen waren schaars.

De import van vis en zeevruchten bedroeg 2,3 miljard euro in 2021, wat ongeveer $10 \%$ hoger is dan in 2020. Naast de groep 'overige niet-EU-landen' waar zowel import uit IJsland als uit Venezuela onder vallen, is Duitsland het land waar Nederland de meeste vis uit importeert. De import uit Duitsland daalde met $5 \%$, mede onder invloed van een lagere import van bevroren makreel, en heeft nu een aandeel van $11 \%$, gevolgd door België (9\%). Denemarken en Noorwegen volgen met beide $8 \%$.

Tabel 4.14 Nederlandse handel in vis en zeevruchten (GN-03)

\begin{tabular}{|c|c|c|}
\hline & 2021 (raming) & v. 2020 \\
\hline Totale exportwaarde (mld. euro) & 3,3 & $11,5 \%$ \\
\hline Waarvan van Nederlandse makelij & $72 \%$ & \\
\hline Aandeel in de landbouwexport & $3,2 \%$ & \\
\hline Totale importwaarde (mld. euro) & 2,3 & $9,5 \%$ \\
\hline Aandeel in de landbouwimport & $3,2 \%$ & \\
\hline \multicolumn{3}{|c|}{ Belangrijkste exportbestemmingen (m/n. euro) } \\
\hline België & 539 & 15 \\
\hline Duitsland & 538 & 11 \\
\hline Italië & 334 & 24 \\
\hline \multicolumn{3}{|c|}{ Belangrijkste herkomstlanden import (mln. euro) } \\
\hline Overig niet-EU & 425 & 43 \\
\hline Duitsland & 244 & -5 \\
\hline België & 204 & 2 \\
\hline
\end{tabular}

Bron: CBS tot en met oktober 2021, raming november - december 2021 door WUR en CBS.

\subsection{Bereidingen van vlees en vis: export groeit naar 2 miljard euro}

De exportwaarde van bereidingsproducten van vlees en vis bedroeg 2 miljard euro in 2021, een toename van $9 \%$ ten opzichte van 2020 (tabel 4.15).

Duitsland en België waren ook in 2021 de belangrijkste exportbestemmingen, met een aandeel van respectievelijk $28 \%$ en $18 \%$. Frankrijk volgt op afstand met een aandeel van $10 \%$. De exportwaarde naar Duitsland groeide beperkt (2\%). Toegenomen exportwaarden van bereidingen van garnalen, visfilet en hammen stuwden de exportwaarde op. De groei werd geremd door een lagere exportwaarde van bereidingen en conserven van boniet, een vissoort, en kippenvlees. Naar België daalde de exportwaarde met 3\%. Vooral de toename aan exportwaarde naar Frankrijk valt op. Hoewel er een breed productenpakket aan de toename bijdroeg, was het vooral de productgroep bereidingen en conserven van hanen en kippenvlees en van geelvistonijn die voor deze toename zorgden. Van de totale waarde aan geëxporteerde bereidingen van vlees en vis was in 2020 circa $63 \%$ van Nederlandse makelij.

Nederland importeerde in 2020 voor 1,8 miljard euro aan bereidingsproducten van vlees en vis, 2,9\% meer dan in 2020. België, Duitsland en Thailand nemen het grootste deel (45\%) van de importwaarde voor hun rekening. De import uit Duitsland nam $10 \%$ toe. Een breed palet aan producten zorgde voor deze groei. Vooral bereidingen en conserven en slachtafval van kalkoenen, kippenvlees en garnalen werden meer geïmporteerd. Uit Thailand kwam vooral veel meer kippenvlees. 
Tabel 4.15 Nederlandse handel in bereidingen van vlees en vis (GN-16)

\begin{tabular}{|c|c|c|}
\hline & \multicolumn{2}{|c|}{2021 (raming) mutatie t.o.v. 2020} \\
\hline Totale exportwaarde (mld. euro) & 2,0 & $9,0 \%$ \\
\hline Waarvan van Nederlandse makelij & $63 \%$ & \\
\hline Aandeel in de landbouwexport & $1,9 \%$ & \\
\hline Totale importwaarde (mld. euro) & 1,8 & $2,9 \%$ \\
\hline Aandeel in de landbouwimport & $2,5 \%$ & \\
\hline \multicolumn{3}{|c|}{ Belangrijkste exportbestemmingen ( $\mathrm{m} / \mathrm{n}$. euro) } \\
\hline Duitsland & 560 & 2 \\
\hline België & 353 & -3 \\
\hline Frankrijk & 203 & 20 \\
\hline \multicolumn{3}{|c|}{ Belangrijkste herkomstlanden import (mln. euro) } \\
\hline België & 368 & -1 \\
\hline Duitsland & 282 & 10 \\
\hline Thailand & 158 & 26 \\
\hline
\end{tabular}

Bron: CBS tot en met oktober 2021, raming november - december 2021 door WUR en CBS.

\subsection{Levende dieren: export gedaald}

In 2021 bedroeg de export van levende dieren 1,7 miljard euro, een daling van 3,5\% vergeleken met 2020 (tabel 4.16). De belangrijkste exportproducten in deze handelsgroep zijn kippen, varkens, paarden en melkvee.

De exportwaarde wordt net als vorig jaar behoorlijk beïnvloed door de ontwikkelingen in de export van levende paarden naar de VS. Vanwege de coronacrisis was er in 2020 nauwelijks handel mogelijk met de VS. Dit jaar was er sprake van een meer genormaliseerde handel, wat zorgde voor een inhaalslag. De handel naar de VS steeg naar 232 miljoen euro. Dit is fors hoger dan in 2020, maar ook meer dan in 2019. Bij de export van levende dieren naar België en Duitsland spelen paarden een minder belangrijke rol. De export naar Duitsland van levende dieren stond vooral onder negatieve invloed van de coronaperikelen bij Duitse slachterijen. Door capaciteitsproblemen bleven meer varkens in Nederland om in eigen land te worden geslacht. Ook de prijzen waren lager. Verder worden er minder varkens gehouden in Nederland dan een jaar geleden. Naar België nam de export met $3 \%$ toe.
In 2021 bedroeg de importwaarde van levende dieren 1,2 miljard euro, ruim $3,4 \%$ hoger dan in 2020. De belangrijkste herkomstlanden van de import zijn Duitsland (46\%), België (28\%) en Denemarken (5\%). De minder frequente grensoverschrijdingen tussen Nederland en Duitsland komen ook bij de import terug. De import uit Duitsland daalde met 6\%, uit België met 2\%. De import uit Denemarken nam $20 \%$ af door lagere aantallen en waarden van varkens.

Tabel 4.16 Nederlandse handel in levende dieren (GN-01)

\begin{tabular}{lrr} 
& 2021 (raming) & mutatie t. O.v. 2020 \\
Totale exportwaarde (mld. euro) & $\mathbf{1 , 7}$ & $\mathbf{- 3 , 5 \%}$ \\
\hline Waarvan van Nederlandse makelij & $82 \%$ & \\
\hline Aandeel in de landbouwexport & $1,6 \%$ & $\mathbf{3 , 4 \%}$ \\
\hline Totale importwaarde (mld. euro) & $\mathbf{1 , 2}$ & \\
\hline Aandeel in de landbouwimport & $1,6 \%$ & -29 \\
\hline Belangrijkste exportbestemmingen (mIn. euro) & 525 & 3 \\
\hline Duitsland & 283 & 34 \\
\hline België & 232 & -6 \\
\hline VS & & -2 \\
\hline Belangrijkste herkomstlanden import (mln. euro) & 538 & -20 \\
\hline Duitsland & 326 & 61 \\
\hline België & & \\
\hline Denemarken & & \\
\hline
\end{tabular}

Bron: CBS tot en met oktober 2021, raming november - december 2021 door WUR en CBS.

\subsection{Suiker en suikerwerken: toename export en import}

Nederland exporteerde in 2021 voor 1,7 miljard euro aan suiker en suikerwerk, bijna $12 \%$ meer dan in 2020 (tabel 4.17). België (21\%) en Duitsland (19\%) zijn de belangrijkste exportbestemmingen, gevolgd door Frankrijk (7\%). Naar al deze landen steeg de exportwaarde, naar België zelfs zeer fors. Nagenoeg de gehele toename is terug te voeren op lactose (melksuiker), dankzij groei in volume en betere prijzen. Naar Duitsland nam de exportwaarde 3\% toe, naar Frankrijk 13\%. Naar Frankrijk nam vooral de export van witte suiker, gom- en geleiproducten, karamellen en toffees toe. 
De export van suiker en suikerwerk bestond in 2021 voor $79 \%$ uit goederen van Nederlandse makelij.

De import in 2021 bedroeg 0,9 miljard euro en was 5,5\% hoger dan in 2020 Van de import komt $28 \%$ uit Duitsland, $27 \%$ uit België en $8 \%$ uit Frankrijk. Hoewel de import vanuit Duitsland maar beperkt steeg, veranderde de samenstelling wel. Zo werd er veel meer lactose in vaste vorm geïmporteerd en veel minder gom en glucose. In de top drie importlanden valt de groei van de import uit België op. Vanuit België werden juist meer gom- en

geleiproducten ingevoerd. Ook nam de import van glucose in vaste vorm toe. De import uit Frankrijk liep met $12 \%$ terug. Minder maltodextrine, glucose in vaste vorm en witte suiker droegen daar aan bij.

Tabel 4.17 Nederlandse handel in suiker en suikerwerk (GN-17)

\begin{tabular}{|c|c|c|}
\hline & \multicolumn{2}{|c|}{2021 (raming) mutatie t.o.v. 2020} \\
\hline Totale exportwaarde (mld. euro) & 1,7 & $11,7 \%$ \\
\hline Waarvan van Nederlandse makelij & $79 \%$ & \\
\hline Aandeel in de landbouwexport & $1,6 \%$ & \\
\hline Totale importwaarde (mld. euro) & 0,9 & $5,5 \%$ \\
\hline Aandeel in de landbouwimport & $1,3 \%$ & \\
\hline \multicolumn{3}{|c|}{ Belangrijkste exportbestemmingen ( $\mathrm{m} / \mathrm{n}$. euro) } \\
\hline België & 346 & 76 \\
\hline Duitsland & 285 & 3 \\
\hline Frankrijk & 154 & 13 \\
\hline \multicolumn{3}{|c|}{ Belangrijkste herkomstlanden import (mIn. euro) } \\
\hline Duitsland & 263 & 2 \\
\hline België & 255 & 19 \\
\hline Frankrijk & 77 & -12 \\
\hline
\end{tabular}

Bron: CBS tot en met oktober 2021, raming november - december 2021 door WUR en CBS.

\subsection{Koffie, thee en specerijen: groei export- en importwaarde}

De exportwaarde van koffie, thee en specerijen bedroeg 1,3 miljard euro in 2021 , een toename van $6,6 \%$ in vergelijking met 2020 . Dit is net iets meer dan de procentuele groei van de import (tabel 4.18). Frankrijk (22\%), Duitsland (16\%) en België (13\%) zijn de belangrijkste exportbestemmingen.

De export naar Frankrijk steeg met $11 \%$, naar Duitsland met $12 \%$ en naar België met $8 \%$. Zowel naar Frankrijk als Duitsland steeg de exportwaarde van gebrande koffie, vooral het volume groeide. De exportgroei naar België komt vooral door een toename (in prijs en volume) van ongebrande koffie. De exportwaarde van koffie, thee en specerijen bestond in 2021 voor 55\% uit goederen van Nederlandse makelij. Een groot deel van de export betreft dus wederuitvoer.

De top drie exportlanden zijn ook de belangrijkste landen van herkomst, hoewel de volgorde iets anders is. België en Duitsland (beide 18\%) en Frankrijk (14\%) hadden het grootste aandeel in de import. Terwijl de import uit België een beperkte waardeverandering onderging, lagen de importwaarden uit Duitsland en Frankrijk een stuk hoger dan een jaar eerder. De import uit Duitsland steeg door een toename van on- en gebrande koffie met cafeïne. Uit Frankrijk kwam vooral meer gebrande koffie.

Tabel 4.18 Nederlandse handel in koffie, thee en specerijen (GN-09)

\begin{tabular}{|c|c|c|}
\hline & 2021 (raming) & .2020 \\
\hline Totale exportwaarde (mld. euro) & 1,3 & $6,6 \%$ \\
\hline Waarvan van Nederlandse makelij & $55 \%$ & \\
\hline Aandeel in de landbouwexport & $1,2 \%$ & \\
\hline Totale importwaarde (mld. euro) & 1,6 & $5,4 \%$ \\
\hline Aandeel in de landbouwimport & $2,2 \%$ & \\
\hline \multicolumn{3}{|c|}{ Belangrijkste exportbestemmingen (m/n. euro) } \\
\hline Frankrijk & 279 & 11 \\
\hline Duitsland & 196 & 12 \\
\hline België & 161 & 8 \\
\hline \multicolumn{3}{|c|}{ Belangrijkste herkomstlanden import (mIn. euro) } \\
\hline België & 296 & -2 \\
\hline Duitsland & 295 & 14 \\
\hline Frankrijk & 233 & 11 \\
\hline
\end{tabular}

Bron: CBS tot en met oktober 2021, raming november - december 2021 door WUR en CBS. 


\subsection{Tabak en tabaksproducten: sterke procentuele exportdaling}

In 2021 nam evenals voorgaande jaren de exportwaarde van tabak en tabaksproducten af. De exportwaarde kwam op 0,9 miljard euro uit, een daling van $10 \%$ (tabel 4.19 ). Van al deze producten ging $28 \%$ naar Duitsland en $14 \%$ naar België. Door een sterke toename (287\%) van de exportwaarde naar Taiwan steeg het aandeel van dat land naar $7 \%$. Naar Duitsland werd vooral minder rooktabak of surrogaten daarvan en sigaretten geëxporteerd. De rooktabak is de reden voor de waardestijging van de export naar Taiwan.

Het aandeel van tabak en tabaksproducten in de totale landbouwexport is in 2021 net geen $1 \%$. Van de geëxporteerde waarde aan tabak en tabaksproducten is $67 \%$ van Nederlandse makelij.

Tabel 4.19 Nederlandse handel in tabak en tabaksproducten (GN-24)

\begin{tabular}{lrr} 
& 2021 (raming) & mutatie t.o.v. 2020 \\
Totale exportwaarde (mld. euro) & $\mathbf{0 , 9}$ & $\mathbf{- 1 0 , 0 \%}$ \\
\hline Waarvan van Nederlandse makelij & $67 \%$ & \\
\hline Aandeel in de landbouwexport & $0,8 \%$ & \\
\hline Totale importwaarde (mld. euro) & $\mathbf{0 , 7}$ & $\mathbf{- 1 4 , 5 \%}$ \\
\hline Aandeel in de landbouwimport & $0,9 \%$ & \\
\hline Belangrijkste exportbestemmingen (mln. euro) & 244 & -11 \\
\hline Duitsland & 127 & 3 \\
\hline België & 64 & 287 \\
\hline Taiwan & & 73 \\
\hline Belangrijkste herkomstlanden import (mln. euro) & 136 & -35 \\
\hline Overig EU & 127 & -19 \\
\hline Polen & 117 &
\end{tabular}

Bron: CBS tot en met oktober 2021, raming november - december 2021 door WUR en CBS.

In 2021 bedroeg de import van tabak en tabaksproducten 0,7 miljard euro, een daling van bijna $15 \%$ ten opzichte van 2020 . Het belangrijkste herkomstland is Litouwen, dat onder de groep overige EU-landen valt. Deze gezamenlijke groep landen heeft een aandeel van 20\%: dat is net iets meer dan het aandeel dat uit Polen wordt geïmporteerd (19\%). De import uit België heeft een aandeel van $17 \%$. De import uit Litouwen nam toe door een toename van de import van sigaretten, ten nadele van Polen. De lagere importwaarde uit België is toe te schrijven aan een lager volume van sigaren en tabak.

\subsection{Meel, mout en zetmeel: export toegenomen}

In 2021 bedroeg de exportwaarde van meel, mout en zetmeelproducten 904 miljoen euro; dat is een toename van bijna $15 \%$ ten opzichte van 2020 (tabel 4.20). Van alle geëxporteerde goederen ging in 2021 14\% zowel naar Duitsland als naar België. Andere niet EU-landen complementeren de top drie. Naar zowel België als Duitsland nam de export toe tot 127 miljoen euro. Naar België steeg de exportwaarde van ongebrande mout door vooral een hoger volume bij toegenomen prijzen. Naar Duitsland nam de export toe door een toename van moutexport, maar ook door een hogere exportwaarde van granen van mais- en tarwezetmeel. Mout is een belangrijke grondstof voor het maken van bier. De bierproductie en -consumptie stond vorig jaar onder druk door de opgelegde coronamaatregelen. Dit jaar was meer mogelijk, waardoor de vraag toenam. De exportwaarde van meelindustrieproducten is voor circa $86 \%$ van Nederlandse makelij.

Tabel 4.20 Nederlandse handel in meel, mout en zetmeel (GN-11)

\begin{tabular}{|c|c|c|}
\hline \multirow{2}{*}{ Totale exportwaarde (mld. euro) } & \multicolumn{2}{|c|}{2021 (raming) mutatie t.o.v. 2020} \\
\hline & 0,9 & $14,5 \%$ \\
\hline Waarvan van Nederlandse makelij & $86 \%$ & \\
\hline Aandeel in de landbouwexport & $0,9 \%$ & \\
\hline Totale importwaarde (mld. euro) & 0,8 & $6,5 \%$ \\
\hline Aandeel in de landbouwimport & $1,1 \%$ & \\
\hline \multicolumn{3}{|c|}{ Belangrijkste exportbestemmingen ( $\mathrm{m} / \mathrm{n}$. euro) } \\
\hline België & 127 & 32 \\
\hline Duitsland & 127 & 18 \\
\hline Overig niet-EU & 109 & 4 \\
\hline \multicolumn{3}{|c|}{ Belangrijkste herkomstlanden import (mln. euro) } \\
\hline België & 307 & 29 \\
\hline Duitsland & 281 & -5 \\
\hline Frankrijk & 77 & -23 \\
\hline
\end{tabular}

Bron: CBS tot en met oktober 2021, raming november - december 2021 door WUR en CBS. 
In 2021 bedroeg de import van meel, mout en zetmeel 822 miljoen euro, dat is meer dan in $2020(6,5 \%)$. Het grootste deel van de import komt uit België (37\%), Duitsland (34\%), en Frankrijk (9\%). De toename van de import uit België kwam vooral door de toename van import van al dan niet gedroogde tarwegluten. De hogere importwaarde kwam tot stand door zowel een hoger volume als een hogere prijs. De daling uit Frankrijk heeft te maken met een lagere invoer van tarwegluten. Vanuit Duitsland werd minder

aardappelzetmeel geïmporteerd. Een hogere prijs compenseerde de daling in waarde enigszins.

\subsection{Overige producten van dierlijke oorsprong: daling import en onveranderde export}

Nederland exporteerde in 2021 voor 613 miljoen euro aan overige producten van dierlijke oorsprong. Dit is bijna $5 \%$ meer dan een jaar eerder (tabel 4.21). Het gaat hier om een diverse groep producten, zoals rundersperma, darmen, blazen, magen, veren, haren en visafval. Van deze producten ging $23 \%$ naar Duitsland en $11 \%$ naar zowel Frankrijk als China. Van de waarde aan geëxporteerde goederen is $38 \%$ van Nederlandse makelij. Een kleine twee derde deel van de export bestaat uit wederuitvoer.

De exporttoename naar Duitsland en Frankrijk betrof vooral een stijging van de exportwaarde van niet nader gespecificeerde dode dieren of onderdelen daarvan die niet geschikt zijn voor menselijke consumptie, van vogelhuiden en vogelveren en van visafvallen. Naar China nam de export toe door een toename van de exportwaarde aan darmen, blazen en beenderen van dieren.

In 2021 bedroeg de import van andere producten van dierlijke oorsprong 408 miljoen euro, een afname van 7,4\% ten opzichte van 2020. De daling is vooral een gevolg van de afname van de handel met China (-27\%). Onder andere de vervoersproblematiek speelt hierin een rol. China is nu met een importaandeel van $27 \%$ niet langer het belangrijkste herkomstland. Door een toename van de import uit Duitsland $(+2 \%)$ steeg het Duitse importaandeel naar (29\%). Vanuit China veranderde de importwaarde door een sterke volumedaling van 'darmen, blazen en magen'. Deze daling van de import werd ten dele opgevangen door een groei vanuit diverse Europese landen. De toename van de import uit België kwam door gestegen prijzen bij een lager volume.

Tabel 4.21 Nederlandse handel in overige producten van dierlijke oorsprong (GN-05)

\begin{tabular}{|c|c|c|}
\hline & 2021 (raming) & v. 2020 \\
\hline Totale exportwaarde (mld. euro) & 0,6 & $4,7 \%$ \\
\hline Waarvan van Nederlandse makelij & $38 \%$ & \\
\hline Aandeel in de landbouwexport & $0,6 \%$ & \\
\hline Totale importwaarde (mld. euro) & 0,4 & $-7,4 \%$ \\
\hline Aandeel in de landbouwimport & $0,6 \%$ & \\
\hline \multicolumn{3}{|c|}{ Belangrijkste exportbestemmingen (m/n. euro) } \\
\hline Duitsland & 138 & 15 \\
\hline Frankrijk & 65 & 12 \\
\hline China & 65 & 9 \\
\hline \multicolumn{3}{|c|}{ Belangrijkste herkomstlanden import (mIn. euro) } \\
\hline Duitsland & 119 & 2 \\
\hline China & 108 & -27 \\
\hline België & 46 & 34 \\
\hline
\end{tabular}

Bron: CBS tot en met oktober 2021, raming november - december 2021 door WUR en CBS.

\subsection{Granen: exportwaarde daalt, importwaarde stijgt}

De exportwaarde van granen bedroeg in 2021498 miljoen euro, een daling van bijna $13 \%$ ten opzichte van 2020 (tabel 4.22). Vooral de export naar Duitsland en Frankrijk nam sterk af. De daling naar België bleef met $2 \%$ beperkt. Samen zijn deze drie landen goed voor driekwart van de exportwaarde. Overigens is Nederland een netto-importeur voor deze goederengroep. De daling van de export naar Duitsland kwam door een afname van de volumes van mais. Ook naar België daalde het exportvolume van mais. In 2021 was de export van granen voor $41 \%$ van Nederlandse makelij.

De importwaarde steeg met ruim $16 \%$, een stijging die absoluut gezien veel sterker is dan de exportafname. Dit jaar is Duitsland met een aandeel van 
$26 \%$ het belangrijkste importland, Frankrijk is met een aandeel van $23 \%$ het tweede herkomstland. Het aandeel van Oekraïne is $16 \%$. Uit Frankrijk werd minder tarwe tegen een hogere prijs ingevoerd. Daar stond een grotere hoeveelheid tarwe uit Duitsland tegenover, tegen hogere marktprijzen. Uit het verder weg gelegen Oekraïne werd in 2021 een veel lager volume mais geïmporteerd tegen hogere prijzen. Wel kwam er meer tarwe uit Oekraïne tegen een lagere prijs. Per saldo is er in 2021 voor de import van granen uit Oekraïne een kleine waardedaling ten opzichte van 2020

Tabel 4.22 Nederlandse handel in granen (GN-10)

\begin{tabular}{lrr} 
& 2021 (raming) & mutatie t.o.v. 2020 \\
\hline Totale exportwaarde (mld. euro) & $\mathbf{0 , 5}$ & $\mathbf{- 1 2 , 6 \%}$ \\
\hline Waarvan van Nederlandse makelij & $41 \%$ & \\
\hline Aandeel in de landbouwexport & $0,5 \%$ & $\mathbf{1 6 , 3 \%}$ \\
\hline Totale importwaarde (mld. euro) & $\mathbf{3 , 3}$ & \\
\hline Aandeel in de landbouwimport & $4,5 \%$ & -20 \\
\hline Belangrijkste exportbestemmingen (mIn. euro) & & -2 \\
\hline Duitsland & 182 & -27 \\
\hline België & 153 & \\
\hline Frankrijk & 38 & 51 \\
\hline Belangrijkste herkomstlanden import (mln. euro) & & 12 \\
\hline Duitsland & 851 & -3 \\
\hline Frankrijk & 768 & 534 \\
\hline Oekraïne & &
\end{tabular}

Bron: CBS tot en met oktober 2021, raming november - december 2021 door WUR en CBS.

\subsection{Plantensappen: meer export en import}

In 2021 steeg de export van plantensappen met ruim 14\%. De exportwaarde van plantensappen is gering met 105 miljoen euro (tabel 4.23). Onder deze productgroep vallen onder andere zoethout(drop), hopextracten en pectine.

Door de lage absolute waarde zijn de procentuele verschillen groot. De procentuele toename van de export naar België valt hierdoor op, deze is sterk beïnvloed door een hoger volume van plantensappen die tegen hogere exportprijzen werden verhandeld. Naar Duitsland ging het om een volumestijging, de prijzen stonden onder druk. De exportwaarde naar het VK nam af. Bij een sterk toegenomen prijs was het volume substantieel lager dan een jaar eerder. Van de totale waarde aan geëxporteerde plantensappen is $59 \%$ van Nederlandse makelij.

De importwaarde van plantensappen bedroeg in 2021 bijna 184 miljoen euro en nam met ruim $13 \%$ toe ten opzichte van 2020 . De belangrijkste herkomstlanden zijn Duitsland (20\%) en Frankrijk (13\%), een deel komt uit overige niet-EU-landen zoals de Dominicaanse Republiek. De import steeg het sterkste uit Duitsland door groei van de import van plantensappen, extract van zoethout en pectine. Uit Frankrijk werden voor een hogere waarde plantensappen, pectine en plantenslijmen en bindmiddelen uit de guarzaden geïmporteerd.

Tabel 4.23 Nederlandse handel in plantensappen (GN-13)

\begin{tabular}{|c|c|c|}
\hline & 2021 (raming) & v. 2020 \\
\hline Totale exportwaarde (mln. euro) & 105,3 & $14,1 \%$ \\
\hline Waarvan van Nederlandse makelij & $59 \%$ & \\
\hline Aandeel in de landbouwexport & $0,1 \%$ & \\
\hline Totale importwaarde (m/n. euro) & 183,7 & $13,5 \%$ \\
\hline Aandeel in de landbouwimport & $0,3 \%$ & \\
\hline \multicolumn{3}{|c|}{ Belangrijkste exportbestemmingen ( $\mathrm{m} / \mathrm{n}$. euro) } \\
\hline Duitsland & 22 & 20 \\
\hline België & 13 & 55 \\
\hline Verenigd Koninkrijk & 11 & -6 \\
\hline \multicolumn{3}{|c|}{ Belangrijkste herkomstlanden import (mln. euro) } \\
\hline Duitsland & 37 & 35 \\
\hline Overig niet-EU & 30 & 79 \\
\hline Frankrijk & 24 & 14 \\
\hline
\end{tabular}

Bron: CBS tot en met oktober 2021, raming november - december 2021 door WUR en CBS.

\subsection{Vlechtstoffen: hogere importwaarde}

De exportwaarde van vlechtstoffen (zoals bamboe en riet) bedroeg in 2021 bijna 42 miljoen euro, een afname van $5 \%$ ten opzichte van 2020 . Het aandeel in de totale landbouwexport is zeer beperkt (tabel 4.24). De belangrijkste exportbestemmingen zijn de VS (24\%), het VK (21\%) en 
Duitsland (18\%). De export naar de VS liep terug door hogere vervoerskosten. De export naar andere landen in de top drie kende een beperkte toename. In 2021 bestond de exportwaarde van vlechtstoffen voor $42 \%$ uit producten van Nederlandse makelij.

Nederland importeerde voor 107 miljoen euro aan vlechtstoffen. De twee belangrijkste herkomstlanden zijn India (39\%) en China (29\%). Uit India kwamen overige plantaardige producten in grotere hoeveelheden en tegen een hogere prijs naar ons land. Uit China komt vooral bamboe, in 2021 was er sprake van prijs- en volumegroei. De procentuele mutaties zijn groot.

Tabel 4.24 Nederlandse handel in vlechtstoffen (GN-14)

\begin{tabular}{|c|c|c|}
\hline & \multicolumn{2}{|c|}{2021 (raming) mutatie t.o.v. 2020} \\
\hline Totale exportwaarde (mln. euro) & 41,7 & $-5,0 \%$ \\
\hline Waarvan van Nederlandse makelij & $42 \%$ & \\
\hline Aandeel in de landbouwexport & $0,0 \%$ & \\
\hline Totale importwaarde (mln. euro) & 107,0 & $31,0 \%$ \\
\hline Aandeel in de landbouwimport & $0,1 \%$ & \\
\hline \multicolumn{3}{|c|}{ Belangrijkste exportbestemmingen ( $\mathrm{m} / \mathrm{n}$. euro) } \\
\hline VS & 10 & -19 \\
\hline Verenigd Koninkrijk & 9 & 1 \\
\hline Duitsland & 8 & 4 \\
\hline \multicolumn{3}{|c|}{ Belangrijkste herkomstlanden import (mIn. euro) } \\
\hline India & 42 & 53 \\
\hline China & 31 & 25 \\
\hline Duitsland & 6 & 24 \\
\hline
\end{tabular}

Bron: CBS tot en met oktober 2021, raming november - december 2021 door WUR en CBS.

\subsection{Overige primaire en secundaire landbouwgoederen: sterke toename handel}

De exportwaarde van overige primaire en secundaire landbouwproducten bedroeg 5,5 miljard euro in 2021 (tabel 4.25). Dit is een stijging van ruim $34 \%$ ten opzichte van 2020. In deze productgroep zitten onder andere glycerol, rubber, katoen en diverse oliën, hout en vetzuren.
Duitsland is de belangrijkste exportbestemming (19\%), gevolgd door China (11\%) en België (10\%). De export werd gestimuleerd door de toename van de verkoopwaarde en hoeveelheid van vetzuren en lactoalbumine naar Duitsland, hout met bestemming China, en industriële vetalcoholen naar België. De exportwaarde van deze overige primaire en secundaire

landbouwgoederen bestaat voor drie kwart uit goederen van Nederlandse makelij. Deze diverse groep heeft een aandeel van ruim $5,2 \%$ in de totale land- en tuinbouwexport. Bij de import gaat het om ruim $7,8 \%$.

De import van deze groep landbouwproducten bedroeg 5,6 miljard euro in 2021 , een toename met ruim $32 \%$ ten opzichte van 2020 . De import kwam in 2021 met name uit Duitsland (16\%), Indonesië (12\%) en België (9\%). De import uit Duitsland was onder andere hoger door volumegroei en gestegen houtprijzen. Import uit Indonesië steeg onder andere door de toename van vetzuurdistillaat. Dit kan gebruikt worden in bijvoorbeeld coatings, lijmen en kunststoffen (MVO, 2021)

Tabel 4.25 Nederlandse handel in overige primaire en secundaire landbouwgoederen

\begin{tabular}{lrr} 
& 2021 (raming) & mutatie t.o.v. 2020 \\
Totale exportwaarde (mld. euro) & $\mathbf{5 , 5}$ & $\mathbf{3 4 , 2 \%}$ \\
\hline Waarvan van Nederlandse makelij & $75 \%$ & \\
\hline Aandeel in de landbouwexport & $5,2 \%$ & \\
\hline Totale importwaarde (mld. euro) & $\mathbf{5 , 6}$ & $\mathbf{3 2 , 2 \%}$ \\
\hline Aandeel in de landbouwimport & $7,8 \%$ & \\
\hline Belangrijkste exportbestemmingen (mln. euro) & & 25 \\
\hline Duitsland & 1.017 & 114 \\
\hline China & 592 & 32 \\
\hline België & 527 & 28 \\
\hline Belangrijkste herkomstlanden import (mln. euro) & & 55 \\
\hline Duitsland & 926 & 19 \\
\hline Indonesië & 656 & \\
\hline België & 530 & \\
\hline
\end{tabular}

Bron: CBS tot en met oktober 2021, raming november - december 2021 door WUR en CBS 


\subsection{Exportverdiensten: grootste groei bij vleesexport}

In hoofdstuk 3 zijn de landbouwexportverdiensten van hoofdstuk 2 uitgesplitst naar landen van bestemming, in deze paragraaf worden de verdiensten uitgesplitst naar soorten landbouwgoederen. Ook voor deze uitsplitsing geldt dat de informatie enkel nog beschikbaar is tot en met verslagjaar 2020. Op productniveau is te zien dat Nederland het meest verdient aan de export van sierteelt (6,0 miljard euro in 2020), waarvan 5,7 miljard door de export van Nederlandse makelij en 0,3 miljard dankzij wederuitvoer (zie figuur 4.1). $\mathrm{Na}$ sierteelt volgt de export van vlees (4,6 miljard euro), zuivel en eieren

(4,3 miljard euro) en groenten (3,9 miljard euro). Bereidingen van graan, meel en melk, zoals babymelkpoeder, staan op plek 5 ( 2,7 miljard euro),

daarna volgen bereidingen van groente en fruit, dranken, cacaobereidingen, resten voedselindustrie/veevoer en de export van natuurlijke vetten en oliën.

Net buiten de top tien, maar in bedrag vrijwel gelijk aan de nummer tien, staat de fruitexport (1,2 miljard euro). De fruitexport staat een stuk lager dan bij de exportwaarde (eerste deel van dit hoofdstuk) omdat het grootste deel wederuitvoer van buitenlands fruit betreft, fruit waaraan Nederland relatief weinig verdient.

Een vergelijking met de rangschikking voor het jaar 2019 leert dat er vrijwel niets is veranderd in de volgorde van goederen. Enkel de natuurlijke vetten en oliën zijn fruit gepasseerd (van 11 naar 10).

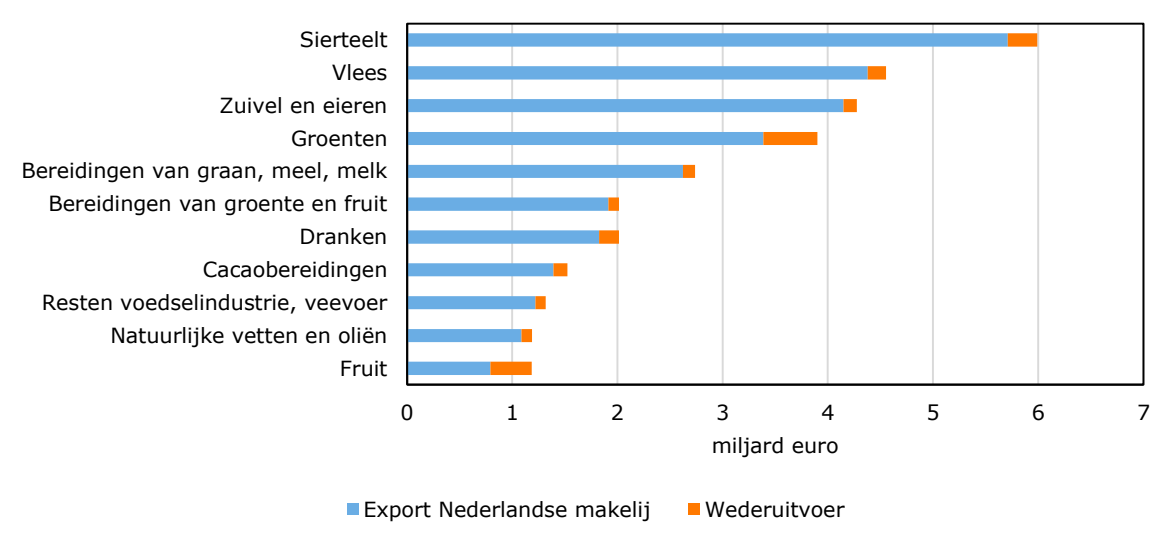

Figuur 4.1 Landbouwgoederen met grootste exportverdiensten, 2020 Bron: CBS (waardeketenonderzoek).

Sierteelt is ook het meest lucratieve agrarische exportproduct indien wordt gerekend naar de verdiensten per euro exportwaarde (zie figuur 4.2). Aan een euro sierteeltexport verdiende Nederland 68 eurocent in 2020. Voor enkel Nederlandse sierteelt is dat zelfs 83 eurocent per euro exportwaarde. Ook Nederlandse groenten en fruit zijn met 79 eurocent exportverdiensten per euro export bovengemiddeld lucratief. De totale fruitexport is veel minder lucratief door de grote invloed van wederuitvoer.

De gemiddelde landbouwexport levert 43 eurocent per euro exportwaarde op en dat is 60 eurocent indien wordt gezuiverd voor wederuitvoer. Dat zijn dezelfde cijfers als een jaar eerder. 


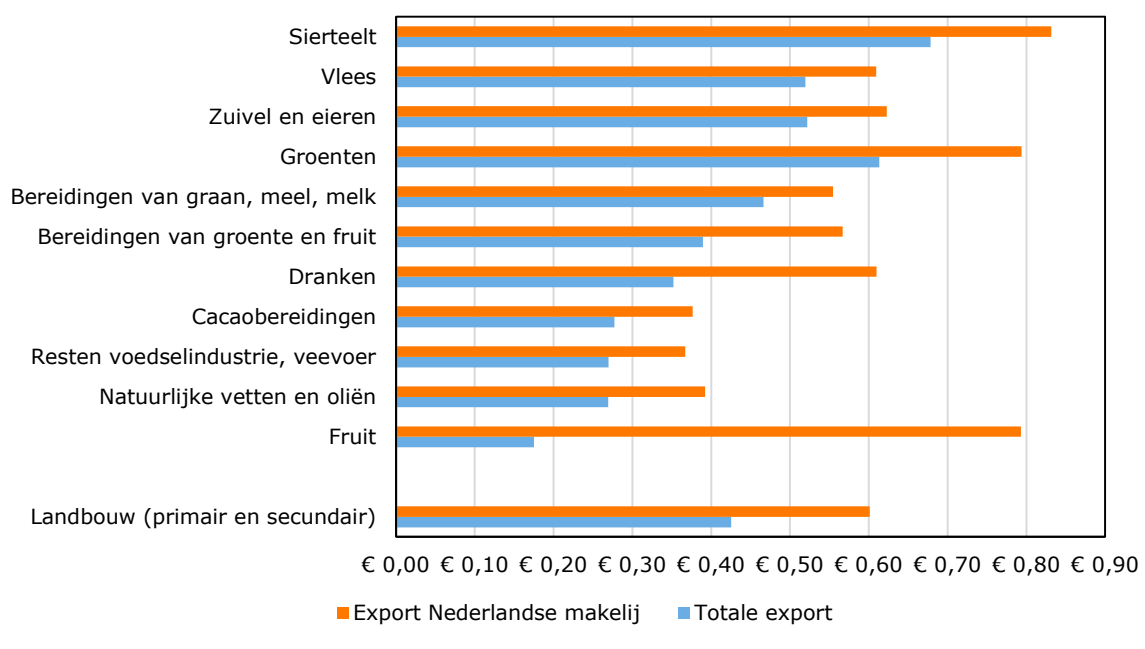

Figuur 4.2 Exportverdiensten per euro exportwaarde, 2020 Bron: CBS (waardeketenonderzoek).

Door een vergelijking te maken met 2015 wordt duidelijk waar de grootste groei zit als het gaat om de verdiensten aan de landbouwexport (zie figuur 4.3). De grootste groei betreft de vleesexport met 1,1 miljard euro meer exportverdiensten in 2020 dan in 2015. Dat is onder meer door een sterke stijging van de export van varkensvlees naar China in de afgelopen jaren. Daarna volgen de bereidingen van graan, meel en melk ( $+0,9$ miljard euro), dan gaat het met name om een groeiend belang van de export van babymelkpoeder naar China. Ook de export van zuivel en eieren alsmede de export van bereidingen van groenten en fruit is in toenemende mate lucratief. Op een vijfde plek staat de fruitexport met een toename van 0,4 miljard euro. Daarbij gaat het onder meer om de toegenomen verdiensten aan de wederuitvoer van buitenlandse fruit zoals avocado's. De export van het belangrijkste exportproduct sierteelt staat niet meer in deze top vijf na een tegenvallend coronajaar 2020. De exportverdiensten van sierteeltproducten zijn in de gehele periode wel toegenomen, met circa 0,25 miljard euro.

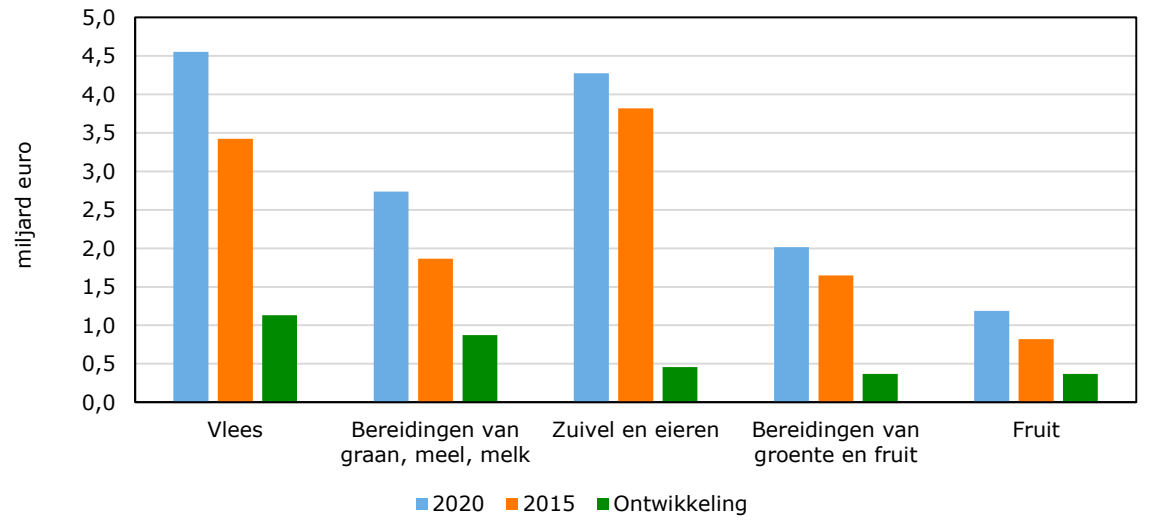

Figuur 4.3 Grootste toenames in exportverdiensten, 2015-2020 Bron: CBS (waardeketenonderzoek). 


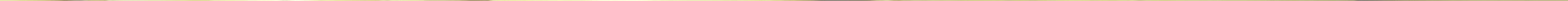




\section{De handel in landbouwgerelateerde goederen}

\section{$5.1 \quad$ Inleiding}

In dit hoofdstuk ligt de focus op landbouwgerelateerde goederen: dit zijn goederen die internationaal worden verhandeld ten behoeve van landbouw- of voedingssectoren. Bekende voorbeelden zijn landbouwmachines en machines voor de voedingsmiddelenindustrie, maar ook bijvoorbeeld meststoffen en gewasbeschermingsmiddelen behoren tot de landbouwgerelateerde goederen.

De landbouwgerelateerde goederen (of tertiaire landbouwgoederen) vormen samen met de (primaire en secundaire) landbouwgoederen, een bredere definitie van de Nederlandse handel in landbouwgoederen. In paragraaf 5.1 komen de macro-ontwikkelingen aan bod, paragraaf 5.2 voegt een landendimensie toe, paragraaf 5.3 een goederendimensie en paragraaf 5.4 bespreekt de Nederlandse verdiensten aan de export van landbouwgerelateerde goederen.

\subsection{Voor het eerst meer dan 10 miljard euro tertiaire export}

Voor 2021 wordt de export van landbouwgerelateerde goederen geraamd op 10,6 miljard euro (figuur 5.1). Dat is 10\% meer dan in 2020 ( 9,6 miljard), een vergelijkbaar percentage als bij de landbouw (volgens de basisdefinitie, zie hoofdstuk 2). Een andere overeenkomst is dat beide een mijlpaal hebben bereikt: de landbouw komt voor het eerst boven de 100 miljard euro export uit en de landbouwgerelateerde export heeft nu de mijlpaal van 10 miljard euro geslecht.

De import van landbouwgerelateerde goederen wordt ook geraamd op een nieuw record (5,3 miljard), 14\% meer dan in 2020 en voor het eerst meer dan 5 miljard euro. Door deze ontwikkelingen is het handelsoverschot in landbouwgerelateerde goederen nu vrijwel precies even groot als de import (dus twee keer zoveel export- als importwaarde). Alleen in 2019 was het handelsoverschot iets groter. Over de gehele periode 2010-2020 is het handelsoverschot met $79 \%$ toegenomen, dat is iets meer dan de exportgroe $(76 \%)$ en de importgroei $(73 \%)$ in deze periode.

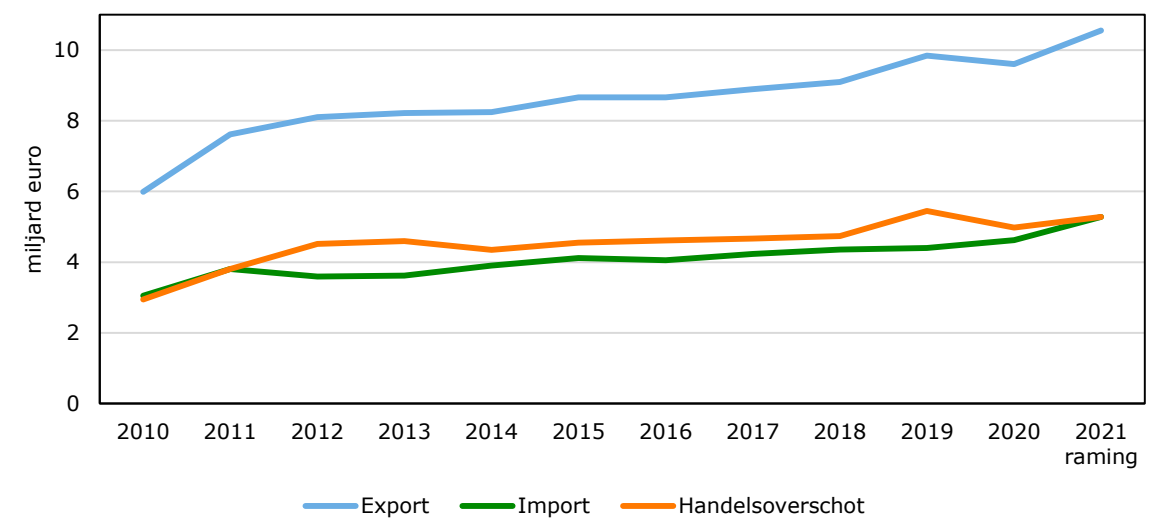

Figuur 5.1 Import, export en handelsoverschot bij landbouwgerelateerde goederen

Bron: CBS tot en met oktober 2021, raming november-december 2021 door CBS en Wageningen Economic Research.

Nu de cijfers over de handel in landbouwgerelateerde goederen bekend zijn, is het ook mogelijk om iets te zeggen over het 'brede' landbouwexportcijfer met de primaire, secundaire en tertiaire landbouwgoederen samengeteld

(figuur 5.2). De export van de landbouw- en landbouwgerelateerde export wordt voor 2021 geraamd op 115,3 miljard euro voor 2021, 9,4\% hoger dan het oude record van 105,3 miljard euro in 2020 . Ook de brede landbouwimport 
komt uit op een nieuw record met een bedrag van 77,8 miljard euro in 2021 ( $+10,2 \%$ in 2021). Ook het totale handelsoverschot komt uit op het hoogste bedrag ooit met 37,5 miljard euro (7,8\% groei in 2021$)$.

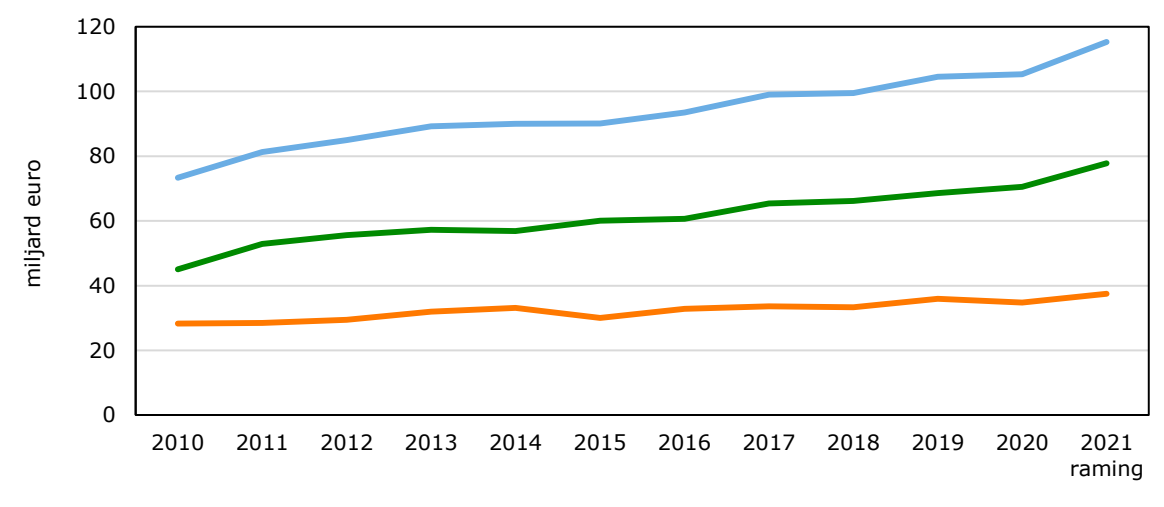

Figuur 5.2 Import, export en handelsoverschot bij landbouw- en landbouwgerelateerde goederen

Bron: CBS tot en met oktober 2021, raming november-december 2021 door CBS en Wageningen Economic Research.

\subsection{Tertiaire export naar het VK daalt met $21 \%$}

De export van landbouwgerelateerde goederen (figuur 5.3) leunt op veel vertrouwde bestemmingen. De top vijf wordt vertegenwoordigd door Duitsland ( $15 \%$ van het totaal), België en Frankrijk (elk 11\%), VS en het VK (elk 6\%). Landbouwmachines domineren de export naar Duitsland en het VK. Bij de export naar België en Frankrijk staan meststoffen bovenaan en bij de export naar de VS machines voor de voedingsmiddelenindustrie.

Er staan echter ook enkele bestemmingen bij die niet in de top tien van landbouwgoederen (figuur 3.2) staan. Zo staat Brazilië (in de eerste plaats meststoffen) op plaats acht als bestemming van tertiaire landbouwexport en komt Canada, met bovenaan landbouwmachines, naar voren op plek tien.
In vergelijking met 2020 zijn de exportontwikkelingen heel wisselend. De opvallendste ontwikkeling betreft wel de afname van de export naar het VK $(-21 \%)$. Het gaat hier met name om een sterke afname van de export van kasmaterialen nadat de export hiervan vorig jaar nog sterk toenam. Het betreft de enige significante afname in de lijst van belangrijkste bestemmingen (de export naar Canada en China is licht afgenomen, met respectievelijk $4 \%$ en $3 \%)$.

Bij de bestemmingen met exportgroei zijn er ook onderlinge verschillen. Zo nam de export naar Duitsland $(+7 \%)$ ondergemiddeld toe, terwijl de export naar Brazilië $(+44 \%)$ en Frankrijk (+34\%) juist spectaculair groeide. Bij beide landen gaat het met name om een groei van de export van meststoffen (zowel prijsstijging als volumegroei), in het geval van Frankrijk ook om fors meer kasmaterialenexport. Brazilië is een nieuwkomer in de top tien, terwijl Rusland niet meer in de top tien te vinden is.

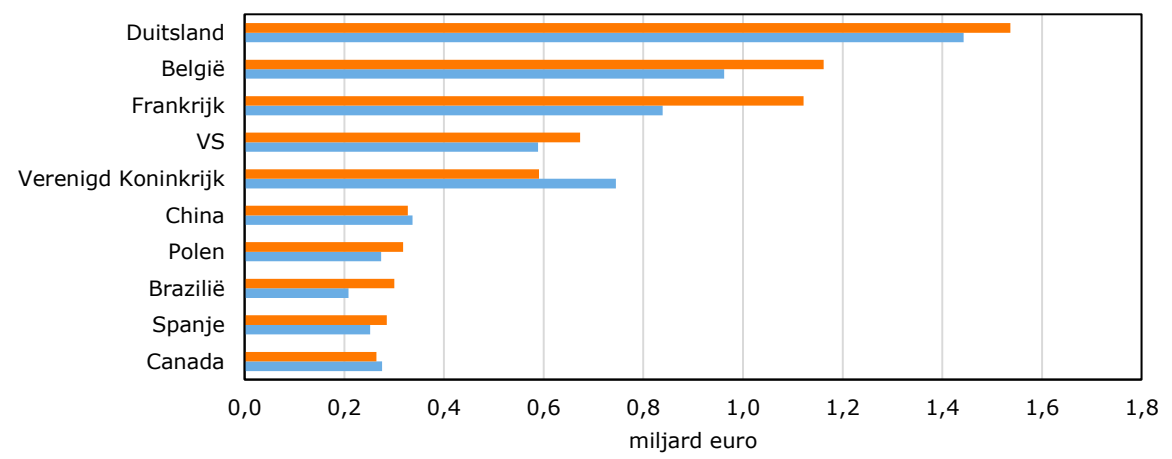

-2021 raming $=2020$

Figuur 5.3 Top tien bestemmingen export van landbouwgerelateerde goederen

Bron: CBS tot en met oktober 2021, raming november-december 2021 door CBS en Wageningen Economic Research.

Indien wordt gezuiverd voor wederuitvoer ontstaat een vergelijkbaar beeld met dezelfde landen (figuur 5.4), maar in een iets andere volgorde. Frankrijk is nu 
de tweede bestemming van Nederland in plaats van België; Canada en Brazilië staan nu hoger ten koste van Polen en Spanje (met relatief veel wederuitvoer).

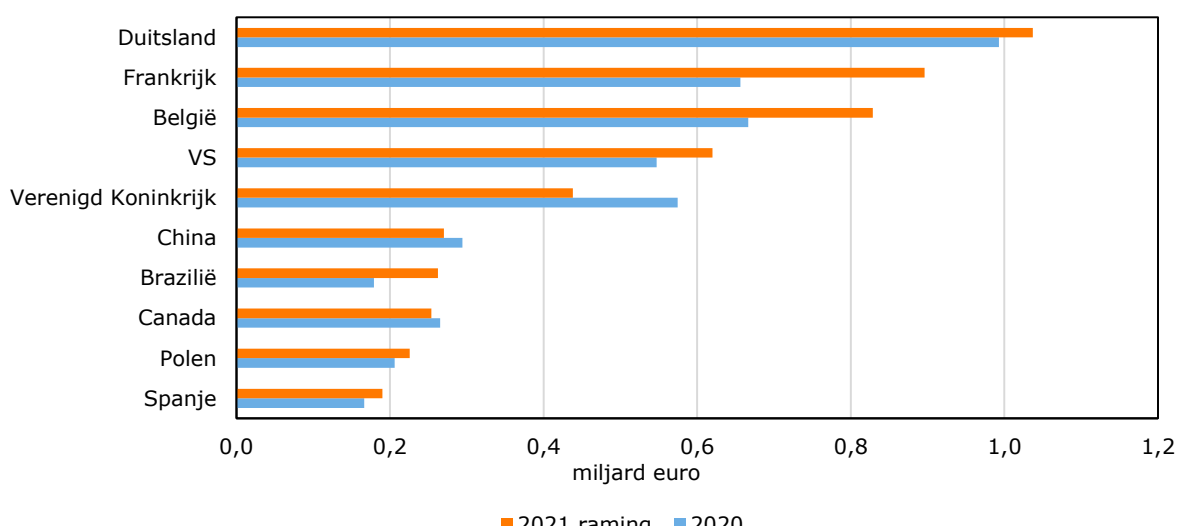

Figuur 5.4 Top tien bestemmingen export van Nederlandse landbouwgerelateerde goederen

Bron: CBS tot en met oktober 2021, raming november-december 2021 door CBS en Wageningen Economic Research.

De invoer van landbouwgerelateerde goederen (figuur 5.5) ligt op een veel lager niveau dan de export (figuur 5.3) en daarbij is een ander opvallend verschil dat de handel veel geconcentreerder is. Bijna de helft van alle import komt uit de buurlanden Duitsland en België. Uit Duitsland haalt Nederland in de eerste plaats veel landbouwmachines en op de tweede plaats kasmaterialen. Uit België komen overwegend kasmaterialen gevolgd door meststoffen.

De opvallendste verschillen met 2020 zijn te zien bij China (+47\%, vooral meer kasmaterialen en landbouwmachines), Frankrijk $(+32 \%$, vooral meer gewasbeschermingsmiddelen) en Denemarken (-29\%, vooral minder kasmaterialen). Frankrijk klimt in de rangschikking van leveranciers van plek vijf naar drie en dat heeft te maken met de bescheiden groei van de import uit het VK en de VS (beide $+3 \%$ ). China klimt van zeven naar vier en Denemarken verliest een plek. Het VK zakt zelfs drie plekken en is nu de zevende leverancier van landbouwgerelateerde goederen.

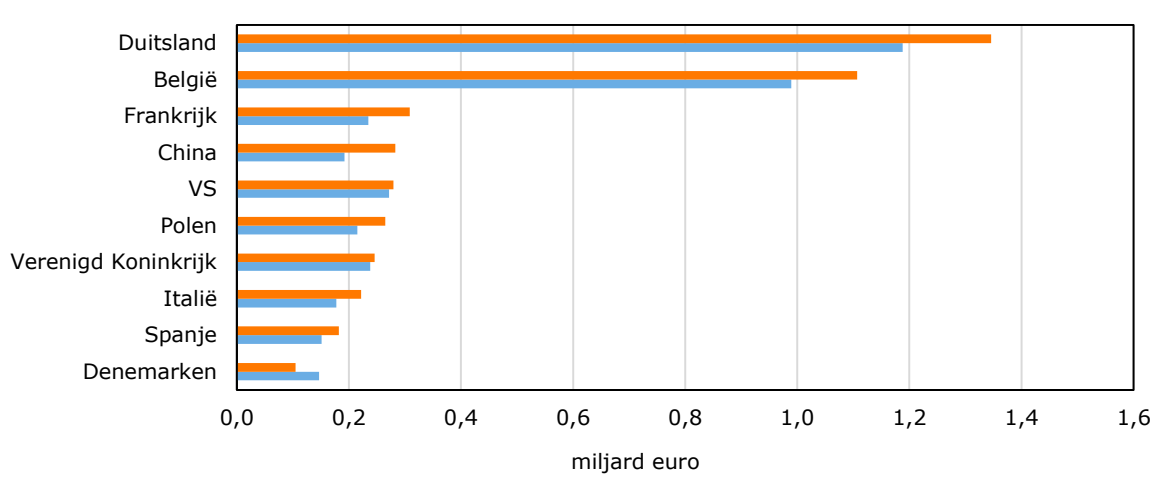

-2021 raming $=2020$

Figuur 5.5 Top tien herkomstlanden import van landbouwgerelateerde goederen

Bron: CBS tot en met oktober 2021, raming november-december 2021 door CBS en Wageningen Economic Research.

\subsection{Export van meststoffen neemt toe met $24 \%$}

Op productniveau zijn er van oudsher vier tertiaire landbouwgoederen met een hoge exportwaarde en zeven met een lage tot hele lage exportwaarde

(figuur 5.6). Zo is de export van landbouwmachines (25\%), meststoffen (21\%) machines voor de voedingsmiddelenindustrie (18\%) en kasmaterialen (15\%) samen goed voor $80 \%$ van de totale exportwaarde. In absolute zin heeft de grootste groei plaatsgevonden bij de export van meststoffen $(+0,4$ miljard euro of $24 \%$ groei). Dit betreft voor het overgrote deel een prijsstijging. Bij twee productgroepen kan een (lichte) afname worden genoteerd: de export van kasmaterialen en van sproeitoestellen nam met $1 \%$ af. 


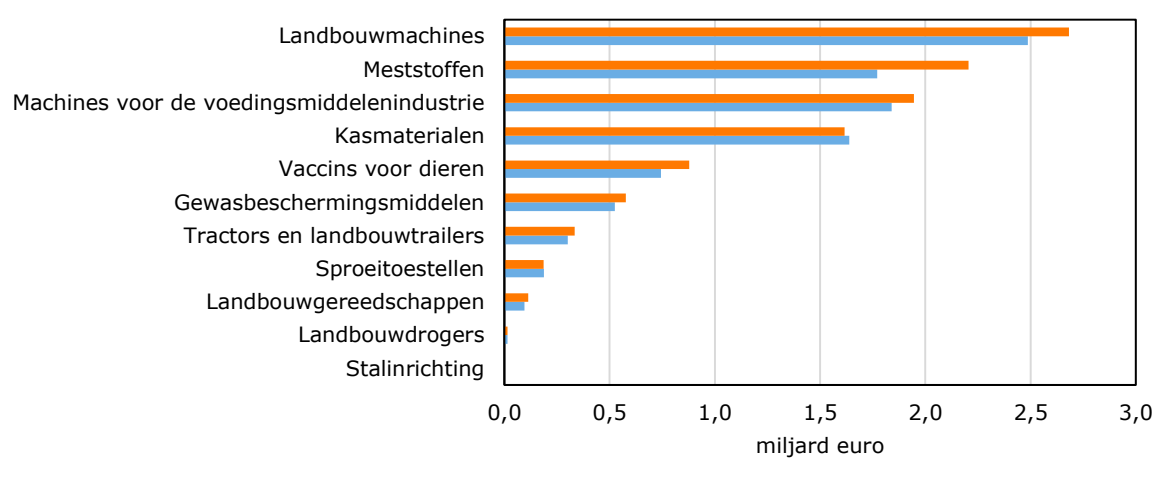

$=2021$ raming $=2020$

Figuur 5.6 Landbouwgerelateerde export naar productgroep

Bron: CBS tot en met oktober 2021, raming november-december 2021 door CBS en Wageningen Economic Research.

Indien wederuitvoer niet wordt meegerekend, dan blijft de top vier ongewijzigd (figuur 5.7). De export van deze goederen is namelijk voor het grootste deel van Nederlandse makelij. De nummer vijf van de totale export, vaccins voor dieren, zakt wel helemaal weg, omdat vrijwel alle export wederuitvoer betreft. Er zit ook relatief veel wederuitvoer bij andere goederen buiten de top vier, waardoor de dominantie van de top vier nog groter wordt na zuivering voor wederuitvoer. Het aandeel van landbouwmachines, machines voor de voedingsmiddelenindustrie, kasmaterialen en meststoffen is nu niet $80 \%$ maar $90 \%$ van het totaal.

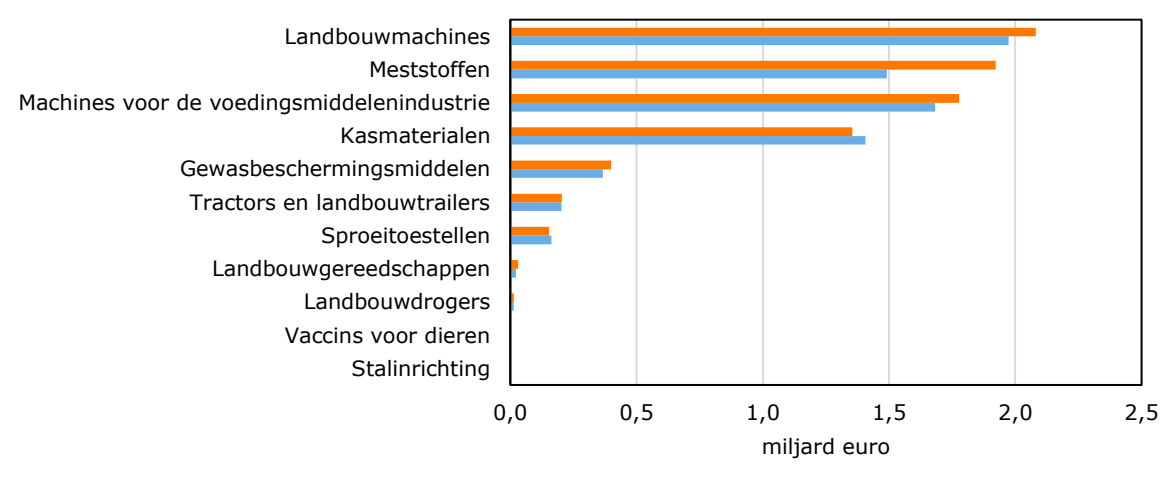

- 2021 raming $=2020$

Figuur 5.7 Landbouwgerelateerde export van Nederlandse makelij naar productgroep

Bron: CBS tot en met oktober 2021, raming november-december 2021 door CBS en Wageningen Economic Research.

Aan de invoerkant staan relatief veel landbouwmachines ( 1,4 miljard euro) en kasmaterialen ( 1,1 miljard) (figuur 5.8). Op enige afstand volgen meststoffen ( 0,8 miljard euro), gewasbeschermingsmiddelen $(0,7$ miljard), machines voor de voedingsmiddelenindustrie en tractors/landbouwtrailers (elk 0,5 miljard euro). De importwaarde van andere landbouwgerelateerde goederen is veel lager.

In vergelijking met 2020 valt op dat de invoer van meststoffen de import van gewasbeschermingsmiddelen is gepasseerd (van vier naar drie). De import van meststoffen groeide ook het hardst met $28 \%$ in 2021 (vooral volumegroei). Ook de import van landbouwmachines is met $19 \%$ sterk toegenomen. 


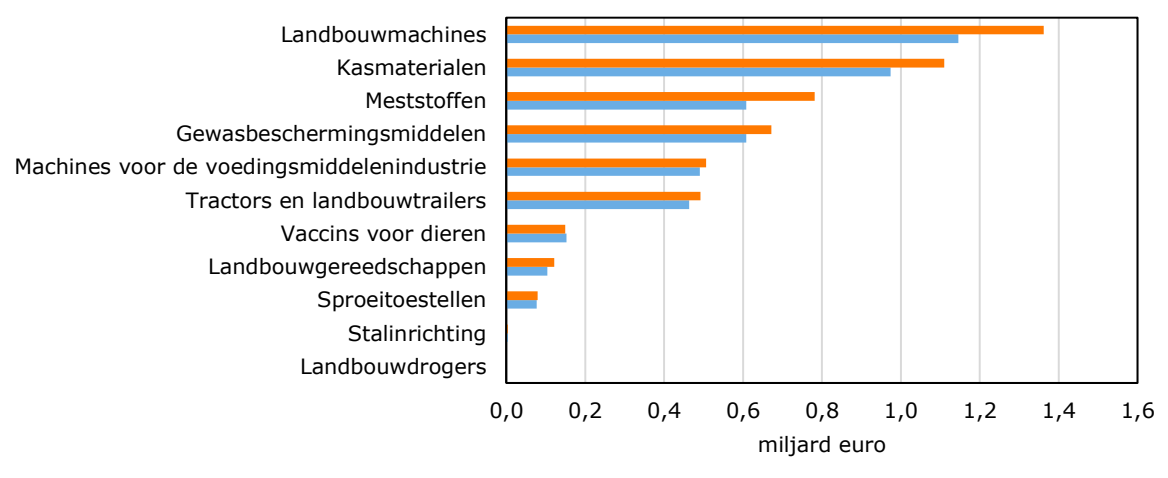

- 2021 raming $=2020$

Figuur 5.8 Landbouwgerelateerde import naar productgroep

Bron: CBS tot en met oktober 2021, raming november-december 2021 door CBS en Wageningen Economic Research.

\section{5 'Brede' landbouwexportverdiensten meer dan 50 miljard euro}

Ook voor de tertiaire of landbouwgerelateerde goederen kan worden vastgesteld hoeveel de export ervan oplevert voor de Nederlandse economie. Voor 2021 worden de exportverdiensten geraamd op 4,6 miljard euro. Inclusief de primaire en secundaire landbouwgoederen (paragraaf 2.4) komen de 'brede' landbouwexportverdiensten voor Nederland daarmee uit op 50,6 miljard euro.

Dat is een nieuw record en fors meer dan in 2019 en 2020 (toen bijna 47 miljard euro).

Voor de landbouwgerelateerde goederen zijn voor het jaar 2020 ook gegevens beschikbaar op goederenniveau (figuur 5.9). Daaruit blijkt dat Nederland het meest verdient aan de export van landbouwmachines (1,2 miljard euro), gevolgd door machines voor de voedingsmiddelenindustrie (1,0 miljard), meststoffen ( 0,9 miljard) en kasmaterialen ( 0,7 miljard). Aan alle overige tertiaire landbouwexport verdiende Nederland in 2020 ruim 0,5 miljard euro.

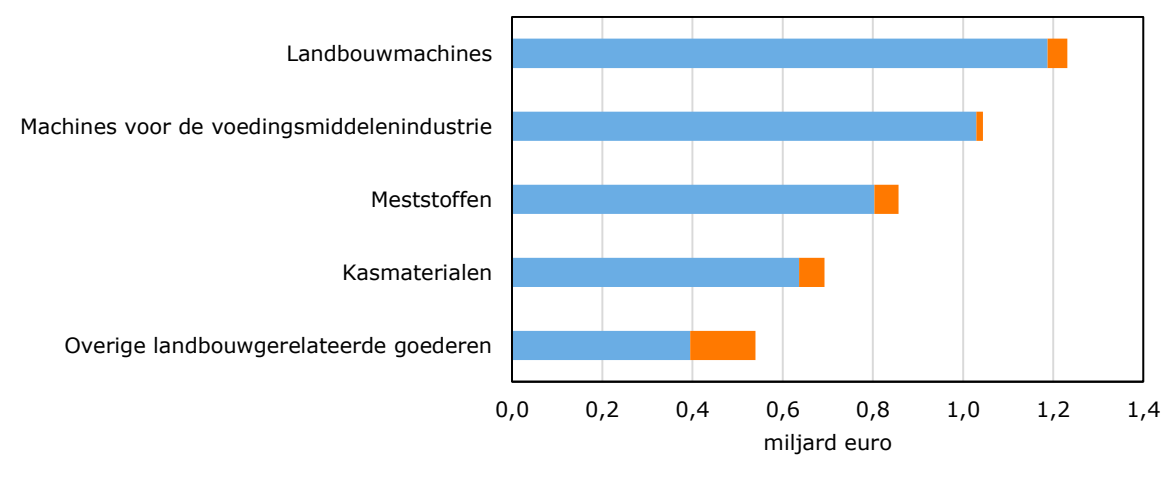

-Export Nederlandse makelij $\quad$ wederuitvoer

Figuur 5.9 Landbouwgerelateerde goederen met grootste exportverdiensten, 2020

Bron: CBS (waardeketenonderzoek).

Aan een gemiddelde euro exportwaarde van landbouwgerelateerde goederen verdient Nederland iets meer dan aan een gemiddelde euro exportwaarde van landbouwgoederen: 46 tegen 43 eurocent (figuur 5.10 in vergelijking met figuur 4.2). Bij de export van Nederlandse makelij (exclusief wederuitvoer) ligt het rendement ook hoger bij de landbouwgerelateerde goederen (62 tegen 60 eurocent). Het meest lucratief betreft de export van machines voor de voedingsmiddelenindustrie. Hieraan verdient Nederland 57 eurocent per euro exportwaarde. Indien we enkel kijken naar de in Nederland geproduceerde export (zonder wederuitvoer) dan blijken kasmaterialen toch het meest lucratief met 64 eurocent exportverdiensten per euro exportwaarde. 


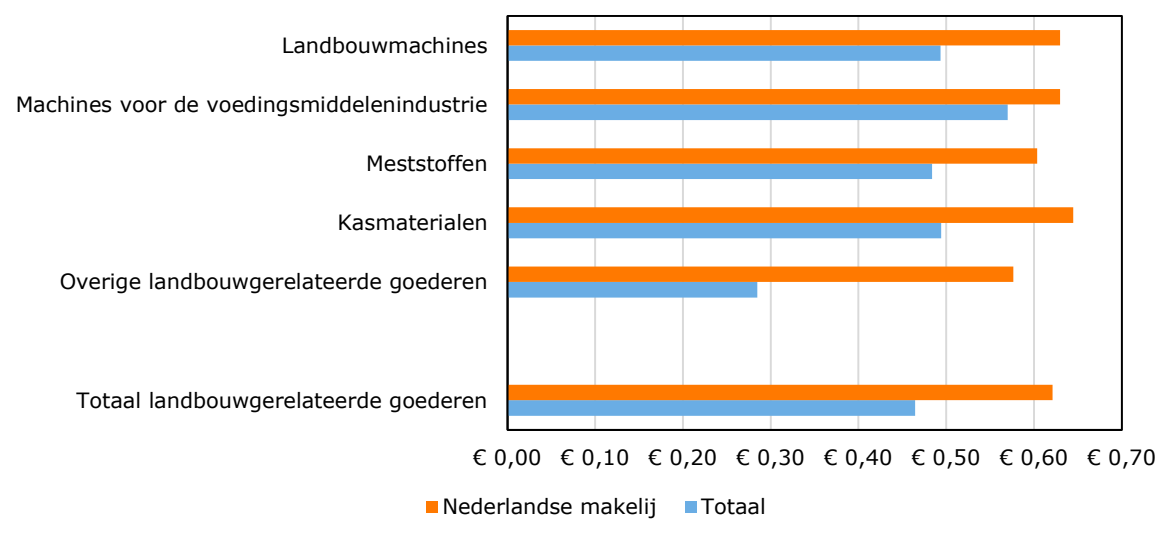

Figuur 5.10 Exportverdiensten per euro exportwaarde, 2020 Bron: CBS (waardeketenonderzoek).

Aan de meeste landbouwgerelateerde export is Nederland in de loop van de tijd steeds meer gaan verdienen. Bij drie groepen is de toename in exportverdiensten tussen 2015 en 2020 vergelijkbaar (figuur 5.11). De groei van de exportverdiensten was het grootst bij de landbouwmachines met een toename van 0,25 miljard euro, gevolgd door machines voor de voedingsmiddelenindustrie $(+0,21$ miljard) en kasmaterialen $(+0,17$ miljard). Bij de export van meststoffen zijn de verdiensten juist met een vergelijkbaar bedrag afgenomen (-0,21 miljard). Bij de som van alle overige landbouwgerelateerde goederen heeft er in deze periode nauwelijks ontwikkeling plaatsgevonden voor wat betreft de Nederlandse exportverdiensten $(+0,01$ miljard euro).

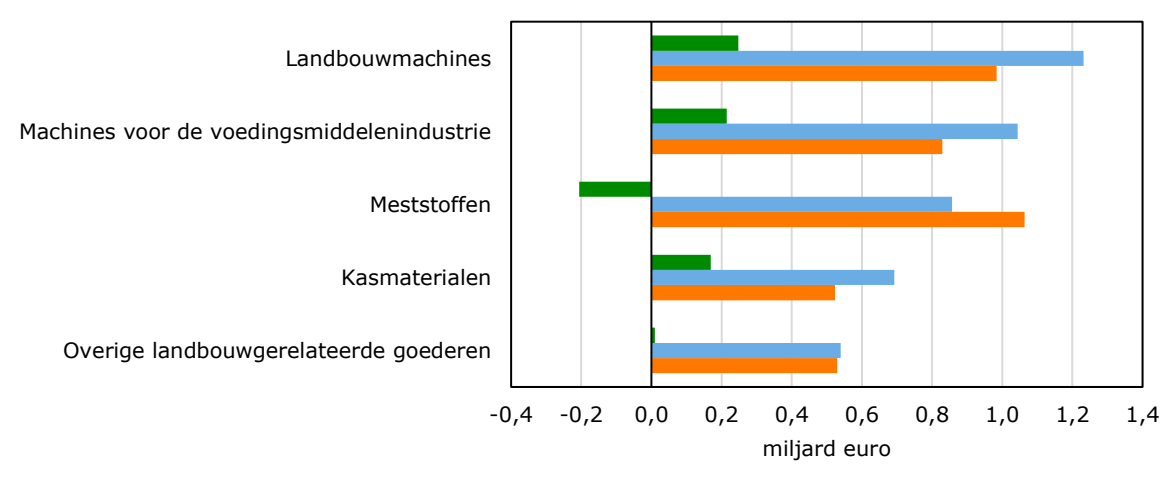

- Ontwikkeling $=2020 \quad-2015$

Figuur 5.11 Ontwikkeling exportverdiensten landbouwgerelateerde goederen, 2015-2020

Bron: CBS (waardeketenonderzoek). 


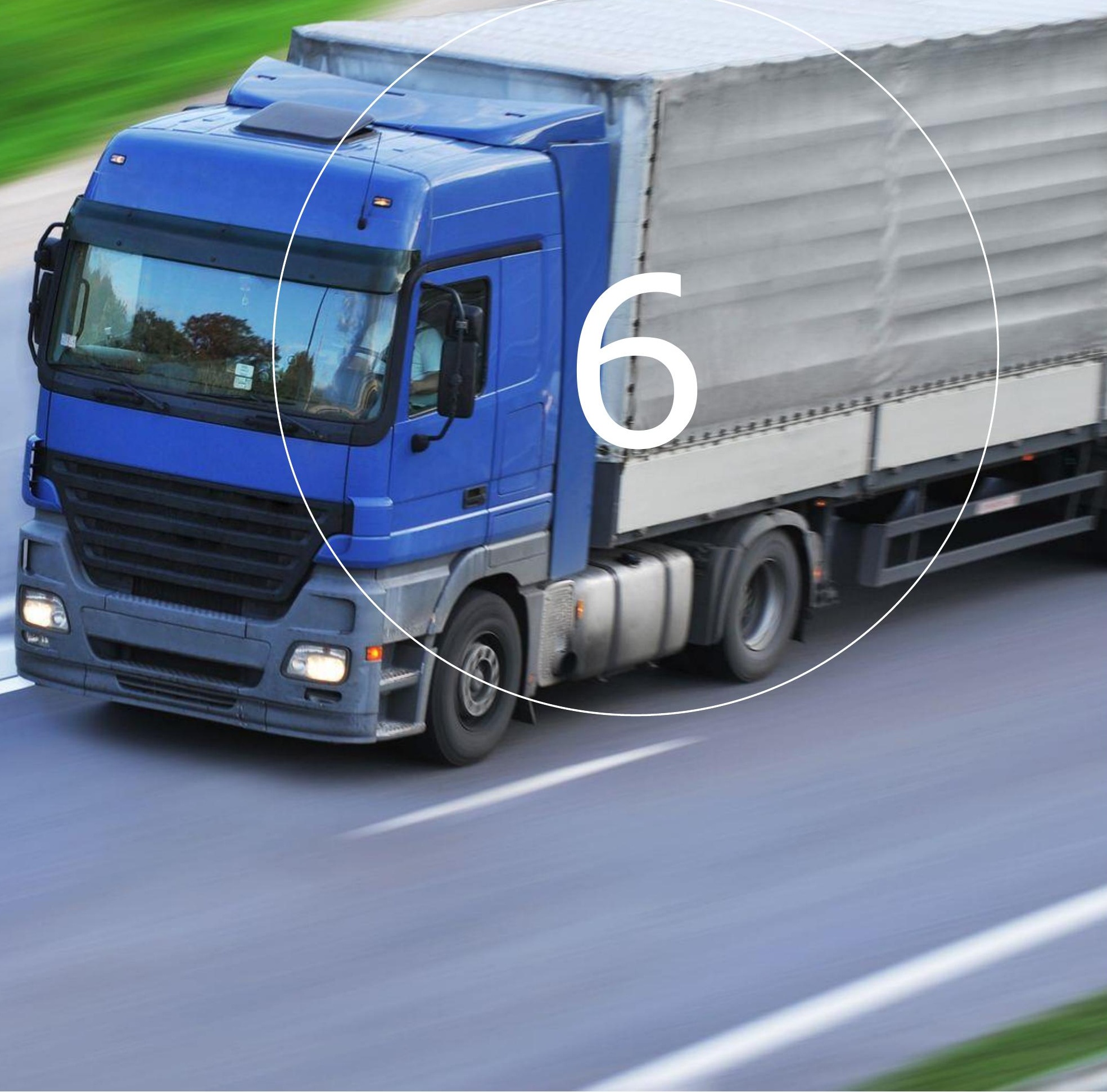




\section{Gevolgen van de Brexit}

\section{$6.1 \quad$ Inleiding}

Sinds 1 januari 2021 is met het in werking treden van de Handels- en Samenwerkingsovereenkomst (Trade and Cooperation Agreement, ofwel TCA) tussen de Europese Unie (EU) en het Verenigd Koninkrijk (VK) de Brexit formeel effectief. Ondanks deze formele effectiviteit, is Brexit in de praktijk pas afgerond in 2022. In 2022 zullen aan Britse kant namelijk nog veel maatregelen volgen die de landbouwexport van Nederland naar het VK zullen belemmeren. Het betreft diverse douaneformaliteiten en vele extra fytosanitaire en veterinaire controles ${ }^{2}$.

Op 31 januari 2020 had het VK de EU al formeel verlaten, waarna er een overgangsperiode volgde waarin het VK zich nog aan de Europese handelsregels hield. Hiermee wilde men verstoringen van de handel na de Brexit voorkomen en nieuwe handelsregels in een handelsakkoord kunnen vaststellen. Die transitie eindigde op 31 december 2020. Sinds 1 januari 2021 is het VK voor wat betreft de handel voor Nederland een 'derde land', een land buiten de EU.

De Britse economie is sterk geïntegreerd met die van de EU, met name in de landbouw, en de Brexit leidde tot aanzienlijke veranderingen in wettelijke regimes en handelspatronen. Het jaar 2021 is het eerste jaar van de veranderde handelsrelatie met het VK en het is vanuit dit perspectief relevant om te kijken naar de eerste ontwikkelingen voor wat betreft de Nederlandse landbouwhandel met het VK. De focus ligt daarbij op de periode vanaf 2015 omdat 2015 het beste referentiejaar is voor het maken van vergelijkingen. Het

\footnotetext{
2 Vanaf 1 januari 2022 is een volledig ingevulde Britse invoeraangifte verplicht, net als een vooraanmelding van de export van landbouwproducten. Ook vanaf die dag zullen uitgebreide goederencontroles gaan plaatsvinden bij de oversteek van goederen naar het VK en zijn er twee verschillende douaneprocessen (tijdelijke opslag en douaneaangifte vooraf) (RVO, 2021a). Vanaf 1 juli 2022 worden fytosanitaire controles ingevoerd voor alle plantaardige producten (met wel wat uitzonderingen waarbij geen controle nodig is, zie website NVWA).
}

is immers het laatste jaar vóór het Britse referendum over het al dan niet verlaten van de EU. In 2016 en de jaren erna ontstonden al de eerste 'préBrexit-effecten' op basis van onzekerheid door en anticipatie op een aanstaande Brexit (Jukema et al., 2021; Douch en Huw Edwards, 2021; Graziano et al., 2018).

Administratieve procedures en controles aan de grens

Naast de grote onzekerheid over de voorwaarden van de handelsrelatie vóór het sluiten van de TCA, heeft de Brexit ook na het ingaan van de TCA voor moeilijkheden gezorgd.

Ten eerste heeft de Brexit fysieke belemmeringen opgeworpen: waar goederen voorheen ongehinderd de grens tussen het VK en de EU konden passeren, moeten de goederen na de Brexit aangegeven worden bij de douane en formeel ingevoerd worden. Dergelijke administratieve procedures zorgen voor extra kosten voor handelaren. Ook kan dit vertraging opleveren, wat met name voor de bederfelijke producten een groot probleem vormt (Matthews, 2017; Cheptea et al., 2021). Bedrijven gaven na drie maanden TCA dan ook aan vooral last te hebben van de extra bureaucratie en vertragingen aan de grens, met name voor de bederfelijke producten (LNV, 2021a).

Bij de EU-import uit het VK zijn de EU-douanemaatregelen en veterinaire en fytosanitaire controles al volop in werking (ASD Group, 2021). De autoriteiten van het land van binnenkomst (Nederland in dit geval) controleren of importzendingen voldoen aan de eisen die de EU stelt (NAO, 2021). Controle is nodig om de gezondheid van mens, dier en plant te waarborgen en te

Dat gold overigens al voor de volgende goederen vanaf 1 januari 2021: high priority plants and plant products, high risk plants, planten van buiten de EU, CITES-producten en gebruikte machines. In de loop van 2022 worden ook steeds meer veterinaire controles (verplichte certificering en fysieke controles) ingevoerd (per 1 juli: vlees(producten) en dierlijke bijproducten; per 1 september: alle zuivelproducten; per 1 november: alle overige dierlijke producten) (NVWA, 2021a en 2021b). 
voorkomen dat er bijvoorbeeld ziekten en onveilige producten de EU in komen (NVWA, 2020a en 2020b). Zo zijn vrijwel alle planten en plantaardige producten certificaatplichtig bij export naar de EU. Een deel van deze producten is ook inspectieplichtig (NVWA, 2021c). Voor de Britse export naar de EU waren deze veranderingen aan de grens per 1 januari 2021 dus een feit.

Bij de export van de EU naar het VK worden de grenscontroles echter gefaseerd ingevoerd door het VK, omdat het VK meer tijd nodig heeft voor het opzetten van een grenscontrolesysteem (Evofenedex, 2021) (zie ook voetnoot 2). Deze vertragingen hebben in feite een overgangsperiode voor handelaren gecreëerd. Voor een deel van de landbouwgoederen geldt nu al dat exporteurs fytosanitaire certificaten aan moeten leveren en controles op hun goederen moeten ondergaan; dat zal voor steeds meer landbouwgoederen gaan gelden. Certificering van 'hoog risico' landbouwgoederen, zoals bomen, vaste planten en levende dieren, is al sinds 1 januari 2021 verplicht bij export van de EU naar het VK. Voor vrijwel alle andere landbouwproducten heeft het VK de controles uitgesteld. Voor 'laag risico' landbouwgoederen zoals snijbloemen, groenten en fruit is vanaf 1 juli 2022 een fytosanitair certificaat verplicht bij export van de EU naar het VK (RVO, 2021; NAO, 2021). Vanaf 1 juli 2022 kunnen transporten van heel wat landbouwgoederen (zoals vlees, eieren, zuivel, snijbloemen, groenten en fruit) alleen nog het VK binnenkomen via specifieke Britse havens met een grenscontrolepost (RVO, 2021b; NAO, 2021). Naast fytosanitaire maatregelen, zijn ook veterinaire maatregelen uitgesteld door het VK. Pas per 1 juli 2022 worden veterinaire gezondheidscertificaten gevraagd voor de uitvoer van vlees en vleesproducten van de EU naar het VK.

Handel in pootgoed verboden

Ten tweede werd de handel in enkele landbouwgoederen beperkt op fytosanitaire gronden, waar het verbod op de EU-import van pootgoed (met pootaardappelen als belangrijkste product) uit het VK het belangrijkste voorbeeld van is. Volgens de EU plantgezondheidswet- en regelgeving is vrije markttoegang voor pootaardappelen vanuit een 'derde land' alleen mogelijk indien dat 'derde land' zich blijvend committeert aan de fytosanitaire regels van de EU. Het VK wil zich niet committeren aan dergelijke afspraken en heeft als reactie eenzelfde verbod ingevoerd. Hierdoor staat het VK import van pootaardappelen uit EU-landen, waaronder Nederland, niet meer toe (LNV, 2021b; Dodde, 2021; Schouten, 2021). Naast pootaardappelen is de import van ander agrarisch teeltmateriaal ook verboden. Ook heeft het VK de import van een aantal soorten gehakt vanuit de EU verboden (EFA, 2021).

Invoerrechten en -quota voor extra-EU goederen

Ten derde gelden voor het VK in principe dezelfde invoerrechten en -quota als voor alle 'derde landen' sinds het VK geen lid meer is van de gemeenschappelijke markt. In de handelsovereenkomst tussen het VK en de EU (de TCA) is echter afgesproken dat er geen tarieven en quota gelden voor producten die binnen één van de twee partners (het VK of de EU) verkregen zijn. Dat betekent dat een product er geproduceerd of voldoende bewerkt moet zijn, wat per product bepaald wordt middels de zogenaamde oorsprongsregels. Om gebruik te kunnen maken van de TCA moeten bedrijven aantonen dat aan die regels is voldaan. Naast het feit dat dit administratieve rompslomp met zich mee brengt is het ook niet altijd mogelijk. Zo moeten over de goederen die bijvoorbeeld in Brazilië geproduceerd zijn, in Nederland ingepakt worden en vervolgens naar het VK geëxporteerd worden, sowieso invoerrechten betaald worden bij aankomst in het VK. Goederen kunnen op die manier dubbel getarifeerd worden: niet alleen bij invoer in Nederland, maar nogmaals bij invoer in het VK.

Van primaire landbouwgoederen is de oorsprong relatief eenvoudig te bepalen omdat de productie hiervan over het algemeen minder verweven is in (internationale) waardeketens, wat deels weer komt omdat ze vaak bederfelijk zijn. Nederland speelt, met de haven van Rotterdam en Schiphol, wel een grote rol in de internationale wereldhandel en transport. Veel goederen komen in Nederland aan, om vervolgens verder over Europa verspreid te worden, waaronder het VK. Eerder onderzoek toonde ook al aan dat de wederuitvoer naar het VK voor zo'n 50\% uit extra-EU import bestaat (Franssen et al., 2020a). Denk dan aan goederen als cacao, avocado's, bananen, soja en palmolie. Het zijn voornamelijk de wederuitvoerstromen van dit soort producten die problemen met de invoerrechten kunnen ondervinden sinds de Brexit. Hierdoor kunnen bedrijven er mogelijk voor kiezen handelsstromen te verleggen, en vaker rechtstreeks te importeren uit extra-EU-landen.

Ondanks de onzekerheden sinds het Brexit-referendum in 2016, en de daadwerkelijke belemmeringen van de nieuwe handelsrelatie sinds 2021 , is het VK nog steeds een belangrijke handelspartner voor de Nederlandse handel in landbouwgoederen. Uit hoofdstukken 3 bleek al dat het VK in 2021 de vierde 
exportbestemming voor onze landbouwgoederen is, de negende leverancier van landbouwgoederen voor Nederland en zelfs de derde bestemming voor wat betreft de verdiensten ${ }^{3}$ aan de landbouwexport. Daarbij moet wel worden aangetekend dat nu nog niet alle Brexit-effecten zichtbaar zijn. Vooral voor de export van Nederlandse makelij geldt dat er nog grote onzekerheid is over het effect van de invoering van veterinaire en fytosanitaire grenscontroles door het VK in 2022. In dit hoofdstuk wordt dieper ingegaan op de handel van landbouwgoederen met het VK, én de implicaties van de Brexit voor die verschillende handelsstromen.

\subsection{Landbouwimport uit het VK}

Tabel 6.1 toont de belangrijkste ontwikkelingen in de landbouwimport ${ }^{4}$ uit het VK sinds 2015. Tussen 2015 en 2021 is de landbouwimport uit het VK in waarde afgenomen; omdat de landbouwimport uit alle bestemmingen voortdurend is doorgegroeid, is het Britse aandeel in het totaal sterk afgenomen van 4,2\% in 2015 tot $2,6 \%$ in 2021 . Tussen 2015 en 2020 groeide de importwaarde nog wel, maar minder hard dan de landbouwimport uit andere landen.

In 2021 nam de landbouwimport uit het VK af, maar nam de totale goederenimport toe. Vooral de import van landbouwgoederen uit het VK heeft dus te lijden onder de Brexit. Naast de eerdergenoemde beperkingen voor een aantal specifieke goederen, spelen hier waarschijnlijk vooral de administratieve belemmeringen en veterinaire en fytosanitaire controles een rol. Alle voedingsproducten die uit het VK de EU binnenkomen, kregen hier in 2021 a mee te maken. Dit blijkt voor bedrijven een grote barrière te zijn ( $\mathrm{O}^{\prime}$ Carroll, 2021).

\footnotetext{
3 Waarde van een bruto-exportstroom minus het verbruik van geïmporteerde grondstoffen,
} halffabricaten en ondersteunende diensten.
Tabel 6.1 Landbouwimport uit het VK in perspectief

\begin{tabular}{lrrr} 
& $\mathbf{2 0 1 5}$ & $\mathbf{2 0 2 0}$ & $\mathbf{2 0 2 1}$ \\
\hline Landbouwimport uit het VK (mld euro) & 2,5 & 2,6 & 2,0 \\
\hline Goederenimport uit het VK (mld euro) & 20,6 & 20,0 & 25,3 \\
\hline & & & \\
\hline Aandeel VK in de totale landbouwimport (\%) & 4,2 & 3,7 & 2,6 \\
\hline Aandeel VK in de totale goederenimport (\%) & 5,5 & 4,7 & 4,9 \\
\hline & 100 & 102 & 79 \\
\hline Index landbouwimport uit het VK & 100 & 97 & 123 \\
\hline Index totale goederenimport uit het VK & & & \\
\hline & 100 & 117 & 129 \\
\hline Index totale landbouwimport & 100 & 114 & 138 \\
\hline Index totale goederenimport
\end{tabular}

Bron: CBS tot en met oktober 2021, raming november-december 2021 door CBS en Wageningen Economic

Research. Landbouwimport hier inclusief landbouwgerelateerde goederen.

\section{Brexit raakt de landbouwimport harder dan de niet-landbouw}

De totale goederenimport uit het VK is in tegenstelling tot de landbouwimport wel hard gestegen tussen 2020 en 2021 . Hier speelt vooral een prijseffect bij de niet-landbouwgoederen: voor een groot deel betreft de import uit het VK minerale brandstoffen en deze importwaarde beweegt mee met de olie- en gasprijzen die in de laatste maanden van 2021 hard zijn gestegen ten opzichte van een laag prijsniveau in 2020. Er is daarnaast ook een inhaaleffect: nietlandbouwgoederen zijn conjunctuurgevoeliger en hebben daarom meer last gehad van het coronajaar 2020 en vervolgens een sterker herstel gekend in 2021 dan de landbouwgoederen (zie verder hoofdstuk 7). Landbouwgoederen, en dan met name de voedingsmiddelen zijn essentiële goederen, waardoor de coronacrisis er minder invloed op had.

Op goederenniveau (tabel 6.2) is zichtbaar dat in 2021 fors minder dranken, zuivel, natuurlijke vetten en oliën, vlees en graan uit het VK werden ingevoerd dan in 2020. De grootse afname in absolute en relatieve zin betreft de invoer van vlees met een afname van 217 miljoen euro in 2020 naar 88 miljoen euro in $2021(-59 \%)$. Over de gehele periode $2015-2021$ is het beeld meer

${ }^{4}$ In dit hoofdstuk wordt voor de volledigheid de brede definitie van landbouw gehanteerd, inclusief landbouwgerelateerde goederen. Er zit nauwelijks verschil tussen de ontwikkeling inclusief en exclusief landbouwgerelateerde goederen, dus het algemene beeld is hetzelfde. 
wisselend met zowel sterke toenames (natuurlijke vetten en oliën, kasmaterialen) als afnames (zoals dranken, zuivel en vlees).

Tabel 6.2 Ontwikkeling importwaarde bij meest uit VK geïmporteerde goederen

\begin{tabular}{lrrrrr} 
& $\mathbf{2 0 1 5}$ & $\mathbf{2 0 2 0}$ & $\mathbf{2 0 2 1}$ & $\mathbf{2 0 1 5}-\mathbf{2 1}$ & \% \\
Voedingsbereidingen (overig) & 239 & 261 & 288 & 48 & 20 \\
\hline Dranken & 328 & 325 & 234 & -94 & -29 \\
\hline Zuivel en eieren & 192 & 187 & 139 & -52 & -27 \\
\hline Natuurlijke vetten en oliën & 78 & 197 & 131 & 53 & 68 \\
\hline Cacao(producten) & 115 & 115 & 126 & 12 & 10 \\
\hline $\begin{array}{l}\text { Bereidingen van graan, meel, } \\
\text { melk }\end{array}$ & 96 & 139 & 121 & 25 & 26 \\
\hline Vlees & 181 & 217 & 88 & -93 & -51 \\
\hline Resten voedselindustrie, veevoer & 93 & 96 & 84 & -9 & -10 \\
\hline Kasmaterialen & 50 & 46 & 69 & 19 & 39 \\
\hline Graan & 86 & 101 & 67 & -19 & -22 \\
\hline
\end{tabular}

Bron: CBS tot en met oktober 2021, raming november-december 2021 door CBS en WUR. Landbouwimport hier inclusief landbouwgerelateerde goederen.

\subsection{Landbouwexport naar het VK}

Tabel 6.3 toont de belangrijkste ontwikkelingen van de landbouwexport naar het VK sinds 2015. Tussen 2015 en 2021 is de waarde van de landbouwexport ongeveer op hetzelfde niveau gebleven. Omdat de totale landbouwexport voortdurend doorgroeide, is het Britse aandeel in de totale landbouwexport afgenomen van $10,0 \%$ in 2015 tot $7,9 \%$ in 2021 . De export van landbouwgoederen is wel nog steeds relatief sterk gericht op het VK: het VKaandeel blijft hoger bij de landbouwgoederen dan bij de totale goederenexport.

Na de Brexit is het VK minder belangrijk geworden als afnemer van landbouwgoederen

Sinds 2015 is de landbouwexport naar het VK met $2 \%$ in waarde gestegen en de totale goederenexport naar het VK met 4\%. Dat zijn veel lagere groeipercentages dan bij de totale landbouwexport (28\%) en de totale goederenexport (38\%). Zoals bij de landbouwimport, geldt ook voor de export dat de handelaren te maken krijgen met extra administratieve procedures en kosten, controles, en mogelijke invoerrechten en -quota. De controles en administratieve zaken zijn echter nog niet geheel van toepassing op de Nederlandse export: het VK heeft een deel van de maatregelen en controles uitgesteld tot 2022 (zie verder paragraaf 6.5).

Dit is echter niet het hele verhaal. De twee handelsstromen binnen de landbouwexport, Nederlandse makelij en wederuitvoer, reageren beiden hee anders op de genoemde problemen (zie paragraaf 6.4)

Tabel 6.3 Landbouwexport naar het VK in perspectief

\begin{tabular}{lrrr} 
& 2015 & 2020 & 2021 \\
\hline Landbouwexport naar het VK (mld. euro) & 9,0 & 9,3 & 9,1 \\
\hline Goederenexport naar het VK (mld. euro) & 36,5 & 34,9 & 38,1 \\
\hline & & & \\
\hline Aandeel in VK in totale landbouwexport (\%) & 10,0 & 8,8 & 7,9 \\
\hline Aandeel VK in totale goederenexport (\%) & 8,7 & 7,2 & 6,6 \\
\hline & 100 & 103 & 102 \\
\hline Index landbouwexport naar het VK & 100 & 96 & 104 \\
\hline Index goederenexport naar het VK & & & \\
\hline & 100 & 117 & 128 \\
\hline Index totale landbouwexport & 100 & 115 & 138 \\
\hline Index totale goederenexport & & & \\
\hline
\end{tabular}

Bron: CBS tot en met oktober 2021, raming november-december 2021 door CBS en WUR. Landbouwexport hier inclusief landbouwgerelateerde goederen.

De daling in exportwaarde van de landbouwgoederen was het grootst in januari en februari 2021. Dat komt deels doordat het handelsverdrag pas eind december afgesloten werd: bedrijven zaten in onzekerheid over onder welke voorwaarden ze hun goederen vanaf januari moesten verhandelen, waardoor sommigen vlak voor 2021 nog voorraden aanlegden (ONS, 2021a). Anderzijds ging er in die twee maanden veel bederfelijk voedsel verloren aan de grens door problemen met de invoer (Wright, 2021). In de eerste maanden van 2021 was er dus minder export naar het VK, maar dat trok weer aan vanaf maart en april. Daarbij spelen ook hogere prijzen in die periode een rol. 
Op productniveau is er een wisselend beeld voor de export van de belangrijkste landbouwgoederen naar het VK in 2021 (tabel 6.4). Een grote positieve uitschieter betreft de sierteelt waarvan de exportwaarde in 2021 met $44 \%$ ( +514 miljoen euro) gestegen is. Daarbij speelt vooral een prijseffect: bloemen en planten zijn fors duurder geworden in 2021 (Floridata, 2021). De positieve bijdrage van de sierteelt aan de exportprestaties met bestemming VK is groot. Zonder groei bij de sierteelt was de landbouwexport naar het VK niet met $1 \%$ afgenomen in 2021 , maar met $7 \%$. Bij de andere landbouwproducten zijn de verschillen met 2020 een stuk kleiner.

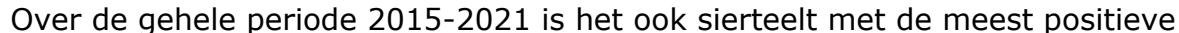
ontwikkeling $(+63 \%)$, gevolgd door natuurlijke vetten en oliën $(+36 \%)$ en dranken (+24\%). De export van vlees en groenten nam met respectievelijk $18 \%$ en $13 \%$ af ten opzichte van 2015 , het jaar vóór het Britse referendum.

Tabel 6.4 Ontwikkeling exportwaarde bij meest naar het VK geëxporteerde goederen ( $\mathrm{mln}$. euro)

\begin{tabular}{|c|c|c|c|c|c|c|c|}
\hline & 2015 & 2020 & 2021 & $\begin{array}{r}2015- \\
21\end{array}$ & $\%$ & $\begin{array}{r}2020- \\
21\end{array}$ & $\%$ \\
\hline Sierteelt & 1.028 & 1.160 & 1.674 & 647 & 63 & 514 & 44 \\
\hline Vlees & 1.298 & 1.074 & 1.068 & -230 & -18 & -6 & -1 \\
\hline Groenten & 887 & 671 & 769 & -118 & -13 & 98 & 15 \\
\hline Dranken & 645 & 847 & 801 & 155 & 24 & -46 & -5 \\
\hline Voedingsbereidingen (overig) & 581 & 577 & 553 & -28 & -5 & -25 & -4 \\
\hline $\begin{array}{l}\text { Bereidingen van graan, meel, } \\
\text { melk }\end{array}$ & 632 & 564 & 552 & -81 & -13 & -12 & -2 \\
\hline $\begin{array}{l}\text { Resten voedselindustrie, } \\
\text { veevoer }\end{array}$ & 513 & 413 & 435 & -77 & -15 & 22 & 5 \\
\hline Natuurlijke vetten en oliën & 277 & 406 & 376 & 99 & 36 & -30 & -7 \\
\hline Cacao(producten) & 375 & 422 & 358 & -17 & -5 & -64 & -15 \\
\hline Bereidingen van groenten en & 308 & 338 & 323 & 15 & 5 & -15 & -4 \\
\hline
\end{tabular}

fruit

Bron: CBS tot en met oktober 2021, raming november-december 2021 door CBS en Wageningen Economic

Research. Landbouwexport hier inclusief landbouwgerelateerde goederen.

${ }^{5}$ Bij Office for National Statistics (ONS) zijn enkel cijfers tot en met oktober 2021 beschikbaar. Daarom is bij deze berekeningen enkel gekeken naar de periode januari-oktober voor de jaren 2018, 2019, 2020 en 2021.
De handel met de EU (en ook Nederland) is belangrijk voor het VK De Britse landbouw is sterk geïntegreerd in de interne markt van de EU. Het VK is een netto-importeur van voedingsmiddelen uit de EU en een belangrijke bestemmingsmarkt voor de EU-export van voedingsmiddelen (Cheptea et al., 2021). In totaal komt $30 \%$ van het voedsel dat in het VK wordt geconsumeerd uit de 27 EU-lidstaten. Meer specifiek zijn Nederland, Ierland en Frankrijk de grootste buitenlandse leveranciers van het VK (Choi et al., 2021; Cheptea et al., 2021)

Van alle handelspartners was het VK in 2021 de vierde exportbestemming voo landbouwgoederen van Nederland. In 2020 was het VK nog de derde exportbestemming. Vanuit Brits perspectief was Nederland in 2021 het tweede belangrijkste land van herkomst voor landbouwimport, enkel voorafgegaan door Frankrijk. In 2018, 2019 en 2020 haalde het VK nog de hoogste waarde aan landbouwgoederen uit ons land (ONS, 2021b). ${ }^{5}$

\subsection{Wederuitvoer en export van Nederlandse makelij}

Een belangrijk onderscheid in de exportstatistieken betreft wederuitvoer van producten van buitenlandse makelij versus export van goederen van Nederlandse makelij. In de eerste plaats is het zo dat de Nederlandse economie per euro export circa vier keer meer verdient aan de export van Nederlandse makelij dan aan wederuitvoer. ${ }^{6} \mathrm{Bij}$ de export naar het VK specifiek, leverde de export van goederen van Nederlandse makelij de Nederlandse economie circa 56 eurocent per euro export op in 2020, tegenover 14 eurocent per euro wederuitvoer. In de tweede plaats is het onderscheid zeer relevant in de Brexit-context. Het is namelijk zo dat het VK en de EU geen invoerrechten op elkaars goederen heffen indien bedrijven kunnen aantonen dat de verhandelde producten in het VK of de EU geproduceerd zijn. Op de goederen die daarbuiten vervaardigd zijn, kunnen wel tarieven worden geheven. De export van goederen die niet kunnen voldoen aan de oorsprongsregels kreeg dus vanaf 1 januari 2021 te maken met invoertarieven. Dat betreft een deel van de Nederlandse wederuitvoer naar het VK. De

6 De Statline-tabel 'Verdiensten en arbeidsvolume; uitvoerstromen, landen' bevat op het moment van schrijven gegevens tot en met 2019. De cijfers voor 2020 worden later toegevoegd aan de tabel, maar worden hier in de tekst al vermeld. 
goederen die niet onder de handelsovereenkomst vallen, komen onder dezelfde voorwaarden binnen als handel uit de rest van de wereld (most favoured nation voorwaarden; WTO, 2021). Die tarieven variëren, en kunnen ook 0\% zijn. De export van Nederlandse makelij heeft veel minder last van deze regel: voor deze producten geldt dat ze per definitie in de EU (Nederland)

vervaardigd of verwerkt zijn, maar ook dat moet aangetoond worden met de benodigde documenten.

De wederuitvoer van landbouwgoederen naar het VK lag in $202133 \%$ lager dan in 2020 (tabel 6.5). Over de gehele periode vanaf 2015 gemeten ligt de wederuitvoer van landbouwgoederen naar het VK $21 \%$ onder het niveau van 2015. De wederuitvoer van alle goederen met bestemming VK is zelfs $26 \%$ lager dan in 2015. De wederuitvoer van landbouwgoederen naar alle bestemmingen in 2021 ligt juist 40\% hoger dan in 2015; voor alle goederen is dat zelfs $42 \%$. Voor de landbouwproducten geldt dat de volledige afname in 2021 heeft plaatsgevonden, bij de overige goederen was de afname al iets eerder ingezet.

Aangezien de wederuitvoer van landbouwgoederen naar het VK in vergelijking met wederuitvoer naar andere landen of in vergelijking met de uitvoer van Nederlandse makelij naar het VK sterk is afgenomen, ligt het voor de hand dat de instelling van de invoertarieven per 1 januari 2021 daarmee te maken heeft. Wederuitvoer betreft namelijk per definitie buitenlandse makelij en komt vaak van buiten de EU, waardoor het lastiger wordt om te voldoen aan de oorsprongsregels van het TCA. Bij de landbouwgoederen kan gedacht worden aan koffie en thee, cacao en fruitsoorten als bananen, mango's en avocado's. Handelaren kunnen deze stromen soms eenvoudig verleggen: ze hoeven niet per se via Nederland naar het VK te gaan, ze kunnen ook direct uitvoeren naar het VK. Wanneer er dan extra barrières opgeworpen worden, kan het efficiënter zijn om Nederland over te slaan. Dit lijkt dan ook te gebeuren voor een deel van de wederuitvoer die voorheen via Nederland naar het VK ging (Smid en Frankena, 2021). Naast invoertarieven hebben wederuitvoerstromen ook tweemaal te maken met fytosanitaire controles en administratieve procedures: bij invoer in Nederland en bij invoer in het VK. Dat kan meespelen om de goederenstromen niet meer via Nederland te laten lopen, maar direct naar het VK te transporteren.
Tabel 6.5 Wederuitvoer landbouwgoederen naar het VK in perspectief

\begin{tabular}{lrrr} 
& 2015 & 2020 & 2021 \\
\hline Landbouwwederuitvoer naar het VK (mld. euro) & 2,2 & 2,6 & 1,7 \\
\hline Goederenwederuitvoer naar het VK (mld euro) & 17,6 & 17,1 & 13,1 \\
\hline & & & \\
\hline Aandeel in VK in totale landbouwwederuitvoer (\%) & 9,6 & 8,7 & 5,5 \\
\hline Aandeel VK in totale goederenwederuitvoer (\%) & 10,0 & 7,8 & 5,2 \\
\hline & & & \\
\hline Index landbouwwederuitvoer naar het VK & 100 & 118 & 79 \\
\hline Index goederenwederuitvoer naar het VK & 100 & 97 & 74 \\
\hline & & & \\
\hline Index totale landbouwwederuitvoer & 100 & 131 & 140 \\
\hline Index totale goederenwederuitvoer & 100 & 124 & 142 \\
\hline
\end{tabular}

Bron: CBS tot en met oktober 2021, raming november-december 2021 door CBS en Wageningen Economic

Research. Landbouwexport hier inclusief landbouwgerelateerde goederen.

Tegenover deze afname van de wederuitvoer staat juist een toename van de landbouwexportwaarde van Nederlandse makelij naar het VK (tabel 6.6). Deze ligt in 2021 11\% hoger dan in 2020 en 9\% hoger dan in 2015. Die groei komt wederom voornamelijk door een prijsstijging van sierteeltproducten.

Hoewel de landbouwexport van Nederlandse makelij naar het VK in 2021 veel beter heeft gepresteerd dan de import uit het VK of de wederuitvoer naar het VK, waren de prestaties minder dan bij de niet-landbouwgoederen van Nederlandse makelij. Zo is sinds 2015 de totale goederenexport van Nederlandse makelij naar het VK met $34 \%$ in waarde gestegen, de totale landbouwexport van Nederlandse makelij met $24 \%$ en de totale goederenexport van Nederlandse makelij zelfs met $35 \%$. Het VK-aandeel in de totale landbouwexport van Nederlandse makelij is wel iets gestegen in 2021 (van 8,8 naar 8,9\%). 
Tabel 6.6 Landbouwexport van Nederlandse makelij naar het VK in perspectief

\begin{tabular}{lrrr} 
& 2015 & 2020 & 2021 \\
$\begin{array}{l}\text { Landbouwexport van Nederlandse makelij naar het } \\
\text { VK (mld. euro) }\end{array}$ & 6,8 & 6,7 & 7,4 \\
\hline $\begin{array}{l}\text { Goederenexport van Nederlandse makelij naar het } \\
\text { VK (mld. euro) }\end{array}$ & 18,9 & 17,8 & 25,0 \\
\hline & & & \\
\hline $\begin{array}{l}\text { Aandeel VK in totale landbouwexport van } \\
\text { Nederlandse makelij (\%) }\end{array}$ & 10,1 & 8,8 & 8,9 \\
\hline $\begin{array}{l}\text { Aandeel VK in totale goederenexport van } \\
\text { Nederlandse makelij (\%) }\end{array}$ & & 6,7 & 7,7 \\
\hline & 100 & 98 & 109 \\
\hline $\begin{array}{l}\text { Index landbouwexport van Nederlandse makelij naar } \\
\text { het VK }\end{array}$ & 100 & 94 & 134 \\
\hline $\begin{array}{l}\text { Index goederenexport van Nederlandse makelij naar } \\
\text { het VK }\end{array}$ & 100 & 112 & 124 \\
\hline $\begin{array}{l}\text { Index totale landbouwexport van Nederlandse } \\
\text { makelij }\end{array}$ & 100 & 109 & 135 \\
\hline $\begin{array}{l}\text { Index totale goederenexport van Nederlandse } \\
\text { makelij }\end{array}$ & & & \\
\hline
\end{tabular}

Bron: CBS tot en met oktober 2021, raming november-december 2021 door CBS en Wageningen Economic

Research. Landbouwexport hier inclusief landbouwgerelateerde goederen.

De producten van Nederlandse makelij zijn mogelijk minder goed te vervangen door substituten uit het VK zelf of uit andere landen, dan bij de wederuitvoer het geval is. Bovendien zijn de fytosanitaire controles en administratieve procedures nog maar ten dele van toepassing op de export naar het VK. De genoemde problemen spelen de landbouwexport mogelijk wel al in beperkte mate parten: de totale export van Nederlandse makelij naar het VK groeide in 2021 namelijk veel harder dan de landbouwgoederen van Nederlandse makelij naar het VK.

Op productniveau is er voor de belangrijkste agrarische exportgoederen van Nederlandse makelij een overwegend positief beeld in 2021 waarneembaar met onder andere forse toenames bij de exportwaarde van vlees, bereidingen van groente en fruit en dranken. Echter, bijna twee derde van de waardegroei in 2021 is toe te schrijven aan exportgroei van sierteelt van Nederlandse makelij, met name door een sterk stijgende bloemenprijs. Over de gehele periode 2015-2021 is er een wat meer wisselend beeld met onder andere afgenomen export van groenten en vlees.

Voor de wederuitvoer van landbouwgoederen met bestemming VK geldt voor het overgrote deel een forse afname van de exportwaarde in 2021. Zo is de wederuitvoerwaarde van fruit, resten voedselindustrie/veevoer, vlees, voedingsbereidingen, bereidingen van groente en fruit en cacao(producten) in een jaar tijd circa gehalveerd. Vooral fruit, cacao en soja zijn goederen die vooral vanuit buiten de EU aangevoerd worden, waardoor ze niet kwalificeren voor de oorsprongsregels en tweemaal getarifeerd kunnen worden. De wederuitvoer van sierteelt is in 2021 wel in waarde toegenomen wat er op kan duiden dat het prijseffect hier sterker is geweest dan de afname in volume.

\subsection{Samenvattend beeld en vooruitblik}

De landbouwhandel met het VK over de gehele periode 2015-2021 heeft duidelijk minder gepresteerd dan de totale landbouwhandel (alle bestemmingen), resulterend in sterk afnemende Britse aandelen in de totale Nederlandse landbouwhandel, met name in 2021, het eerste jaar van de effectieve Brexit. Dat geldt met name voor wederuitvoer en landbouwimport. Het aandeel van de landbouwexport van Nederlandse makelij is ook duidelijk afgenomen sinds 2015, maar is wel licht gestegen in 2021 ten opzichte van 2020. Ondanks de afnemende aandelen is het VK nog steeds een belangrijke handelspartner voor Nederland voor wat betreft landbouwgoederen, waarbij tegelijkertijd ook het VK afhankelijk blijft van Nederland als agrarische leverancier.

De landbouwhandel met het VK werd op een aantal manieren bemoeilijkt sinds januari 2021, toen de Brexit een feit werd. Ten eerste gingen er een aantal algemene handelsbeperkingen in werking, waaronder importverboden op specifieke goederen. Ten tweede is de landbouwhandel als gevolg van de Brexit onderworpen aan douaneformaliteiten en veterinaire en fytosanitaire controles. Dit zorgt bij de EU-import uit het VK nu al voor extra (fytosanitaire) 
controles en administratieve verplichtingen, welke mogelijk een rol speelden in de afgenomen Nederlandse import van landbouwgoederen uit het VK in 2021.

Voor de EU-export geldt echter dat de Britse grenscontroles grotendeels pas in 2022 van kracht zullen zijn. In welke mate de landbouwexport van

Nederlandse makelij in 2021 last heeft gehad van de grenscontroles is nog niet volledig te beoordelen op basis van een eenvoudige trendanalyse. Het feit dat deze exportstroom in 2021 niet daalde, maar juist toenam, ten opzichte van 2020 heeft wellicht te maken met het feit dat het VK vele grenscontroles op de EU-export van voedingsproducten heeft uitgesteld tot medio 2022 . Het is goed mogelijk dat de landbouwexport van Nederlandse makelij in 2022 nog flink last zal krijgen van de Brexit-obstakels die pas dan zullen gaan optreden (extra douaneformaliteiten, fytosanitaire en veterinaire controles). In 2022 zal dus veel meer duidelijkheid komen over het totale Brexit-effect op de Nederlandse landbouwexport naar het VK.

Het derde probleem dat opgeworpen werd door de nieuwe handelsrelatie met het $\mathrm{VK}$, is de mogelijkheid van importtarieven. Om dubbele tarieven en dubbele grensformaliteiten te vermijden, kan ervoor gekozen worden de wederuitvoerstromen niet meer via Nederland te verhandelen, maar direct in het VK in te voeren. De grote daling van de wederuitvoer naar het VK duidt erop dat dit ook daadwerkelijk gebeurde in 2021. Het is goed mogelijk dat de importtarieven ook negatieve gevolgen hebben gehad voor de Nederlandse import uit het VK voor zover het gaat om Britse wederuitvoer van producten van buiten de EU. Dit kan mogelijk deels verklaren waarom de import uit het VK in 2021 ook hard is geraakt.

Naast de reeds genoemde ontwikkelingen speelde er een mogelijk anticipatieeffect in 2021, omdat, zoals beschreven, pas in 2022 uitgebreide controles plaatsvinden op de landbouwexport naar het VK. Een dergelijk exportverhogend effect is echter hooguit denkbaar voor (lang) houdbare producten en een dergelijke trend is voor deze goederen nog niet zichtbaar in de data (tot en met oktober 2021). Ook heeft de coronapandemie natuurlijk effect gehad op de landbouwhandel met het VK, maar het lijkt heel lastig om dat effect apart van het Brexit-effect te kwantificeren.

Tot slot is er mogelijk nog een ander toekomstig Brexit-effect. Een belangrijke motivatie voor de Britten om de EU te verlaten was namelijk dat zij hun eigen regels wilden kunnen bepalen, ook met betrekking tot internationale handel Door los te breken van de EU zijn zij in principe in staat om af te wijken van Europese regels, bijvoorbeeld met betrekking tot productie of internationale handel. Omdat dit ze vervolgens mogelijk een concurrentievoordeel kan opleveren is de EU daar niet blij mee. Daarnaast kunnen afwijkende regels zorgen voor additionele kosten voor Europese exporteurs, wanneer zij vervolgens aan twee verschillende standaarden moeten voldoen (Franssen et al., 2020b; Elms, 2020). Vooralsnog hebben de blokken afgesproken zich aan gelijkwaardige standaarden te houden (level playing field). Daarmee worden niet alleen hogere productiekosten voor exporteurs voorkomen, maar ook de kosten die kunnen ontstaan uit mogelijke oneerlijke concurrentie of de daarop volgende geschillenbeslechting. Indien er namelijk een oneerlijk concurrentievoordeel ontstaat door het afwijken van normen door de ene partij (tenzij gegrond op legitieme gezondheidsredenen) dan kan de andere partij het recht hebben om te straffen middels bijvoorbeeld invoerheffingen, met alle gevolgen van dien. 


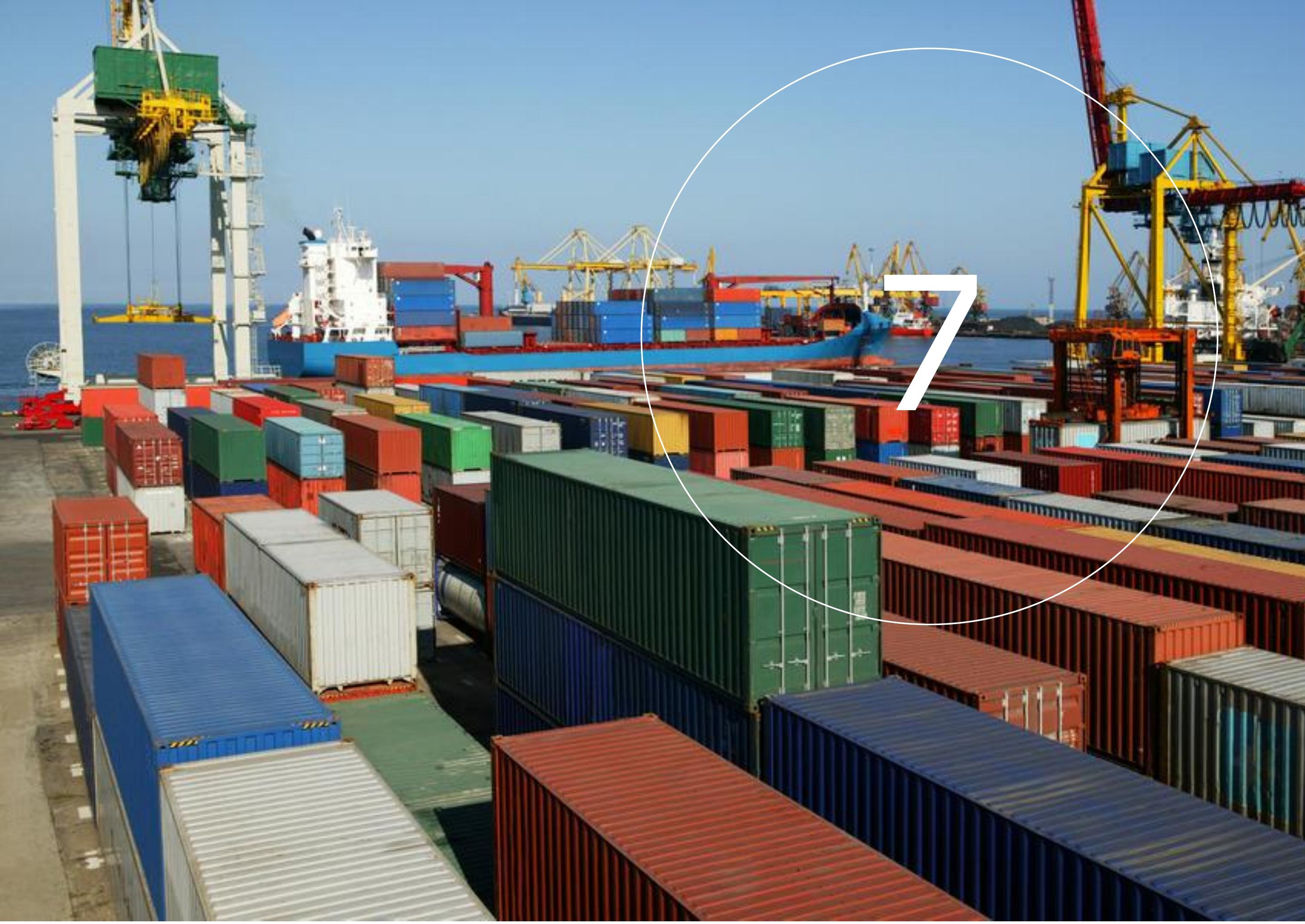




\section{De coronapandemie en de gevolgen voor de handel}

\section{$7.1 \quad$ Inleiding}

Sinds begin 2020 houdt de coronapandemie de wereld in haar greep. In fases en in meer of mindere mate hebben delen van de wereld te maken met beperkende maatregelen en lockdowns die van invloed zijn op de economie. Wereldwijd heeft de coronacrisis ook voor de landbouw geleid tot een dubbele schok omdat zowel de vraag- als aanbodzijde getroffen worden (OECD, 2021a en 2021b). Maatregelen om de verspreiding van het virus onder controle te houden, hebben gevolgen gehad voor veel activiteiten in de mondiale toeleveringsketens, waaronder productie, verwerking, logistiek en detailhandel. Grens- en reisbeperkingen hebben vaak geleid tot tekorten aan

landbouwarbeiders, beperkte toegang tot inputs zoals zaden, meststoffen en pesticiden, lagere capaciteit in de voedselverwerkende industrie en uitdagingen bij de distributie van voedingsproducten.

Tegelijkertijd zorgden aanzienlijke inkomensdalingen, beperkingen in het verkeer van mensen en de sluiting van restaurants voor snelle veranderingen in de voedselconsumptiepatronen (FAO, 2021). Door de coronacrisis en ingestelde lockdown zaten mensen meer thuis, waardoor de foodsector (zoals supermarkten en speciaalzaken) veel meer verkocht (CBS, 2020a; 2021a; ING, 2021). In 2020 is de handel in landbouwgoederen minder geraakt door de coronapandemie dan de handel in niet-landbouwgoederen. Desalniettemin waren de internationale voedselmarkten, vooral in het tweede kwartaal van 2020, behoorlijk ontregeld, waar ook de Nederlandse import en export last van had (OECD, 2021a en 2021b;WUR, 2020). Als gevolg van het virus is de

\footnotetext{
7 Dit gebeurt door aftrek van de waarde van de geïmporteerde goederen en diensten die nodig
} waren om de landbouwexport te kunnen realiseren. De cijfers zijn berekend aan de hand van input- en outputtabellen van de Nationale Rekeningen van het CBS. De Nederlandse verdiensten wereldwijde voedselvoorziening verstoord en zijn veel prijzen naar boven geschoten.

De totale Nederlandse landbouwexport bereikte in 2020 met 95,7 miljard euro een nieuw record door prijsstijgingen, niet door volumegroei (Jukema et al., 2021). In 2021 is dit record opnieuw ruim verbroken (door zowel prijsstijging als volumegroei, zie paragraaf 2.2). De landbouwexport blijft ook belangrijk in het grote geheel. Als we kijken naar de verdiensten die Nederland overhoudt, dan zien we dat in 2020 zo'n 60\% van de totale landbouwverdiensten ${ }^{7}$ in Nederland aan de export te danken was ( $40 \%$ betreft verdiensten aan binnenlandse afzet). Dat is wel een lager percentage dan in de jaren ervoor, met name in vergelijking met 2019. In het coronajaar 2020 hebben de exportverdiensten het lastig gehad om door te groeien, terwijl de focus op lokale verkoop groter is geworden (Berkhout et al., 2021).

Dit hoofdstuk beschrijft hoe de handel in landbouwgoederen tijdens de coronacrisis verliep, waarbij de jaren 2019 (als pré-coronajaar) en 2020/2021 (als coronajaren) centraal staan. Paragraaf 7.2 gaat in op de gevolgen van de coronapandemie voor de Nederlandse handel in landbouwgoederen. In paragraaf $7.3 \mathrm{komt}$ de handel op EU- en niet-EU-niveau aan bod. In paragraaf 7.4 vindt een verdieping plaats door op het niveau van goederen te analyseren wat de gevolgen zijn van de pandemie op maandbasis. Paragraaf 7.5 ten slotte beschrijft de door de overheid gegeven coronasteun aan de agrosector in vergelijking met de bedrijven in de rest van de economie.

dankzij de afzet van landbouwgoederen door Nederlandse bedrijven bestaan uit de buitenlandse afzet (export) en de binnenlandse afzet. 


\subsection{Nederlandse goederenhandel en corona}

Nederlandse economie en internationale handel in crisis

In maart 2020 brak de coronacrisis in Nederland in alle hevigheid uit. Er werd een lockdown ingesteld die pas in de zomer stapsgewijs opgeheven werd. $\mathrm{Na}$ de grote terugval in het tweede kwartaal trad in de loop van 2020 herstel op bij de mondiale en Nederlandse goederenhandel. Mede door de versoepelingen in de zomer van 2020 en de herstelde productieketens was de internationale goederenhandel eind 2020 qua volume alweer op een hoger niveau dan vóór de coronacrisis (2019). Als gevolg van lage handelsprijzen (met name van minerale brandstoffen) was de handelswaarde eind 2020 nog wel lager dan in het vierde kwartaal van 2019. Hoewel de coronapandemie nog steeds voortduurt, is de Nederlandse goederenhandel inmiddels grotendeels hersteld van de enorme impasse die ruim een jaar geleden plaatsvond. De waarde van de Nederlandse goederenimport en -export ligt in de eerste drie kwartalen van 2021 boven het niveau van deze periode in pré-coronajaar 2019 (Creemers et al., 2021).

Handel in landbouwgoederen vertoont geen dip in 2020

De internationale goederenhandel werd niet voor alle goederen in dezelfde mate geraakt door de coronacrisis (figuur 7.1). De landbouwgoederen ${ }^{8}$ hadden relatief minder te lijden onder de coronacrisis en lijken daarmee minder conjunctuur- en crisisgevoelig. De noodzakelijkheid van voeding voor mensen maakt dat de coronatijd minder effect heeft gehad op de handel in landbouwgoederen dan op andere producten. Landbouwgoederen zijn essentiële goederen, waarbij het belang van het openhouden van de handelskanalen evident is. Daar staat tegenover dat, vanwege dezelfde mindere conjunctuurgevoeligheid, de handelsgroei in 2021 ook minder spectaculair was dan bij alle goederen samen. Vergeleken met het précoronajaar (2019) groeide de handel in landbouwgoederen in 2021 ongeveer even hard als de totale goederenhandel.

8 In dit hoofdstuk worden de landbouwgerelateerde goederen buiten beschouwing gelaten. Alle
cijfers hier gaan over de primaire en secundaire landbouw samen, behalve in figuur 7.4 waar ook de tertiaire landbouw bekeken wordt.

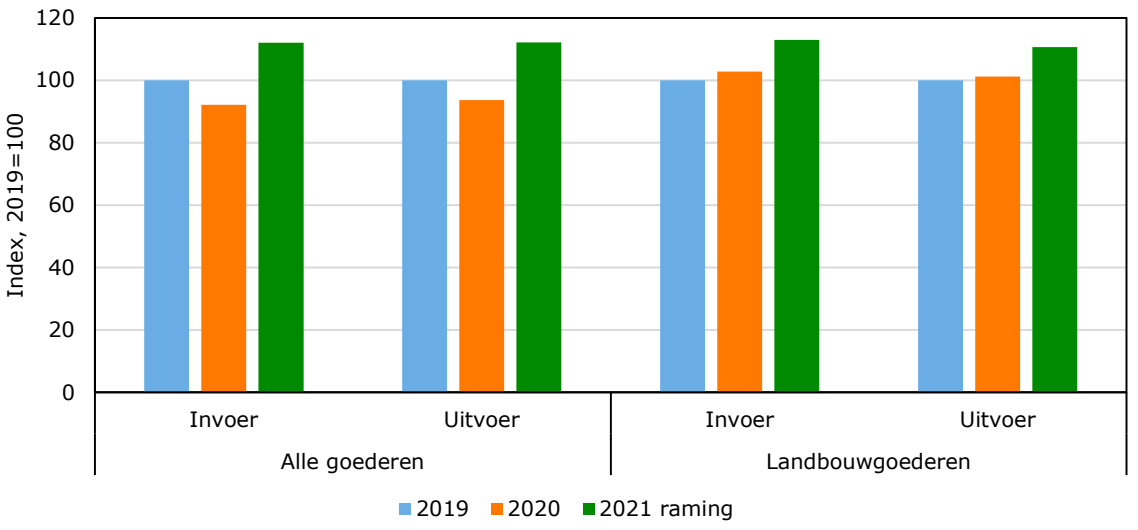

Figuur 7.1 Nederlandse goederenhandel (waarde), index 2019=100 Bron: CBS tot en met oktober 2021, raming november-december 2021 door CBS en Wageningen Economic Research.

\subsection{Handel met EU-landen versus niet-EU-landen}

De Nederlandse agrosector is sterk internationaal verweven. Door de maatregelen die genomen zijn tijdens de coronacrisis ondervonden en ondervinden diverse bedrijfsprocessen problemen. De coronapandemie had verschillende gevolgen voor de landbouwmarkten in de Europese Unie. Het grootste directe effect was zichtbaar aan de vraagzijde, aangezien de horeca van de ene op de andere dag werd gesloten. Producten die grotendeels voor die sector bestemd waren, konden vaak niet ergens anders worden gebruikt en in sommige gevallen, zoals snijbloemen, moest een groot deel van de productie worden vernietigd (Berkhout et al., 2020; New Zealand Embassy, 2020).

Niet alleen in Nederland werden diverse maatregelen getroffen, ook in andere landen van de EU werden lockdowns ingesteld om de verspreiding van het virus te voorkomen. De afgelopen twee jaar heeft de handel met EU-landen beter gepresteerd dan de handel met niet-EU-landen. ${ }^{9}$ Dat geldt zowel voor

Hier speelt overigens ook een effect dat niets te maken heeft met de coronapandemie, namelijk de ingang van de effectieve Brexit sinds 1 januari 2021 en de daardoor verminderde handel met het Verenigd Koninkrijk (zie verder hoofdstuk 6). 
landbouwgoederen als niet-landbouwgoederen (figuur 7.2 en 7.3). In 2021 was de export van landbouwgoederen naar EU-landen 14,0\% hoger dan in 2019, naar landen buiten de EU 5,7\%. Voor de import van landbouwgoederen zijn de ontwikkelingen EU versus niet-EU vergelijkbaar met die bij de export.

Binnen de EU kon via de zogenaamde Green Lanes ${ }^{10}$ veel handel blijven doorgaan en werd aldus de beschikbaarheid van voedsel voor de Europese burgers gegarandeerd (Europese Commissie, 2020). Een tweede reden betreft de goederenhandel via zeecontainers. ${ }^{11}$ De coronapandemie heeft door plotselinge lockdowns en logistieke verstoringen onevenredig hard de containerhandel met niet-EU-landen verstoord. De mismatch tussen een sterk stijgende vraag na het eerste herstel van de coronapandemie en de verminderde (te snel afgeschaalde) aanbodcapaciteit heeft geleid tot recordprijzen voor containervrachten op vrijwel alle handelsroutes (UNCTAD, 2021; Bakker, 2021; OECD, 2021b). Er zijn minder containers op de juiste plaatsen beschikbaar en havens hebben de capaciteit niet om te lossen en door te zetten naar vrachtwagens en treinen (UNCTAD, 2021; Bakker, 2021). Door de hogere transport- en grondstofprijzen zijn de kosten van afzet naar verre bestemmingen (nog veel) hoger dan deze vóór de coronacrisis waren (LogistiekProfs, 2021; Bakker, 2021; Van Heel, 2021). Rederijen kampen bijvoorbeeld met een groot tekort aan zeecontainers in China om aan de enorme vraag naar transportcapaciteit te voldoen. Hierdoor is de prijs van zeevracht vanuit Azië bijzonder gestegen (zie bijvoorbeeld UNCTAD, 2021; Multifix Group, 2021; Knopers, 2021).

Vooral aan koelcontainers is een tekort. Koelcontainers worden met name gebruikt voor het transport van voedsel, zoals vlees, fruit en groenten. Een tekort aan deze containers heeft gevolgen voor Nederlandse

(landbouw)bedrijven die voedsel (zoals uien, vlees, pootaardappelen, kaas, paprika) exporteren naar continenten die niet over land te bereiken zijn.

Daardoor is de export van deze producten duurder of vertraagd (zie bijvoorbeeld NT, 2020; Pluimveebedrijf, 2020; EVMI, 2020).

\footnotetext{
10 Door middel van de Green Lanes, geïntroduceerd door de Europese Commissie, moet het vrije verkeer van goederen in de interne markt van de EU zo soepel mogelijk blijven
} verlopen, nu de EU te maken krijgt met grenscontroles door het coronavirus. Green Lanes

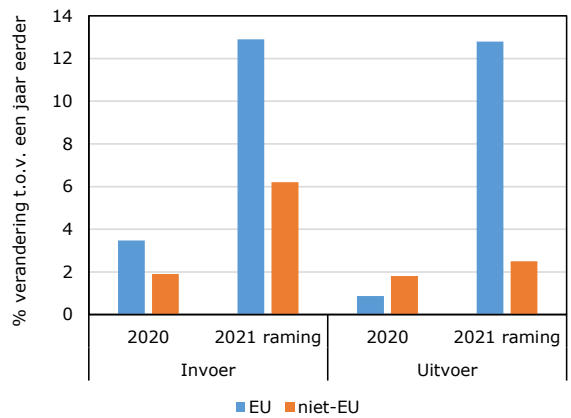

Figuur 7.2 Ontwikkeling handelswaarde landbouwgoederen

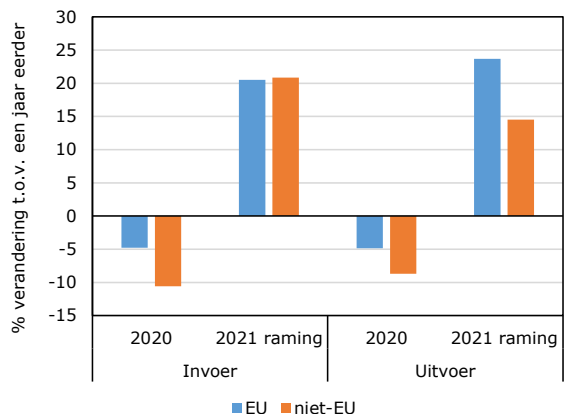

Figuur 7.3 Ontwikkeling handelswaarde alle goederen
Bron: CBS tot en met oktober 2021, raming november-december 2021 door CBS en Wageningen Economic Research.

Noot: het VK zit in de groep niet-EU voor alle getoonde jaren $(2019,2020$, 2021) om de vergelijking in de tijd robuust te maken.

\subsection{Goederensoorten tijdens de coronacrisis}

\section{Goederenexport op maandniveau}

Om te zien hoe de internationale handel voor de belangrijkste landbouwgoederen zich ontwikkelde tijdens de coronacrisis, bekijken we de goederenexport per maand. Figuur 7.4 toont de jaar-op-jaar exportontwikkeling van de primaire en secundaire landbouwgoederen, de tertiaire landbouwgoederen en de niet-landbouwgoederen per maand. De krimp die de goederenexport in april en mei 2020 doormaakte, blijft bij de primaire en secundaire landbouw heel beperkt. De exportwaarde van de nietlandbouwgoederen was in mei 2020 zo'n 28\% lager dan in mei 2019, terwijl de exportwaarde van het totaal van primaire en secundaire landbouwgoederen $10 \%$ lager lag. In de tweede helft van 2020 lag de waarde van de export van landbouwgoederen rond het pré-coronaniveau, de export van niet-

landbouwgoederen lag er nog onder. Pas in december 2020 ligt de export van

bestaan uit alle (nieuwe) grenscontroleposten die zijn en worden ingericht door lidstaten op het TEN-T netwerk (Europese Commissie, 2020).

${ }^{11}$ Het precieze effect op de handelswaarde is lastig te kwantificeren, omdat er zowel (waardeverhogende) prijseffecten als (waardeverlagende) volume-effecten spelen. 
niet-landbouwgoederen weer boven het niveau van een jaar eerder. De export van de tertiaire landbouwgoederen vertoont meer fluctuaties. Deze export lag in april en mei 2020 respectievelijk 6 en $9 \%$ lager dan in die maanden een jaar eerder, maar was in juni juist weer 12\% hoger dan in 2019.

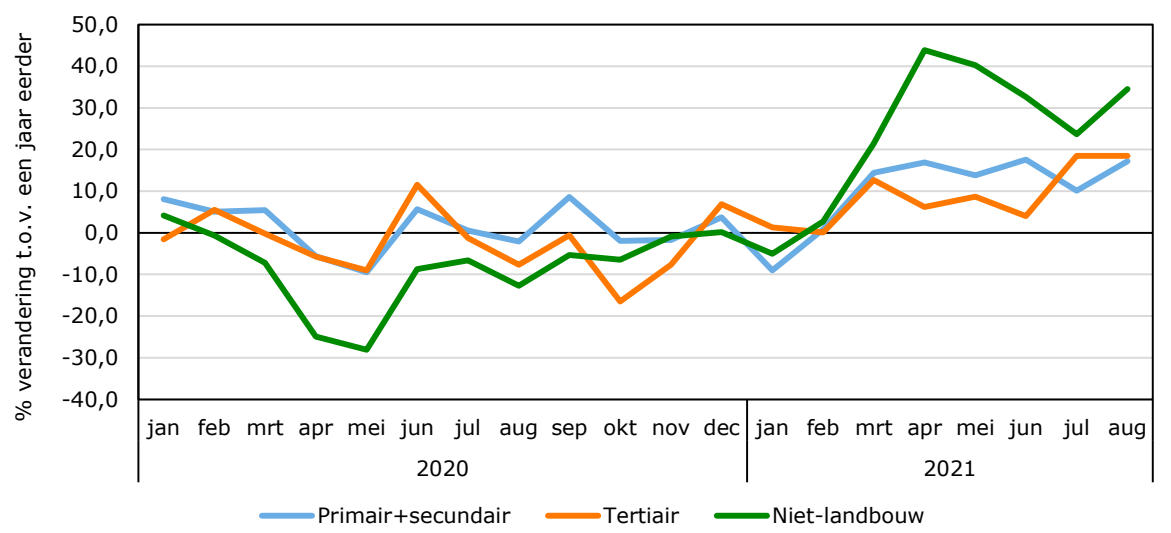

Figuur 7.4 Ontwikkeling van de exportwaarde per maand vergeleken met dezelfde maand een jaar eerder

Bron: CBS.

\section{Export fruit blijft op niveau}

De coronacrisis heeft schokken veroorzaakt in alle segmenten van de voedselvoorzieningsketens en heeft tegelijkertijd gevolgen voor de landbouwproductie, voedselverwerking, transport en logistiek en de finale vraag. Niet alle producten werden in gelijke mate getroffen en verschillende producten hebben te maken gehad met verstoringen in verschillende stadia van de toeleveringsketen (OECD, 2021b). De export van fruit is bijvoorbeeld goed overeind gebleven tijdens de coronapandemie, maar voor veel andere goederen was het coronajaar 2020 lastiger. Figuur 7.5 geeft de ontwikkeling van de exportwaarde van drie belangrijke ${ }^{12}$ landbouwproducten voor de export weer, met de jaar-op-jaar ontwikkeling per maand. De export van fruit had in 2020 geen exportverlies ten opzichte van 2019: iedere maand lag het niveau

${ }^{12}$ De top 5 belangrijkste landbouwgoederen qua exportwaarde bestaat uit sierteelt, vlees, zuive en eieren (niet getoond op de figuur), groenten (niet getoond op de figuur) en fruit. boven dat van 2019. De exportwaarde van fruit nam in de beginfase van de pandemie (april en mei 2020) nog toe, in tegenstelling tot bij andere belangrijke exportproducten. Uit een vergelijking tussen de exportwaarde en hoeveelheid blijkt dat dit vooral een prijseffect was: in die maanden nam de waarde wel toe ten opzichte van een jaar eerder - maar de hoeveelheid lag lager. In 2019 waren de prijzen van bijvoorbeeld appels en peren zeer laag (CBS, 2020b). In 2021 stond de export van fruit er echter minder goed voor alleen in maart, april en juni 2021 nam de exportwaarde (en -hoeveelheid) toe. In de andere maanden van 2021 (cijfers hier tot en met augustus) nam de waarde juist af vergeleken met een jaar eerder.

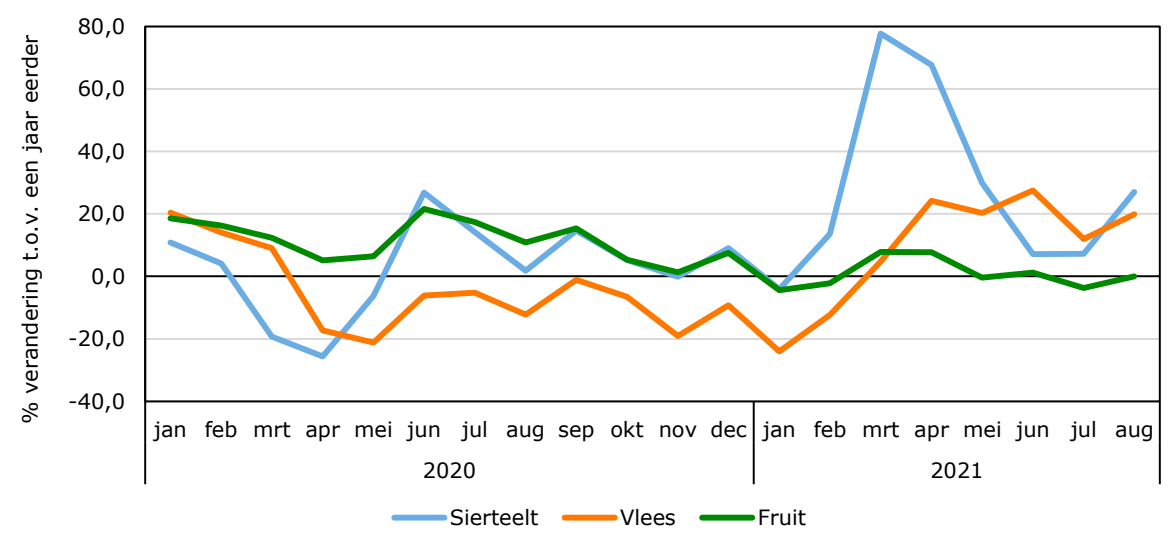

Figuur 7.5 Exportwaarde belangrijke landbouwgoederen voor de uitvoer, jaar-op-jaar ontwikkeling per maand Bron: CBS.

\section{Problemen sierteelt in begin 2020}

De krimp bij de sierteeltexport zette al vroeg in, met een afname van ruim $19 \%$ in maart 2020 en van bijna $26 \%$ in april (figuur 7.5). De sierteeltexport kwam in het eerste kwartaal van 2020 volledig stil te liggen door de mondiale lockdowns. Hierdoor kelderden de prijzen (CBS, 2020b). In juli, augustus en september 2020 nam de uitgevoerde waarde juist sterker toe dan de 
uitgevoerde hoeveelheid - waaruit blijkt dat de handelsprijzen juist weer toenamen. In de loop van 2020 stegen de prijzen weer fors doordat de vraag uit het buitenland weer toenam, terwijl Nederlandse telers hun productie juist hadden afgeschaald in verband met corona-onzekerheid (CBS, 2020b). Eind 2020 nam zowel de waarde als de hoeveelheid van de export van sierteelt toe, maar steeg de uitgevoerde hoeveelheid weer harder dan de uitgevoerde waarde. Dit duidt op een stabilisering van de handelsprijzen na de prijsstijging eerder. In maart en april 2021 groeiden zowel de hoeveelheid als de waarde van de export van sierteelt enorm. Dit komt mede omdat wordt vergeleken met de krimpmaanden van 2020 (CBS, 2021d en 2021e). Bij de sierteelt zien we dat de angst aan het begin van de pandemie groot was, maar dat de branche wat betreft export ook snel weer opkrabbelde.

\section{Handelsprijs voor vlees fluctueert}

In de maanden met de grootste teruggang in de handel door de coronapandemie (april en mei 2020) lag de waarde van vlees fors lager dan een jaar eerder, met als dieptepunt een krimp van ruim 21\% in mei 2020 ten opzichte van mei 2019 (figuur 7.5). Bij aanvang van de coronacrisis (april en mei 2020) was de procentuele krimp van de waarde groter dan de krimp van de hoeveelheid. Daaruit kunnen we opmaken dat de handelsprijzen harder afnamen dan het volume. Zo was in 2020 varkensvlees bijvoorbeeld $9 \%$ goedkoper dan een jaar eerder. De prijs stond ook onder druk door de uitbraak van de varkenspest in Duitsland (CBS, 2020b). Daarnaast valt op dat de waarde vanaf het tweede kwartaal van 2021 veel harder steeg dan het volume, duidend op een grote prijsstijging van geëxporteerd vlees. Ook in 2021 kampte de varkenssector met fors dalende prijzen (CBS, 2021d).

\footnotetext{
${ }^{13}$ Hier is het gebruik van de volgende steunmaatregelen meegenomen: tegemoetkoming loonkosten (NOW), tegemoetkoming vaste lasten (TOGS en TVL), tijdelijke

overbruggingsregeling voor zelfstandig ondernemers (Tozo), tegemoetkoming

fritesaardappeltelers en tegemoetkoming sierteeltsector (zie $\underline{\mathrm{CBS}}$ ). Het gaat om deelnames tot en met 31 augustus 2021 .
}

\subsection{Compensatie voor coronaverliezen door overheid}

Het Nederlandse bbp is in 2020 met 3,8\% gekrompen ten opzichte van précoronajaar 2019. Deze achteruitgang is net iets sterker dan de krimp in 2009 door de kredietcrisis en de sterkste krimp ooit door het CBS gemeten in vredestijd (CBS, 2021b, 2021c). De daling was in het tweede kwartaal het grootst met 9,9\% ten opzichte van het voorgaande kwartaal. En hoewel de consumptie van voedsel vaak niet conjunctuurgevoelig is, had de recessie uiteraard wel impact (OECD 2021a, 2021b). Ter ondersteuning van ondernemers tijdens de coronacrisis heeft de overheid financiële steunmaatregelen ingevoerd. Tot en met augustus 2021 ontvingen ruim 634.000 bedrijven steun uit één of meerdere van de coronasteunmaatregelingen, wat neerkomt op bijna een derde van alle Nederlandse bedrijven. ${ }^{13}$

\section{Relatief minder vaak coronasteun aangevraagd door agribusiness}

Bij de bedrijven in de agribusiness ${ }^{14}$ ligt de verhouding wat anders. Ruim 34.000 bedrijven in de agribusiness ontvingen coronasteun, wat neerkomt op bijna $29 \%$ van de bedrijven in die sector. Agribusiness-bedrijven maakten dus iets minder dan gemiddeld gebruik van steunpakketten gedurende de coronacrisis.

Van de agribusinessbedrijven die coronasteun ontvingen is $21 \%$ actief in de bedrijfstak supermarkten, voedingswinkels en markthandel. Agribusinessbedrijven in de groothandel, veeteelt en fokkerijen, teelt van eenjarige gewassen, dienstverlening voor de landbouw en vervaardiging van voedingsmiddelen maakten juist relatief veel gebruik van steunpakketten gedurende de coronacrisis (tabel 7.1).

\footnotetext{
${ }^{14}$ Tot de agribusiness behoort niet alleen de landbouwsector maar ook de voedingsmiddelenindustrie, groot- en detailhandel in levensmiddelen en ondersteunende dienstensectoren.
} 
Tabel 7.1 Agribusiness uitgesplitst naar bedrijfstak

\begin{tabular}{lrr} 
Type & $\begin{array}{r}\text { Aandeel met steun } \\
\text { in agribusiness }\end{array}$ & $\begin{array}{r}\text { Aandeel bedrijven } \\
\text { in agribusiness }\end{array}$ \\
\cline { 2 - 3 } & $\%$ & $\%$ \\
Supermarkten, voedingswinkels en markthandel & 21,0 & 13,7 \\
\hline Groothandel agribusiness & 20,5 & 13,5 \\
\hline Veeteelt en fokkerijen & 14,1 & 24,5 \\
\hline Teelt van eenjarige gewassen & 12,6 & 14,9 \\
\hline Dienstverlening voor de landbouw & 11,2 & 13,5 \\
\hline Vervaardiging van voedingsmiddelen & 7,4 & 5,4 \\
\hline Overig & 13,3 & 14,5 \\
\hline
\end{tabular}

Bron: CBS, RVO, Belastingdienst, UWV.

\section{Handelaren in landbouwgoederen kregen relatief iets vaker steun dan}

\section{alle Nederlandse handelaren}

Wanneer we enkel kijken naar de bedrijven die zich op de internationale markt begeven, ziet het beeld er anders uit. Van alle internationale handelaren (import en/of export van goederen) ontving meer dan $43 \%$ steun. Bij de internationale handelaren binnen de agribusinesssector is dat $45 \%$.

Een aantal sectoren binnen de internationaal actieve agribusiness springt eruit voor wat betreft de steunaanvraag. Zo vroeg bij de groothandel in landbouwgoederen $63 \%$ van de internationale handelaren steun aan; bij de supermarkten, voedingswinkels en markthandel was dat $60 \%$. Het aandeel was met $59 \%$ ook bovengemiddeld hoog voor de viskwekers. Voor zowel de vervaardiging van machines en chemicaliën voor de landbouw als de handelsbemiddeling geldt dat dit afgerond $100 \%$ is: vrijwel alle internationaal handelende bedrijven binnen deze bedrijfstakken ontvingen overheidssteun.

Bedrijfstakken waarvan de internationaal handelende bedrijven juist relatief weinig steun aanvroegen, zijn de dienstverlening voor de landbouw (27\%), de teelt van meerjarige gewassen (29\%), veeteelt en fokkerijen (26\%) en de visserij (30\%). 


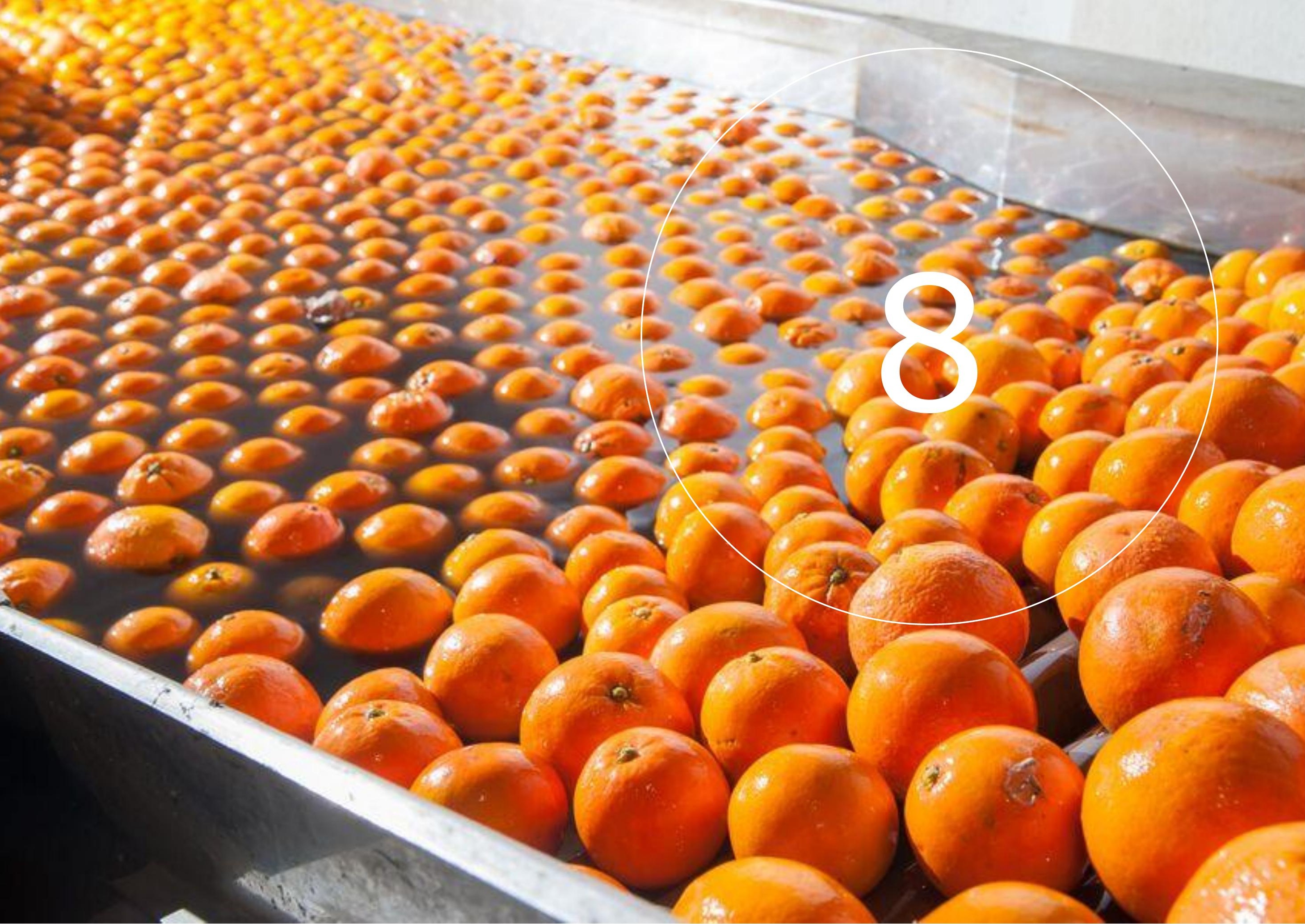




\section{Handelsbeleid voor de landbouw}

\subsection{Inleiding}

Kort na de Tweede Wereldoorlog brak de tijd aan voor een nieuwe economische wereldorde, met als pijlers de Wereldbank, het Internationale Monetaire Fonds (IMF) en de Algemene Overeenkomst over Tarieven en Handel (GATT). De oprichting van de GATT markeerde daarmee het begin van de internationale handelspolitiek. Sindsdien hebben er verschillende uitbreidingen aan deze overeenkomst plaatsgevonden wat in 1995 leidde tot de oprichting van de Wereldhandelsorganisatie (WTO). Daarbij zijn in totaal 164 landen aangesloten en gezamenlijk zijn die goed voor zo'n $96 \%$ van de wereldwijde handel.

Door bindende afspraken te maken over het verminderen van importtarieven, exportsubsidies en binnenlandse landbouwsteun stimuleert de WTO de mondiale marktintegratie. Mede door het afbouwen van importbelemmeringen en het harmoniseren van handelsregels is de internationale handel in landbouw- en voedselproducten de afgelopen 20-25 jaar enorm gegroeid (van bijna USD 500 miljard in 2001 naar ruim USD 1.600 miljard in 2019, (ITC, 2021)). De WTO-akkoorden streven geleidelijke steeds verdergaande liberalisering na, waarbij gelijkheid en wederkerigheid (non-discriminatie en reciprociteit) de twee belangrijkste principes zijn.

Ondanks de successen van de GATT bleef de landbouwsector lange tijd buiten schot omdat deze sector als een nationale aangelegenheid werd gezien. Pas met de afronding van de Uruguay-ronde in 1993 zijn verdergaande afspraken gemaakt over handelsliberalisering van de landbouw en afbouw van de mogelijkheden om steun te geven aan de sector. Dat leidde zelfs tot een aparte overeenkomst over landbouw (in het Engels Agreement on Agriculture, AoA).

${ }^{15}$ Het Sanitary and Phytosanitary Agreement (SPA) geeft wel enkele handvatten om maatregelen in te stellen ter bescherming van mens, dier en omgeving. De invalshoek is de gezondheid van mens, plant en dier (artikel 2).
Binnen dat verdrag werden tariefverlagingen van gemiddeld $24-36 \%$ voor ontwikkelende en ontwikkelde landen afgesproken. Desondanks blijft de landbouw ook na de Uruguay ronde nog altijd een bovengemiddeld beschermde sector.

Handelsverdragen, die in overeenstemming moeten zijn met de WTO-regels, zijn met name gericht op het benutten van comparatieve voordelen en stimuleren economische efficiëntie door mondiaal de toegang tot elkaars markten uit te breiden. De WTO-akkoorden ontberen concrete doelstellingen die bijdragen aan duurzame productie, behoud van biodiversiteit, gezonde voeding, dierenwelzijn of aan het beperken van klimaatverandering. ${ }^{15}$ De mogelijkheden om meer duurzame productiemethoden af te dwingen in WTO-verband ontbreken daardoor: er zijn bijvoorbeeld geen algemeen geldende duurzaamheidsstandaarden op basis waarvan invoer kan worden tegen gehouden als de handelspartner in gebreke blijft. De roep om in internationale handelsverdragen ook ruimte te geven aan beleid van de WTO-leden op het gebied van milieu, natuur, klimaat en dierenwelzijn, zonder dat dit beleid wordt ondergraven door claims op vrijhandel, wordt wel steeds luider (Berkhout en van Berkum, 2020). WTO-akkoorden geven wel de mogelijkheid om importen te reguleren als daar de gezondheid van mensen, dier en plant mee gediend is (het zogenaamde voorzorgsprincipe, vastgelegd in the Agreement on Agriculture, artikel XX(b); zie wto.org). Voorwaarde voor importbeperkende maatregelen is dan wel dat er wetenschappelijk bewijs is voor gezondheidsrisico's en dat de importbeperkende maatregelen niet discrimineren tussen landen of als verborgen handelsbeperkingen kunnen worden gezien. Deze maatregelen die de kwaliteit en veiligheid van producten ten goede kunnen komen maar tegelijkertijd de handel kunnen beïnvloeden noemen we niet-tarifaire maatregelen (NTM's). ${ }^{16}$

${ }^{16}$ We gebruiken hier bewust de term NTM en niet NTB (Niet-Tarifaire Barrière). Een maatregel hoeft namelijk niet per se handelsbelemmerend te zijn. Zo heeft onderzoek aangetoond dat met name SPS- en TBT-maatregelen de vraag naar en daarmee de handel in producten ook 
Dit hoofdstuk gaat in op verschillende vormen van handelsgerelateerde maatregelen in de landbouw. Dit gebeurt vanuit Nederlands perspectief, door te kijken naar de gemiddelde importtarieven (paragraaf 8.2) en de mate van NTM's waar Nederlandse exporteurs mee worden geconfronteerd

(paragraaf 8.3). Paragraaf 8.4 ten slotte gaat in op private initiatieven die kunnen bijdragen aan een verduurzaming van de landbouw.

\subsection{Importtarieven}

De mate waarin regeringen wereldwijd hun landbouw sector beschermen is lastig uit te drukken in één cijfer, onder andere omdat bescherming in vele verschillende vormen voorkomt. B5.1 in bijlage 5 geeft een overzicht van de voornaamste vormen van handelsbescherming.

Importtarieven kunnen in ad valorem of niet ad valorem termen worden uitgedrukt. De ad valorem importtarieven zijn daarbij het makkelijkst te kwantificeren, aangezien dit simpelweg een percentage van de verhandelde prijs behelst. Bijna de helft van de wereldwijde importtarieven op landbouwproducten komen echter in de vorm van niet-ad valorem termen (WTO, 2019). Denk hierbij aan een vast bedrag per transactie, of aan importquota. De cijfers die in de volgende paragraaf gebruikt worden zijn afkomstig van het International Trade Centre (ITC), die deze niet ad valorem tarieven omrekent tot een ad valorem equivalent, zodat er toch een gemiddelde is te rapporteren.

Toch zijn ook daar meerdere vormen van. Binnen de WTO gelden de regels van most favoured nation, dat wil zeggen dat alle leden van de WTO hetzelfde maximale handelstarief aan elkaar opleggen. Middels een mandaat van de lidstaten kan de Europese Commissie echter bilaterale handelsverdragen afsluiten met een individuele handelspartner. In dergelijke bilaterale akkoorden gunnen de partners elkaar veelal een voorkeursbehandeling in de zin van lagere dan de algemeen geldende WTO-importtarieven voor het onderlinge handelsverkeer. De gemiddelde cijfers die in de volgende paragraaf belicht worden houden rekening met dergelijke preferentiële tarieven waar Nederlandse exporteurs mee worden geconfronteerd in het buitenland.

kunnen verhogen doordat zij de kwaliteit van producten aanzienlijk kunnen verbeteren (Ghodsi, 2021; Franssen en Mounir, 2021).
Importtarieven op landbouw producten blijven hoog

Nederlandse exporteurs worden buiten de Europese Unie geconfronteerd met een gemiddeld gewogen importtarief van 7,5\%. Voor landbouwproducten (hier de eerste $24 \mathrm{GN}$-goederenhoofdstukken) ligt dat percentage flink hoger: gemiddeld $18 \%$ (tabel 8.1 ). Deze bovengemiddelde bescherming kan grotendeels verklaard worden doordat de landbouwsector nog altijd als een nationale aangelegenheid wordt beschouwd.

Binnen de Europese Unie worden geen importtarieven gerekend. Het gewogen gemiddelde externe tarief dat de EU oplegt aan geïmporteerde landbouwgoederen bedraagt echter zo'n 8,5\% (2,7\% voor alle goederen).

Volgens schattingen van de WTO (2019) zou de invoer van landbouwproducten in de EU zo'n 13-14\% hoger liggen in de afwezigheid van deze invoertarieven, wat neerkomt op zo'n 20 miljard euro hogere importwaarde.

Tabel 8.1 Gemiddelde importtarieven in top 10 Nederlandse exportbestemmingen van alle exportproducten en van landbouw producten (Hs01-24)

\begin{tabular}{lrrrr} 
Export bestemming & $\begin{array}{r}\text { Ongewogen } \\
\text { tarief }(\%)\end{array}$ & $\begin{array}{r}\text { Gewogen } \\
\text { tarief }(\%)\end{array}$ & $\begin{array}{r}\text { Ongewogen tarief, } \\
\text { landbouw (\%) }\end{array}$ & $\begin{array}{r}\text { Gewogen tarief, } \\
\text { landbouw (\%) }\end{array}$ \\
\hline China & 9,8 & 6,7 & 15,5 & 12,9 \\
\hline Verenigde Staten (VS) & 3,4 & 1,2 & 4,9 & 3,0 \\
\hline Zwitserland & 4,3 & 2,3 & 26,5 & 14,7 \\
\hline Rusland & 6,1 & 3,3 & 9,0 & 5,8 \\
\hline Japan & 4,2 & 4,5 & 17,8 & 27,1 \\
\hline Australië & 3,1 & 2,2 & 1,8 & 1,7 \\
\hline Turkije & 5,0 & 1,5 & 38,7 & 15,8 \\
\hline Saoedi-Arabië & 4,6 & 3,5 & 4,9 & 5,0 \\
\hline $\begin{array}{l}\text { Verenigde Arabische } \\
\text { Emiraten }\end{array}$ & 4,7 & 3,5 & 4,7 & 3,8 \\
\hline Canada & 1,8 & 1,5 & 14,2 & 14,0 \\
\hline $\begin{array}{l}\text { Gemiddelde van } \\
\text { alle niet-EU } \\
\text { bestemmingen }\end{array}$ & $\mathbf{1 1 , 1}$ & $\mathbf{7 , 5}$ & $\mathbf{2 5 , 3}$ & $\mathbf{1 8 , 0}$ \\
\hline
\end{tabular}

Bron: CBS en ITC MacMap. 
Noot: Cijfers zijn op basis van de effectief toegepaste tarieven aan Nederland. Effectief wil zeggen dat mogelijke preferentiële importtarieven op basis van een handelsverdrag hier in zijn verwerkt. Gewogen tarieven zijn op basis van handelswaardes.

\subsection{Sanitaire en fytosanitaire maatregelen}

De landbouw sector blijkt een bovengemiddeld beschermde sector uitgaand van de importtarieven. Naast importtarieven moeten importeurs en exporteurs ook rekening houden met kosten die voortkomen uit niet-tarifaire maatregelen. Er zijn vele verschillende NTM's, die door de Verenigde Naties worden ingedeeld in 16 aparte hoofdstukken (zie tabel B5.2 in bijlage 5). In dit katern kijken we alleen naar sanitaire en fytosanitaire (SPS) maatregelen, omdat deze zich specifiek richten op het beschermen van mens, dier en planten tegen ziektes, plagen of verontreinigende stoffen en daarom met name relevant zijn voor de landbouw.

\subsubsection{Aanwezigheid van sanitaire en fytosanitaire (SPS) maatregelen}

Om een eerste overzicht te krijgen van de mate waarin Nederlandse exporteurs te maken krijgen met SPS maatregelen geeft tabel 8.2 aan hoeveel procent van de Nederlandse export aan minimaal 1 SPS (opgelegd door het importerende land) moet voldoen. Met $26,4 \%$ voor alle geëxporteerde producten is dat nog relatief laag. Uit tabel 8.2 volgt ook dat dit percentage binnen de goederencategorieën 'Levende dieren en dierlijke producten' $(99,3 \%)$, 'plantaardige producten' $(93,3 \%)$, 'vetten en oliën' $(92,6 \%)$, en 'verwerkte voedselproducten, dranken en tabak' (92,2\%) fors hoger ligt. Verder komen deze SPS maatregelen vooral in de vorm van 'verboden of beperkingen van producten of stoffen (hoofdstuk A1)', 'tolerantiegrenzen voor residuen en beperkt gebruik van stoffen (hoofdstuk $A 2$ )' en conformiteitsbeoordelingen (hoofdstuk A8). Bij een conformiteitsbeoordeling moet een bedrijf kunnen aantonen dat het aan een bepaalde regel heeft voldaan. Omdat relatief veel maatregelen zo'n beoordeling vereisen komen deze conformiteitsbeoordelingen dus ook relatief veel voor (tabel 8.2).
Deze cijfers kunnen een indicatie geven van hoe omvangrijk SPS-maatregelen zijn, maar zeggen nog niets over de gevolgen ervan voor de internationale handel of de kwaliteit of veiligheid van de producten.

Tabel 8.2 Het aandeel van de totale Nederlandse export dat aan (onderdelen van) een SPS-maatregel onderhevig is (coverage ratio) naar goederencategorie en type SPS-maatregel, 2020

\begin{tabular}{lrrrrrrrrr} 
Goederencategorie (HS21) & A & A1 & A2 & A3 & A4 & A5 & A6 & A8 & A9 \\
Totaal & $\mathbf{2 6 , 4}$ & $\mathbf{1 9 , 5}$ & $\mathbf{1 9 , 1}$ & $\mathbf{1 6 , 3}$ & $\mathbf{1 6 , 4}$ & $\mathbf{0 , 4}$ & $\mathbf{1 5 , 4}$ & $\mathbf{2 1 , 2}$ & $\mathbf{0 , 9}$ \\
\hline $\begin{array}{l}\text { 1, Levende dieren } \\
\text { en dierlijke producten }\end{array}$ & 99,3 & 95,0 & 92,6 & 87,0 & 79,6 & 3,5 & 80,9 & 99,1 & 2,4 \\
\hline 2, Plantaardige producten & 93,3 & 88,7 & 54,2 & 57,1 & 54,6 & 2,8 & 53,7 & 92,2 & 2,9 \\
\hline 3, Vetten en oliën & 92,6 & 90,7 & 90,2 & 89,5 & 89,4 & 0,1 & 89,7 & 92,5 & 1,7 \\
\hline $\begin{array}{l}\text { 4, Verwerkte voedselproducten, } \\
\text { dranken en tabak }\end{array}$ & 92,2 & 83,0 & 77,3 & 80,9 & 73,6 & 0,8 & 73,1 & 86,2 & 6,4 \\
\hline 5, Minerale producten & 1,0 & 0,7 & 0,0 & 0,0 & 0,0 & 0,0 & 0,0 & 0,8 & 0,0 \\
\hline 9, Hout en houtproducten & 61,3 & 40,0 & 29,1 & 3,8 & 0,5 & 14,1 & 1,1 & 43,6 & 0,1 \\
\hline
\end{tabular}

Noot: De tabel toont alleen goederencategorieën waarbij tenminste $50 \%$ van de export onderhevig is aan SPS maatregelen.

A: (Alle) Sanitaire en fytosanitaire maatregelen (SPS); A1: Verboden of beperkingen van producten of stoffen vanwege SPS; A2: Tolerantiegrenzen voor residuen en beperkt gebruik van stoffen A3: Etiketterings-, markerings- en verpakkingsvereisten; A4: Hygiënische eisen; A5: Behandeling voor de eliminatie van plantaardig en dierlijk ongedierte en ziekteverwekkende organismen in het eindproduct (bijv. behandeling na de oogst); A6: Andere vereisten voor productie- of postproductieprocessen; A8: Conformiteitsbeoordeling met betrekking tot SPS; A9: SPS maatregelen n.e.g.

A7 bestaat niet (UNCTAD, 2019b)

Het gros van de NTM's komt tot stand op basis van het voorzorgsprincipe in artikel XX van het Agreement on Agriculture (Hoekman en Nicita, 2018). Toch blijkt het in de praktijk niet altijd even eenvoudig hier een beroep op te doen. Zo heeft de EU op grond van dit voorzorgsprincipe diverse malen importen geweerd vanwege verwachte negatieve effecten op de veiligheid en gezondheid van mens, dier en plant. Veel andere landen vochten dat aan bij de WTO, uitgaand van het principe dat handelsbeperkende maatregelen niet zijn toegestaan zolang negatieve effecten zich niet hebben voorgedaan. Talrijke zaken zijn onderwerp geweest van WTO Dispute Settlement procedures. Een bekend voorbeeld is de 
boycot die de EU in 1989 op de invoer van rundvlees van met groeihormonen behandelde runderen instelde, omdat volgens de EU de consumptie van dergelijk vlees schadelijk zou zijn voor de consument. De WTO oordeelde echter dat er niet voldoende wetenschappelijk bewijs voor gezondheidsrisico's was om een EUboycot te rechtvaardigen (Gooren en Huige, 2013).

\subsubsection{Handelskosten van SPS maatregelen}

Een coverage ratio meet de absolute aanwezigheid van NTM's in de handel. Het zegt echter niets over de zwaarte van een maatregel, noch wat de gevolgen kunnen zijn voor de kwaliteit van de producten, tot hoeveel kosten het kan leiden of in hoeverre het de internationale handel kan beïnvloeden. Met name dat laatste is vanuit beleidsperspectief erg interessant. Wanneer namelijk aangetoond kan worden of een bepaalde maatregel meer kosten dan baten met zich meebrengt, is hij mogelijk niet in lijn met de voorwaarden van het voorzorgsprincipe. Daarom zijn er vanuit de academische literatuur verschillende manieren om dergelijke gevolgen van NTM's toch economisch te kwantificeren.

Zo gebruiken Ghodsi et al.(2016) een model waarmee in een eerste stap het effect van NTM's op de internationale handel kan worden berekend. Een dergelijke analyse maakt inzichtelijk welke NTM's in welke landen op welke producten een statistisch significant negatief effect op de handel hebben, en welke niet. Daarmee kan dus het onderscheid gemaakt worden tussen een handelsbelemmerende en een niet-handelsbelemmerende maatregel. In een tweede stap wordt dat effect op handelswaarden omgezet naar een effect op prijzen door gebruik te maken van importelasticiteiten (de verandering in importhoeveelheid als gevolg van een verandering van de importprijs). Wanneer vervolgens geobserveerd wordt dat de prijs $x$ procent hoger ligt in de aanwezigheid van een NTM, wordt aangenomen dat deze hogere prijs de kosten van de NTM vertegenwoordigt in ad valorem equivalente (AVE) termen. Het is ook mogelijk dat de prijs juist lager ligt. In dat geval had de maatregel een handelsfaciliterend effect. Dit kan bijvoorbeeld komen doordat een maatregel de kwaliteit van het product aanzienlijk verbetert en daarmee de vraag naar een product significant vergroot (Ghodsi, 2021).

Op basis van de data van Ghodsi et al. (2016) blijkt dat SPS-maatregelen wereldwijd de prijs van landbouwproducten met zo'n $0,5 \%$ verhogen. Ervan uitgaande dat deze prijs de additionele kosten vertegenwoordigt van de maatregelen, is de ad valorem kostenequivalent van deze regels dus $0,5 \%$. Wanneer er alleen gekeken wordt naar SPS-regels die een significant negatief effect op de handel hadden dan is de wereldwijde AVE, met een percentage van $32,7 \%$, fors hoger. Voor de Nederlandse export van landbouwgoederen buiten de EU in 2020 lag de prijs juist gemiddeld 1,9\% lager. Wanneer we wederom alleen naar handelsbelemmerende SPS-regels kijken dan lag de prijs juist weer $20,6 \%$ hoger.

Hoe kan het grote verschil tussen alle maatregelen en alleen handelsbeperkende maatregelen verklaard worden? Ten eerste blijkt dat niet alle SPS-maatregelen handelsbelemmerend zijn. Zo betekent de negatieve AVE van $1,9 \%$ dat SPS maatregelen in het buitenland over het algemeen handelsfaciliterend van aard zijn. Eerder onderzoek heeft ook al aangetoond dat met name maatregelen in categorie A1- (verboden of restricties omwille van SPS-regels) en A5- (behandeling voor eliminatie van plant- en dierziektes) in het buitenland de kwaliteit van uit Nederland geëxporteerde landbouw producten aanzienlijk kunnen verhogen (Franssen en Mounir, 2021). Aangezien de kwaliteit van de Nederlandse export tot de top van de wereld behoort kunnen dergelijke maatregelen Nederlandse exporteurs ook een comparatief voordeel geven. Toch blijft het ook mogelijk dat sommige maatregelen meer kwaad dan goed doen. Het is daarom onmogelijk om generieke uitspraken te doen over het effect en daarmee de validiteit van NTM's, dit is hoe dan ook een kwestie die per maatregel en per land apart gewogen dient te worden.

\subsubsection{Bilaterale handelsverdragen}

Bilaterale handelsverdragen kunnen de handelskosten van zowel importtarieven als NTM's verlagen. Zo kunnen afspraken gemaakt worden over preferentiële importtarieven of de harmonisering van regels, of kan bijvoorbeeld een clausule worden opgenomen over wederzijdse conformiteitsbeoordelingen. In dat laatste geval hoeft een bedrijf maar in één land aan te tonen dat het aan een bepaalde regel heeft voldaan en neemt de handelspartner die beoordeling over. Binnen bilaterale akkoorden kunnen ook afspraken gemaakt worden over hogere (dan WTO-) eisen aan elkaars producten op het terrein van voedselveiligheid, milieuvoorwaarden, gezondheidsaspecten, arbeidsstandaarden en dierenwelzijn. 
$\mathrm{Nu}$ is het al zo dat producten uit derde landen dienen te voldoen aan de Europese standaarden op gebied van voedsel- en productveiligheid en etikettering. Soms wordt afgesproken dat derde landen de EU SPS-regelgeving implementeren. Daarbij kan de EU ook ruimte geven aan de handelspartner om gedurende een afgesproken overgangstermijn ervoor te zorgen dat producten die vanuit het partnerland naar de EU worden geëxporteerd, ook daadwerkelijk voldoen aan de Europese eisen. Dit is bijvoorbeeld onderdeel van het EU-Oekraïne Associatieakkoord. In dit akkoord wordt Oekraïne met financiële steun en experts van de EU in de gelegenheid gesteld om het veterinaire, fytosanitaire en voedselkwaliteitssysteem te verbeteren, met als inzet dat de import van (onder meer) kippenvlees en eieren uit Oekraïne aan de Europese SPS- en dierenwelzijnseisen dient te kunnen voldoen. Vanaf 2018 voegt Oekraïne stapsgewijs deze Europese regelgeving in de nationale regelgeving in. De EU kan die eisen stellen omdat het een grote koopkrachtige en dus interessante markt is. De EU blijkt in toenemende mate in staat te zijn haar hoge standaarden tot norm te stellen voor andere landen - dit is bekend als het 'Brussels-effect' (zie NRC-interview met Anu Bradford, 6 maart 2020). Een voorbeeld hiervan zijn de normen voor dierenwelzijn.

Bij het ontbreken van WTO-afspraken op dit terrein, neemt de EU in recent afgesloten bilaterale handelsverdragen de aanbevelingen van de Wereld Organisatie van Diergezondheid (OIE) inzake dierenwelzijnsnormen als referentiedoelen; deze dient de handelspartner - vaak na een korte overgangstermijn - ook te implementeren. Die OIE-richtlijnen zijn niet geheel hetzelfde als de EU-dierenwelzijnseisen, maar zijn wel sterk door EU-beleid en -wetgeving op dit terrein beïnvloed (Broom, 2017).

Als de EU serieus werk wil maken van duurzamere landbouw en daarvoor richtlijnen voor 'sustainable agricultural practices' opzet, zou het mogelijk moeten zijn om met een verwijzing naar de aantrekkelijkheid van haar markt, deze normen af te dwingen bij haar handelspartners door ze onderdeel te maken van bilaterale handelsafspraken.

\subsection{Private initiatieven}

Niet alleen de overheid kan een rol spelen in het verduurzamen van handel, ook private partijen nemen initiatieven. Een vraag die daarbij speelt, is wie doet wat? Anders geformuleerd, wat behoort tot het publieke domein en wat tot het private domein? Het antwoord daarop is afhankelijk van welk aspect van verduurzaming van belang is. Gaat het om een aspect dat niet verdisconteerd kan worden in de (kost)prijs, zoals het geval is bij publieke goederen als landschap of biodiversiteit. Of gaat het om aspecten waarbij dat wel mogelijk is, zoals dierenwelzijn, kinderarbeid of milieu? In het laatste geval zijn in eerste instantie bedrijven aan zet. Een probleem daarbij is echter de vrijblijvendheid en daarmee de ondergraving door bedrijven die niet deelnemen (vrijbuitersprobleem), met name als het niet voor alle afnemers (consumenten) vanzelfsprekend is om voor aspecten als dierenwelzijn of hogere milieueisen te willen betalen. Waarom zou je dan als bedrijf verder gaan dan de wettelijke vereisten? Welke prikkel bestaat daarvoor? En wat doe je in geval er helemaal geen normen zijn vastgelegd? Dit probleem speelt zowel nationaal als internationaal.

Een bedrijf kan daar verschillend mee om gaan. Een optie is om het in acht nemen van hoge(re) standaarden als een vorm van marketing te zien, een mogelijkheid om je als bedrijf te onderscheiden en zo bepaalde consumentensegmenten te bereiken. Het kan ook zijn ingegeven door morele overwegingen, omdat je als bedrijf niets te maken wilt hebben met kinderarbeid. Ook dat kan een positief effect hebben op de marktpositie. Of een bedrijf zijn hogere standaarden kan vermarkten, hangt onder meer af van de positie van het bedrijf in de keten en in de markt. Samenwerking met andere ketenschakels of andere bedrijven kan een goede strategie zijn om het positieve effect te vergroten, hoe meer bedrijven meedoen hoe groter de invloed. Succesvolle initiatieven als de Ronde Tafels voor Duurzame Soja (RTRS) en voor palmolie (RSPO) laten zien dat bedrijven de handen in een slaan en de gevolgen van handel voor natuur, milieu en klimaat serieus nemen.

Deze initiatieven blijven echter beperkt tot de deelnemende partijen en zijn dus niet generiek van toepassing. Daarmee ligt ondermijning van nietdeelnemende bedrijven op de loer. Denk bijvoorbeeld aan de invoer in Nederland van eieren die zijn geproduceerd onder andere (lagere) eisen dan de nationale, of aan invoer van producten waarin palmolie of soja is verwerkt die niet voldoen aan de eisen van de Ronde Tafels. Grote internationaal opererende ketens in de voedselindustrie zouden een belangrijke stimulerende rol kunnen spelen door meer duurzaamheidseisen aan inkoop te verbinden. 
Om het vrijbuitersprobleem echt aan te pakken, is uiteindelijk de enige optie om van overheidswege minimumeisen vast te leggen. Het zijn immers veelal productattributen die (vooralsnog) een deel van de consumenten aanspreken. Het gemeengoed maken van deze eisen, vereist uiteindelijk borging in wet- en regelgeving van de overheid. Daarmee doemt een tweede probleem op. Als land A de standaarden wel vastlegt en land B niet, dan is er alsnog het risico op ondermijning. Dit betekent dat ook internationaal deze borging nodig is. Voor Nederland loopt dat vooral via de EU.

Terecht noemt de EU-landbouwstrategie Van-boer-tot-bord ook de noodzaak om internationaal 'de boer op te gaan' met het bevorderen van de 'transitie naar een duurzamer voedselsysteem' (EC, 2020:20). Zoals hiervoor

aangegeven, is er binnen het kader van de WTO weinig ruimte om rekening te houden met natuur, milieu- en klimaatdoelstellingen. Veel leden van de WTO zijn hierin terughoudend vanwege de vrees dat zo een ongelijk speelveld tussen de landen kan ontstaan als gevolg van uiteenlopende ideeën over het gewenste niveau van duurzaamheid of dierenwelzijn. Maar deze opstelling maakt het wel heel lastig om de internationale doelstellingen over duurzame ontwikkeling en klimaatverandering (onder andere Sustainable Development Goals, Parijs Klimaatakkoord, Conventie voor Biologische Biodiversiteit) te realiseren.

Het is dan ook noodzakelijk dat er meer internationale aandacht komt voor de afstemming van handelsbelangen met de mondiaal vastgelegde duurzaamheids-, milieu- en klimaatdoelstellingen, bij voorkeur binnen WTOkader. Voor die afstemming schieten particuliere initiatieven tekort. Er is veel meer internationale coördinatie nodig, waarbij op basis van wetenschappelijke inzichten en 'best practices' gewerkt wordt aan coherent handels-, milieu- en klimaatbeleid.

\section{Due diligence steeds meer van belang}

Naast de kaders die de WTO stelt aan handel, zijn er zogenaamde UN Guiding Principles on Business and Human Rights (UN, 2011). Deze richtlijnen van de VN stammen uit 2011 en zijn unaniem door de VN-lidstaten goedgekeurd. Het doel is het voorkomen en aanpakken van het risico van negatieve gevolgen voor de mensenrechten als gevolg van bedrijfsactiviteiten.
In 2018 presenteerde de OESO een handreiking voor due diligence (gepaste zorgvuldigheid). De kern van due diligence is dat een bedrijf negatieve gevolgen van de bedrijfsactiviteiten op sociaal en milieugebied voorkomt dan wel aanpakt. De handreiking volgt uit de verklaring van de G7-leiders uit juni 2015, waarin zij het belang van een gemeenschappelijk referentiekader voor due diligence onderkennen en bedrijven aanmoedigen om due diligence te implementeren in hun toeleveringsketens. In juli 2017 committeerden G20 leiders zich met een verklaring aan de implementatie van normen op het gebied van arbeid, maatschappij, milieu en mensenrechten in overeenstemming met internationaal erkende kaders, met als doel duurzame en inclusieve toeleveringsketens te realiseren. De G20 onderstreepte daarbij de verantwoordelijkheid van ondernemingen voor de toepassing van due diligence (OESO, 2018).

Naar verwachting publiceert de Europese Commissie in maart 2022 een richtlijn op het gebied van Sustainable corporate governance. Op basis van deze richtlijn zouden bedrijven in de EU verplicht worden om due diligence toe te passen in hun toeleveringsketens, het gaat dan zowel om sociale thema's (zoals kinderarbeid, slechte werkomstandigheden, slavernij) als milieu-thema's (zoals klimaat, biodiversiteit). Dit past bij de hiervoor genoemde

beleidsvoornemens van de EU zoals uiteengezet in de Green Deal en Van-boertot-bord. In november 2021 is al wel een voorstel van de EC gepubliceerd voor een verordening die tot doel heeft het verbruik van producten die kunnen worden geassocieerd met ontbossing en bosdegradatie te minimaliseren, en de vraag in de EU naar en de handel in legale en 'ontbossingsvrije' grondstoffen en producten te doen toenemen. (zie ook paragraaf 11.2) (Europese Commissie, 2021a).

In juni 2021 is al wel een EU Gedragscode voor een verantwoordelijke handelsen bedrijfspraktijk in de voedingssector gepubliceerd (EU, 2021). Deze op vrijwilligheid gebaseerde gedragscode bevat gemeenschappelijk na te streven ambities en indicatieve acties voor 'actoren tussen de boerderij en het bord'. Ambitie nummer 7 is duurzame bevoorrading in voedselvoorzieningsketens en stelt de volgende streefdoelen vast:

1. Toeleveringsketens die niet bijdragen aan ontbossing, aantasting van bossen en vernietiging van natuurlijke habitats en die hoogwaardige ecosystemen en biodiversiteit in stand houden en beschermen.

2. Betere sociale prestaties in (mondiale) voedselvoorzieningsketens. 
Het Nederlandse beleid voor Internationaal Maatschappelijk Verantwoord Ondernemen (IMVO) is vooralsnog vooral gebaseerd op vrijwilligheid, en concreet uitgewerkt in convenanten tussen bedrijfsleven, overheid en

maatschappelijke organisaties (zie www.imvo.nl), maar volgens een evaluatie onvoldoende effectief (BuZa, 2020). Nederland zet daarom nu in op een brede due diligence verplichting, die bij voorkeur op EU-niveau tot stand komt. 


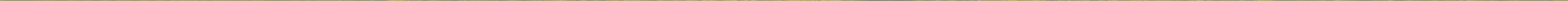




\section{$9.1 \quad$ Inleiding}

Nederland is niet alleen een van de grootste landbouwexporteurs in de wereld, maar ook een van de grotere landbouwimporteurs. Op basis van landgebruikcijfers is duidelijk dat Nederland ook sterk importgeoriënteerd is. Zo is er veel grond nodig voor het produceren van voedsel, hout en papier voor Nederlands gebruik. Het grondgebruik voor alleen de Nederlandse voedselconsumptie is anderhalf maal het totale beschikbare agrarische areaal in Nederland ${ }^{17}$ (Van Oorschot et al., 2021; CLO, 2020). Dit hoofdstuk laat zien dat er, zowel direct als indirect, ook heel veel wordt ingevoerd voor de export. Op basis van de nieuwste data-inzichten wat betreft de Nederlandse landbouwimport wordt uitgelegd in hoeverre en op welke wijze de Nederlandse landbouwexport afhankelijk is van landbouwimport. ${ }^{18}$ Daarnaast is in kaart gebracht welk deel van de Nederlandse landbouwimport voor de Nederlandse markt bestemd is.

\subsection{Ontwikkeling landbouwimport naar bestemming}

Tabel 9.1 toont de ontwikkeling van de Nederlandse landbouwimport (in euro) voor wat betreft bestemming voor de periode 2015-2020. Import voor wederuitvoer heeft het grootste aandeel, het gaat om invoer van goederen van buitenlandse makelij die na aankomst in Nederland niet of nauwelijks een

${ }^{17}$ Indien hout en papier worden meegeteld dan zit het buitenlandse landgebruik voor de Nederlandse consumptie nog een stuk hoger. Voor de totale Nederlandse consumptie (alle goederen, ook niet-landbouw) geldt dat maar liefst $80 \%$ van het land dat daarvoor nodig is, in het buitenland ligt ( $20 \%$ in Nederland). Hout- en papierconsumptie vragen het meeste landgebruik (46\%), gevolgd door vlees en zuivel (18\%) en overige landbouw (14\%). Zie verder Van Oorschot et al. (2021), CLO (2020) en Agrio (2020).

${ }^{18}$ In hoofdstuk 3 van de Internationaliseringsmonitor 'Handel en milieu' (CBS, 2021a) is er ruim aandacht voor de verwevenheid tussen landbouwimport en -export. Zo wordt getoond dat bewerking ondergaan en daarna weer worden doorgevoerd naar het buitenland. Daarnaast komt nog eens $27 \%$ indirect, na verwerking in Nederland in het buitenland terecht. Dat betekent dat 30\% van de Nederlandse importwaarde aan landbouwgoederen in Nederland blijft. Van die $30 \%$ is 17 procentpunt direct bestemd voor Nederlandse consumptie en 13 procentpunt bestemd voor consumptie $^{19}$ na bewerking of verwerking in Nederland. De vergelijking door de tijd laat zien dat de verdeling heel stabiel is.

Tabel 9.1 Waarde landbouwimport ${ }^{\text {a) }}$ naar bestemming

\begin{tabular}{rrrrrr} 
& $\begin{array}{r}\text { Invoer } \\
\text { totaal } \\
\text { (miljard } \\
\text { euro) }\end{array}$ & $\begin{array}{r}\text { Invoer voor } \\
\text { wederuitvoer } \\
(\%)\end{array}$ & $\begin{array}{r}\text { Invoer voor } \\
\text { directe } \\
\text { consumptie in } \\
\text { Nederland } \\
(\%)\end{array}$ & $\begin{array}{r}\text { Invoer voor } \\
\text { consumptie in } \\
\text { Nederland na } \\
\text { verwerking in } \\
\text { Nederland } \\
(\%)\end{array}$ & $\begin{array}{r}\text { Invoer voor } \\
\text { export na } \\
\text { verwerking in } \\
\text { Nederland } \\
(\%)\end{array}$ \\
\hline 2015 & 54,9 & 42 & 17 & 14 & 26 \\
\hline 2016 & 58,0 & 42 & 17 & 14 & 27 \\
\hline 2017 & 62,4 & 43 & 16 & 13 & 27 \\
\hline 2018 & 63,6 & 42 & 17 & 14 & 27 \\
\hline 2019 & 65,9 & 43 & 17 & 14 & 27 \\
\hline
\end{tabular}

a) Het gaat hier om de som van primaire en secundaire landbouwgoederen. Het betreft waardecijfers van de

nationale rekeningen van het CBS, waardoor de randtotalen hier iets afwijken van de cijfers in eerdere hoofdstukken. Bron: CBS

maar liefst $84 \%$ van de door Nederland ingevoerde palmolie uiteindelijk in het buitenland terechtkomt (het grootste deel na verwerking in Nederland) en dat de Nederlandse vleesexport (indirect) afhankelijk is van een breed palet aan ingevoerde goederen, met name levende dieren, veevoer-ingrediënten en nog te bewerken vlees.

${ }^{19}$ Met consumptie wordt hier bedoeld consumptie in brede zin oftewel finale vraag. Dat betreft niet alleen consumptie door particuliere huishoudens, maar ook consumptie door bedrijven of overheden. 
Bij niet-landbouwgoederen (zoals ingevoerde computers of aardolie) is een vergelijkbaar percentage van de import uiteindelijk bestemd voor het buitenland: $71 \%$ in 2020 . Er is wel significant meer invoer voor wederuitvoer, dus minder Nederlandse verwerking voor de export. In het buitenlandaandeel (72,2\% in 2015$)$ is er bij de niet-landbouw een lichte daling zichtbaar. Ook het percentage van de import dat direct wordt afgezet in Nederland is vergelijkbaar met het percentage bij de basislandbouw: $17 \%$.

Op basis van deze cijfers is de conclusie dat een groot deel van de Nederlandse landbouwimport direct of indirect bestemd is voor de export, maar dat dit ook geldt voor andere goederen. De landbouwimport past daarmee in het algemene plaatje van Nederland Handelsland (Bohn et al., 2021).

\subsection{Specifieke landbouwgoederen}

Tabel 9.2 toont de landbouwimport vanuit een productperspectief met voor elke importstroom een top vijf van relatief meest voorkomende

landbouwgoederen. Om minder belangrijke importstromen niet mee te nemen, is gekozen voor een ondergrens van een half miljard euro per importstroom in 2020. Daarbij vallen wel enkele interessante resultaten net weg uit de tabel, zoals tabaksproducten die nog het meest direct voor de Nederlandse consumptie zijn bestemd ( $48 \%$ ) of koffie en thee waarvoor hetzelfde geldt.

Landbouwgoederen waarbij de import het vaakst direct bestemd is voor het buitenland zijn fruit (72\%) en sierteelt (69\%). Bij fruit gaat het om 5,3 miljard euro in 2020. De avocado is bijvoorbeeld een typische fruitsoort die voor het overgrote deel wordt wederuitgevoerd. Nederland heeft zich de afgelopen tien jaar ontwikkeld tot de grootste mondiale avocadohub en is de tweede avocadoimporteur ter wereld na de Verenigde Staten (VS). De import en export van avocado's is een logistieke specialisatie van Nederland geworden en behelst naast transport en distributie ook zaken als rijping, controle en eventuele verpakking. Slechts $9 \%$ van de ingevoerde avocado's is bestemd voor de Nederlandse markt (CBS, 2020). Bij de sierteelt zijn rozen uit met name Ethiopië en Kenia typische bloemen die veel via bloemenveilingen in Nederland in het buitenland terecht komen (Nieuwe Oogst, 2020). Graan en meel worden juist heel weinig direct na invoer naar het buitenland vervoerd.
Landbouwgoederen die na import het meest direct in Nederland worden geconsumeerd zijn vaak eindproducten, waarbij verdere bewerking voor consumptie niet meer nodig is. Naast de genoemde producten tabak, koffie en thee gaat het bijvoorbeeld om diverse voedselbereidingen, zuivel en eieren, en specifieke vleessoorten (denk aan Argentijns of Japans rundvlees).

In vergelijking met andere landbouwproducten wordt ook nog relatief veel vlees in Nederland geconsumeerd na verdere bewerking in Nederland. Graan wordt echter het meest bewerkt in Nederland voor consumptie in Nederland (diverse brood- en bakkerijproducten). Hetzelfde geldt voor natuurlijke vetten en oliën (zoals palmolie).

Tenslotte is er de categorie 'import voor export na verwerking in Nederland'. Graan $(64 \%)$, levende dieren (53\%), cacao en bereidingen $(52 \%)$, natuurlijke vetten en oliën (43\%) en oliehoudende zaden en vruchten (41\%) zijn landbouwgoederen die het meest in Nederland worden verwerkt na import voor de export. Zo zijn mais, tarwe, palmolie en sojabonen veevoer-ingrediënten die via Nederland direct als veevoer of indirect als vlees of melk in het buitenland terecht kunnen komen (CBS, 2021a). Sojameel uit sojabonen wordt gebruikt als veevoergrondstof en sojaolie uit sojabonen wordt vooral gebruikt in producten voor menselijke consumptie. Een sojaboon bestaat uit circa $80 \%$ sojameel en $20 \%$ sojaolie (Nevedi, 2019).

Palmolie is naast een veevoerbestanddeel ook een ingrediënt van vele voedingsmiddelen (zoals soep, babyvoeding, chips, margarine, pindakaas), maar het zit ook in bijvoorbeeld shampoo, cosmetica, huisdierenvoer of biobrandstoffen (CBS, 2021a). Ingevoerde cacaobonen worden grootschalig verwerkt tot chocolade of halffabricaten zoals cacaopoeder en cacaoboter, bijvoorbeeld om er chocolade van te maken in België of Duitsland. Nederland is de grootste importeur van cacaobonen in de wereld, de nummer drie met palmolie en de vierde importeur van sojabonen (CBS, 2019). Tenslotte heeft Nederland zich gespecialiseerd in het fokken en opgroeien van kalveren voor de export. Een belangrijk deel van de Nederlandse export van rundvlees betreft kalfsvlees, waarbij meer dan de helft van de Nederlandse vleeskalveren uit het buitenland komt. Nederland telt circa 1 miljoen vleeskalveren (CBS, 2021b). 
Tabel 9.2 Landbouwimport naar bestemming en product (ondergrens van 0,5 miljard per importstroom), 2020

\begin{tabular}{|c|c|c|}
\hline Top 5 Invoer voor wederuitvoer & $\begin{array}{r}\text { Percentage } \\
\text { importstroom in } \\
\text { totale invoer } \\
\text { product }\end{array}$ & $\begin{array}{r}\text { Bedrag } \\
\text { importstroom } \\
\text { (miljard euro) }\end{array}$ \\
\hline Fruit & 72 & 5,3 \\
\hline Sierteelt & 69 & 1,6 \\
\hline Landbouwmachines & 57 & 0,7 \\
\hline Bereidingen van groente en fruit & 54 & 1,6 \\
\hline Vis en zeevruchten & 51 & 1,1 \\
\hline \multicolumn{3}{|c|}{ Top 5 Invoer voor directe consumptie in Nederland } \\
\hline Bereidingen van graan, meel, melk & 43 & 1,0 \\
\hline Bereidingen van vlees en vis & 32 & 0,6 \\
\hline Zuivel en eieren & 30 & 1,3 \\
\hline Bereidingen van groente en fruit & 27 & 0,8 \\
\hline Vlees & 27 & 1,0 \\
\hline \multicolumn{3}{|c|}{ Top 5 Invoer voor consumptie in Nederland na verwerking in Nederland } \\
\hline Graan & 28 & 0,8 \\
\hline Vlees & 18 & 0,7 \\
\hline Natuurlijke vetten en oliën & 14 & 0,7 \\
\hline Zuivel en eieren & 13 & 0,6 \\
\hline Dranken & 13 & 0,6 \\
\hline \multicolumn{3}{|c|}{ Top 5 Invoer voor export na verwerking in Nederland } \\
\hline Graan & 64 & 1,8 \\
\hline Levende dieren & 53 & 0,6 \\
\hline Cacao en bereidingen & 52 & 2,2 \\
\hline Natuurlijke vetten en oliën & 43 & 2,3 \\
\hline Oliehoudende zaden en vruchten & 41 & 1,7 \\
\hline
\end{tabular}

Bron: CBS

\subsection{Herkomstlanden Nederlandse landbouwimport}

In figuur 9.1 staan de 20 belangrijkste herkomstlanden van de Nederlandse landbouwimport in 2020. Duitsland, België en Frankrijk zijn de belangrijkste herkomstlanden en de bestemming van de import uit deze landen is goed vergelijkbaar. Deze import is minder dan gemiddeld bestemd voor wederuitvoer, meer dan gemiddeld bestemd voor de Nederlandse markt (zowel direct als indirect) en gemiddeld wat betreft de verwerking van import voor het buitenland. De buurlanden zijn bovendien eerder bestemmingslanden dan herkomstlanden van Nederlandse wederuitvoer: wederuitvoer betreft vaker verre herkomstlanden waarbij de goederen in de Rotterdamse haven aankomen met landen dichtbij als bestemming.

Herkomstlanden bij de invoer voor wederuitvoer Indien de top 20 van herkomstlanden wordt gesorteerd naar het aandeel invoer voor wederuitvoer, dan komen vier landen naar boven die met name fruit naar Nederland exporteren. Het gaat om Peru en Chili (met name avocado's, maar ook druiven en mango's), Zuid-Afrika (onder andere druiven) en Spanje (o.a. avocado's en frambozen). Fruit is een typisch wederuitvoerproduct dat in de juiste condities over grote afstanden kan worden vervoerd.

Herkomstlanden bij de invoer voor directe consumptie in Nederland Gesorteerd op het aandeel import direct voor Nederlandse consumptie komen Italië, Polen en Chili naar boven. Bij de invoer uit Italië gaat het onder andere om gebrande koffie, deegwaren zoals pasta, Parmezaanse kaas en Italiaanse wijn. De Nederlandse consumptie uit Polen betreft met name sigaretten en in het geval van Chili gaat het vooral om avocado's, maar ook Chileense wijn.

Herkomstlanden bij de consumptie in Nederland na verwerking in Nederland Er zijn geen herkomstlanden waarbij heel forse percentages in Nederland worden geconsumeerd na be- of verwerking in Nederland. De hoogste percentages zien we terug bij Oekraïne, Duitsland en Frankrijk. In het geval van Oekraïne gaat het met name om mais en in minder mate zonnebloemzaadolie. De te bewerken import uit Duitsland en Frankrijk betreft met name granen, zoals tarwe, maar ook een aanzienlijke hoeveelheid Duitse kippen.

Herkomstlanden bij de export na verwerking in Nederland

Als het gaat om het herkomstland waarbij de import na bewerking in Nederland wordt uitgevoerd, dan blijkt bijna de helft van de import uit Indonesië en Maleisië (bekend van de import van palmolie), Oekraïne (met 
name mais) bestemd te zijn voor de export na bewerking in Nederland. Voor de import uit Ivoorkust (cacaobonen) is dat zelfs $60 \%$.

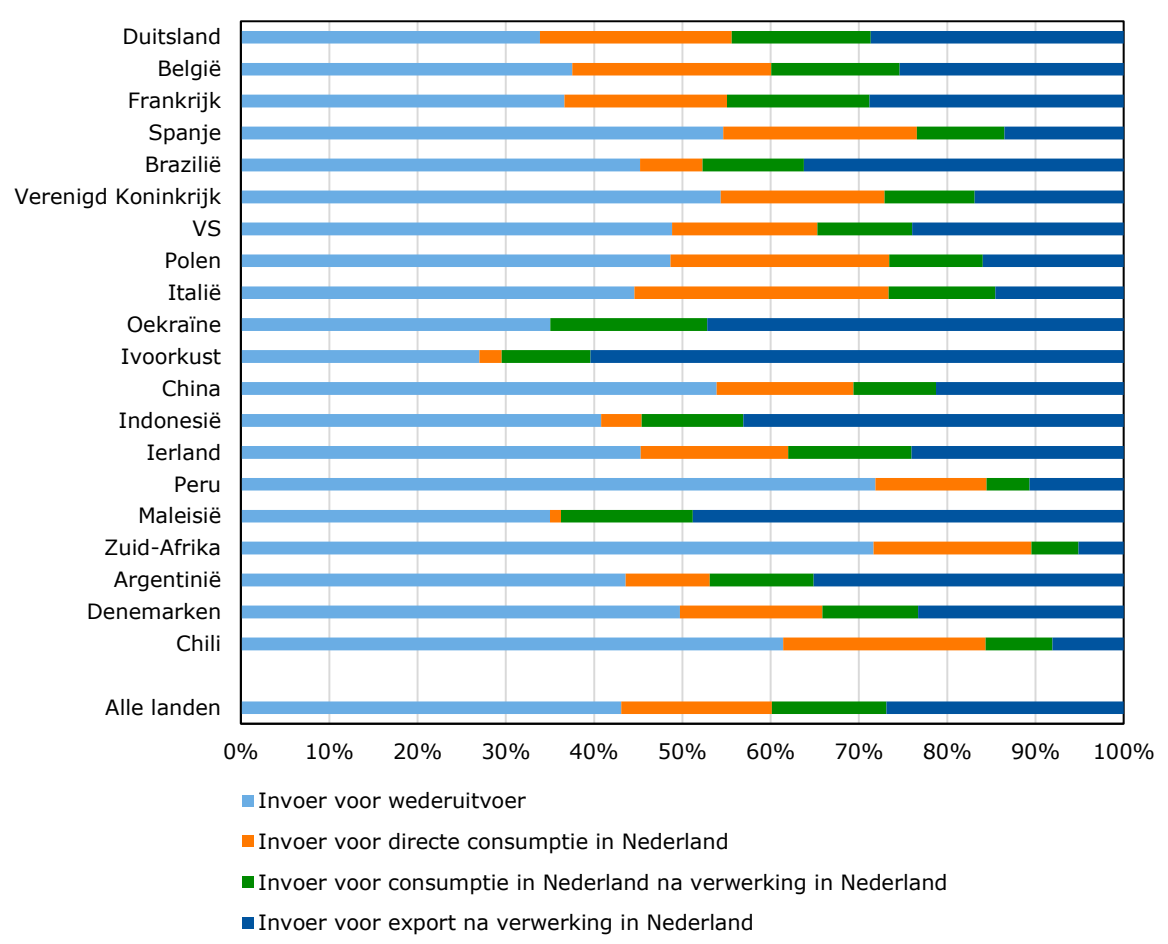

Figuur 9.1 Herkomstlanden (van groot naar klein) Nederlandse landbouwimport naar bestemming, 2020. Bron: CBS.

EU levert ook relatief meer voor de Nederlandse markt

EU-landen leveren absoluut, maar ook relatief meer aan de Nederlandse markt dan niet-EU-landen. Anders gezegd, een hoger percentage van de import uit EU-landen is direct of indirect bestemd voor consumptie in Nederland in vergelijking met de import uit landen buiten de EU. Nederland heeft als agrologistieke wereldspeler een belangrijke distributiefunctie voor andere Europese landen, zowel direct (als groot wederuitvoerland van bijvoorbeeld fruit) als indirect (als grote verwerker van mais, palmolie, cacao of soja). Dit zijn allemaal producten die met name uit landen buiten de EU komen. De verschillen zijn vooral zichtbaar bij de Nederlandse markt: $70 \%$ van de landbouwproducten die uiteindelijk in Nederland wordt geconsumeerd komt uit EU-landen, 30\% uit niet-EU-landen (zie figuur 9.2). Bij de gehele landbouwimport is de verhouding ongeveer $60-40 \%$.

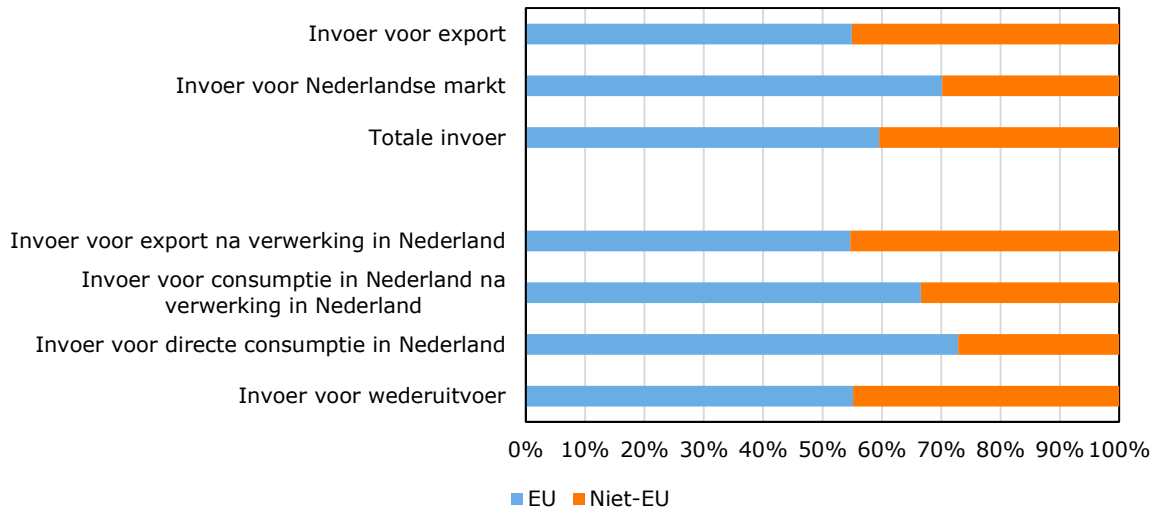

Figuur 9.2 Landbouwimport naar herkomst (EU/niet-EU) en bestemming, 2020. Bron: CBS 


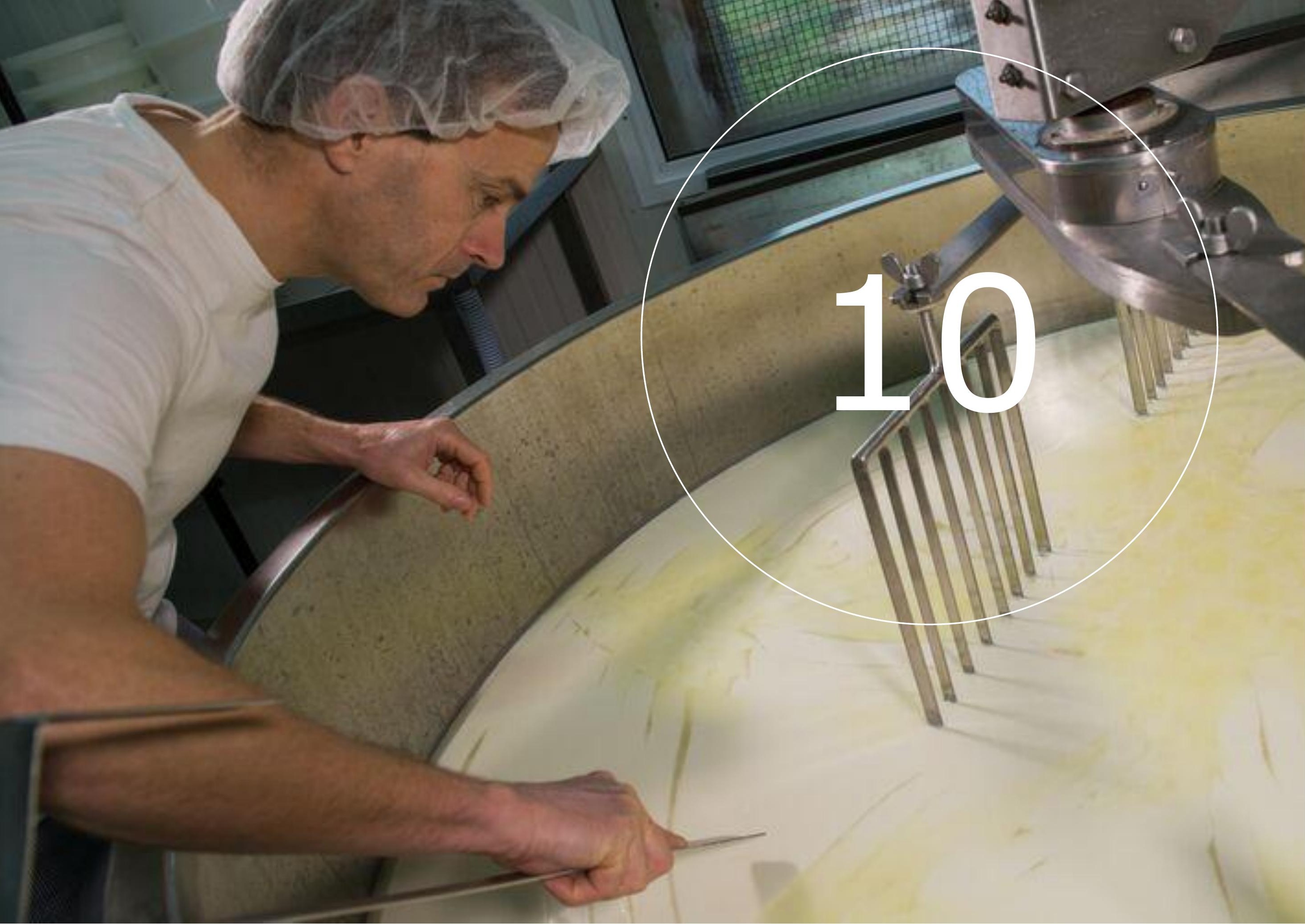




\section{Handel in biologische producten}

\subsection{Inleiding}

Naast cijfers over hoeveel en welke goederen over de wereld en tussen landen worden verhandeld, is er een groeiende behoefte om ook meer eigenschappen van deze handel te monitoren. Het gaat dan zowel om kenmerken van het product, als om het productieproces en de omstandigheden waaronder het product tot stand is gekomen. Hoe is een landbouwgoed, dat een land importeert of exporteert, gemaakt en met welke en hoeveel inputs is dat gedaan? Moet de EU eisen gaan stellen aan zijn import of quota instellen voor 'niet duurzame' producten? Zo wil het Europese parlement het verbeteren van de biodiversiteit niet alleen in de EU verbeteren maar ook onderdeel laten zijn van internationale handelsverdragen (Nieuwe oogst, 2021).

In dit hoofdstuk wordt inzicht gegeven in de biologische import in de EU vanuit derde landen, op basis van het Traces-systeem (zie kader). Dit is een van de weinige openbare bronnen waarbij kenmerken van producten worden gekoppeld aan de GN-handelscode. In het algemeen is er best veel bekend over landbouwgoederen en landbouwproductie, zoals informatie over de effecten op het milieu. Het probleem met deze informatie is veelal dat deze gefragmenteerd is en in verschillende databases is vastgelegd. Ook is de informatie meestal niet te koppelen aan specifieke productstromen, maar gaat het om gegevens over de gevolgen van de productie op nationaal of regionaal niveau (zie ook Ruster et al., 2021). In het kader van de op handende zijnde due diligence wetgeving, waarvan de kern is dat een bedrijf negatieve gevolgen van de bedrijfsactiviteiten op sociaal en milieugebied voorkomt dan wel aanpakt (zie paragraaf 11.2), zal informatie die is te koppelen aan specifieke productstromen steeds belangrijker worden. Vooralsnog is die informatie niet via één algemeen toegankelijke database voorhanden, zoals wel het geval is bij gegevens over handelsstromen.
In dit hoofdstuk wordt allereerst ingegaan op de importstromen van biologische producten op EU-niveau. Daarna volgt in paragraaf 10.3 een beschrijving van de importstromen naar Nederland. In de laatste paragraaf wordt op basis van de beschikbare gegevens een beeld gegeven van de handel in biologische producten buiten de EU. Bijlage 7 bevat als extra informatie structuurgegevens over de biologische sector in de EU.

\subsection{Biologische importstromen van de EU-27}

Op de informatie uit het Traces-systeem na, zijn er geen openbare cijfers over de handel in biologische producten tussen landen van de EU-27 en partnerlanden buiten de EU-27 (openbaar) beschikbaar. In dit hoofdstuk worden de meest recente beschikbare gegevens gebruikt uit de jaren 2018, 2019 en 2020.

Sinds 2018 worden importgegevens in volume vrijgegeven uit het Traces systeem (zie kader) en gepubliceerd door de EU. Hoewel dit systeem geen volledig beeld geeft, niet alle landen in de wereld gebruiken dit systeem, is het wel geschikt om de import in de EU-27 te monitoren. Hierop is één uitzondering, de import uit het VK was niet beschikbaar; er is dus sprake van enige onderschatting. Wellicht heeft de afwezigheid van de cijfers te maken met de uittreding van het Verenigd Koninkrijk uit de Europese Unie. De biologische handel tussen EU-27 landen onderling is echter niet openbaar, ook is er geen overzicht op wereldniveau.

In totaal werd in 2020 voor zo'n 181 miljoen ton aan landbouwgoederen geïmporteerd in de EU-27. Anderhalf procent ( 2,8 miljoen ton) hiervan valt in de categorie biologische producten. Dit aandeel is voor de drie jaar dat data beschikbaar zijn wel iets gestegen, maar het aandeel blijft afgerond $1,5 \%$ van het totaal. Overigens daalde het biologische importvolume in 2020 ten opzichte van 2019 met 2\% (zie tabel B6.1 in bijlage 6 voor een overzicht van de landen waarvoor gegevens beschikbaar zijn over de handel in biologische producten). 
Van het tropische fruit dat wordt geïmporteerd in de EU-27 is circa $10 \%$ biologisch. De op twee na belangrijkste biologische productgroep biet- en rietsuiker heeft net als tropisch fruit een aandeel van ongeveer $10 \%$ op de totale import. Biologische olijfolie is in importvolume bescheiden. Het aandeel ten opzichte van de totale import van olijfolie is met $16 \%$ juist het grootst. Bij andere biologische productgroepen ligt het aandeel tussen de $1 \%$ en $4 \%$. Tabel B6.2 (in bijlage 6) geeft een uitgebreide lijst met biologische aandelen op het importvolume.

Biologische producten het meest geïmporteerd uit Ecuador

In volume gemeten komen de meeste biologische producten in 2020 de EU binnen vanuit Ecuador (figuur 10.1), in 2018 en 2019 was dit nog China. Mogelijk heeft de coronacrisis en het gebrek aan geconditioneerde containers op de juiste plek en de hogere kosten van vervoer een rol gespeeld in de lagere importhoeveelheid vanuit China. China is gezakt naar plek drie. De Dominicaanse Republiek, waarvan de importhoeveelheden net als bij die van Ecuador in de drie beschikbare jaren sterk zijn gestegen, staat op nummer twee. Naast China daalt ook de import vanuit Oekraïne en Turkije. Andere landen die aan de EU leveren in deze top tien zijn India en Colombia. Van deze landen steeg de export richting de EU-27. Ook de import uit Togo stijgt, maar deze is van geringe omvang.

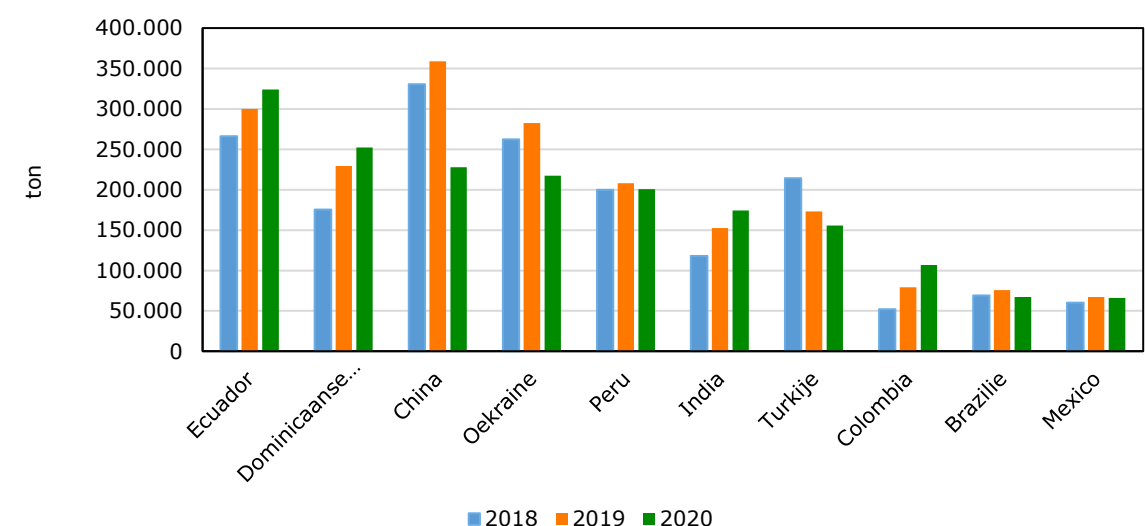

Figuur 10.1 Belangrijkste landen van herkomst van biologische producten van buiten de EU-27 landen (in ton)

Bron: Traces, bewerking Wageningen Economic Research.
Traces

Traces is het online platform van de Europese Commissie voor sanitaire en fytosanitaire certificering die vereist is voor de invoer van dieren, dierlijke producten, levensmiddelen en diervoeders van niet-dierlijke oorsprong en planten in de Europese Unie, en de handel binnen de EU en de EU-uitvoer van dieren en bepaalde dieren producten.

Tegenwoordig wordt Traces in ongeveer 90 landen gebruikt, met meer dan 55.000 gebruikers wereldwijd voor de afgifte van sanitaire en fytosanitaire certificaten en officiële documenten die nodig zijn voor invoer, uitvoer en intra-EU-bewegingen van levende dieren en goederen.

De belangrijkste doelstelling van Traces is het stroomlijnen van het certificeringsproces en alle gekoppelde invoerprocedures en het aanbieden van een volledig gedigitaliseerde en papierloze workflow.

Het vergemakkelijkt de uitwisseling van gegevens, informatie en documenten tussen alle betrokken handelspartijen en controleautoriteiten en vereenvoudigt en versnelt daarmee de administratieve procedures.

De mogelijkheid om alle bewegingen van dieren, dierlijke producten, levensmiddelen en diervoeders van niet-dierlijke oorsprong en planten heen en weer te traceren, draagt bij aan de vermindering van de impact van ziekteuitbraken en maakt een snelle reactie mogelijk in geval van ernstige risico's in de agri-voedselketen.

Het Traces-platform heeft als doel de samenwerking en coördinatie tussen de bevoegde autoriteiten van EU-landen en niet-EU-landen, maar ook tussen de handelaren zelf en hun bevoegde autoriteiten te verbeteren. Bij het nemen van een besluit over een zending worden de betrokken partijen geïnformeerd en hebben zij toegang tot de relevante documenten. Traces zorgt voor een snelle detectie van valse certificaten en draagt zo bij aan de bestrijding van voedselfraude en verbetert de samenwerking en samenwerking tussen autoriteiten.

Met de geïntegreerde statistische tool kunnen waardevolle gegevens worden geëxtraheerd met betrekking tot invoer in de EU, uitvoer uit de EU en handel binnen de Unie.

bron: https://www.nvwa.nl/onderwerpen/traces/toepassingen-traces 
Belangrijke herkomstlanden van buiten de EU voor reguliere (niet-biologisch gecertificeerde) goederen in de EU-27 zijn Brazilië, Oekraïne, Rusland, het Verenigd Koninkrijk, ${ }^{20}$ de VS, Argentinië, Canada en Indonesië. Het verschil in herkomstlanden komt voort uit een verschil in het productpakket.

Bananen veruit belangrijkste biologische importproduct

Het meest geïmporteerde biologische product in de EU-27 landen is de banaan met bijna een kwart van het totale volume in 2020. Andere belangrijke producten zijn veevoer in de vorm van perskoeken, sojabonen en koffie (figuur 10.2). De top tien producten heeft een aandeel van een kleine $60 \%$ in het totaal aan geïmporteerde biologische goederen.

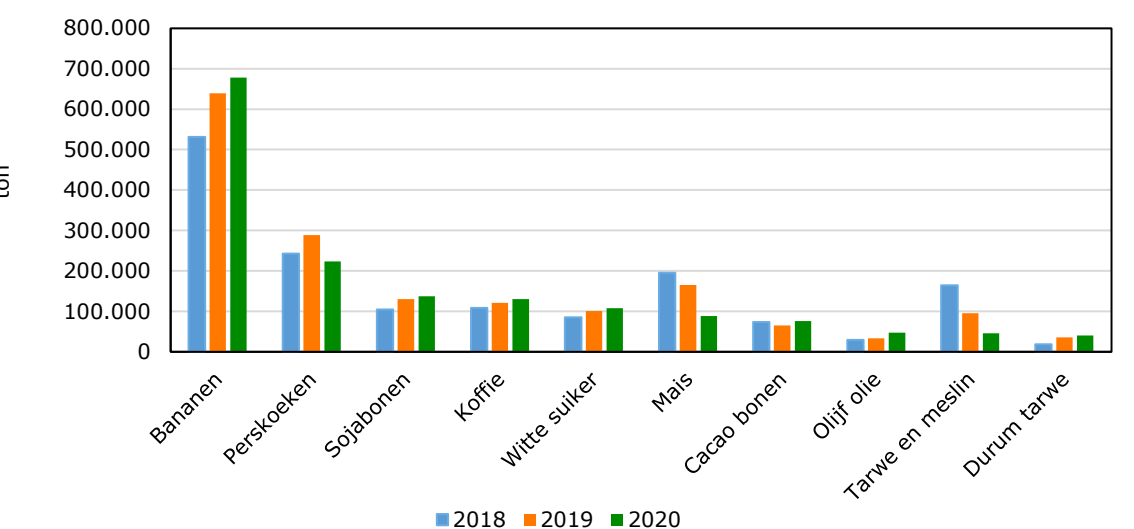

Figuur 10.2 Belangrijkste biologische importgoederen van buiten de EU-27 Bron: Traces, bewerking Wageningen Economic Research.

Uit zowel Ecuador als uit de Dominicaanse Republiek worden vooral bananen geïmporteerd. De Dominicaanse Republiek levert ook een beperkte hoeveelheid biologische cacaobonen. Uit China komt een wat breder productenpakket, maar toch bestaat het grootste deel uit perskoeken (uit soja). Gember is het tweede product dat uit China de EU-27 binnenkomt. Uit Oekraïne importeert de EU-27 vooral veel mais, tarwe en sojabonen. Uit Peru komen naast bananen vooral

\footnotetext{
${ }^{20}$ Voor het Verenigd Koninkrijk zijn geen gegevens beschikbaar over de handel in biologische producten.
}

biologische koffie, gember, cacao en avocado. India staat in de top tien van importlanden door een combinatie van perskoeken, sojabonen en witte suiker. Tenslotte komen uit Turkije durum tarwe, gedroogde linzen, sultana's en appelsap.

Controle op biologische handel door EU erkende organisaties in buitenland De biologische geïmporteerde producten moeten voldoen aan normen die gelijkwaardig zijn aan de normen die gelden in de EU voor biologische producten. Om dit te waarborgen zijn er procedures voor importeurs gemaakt. Deze procedures zijn afhankelijk van het land van herkomst. Bij een aantal landen zijn de normen en controlemaatregelen van de nationale controleorganen, waar certificering plaatsvindt, als gelijkwaardig beoordeeld aan die van de EU-27. Bij deze zogenaamde equivalente landen (Argentinië, Australië, Canada, Chili, Costa Rica, India, Israël, Japan, Tunesië, Korea, Nieuw Zeeland, Zwitserland en de VS) voert de door dat land aangewezen nationale autoriteit de controles uit. Vaak bestaan er aparte regelingen met dergelijke landen.

Bij andere landen zijn er onafhankelijke nationale instanties, erkend door de Europese Commissie, om er voor te zorgen dat biologische goederen voldoen aan de EU-normen en controlemaatregelen. Ook kunnen er nog aanvullende eisen gelden voor producten uit specifieke landen. Momenteel is dit het geval voor producten uit onder andere China, India, Moldavië, Rusland, Kazachstan en Oekraïne.

Export van biologische producten uit de EU-27 moet voldoen aan de eisen van het betreffende land. Voor importeurs of exporteurs van biologische goederen in Nederland is Skal de certificerings- en controle-instantie.

\subsection{Import van biologische goederen door Nederland}

De belangrijkste importeur van biologische landbouwgoederen uit landen van buiten de EU-27 is Nederland (figuur 10.3). Ruim 31\% van het totale geïmporteerde volume in de EU-27 werd in 2020 door Nederland ingevoerd. Duitsland en België volgen respectievelijk met ongeveer $18 \%$ en $11 \%$. Waar 
het importvolume voor Nederland en België wat zakte tussen 2019 en 2020, steeg de import van Duitsland, Frankrijk en Italië. De belangrijkste vijf importeurs hebben samen een importaandeel van tussen de 70 en $80 \%$.

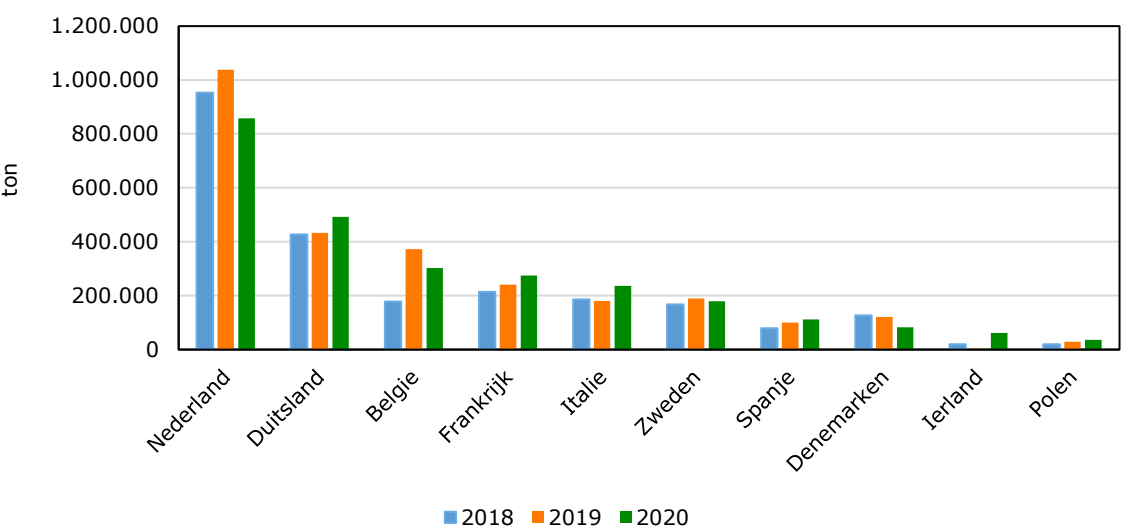

Figuur 10.3 Belangrijkste EU-importlanden van biologische producten van buiten de EU-27

Bron: Traces, bewerking Wageningen Economic Research.

Nederland importeert breed pakket aan biologische goederen

Het ingevoerde scala aan producten in Nederland groot. De belangrijkste producten verschillen echter niet veel van de in figuur 10.2 getoonde producten (figuur 10.4). Zo hebben de bananen ook in Nederland veruit het grootste aandeel in het totaal, namelijk $23 \%$. Perskoeken zijn goed voor $10 \%$ van het volume, mais en cacaobonen beide goed voor $6 \%$ van de totaal geïmporteerde biologische goederen. Ten opzichte van de gehele EU-27 komen koffie, durum tarwe en olijfolie niet in Nederlandse de top tien voor.

Sinaasappelsap, avocado's en grondnoten vervangen deze producten. Deze goederen komen echter wel op plek acht, negen en tien met aandelen van $2 \%$ of $1 \%$ in de totaal door Nederland geïmporteerde hoeveelheid. Hoewel het volume van anderen goederen nog beperkter is, importeert Nederland ruim 400 verschillende producten. Ook Duitsland importeert een breed scala aan biologische producten. De Belgische import is minder divers.
De daling van de Nederlandse import in 2020 is vooral toe te schrijven aan een veel lagere invoer van mais uit Oekraïne. Maar ook een lagere hoeveelheid van perskoeken, tarwe en zonnebloemzaden speelde een rol. De import van bananen bleef op peil. Het volume van cacaobonen en gember en avocado's en grondnoten nam ten opzichte van 2019 toe.

$\stackrel{5}{\circ}$

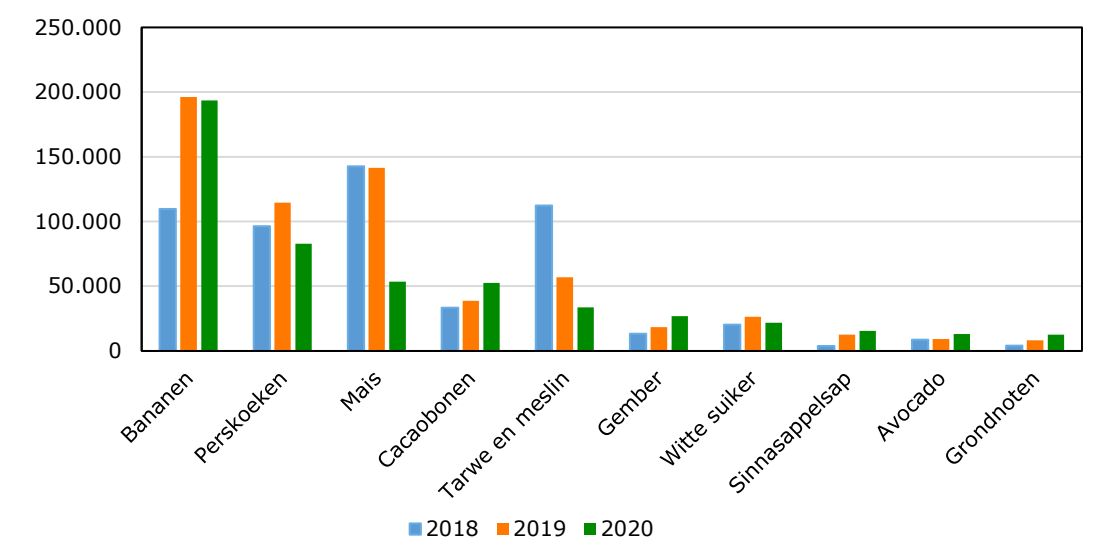

Figuur 10.4 Belangrijkste biologische importgoederen van buiten de EU-27 naar Nederland

Bron: Traces, bewerking Wageningen Economic Research.

\subsection{Handel in biologische goederen buiten de EU}

De International Federation of Organic Agriculture Movements (Ifoam)en de Research Institute of Organic Agriculture (FiBL) verzamelen onder andere wereldwijd data over de biologische markt. Veel van die data gaan over het areaal dat biologisch wordt geteeld, het aantal agrarische ondernemingen en welke omzet er is behaald in de supermarkt. Cijfers over de handel in biologische producten zijn echter beperkt. Naast de hiervoor genoemde data van de EU, wordt er door deze organisaties via enquêtes en nationale bronnen informatie verzameld. Vergelijken is lastig omdat de verzameling van data op verschillende manieren gebeurt. De handelsgegevens komen uit verschillende bronnen en zijn soms niet van jaar op jaar te vergelijken. Ook zijn de data 
verre van compleet in een aantal landen, jaren of stromen en zijn deze cijfers juist weer in euro' s en niet in volume zoals bij de EU-cijfers.

In bijlage 6 geeft tabel B6.1 een overzicht van de waarde van de import en export in biologische producten voor de landen waar gegevens over bekend zijn. Hieruit blijkt dat er tussen 2015 en 2019 voor een kleine 60 landen iets bekend is over de waarde van de biologische handel. Uit de cijfers kan voorzichtig worden opgemaakt dat de VS, Italië, Frankrijk, Denemarken, China en Nederland belangrijke landen zijn als het gaat om de biologische handel. Voor Nederland is dit belang gebaseerd op data van 2015.

Gegevens importen VS geven nader beeld

Uit de importcijfers van biologische producten van de VS blijkt dat Mexico, Peru, Italië, Argentinië, Brazilië, Ecuador, Colombia, Canada, Chili en Tunesië belangrijke aanvoerlanden zijn. Ongeveer een kwart van de waarde aan biologische goederen die Mexico exporteert, bestaat uit biologische avocado's. Peru exporteert vooral koffie. Uit Italië komt olijfolie terwijl Argentinië mais en soja exporteert. Brazilië levert suiker en honing aan de VS. Uit Ecuador en Colombia komen vooral bananen, terwijl Canada onder andere koffie, soja en bosbessen uitvoert. Ook uit Chili komen bosbessen en uit Tunesië komt olijfolie op de Amerikaanse markt. Nederland exporteert vooral paprika en koffie naar de VS. Voor biologische paprika is overigens Mexico hofleverancier voor de VS.

Volgens data van de FibL en Afoam is wereldwijd de VS veruit de belangrijkste afzetmarkt voor biologisch voedsel, gevolgd door Duitsland, Frankrijk, China, Canada, Zwitserland, het Verenigd Koninkrijk, Zweden en Spanje. 


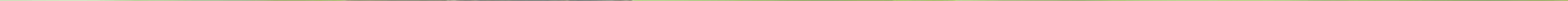




\section{Handel en internationale welvaart}

\subsection{Inleiding}

Het overheersende idee is dat liberalisatie van de handel goed is voor de welvaart, zowel in importerende als exporterende landen. Dit idee is gebaseerd op handelstheorieën over comparatieve voordelen, die suggereren dat het best kan worden geproduceerd in het land waar dat het beste kan - bijvoorbeeld door verschillen in klimaat of beschikbare arbeid -, en via ruilhandel producten kunnen worden verkregen die een land niet zelf kan produceren. Dit zorgt uiteindelijk voor meer specialisatie van productie in bepaalde delen van de wereld, en vaak specialisatie in bepaalde kleinere onderdelen van productieprocessen. Inmiddels bestaat zo'n $70 \%$ van de mondiale handel uit internationale waardeketens, waarbij producten een aantal landen passeren voordat een uiteindelijk product wordt ontwikkeld (OECD, 2020). Deze manier van handel drijven zou volgens de theorie ook leiden tot meer arbeid en daarmee vergrote welvaart in lage en midden-inkomenslanden.

Ook Nederland speelt een belangrijke rol in mondiale waardeketens, bijvoorbeeld als het gaat om het importeren en her-exporteren van tropische producten als cacao, palmolie, koffie en soja. Zo is Nederland wereldwijd ruim de grootste importeur van cacaobonen. Nederland importeert meer dan 2 keer zoveel als de VS, de op één na grootste importeur (Statista, 2021). Ook in de import van palmolie (Nederland derde invoerland ter wereld), sojabonen (vierde) en koffie (vijfde) speelt Nederland een belangrijke rol (CBS, 2019). Een groot deel van deze tropische producten wordt hier verwerkt of direct geëxporteerd, - vooral naar andere landen in Europa (zie ook paragraaf 9.3). Oftewel, tropische producten zijn belangrijk voor de Nederlandse economie en de Nederlandse consument. Maar hoe zorgen we dat de productie van dat reepje chocola of kopje koffie geen negatieve effecten heeft in de landen waar de grondstoffen voor die producten, zoals cacao en koffiebonen, vandaan komen?

\subsection{Internationaal maatschappelijk verantwoord ondernemen}

De laatste tijd worden mondiale waardeketens steeds meer onder de loep genomen. Zo groeit de bezorgdheid dat handelsliberalisatie leidt tot meer ongelijkheid binnen lage- en midden-inkomenslanden, waar de primaire grondstoffen voor onze producten vandaan komen. Uit een studie van de WTO blijkt bijvoorbeeld dat de voordelen van de huidige ketens vooral gelden voor hoogopgeleide arbeiders en niet voor de allerarmsten (Helpman, 2016), tegen de voorspellingen van handelstheorieën in (WTO, 2019). Ook tussen landen ontstaat meer ongelijkheid: handelsverdragen worden gesloten op het moment dat landen op verschillende momenten in hun economische ontwikkeling zitten, waardoor specialisatie in bepaalde productieprocessen optreedt - zoals primaire productie -, waarvan het comparatieve voordeel nooit op kan tegen dat van een ander land, dat bijvoorbeeld gespecialiseerd is in het ontwikkelen van technologie. Daarnaast roepen mondiale waardeketens vragen op over de verantwoordelijkheden voor bedrijven en handelaren: primaire producten als cacao en koffiebonen worden vaak gerelateerd aan negatieve gevolgen voor mens en milieu, zoals ontbossing, kinderarbeid en het gebrek aan leefbare inkomens voor boeren.

Maar er lijken ook mogelijkheden: mondiale waardeketens en de daarmee gepaarde afhankelijkheid tussen landen zouden ook juist een grote rol kunnen spelen in het verbeteren van bovengenoemde omstandigheden. Zo zouden bedrijven - mits de goede prikkels en wet- en regelgeving worden aangeboden - strengere normen voor sociale en milieu-standaarden kunnen aanhouden (Bradford, 2020). De laatste jaren komen dit soort vragen steeds meer op in het publieke en politieke debat, ook in Nederland. Zo is er Nederlands beleid op het gebied van internationaal maatschappelijk verantwoord ondernemen (IMVO) voor eerlijkere waardeketens en wordt er steeds meer aandacht besteed aan zaken als kinderarbeid en een leefbaar inkomen voor boeren 
(Rijksoverheid, n.d.). De Europese Unie bereidt momenteel wetgeving voor om verantwoord ondernemen zelfs te verplichten (EP, 2020; EU, 2021). Een belangrijk onderdeel hiervan is dat bedrijven hun handelsketen inzichtelijk en traceerbaar maken: hoe en waar worden de producten gemaakt, en welke risico's en onwenselijke gevolgen hebben deze activiteiten? Een recent wetsvoorstel van de Europese Commissie suggereert bijvoorbeeld dat handelaren verplicht moeten worden om producten die geassocieerd worden met ontbossing - zoals cacao, koffie, palmolie en soja - onderhevig te maken aan strenge traceerbaarheidseisen, om te zorgen dat er geen producten op de Europese markt komen die direct of indirect door ontbossing zijn verkregen (EC, 2021). Maatschappelijke organisaties kijken hoopvol uit naar deze wetgeving, al zal onderzoek moeten aantonen welke daadwerkelijke impact het heeft op verduurzaming van bestaande ketens: het risico bestaat dat ketens zich slechts zullen verleggen.

\subsection{Instrumenten voor maatschappelijk verantwoord ondernemen}

Naast verplichte wet- en regelgeving bestaan er andere initiatieven om problemen in de keten aan te pakken. ${ }^{21} \mathrm{Er}$ zijn bijvoorbeeld diverse duurzaamheidskeurmerken. Een certificaat of keurmerk toont aan dat een product aan bepaalde eisen voldoet. Hier horen het monitoren en auditen van het productieproces bij, vaak door een onafhankelijke derde partij (UNCTAD, 2021). Bedrijven kunnen zich vrijwillig bij een keurmerk aansluiten. Er bestaan genoeg prikkels voor bedrijven om dit te doen, bijvoorbeeld om bescherming of opbouw van de reputatie van een merk. Keurmerken voor tropische producten zijn Fairtrade en Rainforest Alliance. Fairtrade werkt met een minimumprijs als vangnet en een premie bovenop de minimumprijs. Het idee van de minimumprijs is dat wanneer de wereldmarktprijs van een product onder deze prijs duikt, de minimumprijs van kracht is, waardoor stabiliteit aan inkomsten wordt gegarandeerd voor de boer (UNCTAD, 2021). Of een boer recht heeft op deze minimumprijs, of op een aanvullende premie, hangt van twee zaken af. Ten eerste de vraag of de productieprocessen aan de eisen van het keurmerk voldoen en ten tweede, in het geval van Rainforest Alliance, of

\footnotetext{
${ }^{21}$ Zie bijvoorbeeld Outcomes of deforestation-free commodity value chain approaches - WUR.
}

de gecertificeerde boeren een onderhandelingspositie hebben die het mogelijk maakt om een premie te krijgen die leidt tot hogere betalingen per kilo.

De Nederlandse overheid verplicht bedrijven niet om zich aan een keurmerk te verbinden. Wel speelt de overheid een faciliterende rol in het stimuleren van duurzamere ketens. Zo tekende de Nederlandse cacaosector in samenwerking met de overheid in 2020 een intentieverklaring om te streven naar een leefbaar inkomen voor cacaoboeren in 2030 , naar een einde aan cacaogerelateerde ontbossing in 2025 en naar effectieve maatregelen tegen kinderarbeid in 2025 (Dutch Initiative on Sustainable Cocoa, 2020). Onder duurzaam wordt in dit geval verstaan dat de cacaoproductie voldoet aan bepaalde - en controleerbare - principes, zoals transparantie, fatsoenlijke arbeidsomstandigheden en behoud van biodiversiteit. Naast certificering dragen verschillende beleidsprogramma's van bedrijven en NGO's ook bij aan duurzaamheid, al is de impact daarvan vaak onbekend. Inmiddels is het aandeel (zichtbaar) duurzame cacao in de Nederlandse supermarkten zo'n 70\% (De Rooij et al., 2020). Ook voor andere tropische producten groeit de consumptie van producten met certificering. Tussen 2019 en 2020 kenden Fairtrade en Rainforest Alliance groeiende verkoopcijfers: consumentenbestedingen aan Fairtrade stegen met ruim $19 \%$, bestedingen aan Rainforest Alliance zelfs met 40\% (Logatcheva, 2020).

Keurmerken helpen, maar zijn geen garantie voor behalen duurzaamheidsdoelen

Het feit dat een product een keurmerk heeft, is niet altijd een garantie dat de duurzaamheidsdoelen daadwerkelijk gehaald worden. Hoewel er positieve effecten bekend zijn van certificering, bijvoorbeeld op inkomens van boeren en arbeidsomstandigheden, treden deze effecten niet overal op of zijn ze niet overwegend positief (Van Oorschot et al., 2015; Oya et al., 2017). Studies naar de effecten van certificering vinden onder andere dat de kleinste en armste producenten de hoogste kosten ondervinden om te voldoen aan de duurzaamheidseisen (UNCTAD, 2021). Deze boeren, die het meeste baat zouden moeten hebben bij de positieve effecten van deze eisen, vallen zo stelselmatig buiten de boot. Ook worden producenten niet altijd even goed betrokken bij de ontwikkeling van de duurzaamheidseisen, waardoor zij soms geen inspraak hebben in het proces (Schleifer et al., 2019). Bovendien houden 
studies naar de effecten van certificering niet altijd rekening met belangrijke trade-offs die kunnen optreden tussen sociale en milieuaspecten (Traldi, 2021). De laatste tijd kiezen steeds meer bedrijven voor het opzetten van hun eigen duurzaamheidsprogramma's, waar geen controle door een derde partij aan verbonden is (UNCTAD, 2021). Dit zou het nog moeilijker kunnen maken de positieve of negatieve effecten van die programma's vast te stellen.

Een voorbeeld van een van de doelen van duurzaamheidseisen waar tot nu toe weinig progressie is geboekt is het verminderen van armoede van boeren. Zo blijkt dat hoewel gecertificeerde boeren hun inkomsten van de verkoop van producten wel verhogen, het geen positief effect heeft op het algehele inkomen van het huishouden (Oya et al., 2017). Dit komt overeen met WUR-onderzoek over het bereiken van een leefbaar inkomen voor cacaoboeren, waaruit blijkt dat zelfs als de prijzen voor het product stijgen en de prijspremiums bij de boeren terechtkomen, nog steeds veel boeren niet zullen uitkomen op een leefbaar inkomen. De reden hiervoor is dat het verhogen van de prijs per kilo de grootste voordelen heeft voor de boeren die al in de hogere inkomensgroepen vallen, omdat hun productievolume een stuk hoger ligt (Waarts et al., 2019). Of een boer wel of niet tot een leefbaar inkomen kan komen ligt dus voor een groot deel aan de grootte van de cacaoboerderijen en de productie per hectare: productievolumes van kleine boeren zijn simpelweg te laag, zelfs met een prijspremie. Ondanks certificering en andere interventies is de productiviteit per hectare van deze kleinere boeren in de laatste jaren niet of nauwelijks gestegen omdat boeren weinig geld kunnen investeren. Bovendien hebben deze boeren vaak weinig andere economische mogelijkheden, waardoor er een te grote afhankelijkheid van één product cacao - ontstaat (Waarts en Kiewisch, 2021).

Brede samenwerking noodzakelijk

Naast de uitdagingen om certificering ook voor de kleine ondernemers te laten werken, maakt het feit dat mondiale waardeketens zo complex zijn de problematiek nog ingewikkelder. Veel internationale bedrijven hebben duizenden toeleveranciers, die soms zelf ook diensten uitbesteden (UNCTAD,
2021). In de cacaoketen zijn producten soms moeilijk herleidbaar, omdat er meerdere tussenpersonen aan te pas komen (Cordes et al., 2021). De oplossing lijkt vaak simpel: wanneer de consument een hogere prijs betaalt voor een reep chocola en bedrijven een hogere prijs voor cacao, verdient het merendeel van de boeren een leefbaar inkomen. Prijsverhoging levert op korte termijn meer inkomen op, maar voor de allerarmsten die kleine volumes produceren is die inkomensstijging marginaal. In hogere prijzen alleen zit daarom de oplossing niet. Bij het verhogen van prijzen voor grote groepen moet bovendien worden uitgekeken voor productieoverschot, wat prijzen weer zou drukken als beleid er niet voor zorgt dat het aanbod niet sneller stijgt dan de vraag (Waarts et al., 2019).

Daarbij is armoede een complex probleem wat een bredere aanpak nodig heeft. Voor veel boeren zal primaire productie van grondstoffen nooit genoeg kunnen opleveren om uit een situatie van armoede te komen vanwege kleine arealen en weinig middelen om te investeren (Waarts en Kiewisch, 2021). Voor deze boeren zullen of de productievolumes flink omhoog moeten - wat alleen zou kunnen door extra land te genereren en meer te investeren - of andere economische perspectieven moeten worden gecreëerd op de boerderij of elders. Boeren kunnen bijvoorbeeld betaald worden als rentmeester voor bosbescherming en koolstofvastlegging. Zo zijn boeren minder afhankelijk van cacaoprijzen en kunnen ze via een andere financieringsroute meer mogelijkheden krijgen. Bedrijven alleen zullen deze veranderingen niet kunnen bewerkstelligen, al hebben ze een belangrijke rol als inkoper.

Overheden hebben een rol om condities te creëren voor de boeren om een leefbaar inkomen te kunnen verdienen. Daarbij zullen in de toekomst wellicht lastige politieke keuzes moeten worden gemaakt, bijvoorbeeld door kleine boeren te stimuleren andere activiteiten te verrichten. Dit zou betekenen dat in brede zin hervormingen plaats moeten vinden om meer economische mogelijkheden te creëren. Overheden van producerende en importerende landen, bedrijven, maatschappelijke organisaties, en producenten zullen de handen meer intensief ineen moeten slaan om dit te bewerkstelligen. 


\section{Literatuur en websites}

\section{Hoofdstuk 2 De Nederlandse handel in landbouwgoederen}

AD (2021). Website: Boodschappen fors duurder: 'Gemiddeld huishouden honderden euro's extra kwijt' | Koken \& Eten |AD.nl

CBS (2020). Website: Handelsoverschot stabiel ondanks corona (cbs.nl), geraadpleegd op 22 december 2021

CBS (2021a). Internationale handel; in-. (weder)uitvoer, SITC (1 digit), landen(groepen). [Dataset]. Geraadpleegd op 22 december 2021

CBS (2021b). Website: Economisch belang export van Nederlandse makelij afgenomen (cbs.nl), geraadpleegd op 30 november 2021

Floridata (2021). Website: Dikke plus voor de bloemen- en plantenexport Floridata | Hét onafhankelijke dataplatform voor sustainable sourcing, debiteuren- en marktinformatie in de sierteeltsector.

Food and Agriculture Organization of the United Nations (FAO, 2021). Website: FAO - News Article: Global food prices rise at rapid pace in May, geraadpleegd op 30 november 2021

Jukema, G.D., P. Ramaekers en P. Berkhout (2021). De Nederlandse agrarische sector in internationaal verband - editie 2021.

Wageningen/Heerlen/Den Haag, Wageningen Economic Research en

Centraal Bureau voor de Statistiek

\section{Hoofdstuk 3 Herkomst en bestemming van Nederlandse handel in} landbouwgoederen

CBS (2020). Website: Import sojabonen uit Brazilië 40 procent hoger (cbs.nl), geraadpleegd op 30 november 2021

CBS (2021). Website: Verdiensten aan export van machines en voeding naar China sterk gegroeid (cbs.nl), geraadpleegd op 30 november 2021

\section{Hoofdstuk 4 De handel uitgesplitst naar handelsgroepen}

Bloemenbureau (2021).

https://www.bloemenbureauholland.nl/perskalender/uitkomstenonderzoek-planten-op-de-thuiswerkplek
Boerenbusiness.nl (2021) FrieslandCampina zet mes in productie Borculo Nieuws Babymelkpoeder | Boerenbusiness. $n \mid$

MVO (2021).

https://mvo.nl/media/duurzaamheid/biobrandstoffen/mvo brochure Idquo de waarde van plantaardige en dierlijke vetten en olien voor de bioba sed economy nieuw.pdf

RIVM (2021). https://www.rivm.nl/green-deal-duurzame-zorg/gezondheidbevorderen-door-goede-leefomgeving-zorginstellingen/natuur/plantenvoor-prima-binnenklimaat

Schiphol (2021). https://www.schiphol.nl/nl/schiphol-group/pagina/verkeeren-vervoer-cijfers/

\section{Hoofdstuk 6 De Nederlandse landbouwhandel met het Verenigd}

\section{Koninkrijk 2015-2021}

ASD Group (2021, 9 november). Brexit: Wat Zijn De Regels Voor Het Importeren Of Exporteren Van Levende Dieren Van En Naar Het Verenigd Koninkrijk?

Cheptea, A., M. Huchet en L. Henry (2021). 'How will Brexit affect the patterns of European agricultural and food exports?'. In: European Review of Agricultural Economics, 48(5), 1031-1073

Choi, H. S., T. Jansson, A. Matthews en K. Mittenzwei (2021). European Agriculture after Brexit: 'Does Anyone Benefit from the Divorce?'. In: Journal of Agricultural Economics, 72(1), 2021, 3-24

Dodde, H. (2021, 13 juli). Britten sluiten grenzen voor pootgoed uit EU. Nieuwe Oogst, Akkerbouw

Douch, M. en T. Huw Edwards (2021). The bilateral trade effects of announcement shocks: 'Brexit as a natural field experiment'. In: Journal of Applied Econometrics, 1-25

EFA (2021). Brexit: UK bans the import of minced meat. European Food Safety Agency: Parma, Italië

Elms, D. (2020, 10 januari) Regulatory divergence: a business nightmare. Singapore: Asian Trade Centre 
Evofenedex (2021, 15 september). Voorvermelding landbouwproducten naar VK verschoven naar 1 januari.

Floridata (2021). Dikke plus voor de bloemen- en plantenexport.

Franssen, L., O. Lemmers, L. Prenen en K.F. Wong (2020a). 'Verenigd Koninkrijk afhankelijker van Europese Unie dan eerder gedacht.' In: Economisch Statistische Berichten, 105(4786), 268-271

Franssen, L., M. van den Berg en M. Jaarsma (2020b). 'Afwijkende regelgeving na Brexit kan exporteurs flink op kosten jagen.' In: Economische en Statistische Berichten (ESB)

Graziano, A., K. Handley en N. Limao (2018). Brexit uncertainty and trade disintegration. NBER

Working Paper no. 25334. Cambridge, VS: National Bureau of Economic Research.

Jukema, G.D., P. Ramaekers en P. Berkhout (2021). De Nederlandse agrarische sector in internationaal verband - editie 2021.

Wageningen/Heerlen/Den Haag, Wageningen Economic Research en Centraal Bureau voor de Statistiek

LNV (2021a, 9 april). Meerderheid Nederlandse en Britse bedrijven ervaart last van Brexit. Den Haag: Ministerie van Landbouw, Natuur en Voedselkwaliteit, Agroberichten Buitenland

LNV (2021b, 20 april). Veel zorg over pootgoedhandel met VK. Den Haag: Ministerie van Landbouw, Natuur en Voedselkwaliteit, Agroberichten Buitenland

Matthews, A. (2017). Research for AGRI Committee - Possible Transitional Arrangements Related to Agriculture in the Light of the Future EU - UK Relationship: Institutional Issues. Brussel: European Parliament, Policy Department for Structural and Cohesion Policies

NAO (2021). The UK border: Post UK-EU transition period. Report by the Comptroller and Auditor General, session 2021-22.

NVWA (2020a). Importeren dieren en dierlijke producten uit Verenigd Koninkrijk vanaf 1 januari 2021.

NVWA (2020b). Importeren planten en plantaardige producten uit Verenigd Koninkrijk na Brexit.

NVWA (2021a). Exporteren dierlijke producten naar Verenigd Koninkrijk vanaf 1 januari 2022 | Brexit | NVWA. Geraadpleegd op 23 december 2021

NVWA (2021b). Voor welke producten heb ik een fytosanitair certificaat nodig bij export naar het Verenigd Koninkrijk? | Brexit | NVWA. Geraadpleegd op 23 december 2021
NVWA (2021c). Certificaat- en inspectieplichtige producten bij import.

O'Carroll, L. (2021). British food and drink exports to EU fall by $£ 2 b n$ in first quarter of 2021.

ONS (2021a). Did UK firms stockpile items ahead of the Brexit deadline? Newport/Titchfield/London: Office for National Statistics

ONS (2021b). Trade in goods: country-by-commodity imports. [Dataset]. Geraadpleegd op 10 december 2021. Newport/Titchfield/London: Office for National Statistics

RVO (2021a). Exporteren naar het VK? Regel dit voor 1 januari 2022 | RVO.nI | Rijksdienst. Geraadpleegd op 23 december 2021

RVO (2021b, 15 september). VK stelt nieuwe grenscontroles voor EUproducten uit.

Schouten, C. (2021, 24 september). Beantwoording schriftelijke vragen sluiting van grenzen in Groot-Brittannië voor de invoer van pootgoed uit de Europese Unie. [Kamerbrief].

Smid, T. en G. Frankena (2021). 'Britse handel verlegt zich naar landen buiten de Europese Unie.' In: Economisch Statistische Berichten

Wright, O. (2021). Tonnes of meat rotting at the border due to Brexit red tape. The Times

WTO (2021). Principles of the trading system. Genève, Zwitserland: Wereldhandelsorganisatie

\section{Hoofdstuk 7 De Nederlandse handel in landbouwgoederen en twee jaar}

\section{coronapandemie}

Bakker, K. (2021, 22 juni). Hierdoor blijven de logistieke kosten hoog. Foodbusiness, Achtergrond logistiek.

Berkhout, P., R. Bergevoet, A. Beldman, J. Benninga, M. Benus, N. Bondt, A. ten Brummelhuis, S. van den Burg, P. van Dalfsen, Y. Dijkxhoorn, M. Groot, H. van Horne, R. Hoste, J. Jager, B. Janssens, A. Jellema, H. Kortstee, H. van der Meulen, A. Mol, E. Poot, L. Puister-Jansen, P. Ravensbergen, P. Smit en R. Stokkers (2020). De impact van de coronacrisis op het Nederlandse agrocomplex. Wageningen: Wageningen Economic Research, onderdeel van Stichting Wageningen Research

Berkhout, Petra, Harold van der Meulen, Pascal Ramaekers (2021). Staat van Landbouw en Voedsel; Editie 2021. Wageningen/Heerlen/Den Haag, Wageningen Economic Research en Centraal Bureau voor de Statistiek, Rapport 2022-013 
CBS (2020a). Supermarkten in tweede week maart meer omzet dan in week voor kerst. Den Haag/Heerlen/Bonaire: Centraal Bureau voor de Statistiek

CBS (2020b). Inkomsten landbouwsector in 2020 lager door corona. Den Haag/Heerlen/Bonaire: Centraal Bureau voor de Statistiek

CBS(2021a). Detailhandel: recordgroei in 2020, krimp in december. Den Haag/Heerlen/Bonaire: Centraal Bureau voor de Statistiek

CBS (2021b). Bbp, productie en bestedingen; kwartalen, mutaties, nationale rekeningen. [Dataset]. Geraadpleegd op 10 december 2021

CBS (2021c). De Nederlandse economie in 2020. Den Haag/Heerlen/Bonaire: Centraal Bureau voor de Statistiek

CBS(2021d). Inkomsten landbouwsector 1 procent hoger in 2021. Den Haag/Heerlen/Bonaire: Centraal Bureau voor de Statistiek

CBS (2021e). Landbouw; output goederen en diensten, nationale rekeningen. [Dataset]. Geraadpleegd op 22 december 2021

Creemers, S., H. Draper en M. Jaarsma (2021). 'Nederlandse handel tijdens crises'. In S. Creemers, M. Jaarsma en J. Rooyakkers (Red.), Internationaliseringsmonitor, vierde kwartaal: Exogene schokken. Den Haag/Heerlen/Bonaire: Centraal Bureau voor de Statistiek

Europese Commissie (2020). Coronavirus: Commission presents practical guidance to ensure continuous flow of goods across EU via green lanes. Brussel: Europese Commissie

EVMI (2020, 03 maart). Coronavirus zorgt voor tekort aan koelcontainers. Expertisecentrum Voedingsmiddelenindustrie

FAO (2021). Agricultural trade \& policy responses during the first wave of the COVID-19 pandemic in 2020. Rome: Food and Agriculture Organization of the United Nations

Heel, Van, L. (2021, 20 augustus). Zeecontainers en waarom er 'van alles' duurder gaat worden... De Ondernemers, Nieuws Logistiek en Transport

ING (2021). De voedingssector na corona: Afzetmarkt voor voedingsindustrie en -handel is structureel veranderd. ING Economisch Bureau

Jukema, G.D., P. Ramaekers en P. Berkhout (2021). De Nederlandse agrarische sector in internationaal verband - editie 2021.

Wageningen/Heerlen/Den Haag, Wageningen Economic Research en Centraal Bureau voor de Statistiek

Knopers, F. (2021, 11 juni). Kosten containervervoer van China naar Europa stijgen naar $\$ 10.000$. Geotrendlines

LogistiekProfs (2021, 01 september). Hoge transportkosten en grondstofprijzen nopen winkelketens tot reshoring.
Multifix Group (2021, 23 februari). Waarom zijn de transportkosten vanuit China zo hoog?

New Zealand Embassy (2020). European Union: The Impact of Covid-19 on Agricultural Markets Market Report. Brussel: New Zealand Foreign Affairs \& Trade

NT (2020, 20 oktober). Tekort reefercontainers 'houdt zeker 3 tot 4 jaar aan'. Nieuwsblad Transport

OECD (2021a). Keep calm and carry on feeding: Agriculture and food policy responses to the COVID-19 crisis. Parijs: Organisation for Economic Cooperation and Development

OECD (2021b). COVID-19 and food systems: short- and long-term impacts. Parijs: Organisation for Economic Co-operation and Development

Pluimveebedrijf (2020, 2 maart). Tekort aan koelcontainers raakt Nederlandse food-bedrijven.

UNCTAD (2021). High freight rates cast a shadow over economic recovery. Genève, Zwitserland: United Nations Conference on Trade and Development

WUR (2020). Het Nederlandse voedselsysteem na Corona. Wageningen: Wageningen University \& Research

\section{Hoofdstuk 8 Handelsbeleid in de landbouw}

Berkhout, P. en S. van Berkum (2020). 'Behoud landbouwexport vergt sterkere milieunormen in handelsakkoorden Europa'. In: ESB, 105(4791S), 12 november 2020 , p. $70-74$

Broom, D.M. (2017). Animal welfare in the European Union. Study for the Peti Committee. Directorate-general for Internal Policies. Te vinden op www.europarl.europa.eu.

BuZa (ministerie van Buitenlandse Zaken). Van voorlichten tot verplichten. Een nieuwe impuls voor internationaal maatschappelijk verantwoord ondernemerschap. Den Haag, 2020

EC (European Commission) (2020). Van boer tot bord. ons voedsel, onze gezondheid, onze planeet, onze toekomst. Naar een gezonder en duurzamer EU-voedselsysteem, een hoeksteen van de Europese Green Deal. Brussel, $\operatorname{COM}(2020) 381$ final

EU (2021). EU Code of Conduct on responsible food business and marketing practices. Via: Code of Conduct (europa.eu)

EC (2021). Proposal for a Regulation of the European Parliament and of the Council on the making available on the Union market as well as export

100 | Wageningen Economic Research Rapport 2022-001 
from the Union of certain commodities and products associated with deforestation and forest degradation and repealing regulation (EU) No 995/2010. November 2021. Retrieved from:

https://ec.europa.eu/environment/publications/proposal-regulationdeforestation-free-products en

Europese Commissie (2021b). Vragen en antwoorden over de nieuwe regels voor ontbossingsvrije producten. 17 november 2021. Geraadpleegd van: https://ec.europa.eu/commission/presscorner/detail/nl/qanda_21 5919

Franssen, L. en A. Mounir (2021). 'Importtarieven, NTM's en exportkwaliteit'. In S. Creemers, M. Jaarsma en J. Rooyakkers (Red.), Internationaliseringsmonitor, derde kwartaal: Niet-tarifaire maatregelen; een investering in kwaliteit? Den Haag/Heerlen/Bonaire: Centraal Bureau voor de Statistiek

Ghodsi, M., J. Grübler en R. Stehrer (2016). Estimating Importer-Specific Ad Valorem Equivalents of Non-Tariff Measures. Working Paper no. 129. Wenen: Wiener Institut für Internationale Wirtschaftsvergleiche (wiiw)

Ghodsi, M. (2021). Exploring 'Non-Tariff Measures Black Box': Whose Regulative NTMs on Which Products Improve the Imported Quality? Working Paper no. 195. Wenen: Wiener Institut für Internationale Wirtschaftsvergleiche (wiiw)

Gooren, P. en R. Huige (2013). 'Het WTO-perspectief'. In: G. Meester, P. Berkhout en L. Dries (editors) (2013). EU-beleid voor landbouw, voedsel en groen. Wageningen Academic Publishers, Wageningen

Hoekman, B. en A. Nicita (2018). 'Non-tariff measures and trade facilitation: WTO disciplines and policy space for development'. In UNCTAD (eds.) NonTariff Measures: Economic Assessment and Policy Options for Development. Genève: UNCTAD

ITC (2021). International Trade Centre, met handelsdata; intracen.org/itc OESO (Organisatie voor Economische Samenwerking en Ontwikkeling) (2018) Due Diligence Guidance for Responsible Business Conduct

UN (United Nations) (2011) guidingprinciplesbusinesshr en.pdf (ohchr.org) WTO, Agreement on Agriculture 1995; https://www.wto.org/english/docs e/legal e/legal e.htm\#ag

WTO (2019) EU Trade Policy Review. WTO | Trade policy review -European Union (formerly EC) 2020

\section{Hoofdstuk 9 Import naar bestemming}

Aerts, N., T. Bohn, P. Ramaekers en K.F. Wong (2021). Handel in goederen met grote milieu-impact. Hoofdstuk 3 van 'Internationaliseringsmonitor 2021, tweede kwartaal: Handel en milieu'. Den Haag/Heerlen/Bonaire: Centraal Bureau voor de Statistiek

Agrio (2020). Website: https://www.vee-engewas.nl/site/assets/files/0/02/98/774/infographic-totaal.pdf, geraadpleegd op 12 oktober 2021

Bohn, T., T. Notten en K.F. Wong (2021). Nederland in internationale waardeketens. Hoofdstuk 6 van 'Nederland Handelsland: export, import en investeringen', editie 2021. Den Haag/Heerlen/Bonaire: Centraal Bureau voor de Statistiek

CBS (2019). Website: https://www.cbs.nl/nl-nl/nieuws/2019/31/nederlandgrootste-importeur-cacaobonen, geraadpleegd op 12 oktober 2021

CBS (2020). Website: https://www.cbs.nl/nl-nl/nieuws/2021/07/avocadoimport-groeit-met-19-procent-in-2020, geraadpleegd op 12 oktober 2021

CBS (2021b). Website: https://www.cbs.nl/nl-nl/nieuws/2021/39/lichte-dalingvarkensstapel-nauwelijks-minder-

runderen\# : : text=Op\%201\%20april\%202021\%20telde,jaren\%20rond\%2 0de\%2012\%20miljoen.\&text=Het $\% 20$ gemiddeld $\% 20$ aantal $\% 20$ varkens $\% 2$ Oper, naar\%203\%20400\%20in\%202021, geraadpleegd op 12 oktober 2021

CLO (2020). Website: https://www.clo.nl/indicatoren/nl0075-voetafdruklandgebruik, geraadpleegd op 6 oktober 2021

Nevedi (2019). Website: Nevedi - Nieuwsbericht, geraadpleegd op 8 december 2021

Nieuwe Oogst (2020). Website:

https://www.nieuweoogst.nl/nieuws/2020/09/25/afrikaanse-roos-vindtweer-weg-naar-veiling, geraadpleegd op 12 oktober 2021

Oorschot, van, M., H. Wilting, D. Nijdam en H. Bredenoord (2021). Halveren van de Nederlandse voetafdruk. Reflectie op een nieuwe ambitie voor het Nederlandse nationale en internationale natuurbeleid. Den Haag: Planbureau voor de Leefomgeving

\section{Hoofdstuk 10 Handel in biologische producten}

EC (Europese Commissie, landbouw).Biologische landbouw, handel https://ec.europa.eu/info/food-farming-fisheries/farming/organicfarming/trade $\mathrm{nl}$ 
FiBL (2021): trade data on organic agriculture in Europe 2005-2019. The Statistics.FiBL.org website maintained by the Research Institute of Organic Agriculture (FiBL), Frick, Switzerland. Available at https://statistics.fibl.org/about.html, October 11, 2021.

https://www.nvwa.nl/onderwerpen/traces/toepassingen-traces

Ruster, Willem, Petra Berkhout, Elisabeth Obeng (2021). Scalable sustainability insights of agri commodity imports, Final deliverable TKI Seed money project 21.25. Wageningen Economic Research, Report 2021-146

-www.skal.n

USDA.gov https://apps.fas.usda.gov/gats/default.aspx

Vries, Iede de (2021). 'Europarlement: biodiversiteit ook meewegen in handelsverdragen', In Nieuwe Oogst, 6 oktober 2021

Willer, Helga, et al. (2021). The World of Organic Agriculture Statistics and Emerging Trends 2021. Research Institute of Organic Agriculture FiBL, Frick, and IFOAM- Organics International, Bonn (v20210301)

\section{Hoofdstuk 11 Handel en internationale welvaart}

Bradford, A. (2020). The Brussels Effect. How the European Union Rules the World. Oxford: Oxford University Press

Centraal Bureau voor de Statistiek (2019). Nederland grootste importeur cacaobonen. July 2019. Retrieved from: https://www.cbs.nl/nlnl/nieuws/2019/31/nederland-grootste-importeur-cacaobonen

Cordes, K., M. Sagan, S. and Kennedy (2021). Responsible Coffee Sourcing: Towards a Living Income for Producers. Retrieved from: https://scholarship.law.columbia.edu/sustainable investment staffpubs/19 9/

Dutch Initiative on Sustainable Cocoa (2020). Dutch Initiative on Sustainable Cocoa. Augustus 2020. Beschikbaar:

https://www.idhsustainabletrade.com/uploaded/2020/06/DISCODeclaration.pdf

EC (European Commission) (2021). Proposal for a Regulation of the European Parliament and of the Council on the making available on the Union market as well as export from the Union of certain commodities and products associated with deforestation and forest degradation and repealing regulation (EU) No 995/2010. November 2021. Retrieved from: https://ec.europa.eu/environment/publications/proposal-regulationdeforestation-free-products en
EP (European Parliament) (2020). Towards a mandatory EU system of due diligence for supply chains. Briefing. October 2020. Retrieved from: https://www.europarl.europa.eu/RegData/etudes/BRIE/2020/659299/EPRS BRI(2020)659299 EN.pdf

EU (European Union) (2021). EU Code of Conduct on Responsible Food Business and Marketing Practices. June 2021. Retrieved from: https://ec.europa.eu/food/system/files/2021-06/f2f sfpd coc final en.pdf

Helpman, E. (2016). Globalization and wage inequality. NBER Working Paper No. 22944. Retrieved from:

https://www.nber.org/system/files/working papers/w22944/w22944.pdf

Logatcheva, K. (2020). Monitor Duurzaam Voedsel 2020. Wageningen Economic Research rapport. https://edepot.wur.nl/551814

OECD (2020). Trade Policy Implications of Global Value Chains. Policy brief. February 2020. Retrieved from: https://www.oecd.org/trade/topics/globalvalue-chains-and-trade/

Oorschot, M. van, J. Brons, J. Janse, T. Rood, E. Vixseboxse, H. Wilting, S. van Berkum (2015). Duurzame handelsketens onder de loep. Achtergronden bij 'Verduurzaming van internationale handelsketens'. Planbureau voor de Leefomgeving. Beschikbaar: https://www.pbl.nl/sites/default/files/downloads/PBL 2015 Duurzame ha ndelsketens onder de loep 1147.pdf

Oya, C., F. Schaefer, D. Skalidou, C. McOsker and L. Langer (2017) Effects of certification schemes for agricultural production on socio-economic outcomes in low- and middle-income countries: a systematic review. Systematic review 34. 3ie International Initiative for Impact Evaluation, London

Rijksoverheid (n.d.). Bevorderen internationaal maatschappelijk verantwoord ondernemen. Beschikbaar op:

https://www.rijksoverheid.nl/onderwerpen/internationaal-maatschappelijkverantwoord-ondernemen-imvo/bevorderen-internationaalmaatschappelijk-verantwoord-ondernemen

Rooij, W. de en M. Slootbeek-van Laar (2020). Monitor Duurzame Cacao 2019. Centraal Bureau voor de Statistiek. Beschikbaar: https://www.cbs.nl/nlnl/achtergrond/2020/23/monitor-duurzame-cacao-2019

Schleifer P., M. Fiorini and L. Fransen (2019). Missing the Bigger Picture: A Population-level Analysis of Transnational Private Governance Organizations Active in the Global South. Ecological Economics. 164. 
Statista (2021). Leading cocoa bean importers worldwide in 2020. June 2021. Retrieved from: https://www.statista.com/statistics/1112363/globalleading-importers-of-cocoa-beans/

Traldi, R. (2021). Progress and pitfalls: A systemic review of the evidence for agricultural sustainability standards. Ecological Indicators. 125.

United Nations (2021). Better Trade for Sustainable development: the role of voluntary sustainability standards. Retrieved from:

https://unctad.org/webflyer/better-trade-sustainable-development-rolevoluntary-sustainability-standards

Waarts, Y., V. Janssen, V. Ingram, M. Slingerland, F. van Rijn and G. Beekman (2019). A living income for smallholder commodity farmers and protected forests and biodiversity: how can the private and public sectors contribute? The Netherlands. Wageningen University \& Research.

Waarts, Y. en M. Kiewisch (2021). Balancing the Living Income Challenge: Towards a multi-actor approach to achieving a living income for cocoa farmers. Wageningen University \& Research and Mondelez International Cocoa Life.

World Trade Organization (2019). Global Value Chain Development Report: Technological Innovation, Supply Chain Trade, and Workers in a Globalized World. Washington DC: World Bank Group. Retrieved from:

https://documents.worldbank.org/en/publication/documentsreports/documentdetail/384161555079173489/global-value-chaindevelopment-report-2019-technological-innovation-supply-chain-tradeand-workers-in-a-globalized-world 


\section{Bijlage 1 Lijst van auteurs}

\section{Hoofdstuk 1 Inleiding}

Petra Berkhout (Wageningen Economic Research)

Hoofdstuk 2 De Nederlandse handel in landbouwgoederen

Pascal Ramaekers (CBS)

Henk van Logtestijn (CBS)

Khee Fung Wong (CBS)

Timon Bohn (CBS)

Hoofdstuk 3 Herkomst en bestemming van Nederlandse handel in landbouwgoederen

Pascal Ramaekers (CBS)

Timon Bohn (CBS)

\section{Hoofdstuk 4 De handel uitgesplitst naar handelsgroepen}

Gerben Jukema (Wageningen Economic Research)

Pascal Ramaekers (CBS)

Timon Bohn (CBS)

Hoofdstuk 5 De handel in landbouwgerelateerde goederen

Pascal Ramaekers (CBS)

Timon Bohn (CBS)

Khee Fung Wong (CBS)

\section{Hoofdstuk 6 De Nederlandse landbouwhandel met het Verenigd}

Koninkrijk 2015-2021

Pascal Ramaekers (CBS)

Janneke Rooyakkers (CBS)

Loe Franssen (CBS)

Sarah Creemers (CBS)
Hoofdstuk 7 De Nederlandse handel in landbouwgoederen en twee jaar coronapandemie

Sarah Creemers (CBS)

Janneke Rooyakkers (CBS)

Pascal Ramaekers (CBS)

\section{Hoofdstuk 8 Handelsbeleid in de landbouw}

Petra Berkhout (Wageningen Economic Research)

Siemen van Berkum (Wageningen Economic Research)

Loe Franssen (CBS)

Hoofdstuk 9 Import naar bestemming

Pascal Ramaekers (CBS)

Khee Fung Wong (CBS)

Hoofdstuk 10 Handel in biologische producten

Gerben Jukema (Wageningen Economic Research)

Hoofdstuk 11 Handel en internationale welvaart Emma Termeer (Wageningen Economic Research)

Yuca Waarts (Wageningen Economic Research) 


\section{Bijlage 2 Dataverantwoording}

\section{B2.1 Raming Nederlandse handel in landbouwgoederen}

Ten tijde van de uitgifte van deze publicatie zijn de definitieve cijfers voor 2021 nog niet voorhanden. Daarom was een raming vereist voor de ontbrekende maanden. Voor de eerst tien maanden is gebruikt gemaakt van gerealiseerde cijfers. Deze worden opgeteld bij een twee-maandenschatting voor november en december. De schatting van deze maanden is gebaseerd op de procentuele ontwikkeling in de eerste tien maanden van 2021 ten opzichte van 2020 en de realisaties in november en december van 2020.

Het CBS levert op verschillende tijdstippen en volgens de voor deze bronnen geëigende definities en voorschriften de Nederlandse cijfers aan aan Eurostat en de Verenigde Naties.

\section{B2.1.1 Definitie in landbouwgoederen}

Wageningen Economic Research heeft samen met het ministerie van Landbouw, Natuur en Voedselkwaliteit (LNV) en het CBS bepaald welke producten wel en niet onder de agrarische sector vallen. Deze lijst is zo veel mogelijk in overeenstemming met de definitie die ook de Europese Commissie (EC) gebruikt voor internationale vergelijkingen. Het verschil met de EC is dat zowel vis- als houtproducten wel opgenomen zijn in de hier gebruikte definitie en deze twee productgroepen door de EC afzonderlijk worden gerapporteerd. De agrarische handel zoals gebruikt in deze publicatie omvat de eerste 24 hoofdstukken van de internationale handelsstatistieken, plus een aantal agrarische producten uit overige hoofdstukken volgens de Gecombineerde Nomenclatuur-coderingssystematiek (GN).

\section{Basisdefinitie landbouwgoederen:}

(01) Levende dieren

(02) Vlees

(03) Vis en zeevruchten

(04) Zuivel en eieren

(05) Andere producten dierlijke oorsprong

(06) Sierteelt

(07) Groenten

(08) Fruit

(09) Koffie, thee, specerijen

(10) Graan

(11) Meel, mout, zetmeel

(12) Oliehoudende zaden en vruchten

(13) Plantensappen

(14) Vlechtstoffen (o.a. bamboe, riet)

(15) Natuurlijke vetten en oliën

(16) Bereidingen van vlees en vis

(17) Suiker en suikerwerk

(18) Cacao en bereidingen

(19) Bereidingen van graan, meel, melk

(20) Bereidingen van groente en fruit

(21) Overige voeding

(22) Dranken

(23) Resten voedselindustrie, veevoer

(24) Tabak en tabaksproducten

+ overige primaire en secundaire landbouwgoederen. Dit zijn de

goederensoorten die starten met de volgende cijfers: 29054500, 3301, $330210,3501,3502,3503,3504,3505,3823,4001,4101,4102,4103,4105$, 4106, 4301, 4302, 4401, 4402, 4403, 4406, 4407, 44081098, 44083930, $4409,4501,4502,5001,5002,5003,5101,5102,5103,5104,5105,5201$, $5203,5301,5302,5303,5304$ en 5305 . 


\section{Landbouwgerelateerde goederen}

De in deze publicatie gebruikte cijfers betreffen de handel in landbouwgoederen. Dit zijn zowel onbewerkte (primaire) als bewerkte (secundaire) goederen. Daarnaast zijn er (niet eetbare) goederen die geproduceerd worden ten behoeve van de landbouwsectoren in binnen- of buitenland, de zogenaamde tertiaire of landbouwgerelateerde goederen. In deze publicatie zijn alleen de producten geselecteerd die direct kunnen worden toegeschreven aan de agrarische sectoren. Het gebruik van drones in de agrarische sector kan bijvoorbeeld momenteel niet inzichtelijk worden gemaakt in de handelscijfers, omdat drones door allerlei sectoren kunnen worden ingezet. Daarom zijn deze niet meegenomen in de in deze uitgave gepubliceerde cijfers. In deze uitgave zijn de volgende landbouwgerelateerde goederen onderscheiden:

Lijst van GN-goederencodes die zijn aangemerkt als landbouwgerelateerde goederen.

\section{Meststoffen}

3808 Gewasbeschermingsmiddelen

8432 Landbouwmachines

8433 Landbouwmachines

8434 Landbouwmachines

8435 Landbouwmachines

8436 Landbouwmachines

84371000 Landbouwmachines

8701 Tractors en landbouwtrailers m.u.v. 87012010 en 87012090

87162000 Tractors en landbouwtrailers

8201 Landbouwgereedschappen

84378000 Machines voor de voedingsmiddelenindustrie 84379000 Machines voor de voedingsmiddelenindustrie 8438 Machines voor de voedingsmiddelenindustrie 84792000 Machines voor de voedingsmiddelenindustrie 30023000 Vaccins voor dieren

84193100 Landbouwdrogers

73089051 Kasmaterialen

73089059 Kasmaterialen

73089098 Kasmaterialen

73089099 Kasmaterialen
94060031 Kasmaterialen 94069031 Kasmaterialen 69099000 Stalinrichting

84248110 Sproeitoestellen 84248210 Sproeitoestellen 84248130 Sproeitoestellen 84248191 Sproeitoestellen 84248199 Sproeitoestellen 84248290 Sproeitoestellen 84244100 Sproeitoestellen 84244910 Sproeitoestellen 84244990 Sproeitoestellen

\section{B2.1.2 Waarom niet overal ook volumes aangeven?}

De gepubliceerde cijfers betreffen vooral waarden. Inzicht in volume is moeilijker te geven omdat er veel verschillende eenheden van een goederensoort zijn die zich moeilijk laten optellen en vergelijken. Veelal worden kilogrammen gebruikt, maar er zijn nog 33 andere eenheden, zoals stuks en liters, die in de handelsstatistieken worden gebruikt. Een ander punt is dat de waardecijfers in de CBS-statistiek Internationale handel in goederen (IHG) traditioneel van hogere kwaliteit zijn dan de hoeveelheidscijfers.

Om toch onderscheid te kunnen maken tussen prijs en volume wordt op de afdeling Nationale Rekeningen (zie begrippenlijst) bij het CBS gebruikgemaakt van betrouwbare meso- en macroramingen. Deze ramingen worden elk kwartaal gemaakt, bijvoorbeeld als onderdeel van de raming van de economische groei in Nederland. Ze geven een nauwkeurig beeld van de volume- en prijsmutaties in de in- en uitvoer van diverse productgroepen, waaronder de landbouwgoederen. De landbouwcijfers zijn echter niet beschikbaar op een laag detailniveau. 


\section{B2.2 Exportverdiensten}

In deze publicatie is daarnaast ook gebruikgemaakt van cijfers over exportverdiensten die het CBS heeft berekend ten aanzien van de bijdrage van de landbouwexport aan het Nederlandse bbp. Hierbij wordt gebruikgemaakt van waardeketenanalyse. Een internationale waardeketen omvat alle activiteiten - in meer dan één land - die nodig zijn om een product of dienst vanuit de conceptfase via de verschillende productiefases bij eindgebruikers te bezorgen en voor de verwerking na gebruik. Waardeketenanalyse wordt gedaan op basis van input-outputtabellen (zie begrippenlijst) van de Nationale Rekeningen van het CBS. 


\section{Bijlage 3 Begrippenlijst}

\section{B3.1 Handel}

\section{Uitvoerwaarde (export)}

De waarde van de door ingezetenen aan het buitenland geleverde goederen volgens de statistieken van de internationale handel. Dit is de waarde, inclusief vracht- en verzekeringskosten, tot aan de Nederlandse grens. Dit kunnen goederen zijn die in Nederland zijn voortgebracht of vervaardigd, maar ook aanvankelijk ingevoerde goederen. Tot de uitvoer behoren ook tijdelijk uitgevoerde goederen die in opdracht van een ingezetene in het buitenland een behandeling ondergaan (passieve loonveredeling).

\section{Quasi-doorvoer}

Quasi-doorvoer betreft invoer van goederen van buitenlandse makelij die na aankomst in Nederland niet of nauwelijks een bewerking ondergaan en daarna weer worden doorgevoerd naar het buitenland. De goederen zijn tijdens het gehele verblijf in Nederland eigendom van een buitenlands bedrijf (in tegenstelling tot bij wederuitvoer). De quasi-doorvoer is geen onderdeel van de Nederlandse cijfers over de Nederlandse handel (bron: CBS), wel bij de Europese cijfers over de Nederlandse handel (bron: Eurostat).

\section{Uitvoer van goederen van Nederlandse makelij}

Uitvoer van goederen van Nederlandse makelij betreft uitvoer na productie in Nederland of uitvoer na significante bewerking van goederen van buitenlandse makelij (waarbij wordt gekeken in hoeverre de statistische goederencode van het goed al dan niet sterk is veranderd). Wederuitvoer en uitvoer van goederen van Nederlandse makelij vormen samen de totale Nederlandse uitvoercijfers. Significante bewerking betreft een verandering in de eerste zes digits van de GN-goederencode.

\section{Wederuitvoer}

Wederuitvoer betreft invoer van goederen van buitenlandse makelij die na aankomst in Nederland niet of nauwelijks een bewerking ondergaan en daarna weer worden doorgevoerd naar het buitenland. De goederen zijn tijdens het verblijf in Nederland (tijdelijk) eigendom van een Nederlands bedrijf (in tegenstelling tot bij quasi-doorvoer). Lichte bewerking betreft een verandering in de zevende en/of achtste digit van de GN-goederencode, maar het kan ook gaan om een handeling zonder verandering van de goederencode (zoals het rijpen en sorteren van avocado's of het maken van boeketten van geïmporteerde bloemen).

\section{Invoerwaarde (import)}

De waarde van door het buitenland aan ingezetenen geleverde goederen volgens de statistieken van de internationale handel. Bij invoer uit EU-landen is dit de waarde van de goederen, inclusief vracht- en verzekeringskosten, tot aan de Nederlandse grens. Bij invoer uit niet-EU-landen is dit de waarde, inclusief vracht- en verzekeringskosten, tot aan de buitengrens van de Europese Unie.

De invoer van goederen betreft alle goederen die voor gebruik of verbruik in het economisch vrije verkeer van Nederland zijn gebracht. Dit is het geval wanneer de invoerheffingen en nationale belastingen zijn voldaan. Tot de invoer van goederen behoren ook:

- tijdelijk ingevoerde goederen die in ons land, in opdracht van een nietingezetene, een behandeling ondergaan (actieve loonveredeling);

- goederen uit niet-EU-landen die via een entrepot in het economisch vrije verkeer van Nederland komen;

- ingevoerde goederen die, zonder enige bewerking te hebben ondergaan, weer worden uitgevoerd (wederuitvoer). 


\section{Handelsbalans}

De handelsbalans geeft het saldo aan tussen uitvoerwaarde en invoerwaarde, beide gemeten in euro. Meer uitvoer dan invoer geeft een handelsoverschot, omgekeerd wordt gesproken van een handelstekort.

\section{B3.2 Exportverdiensten}

\section{Bruto binnenlands product (bbp)}

Een maat voor de omvang van de economie. Deze wordt berekend uit de som van de waarde die door ondernemingen, huishoudens en overheden wordt toegevoegd aan de goederen en diensten die zij hebben moeten verbruiken om hun producten te kunnen maken. Deze som staat bekend als de toegevoegde waarde 'in basisprijzen'. Om tot het bbp 'in marktprijzen' te komen, wordt hierbij het saldo van productgebonden belastingen en subsidies én het verschil tussen toegerekende en afgedragen btw opgeteld.

\section{Input-outputanalyse}

Met input-outputanalyse worden onder andere de uitgaven aan primaire inputs en productiefactoren, zoals de kosten van goederen en diensten die niet in Nederland zijn geproduceerd (import), en de productiefactoren (arbeid, kapitaal, ondernemerschap) toegerekend aan de finale bestedingen

(consumptie door huishoudens, consumptie door overheid, investeringen, export). Met de input-outputanalyse worden daarnaast indirecte intermediaire leveringen tussen bedrijfstakken in beeld gebracht, waardoor afhankelijkheden in waardeketens zichtbaar kunnen worden gemaakt. 


\section{Bijlage 4 Uitgebreide tabellen van de landbouwgoederenhandel naar productgroepen en landen}

Tabel B4.1 Import van landbouw- en landbouwgerelateerde goederen (mrd. euro)

\begin{tabular}{llcl} 
& & $\mathbf{2 0 2 0}$ & $\mathbf{2 0 2 1}$ (raming) \\
Alle landbouwgoederen & $\mathbf{6 5 , 9}$ & $\mathbf{7 2 , 5}$ \\
\hline naar goederengroep (2 digit GN code) & & \\
\hline GN-15 & Natuurlijke vetten en olien & 5,9 & $\mathbf{7 , 1}$ \\
\hline GN-08 & Fruit & 7,2 & 7,1 \\
\hline GN-X. & Overige primaire en secundaire landbouw & 4,3 & 5,6 \\
\hline GN-22 & Dranken & 4,5 & 5,0 \\
\hline GN-12 & Oliehoudende zaden en vruchten & 4,4 & 4,9 \\
\hline GN-04 & Zuivel en eieren & 4,0 & 4,3 \\
\hline GN-18 & Cacao en -bereidingen & 3,7 & 4,1 \\
\hline GN-02 & Vlees & 3,6 & 3,7 \\
\hline GN-23 & Resten van de voedselindustrie, veevoer & 3,2 & 3,5 \\
\hline GN-10 & Graan & 2,8 & 3,3 \\
\hline GN-21 & Overige voeding & 2,7 & 3,1 \\
\hline GN-07 & Groenten & 2,5 & 2,8 \\
\hline GN-20 & Bereidingen van groente en fruit & 2,7 & 2,7 \\
\hline GN-06 & Sierteelt & 2,2 & 2,7 \\
\hline GN-19 & Bereidingen van graan, meel en melk & 2,4 & 2,6 \\
\hline GN-03 & Vis en zeevruchten & 2,1 & 2,3 \\
\hline GN-16 & Bereidingen van vlees en vis & 1,8 & 1,8 \\
\hline GN-09 & Koffie, thee, specerijen & 1,5 & 1,6 \\
\hline GN-01 & Levende dieren & 1,1 & 1,2 \\
\hline GN-17 & Suiker en suikerwerk & 0,9 & 0,9 \\
\hline GN-11 & Meel, mout en zetmeel & 0,8 & 0,8 \\
\hline GN-24 & Tabak en tabaksproducten & 0,8 & 0,7 \\
\hline GN-05 & Andere producten dierlijke oorsprong & 0,4 & 0,4 \\
\hline & & &
\end{tabular}

\begin{tabular}{lrr} 
& $\mathbf{2 0 2 0}$ & $\mathbf{2 0 2 1}$ (raming) \\
GN-13 & 0,2 & 0,2 \\
\hline GN-14 Vlantensappen & 0,1 & 0,1 \\
\hline \multicolumn{2}{l}{ Vlechtstoffen (o.a. bamboe, riet) } & \\
\hline Totaal landbouw en landbouw gerelateerde goederen & $\mathbf{4 , 6}$ & $\mathbf{5 , 3}$ \\
\hline$\quad$ Naar goederengroep & & \\
\hline Landbouwmachines & 1,1 & 1,4 \\
\hline Kasmaterialen & 1,0 & 1,1 \\
\hline Meststoffen & 0,6 & 0,8 \\
\hline Gewasbeschermingsmiddelen & 0,6 & 0,7 \\
\hline Machines voor de voedingsmiddelenindustrie & 0,5 & 0,5 \\
\hline Tractors en landbouwtrailers & 0,5 & 0,5 \\
\hline Vaccins voor dieren & 0,2 & 0,1 \\
\hline Landbouwgereedschappen & 0,1 & 0,1 \\
\hline Sproeitoestellen & 0,1 & 0,1 \\
\hline Stalinrichting & 0,0 & 0,0 \\
\hline Droogtoestellen voor landbouwproducten & 0,0 & 0,0 \\
\hline
\end{tabular}

Totaal landbouw en landbouw gerelateerde goederen $\quad \mathbf{7 0 , 5}$ 77,8 
Tabel B4.2 Export van landbouw- en landbouwgerelateerde goederen (mrd. euro)

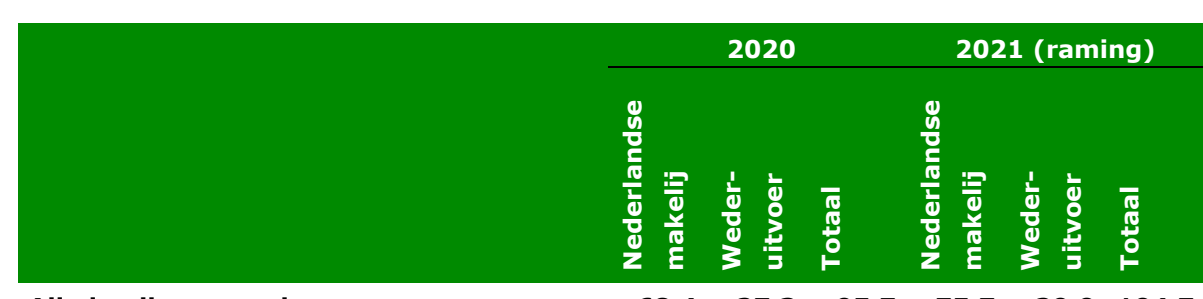

Alle landbouwgoederen

$\begin{array}{llllll}68,4 & 27,3 & 95,7 & 75,7 & 29,0 & 104,7\end{array}$

naar goederengroep (2 digits GN code)

\begin{tabular}{llrrrrrr}
\hline GN-06 & Sierteelt & 8,5 & 1,0 & 9,6 & 10,5 & 1,5 & 12,0 \\
\hline GN-02 & Vlees & 7,5 & 1,0 & 8,5 & 8,1 & 1,0 & 9,1 \\
\hline GN-04 & Zuivel en eieren & 6,7 & 1,6 & 8,3 & 7,1 & 1,7 & 8,7 \\
\hline GN-07 & Groenten & 5,8 & 1,3 & 7,0 & 5,8 & 1,3 & 7,2 \\
\hline GN-08 & Fruit & 1,5 & 5,5 & 7,0 & 1,7 & 5,3 & 7,0 \\
\hline GN-22 & Dranken & 4,3 & 1,7 & 6,0 & 4,5 & 2,1 & 6,6 \\
\hline GN-15 & Natuurlijke vetten en olien & 2,8 & 1,9 & 4,7 & 4,0 & 1,7 & 5,7 \\
\hline GN-21 & Overige voeding & 3,4 & 1,6 & 5,0 & 3,8 & 1,7 & 5,5 \\
\hline GN-23 & Resten van de voedselindustrie, & 3,5 & 1,4 & 5,0 & 3,9 & 1,5 & 5,4 \\
& veevoer & & & & & & \\
\hline GN-19 & Bereidingen van graan, meel en & 4,5 & 0,8 & 5,3 & 4,1 & 0,9 & 5,0 \\
& melk & & & & & & \\
\hline GN-20 & Bereidingen van groente en fruit & 3,4 & 1,5 & 4,9 & 3,9 & 1,4 & 5,3 \\
\hline GN-X. & Overige primaire en secundaire & 3,1 & 1,0 & 4,1 & 4,1 & 1,4 & 5,5 \\
& landbouw & & & & & & \\
\hline GN-18 & Cacao en -bereidingen & 3,0 & 1,4 & 4,4 & 3,2 & 1,6 & 4,8 \\
\hline GN-12 & Oliehoudende zaden en vruchten & 1,9 & 1,9 & 3,8 & 2,1 & 2,0 & 4,0 \\
\hline GN-03 & Vis en zeevruchten & 2,2 & 0,8 & 3,0 & 2,4 & 0,9 & 3,3 \\
\hline GN-16 & Bereidingen van vlees en vis & 1,2 & 0,6 & 1,8 & 1,2 & 0,7 & 2,0 \\
\hline GN-01 & Levende dieren & 1,5 & 0,2 & 1,8 & 1,4 & 0,3 & 1,7 \\
\hline GN-17 & Suiker en suikerwerk & 1,1 & 0,4 & 1,5 & 1,3 & 0,3 & 1,7 \\
\hline GN-09 & Koffie, thee, specerijen & 0,6 & 0,6 & 1,2 & 0,7 & 0,6 & 1,3 \\
\hline GN-24 & Tabak en tabaksproducten & 0,7 & 0,3 & 1,0 & 0,6 & 0,3 & 0,9 \\
\hline GN-11 & Meel, mout en zetmeel & 0,7 & 0,1 & 0,8 & 0,8 & 0,1 & 0,9 \\
\hline GN-05 & Andere producten dierlijke & 0,2 & 0,4 & 0,6 & 0,2 & 0,4 & 0,6 \\
& oorsprong & 0,2 & 0,4 & 0,6 & 0,2 & 0,3 & 0,5 \\
\hline GN-10 & Graan & 0,1 & 0,0 & 0,1 & 0,1 & 0,0 & 0,1 \\
\hline GN-13 & Plantensappen & 0,0 & 0,0 & 0,0 & 0,0 & 0,0 & 0,0 \\
\hline GN-14 & Vlechtstoffen (o.a. bamboe, riet) & & & & & \\
\hline & & & & & & \\
\hline
\end{tabular}

Alle landbouwgerelateerde goederen

naar goederengroep

\begin{tabular}{lllllll}
\hline & 2,0 & 0,5 & 2,5 & 2,1 & 0,6 & 2,7 \\
\hline Landbouwmachines & 1,5 & 0,3 & 1,8 & 1,9 & 0,3 & 2,2 \\
\hline $\begin{array}{l}\text { Meststoffen } \\
\text { vachines voor de }\end{array}$ & 1,7 & 0,2 & 1,8 & 1,8 & 0,2 & 1,9 \\
\hline Kasmaterialen & 1,4 & 0,2 & 1,6 & 1,4 & 0,3 & 1,6 \\
\hline Vaccins voor dieren & 0,0 & 0,7 & 0,7 & 0,0 & 0,9 & 0,9 \\
\hline Gewasbeschermingsmiddelen & 0,4 & 0,2 & 0,5 & 0,4 & 0,2 & 0,6 \\
\hline Tractors en landbouwtrailers & 0,2 & 0,1 & 0,3 & 0,2 & 0,1 & 0,3 \\
\hline Sproeitoestellen & 0,2 & 0,0 & 0,2 & 0,2 & 0,0 & 0,2 \\
\hline Landbouwgereedschappen & 0,0 & 0,1 & 0,1 & 0,0 & 0,1 & 0,1 \\
\hline $\begin{array}{l}\text { Droogtoestellen voor } \\
\text { landbouwproducten }\end{array}$ & 0,0 & 0,0 & 0,0 & 0,0 & 0,0 & 0,0 \\
\hline Stalinrichting & 0,0 & 0,0 & 0,0 & 0,0 & 0,0 & 0,0
\end{tabular}

Totale landbouw en

$\begin{array}{llllll}75,7 & 29,6 & 105,3 & 83,7 & 31,6 & 115,3\end{array}$

landbouwgerelateerde goederen 
Tabel B4.3 Import van landbouwgoederen naar herkomstland (mrd. euro).[1]

\begin{tabular}{|c|c|c|}
\hline & 2020 & 2021 (raming) \\
\hline Totaal landen & 65,9 & 72,5 \\
\hline EU-27 & 29,2 & 31,0 \\
\hline Niet EU & 36,7 & 41,4 \\
\hline \multicolumn{3}{|l|}{ Naar herkomstland } \\
\hline Duitsland & 11,5 & 13,0 \\
\hline België & 8,9 & 9,5 \\
\hline Overig niet-EU & 4,3 & 5,1 \\
\hline Frankrijk & 4,1 & 4,5 \\
\hline Brazilië & 2,8 & 3,3 \\
\hline Spanje & 2,7 & 2,9 \\
\hline VS & 2,5 & 2,4 \\
\hline Polen & 1,8 & 2,1 \\
\hline Italië & 1,8 & 2,1 \\
\hline Verenigd Koninkrijk & 2,3 & 1,8 \\
\hline Oekraïne & 1,5 & 1,7 \\
\hline Indonesië & 1,3 & 1,6 \\
\hline Overig EU & 1,2 & 1,4 \\
\hline Maleisië & 1,1 & 1,4 \\
\hline Ierland & 1,1 & 1,3 \\
\hline China & 1,3 & 1,3 \\
\hline Peru & 1,1 & 1,2 \\
\hline Ivoorkust & 1,2 & 1,2 \\
\hline Zuid-Afrika & 1,0 & 1,1 \\
\hline Denemarken & 0,9 & 1,0 \\
\hline Argentinië & 0,9 & 0,9 \\
\hline Zweden & 0,5 & 0,8 \\
\hline India & 0,6 & 0,7 \\
\hline Chili & 0,7 & 0,6 \\
\hline Oostenrijk & 0,5 & 0,6 \\
\hline Turkije & 0,6 & 0,6 \\
\hline Thailand & 0,5 & 0,5 \\
\hline Kenia & 0,5 & 0,5 \\
\hline Australië & 0,4 & 0,5 \\
\hline Roemenië & 0,4 & 0,5 \\
\hline Ecuador & 0,4 & 0,5 \\
\hline Vietnam & 0,5 & 0,5 \\
\hline Costa Rica & 0,5 & 0,5 \\
\hline
\end{tabular}

\begin{tabular}{lll} 
Colombia & 0,4 & 0,5 \\
\hline Canada & 0,6 & 0,4 \\
\hline Marokko & 0,4 & 0,4 \\
\hline Portugal & 0,3 & 0,4 \\
\hline Hongarije & 0,3 & 0,3 \\
\hline Nieuw-Zeeland & 0,3 & 0,3 \\
\hline Rusland & 0,2 & 0,3 \\
\hline Tsjechië & 0,2 & 0,3 \\
\hline Griekenland & 0,2 & 0,2 \\
\hline Noorwegen & 0,2 & 0,2 \\
\hline Mexico & 0,2 & 0,2 \\
\hline Finland & 0,1 & 0,2 \\
\hline Israël & 0,2 & 0,2 \\
\hline Japan & 0,1 & 0,2 \\
\hline Ethiopië & 0,1 & 0,1 \\
\hline Slowakije & 0,1 & 0,1 \\
\hline Zwitserland & 0,1 & 0,1 \\
\hline Oeganda & 0,1 & 0,1 \\
\hline Zuid-Korea & 0,1 & 0,1 \\
\hline Taiwan & 0,0 & 0,1 \\
\hline Saoedi-Arabië & 0,0 & 0,1 \\
\hline Senegal & 0,0 & 0,0 \\
\hline Tunesië & 0,0 & 0,0 \\
\hline Kroatië & 0,0 & 0,0 \\
\hline Verenigde Arabische Emiraten & 0,0 & 0,0 \\
\hline Angola & 0,0 & 0,0 \\
\hline IJ & 00 &
\end{tabular}

[1] De landenlijst in B4.3 en B.4.6 zijn een selectie van landen en is daarom niet compleet. 
Tabel B4.4 Import van landbouw- en landbouwgerelateerde goederen naar herkomstland (mrd. euro)

\begin{tabular}{|c|c|c|}
\hline & 2020 & 2021 (raming) \\
\hline Totaal landen & 70,5 & 77,8 \\
\hline EU-27 & 32,8 & 35,1 \\
\hline Niet EU & 37,8 & 42,7 \\
\hline \multicolumn{3}{|l|}{ Naar herkomstland } \\
\hline Duitsland & 12,6 & 14,3 \\
\hline België & 9,9 & 10,6 \\
\hline Overig niet-EU & 4,4 & 5,1 \\
\hline Frankrijk & 4,3 & 4,8 \\
\hline Brazilië & 2,8 & 3,3 \\
\hline Spanje & 2,8 & 3,1 \\
\hline VS & 2,8 & 2,7 \\
\hline Polen & 2,0 & 2,4 \\
\hline Italië & 2,0 & 2,3 \\
\hline Verenigd Koninkrijk & 2,6 & 2,0 \\
\hline Oekraïne & 1,5 & 1,7 \\
\hline Indonesië & 1,3 & 1,6 \\
\hline China & 1,5 & 1,6 \\
\hline Overig EU & 1,3 & 1,5 \\
\hline Maleisië & 1,1 & 1,4 \\
\hline Ierland & 1,1 & 1,3 \\
\hline Peru & 1,1 & 1,2 \\
\hline Ivoorkust & 1,2 & 1,2 \\
\hline Denemarken & 1,1 & 1,1 \\
\hline Zuid-Afrika & 1,0 & 1,1 \\
\hline Zweden & 0,6 & 0,9 \\
\hline Argentinië & 0,9 & 0,9 \\
\hline India & 0,6 & 0,7 \\
\hline Oostenrijk & 0,6 & 0,7 \\
\hline Chili & 0,7 & 0,6 \\
\hline Turkije & 0,6 & 0,6 \\
\hline Australië & 0,4 & 0,6 \\
\hline Roemenië & 0,4 & 0,5 \\
\hline Thailand & 0,5 & 0,5 \\
\hline Kenia & 0,5 & 0,5 \\
\hline Ecuador & 0,4 & 0,5 \\
\hline Vietnam & 0,5 & 0,5 \\
\hline
\end{tabular}

Colombia

Canada

Hongarije

0,5

$\begin{array}{lll}2,3 & 0,4\end{array}$

\begin{tabular}{lll} 
Portugal & 0,4 & 0,4 \\
\hline Marokko
\end{tabular}

\begin{tabular}{lll} 
Marokko & 0,4 & 0,4 \\
\hline
\end{tabular}

Rusland

0,4

\begin{tabular}{lcc} 
Nieuw-Zeeland & 0,3 & 0,4 \\
\hline
\end{tabular}

Tsjechië $\quad 0,3 \quad 0,3$

Finland $0,2 \quad 0,3$

\begin{tabular}{lll} 
Israël & 0,3 & 0,3 \\
\hline
\end{tabular}

\begin{tabular}{lll} 
Griekenland & 0,2 & 0,2 \\
\hline
\end{tabular}

Noorwegen $\quad 0,2 \quad 0,2$

Mexico $0,2 \quad 0,2$

\begin{tabular}{lll}
\hline Japan & 0,2 & 0,2 \\
\hline
\end{tabular}

Slowakije $\quad 0,1 \quad 0,1$

Zwitserland $\quad 0,1 \quad 0,1$

Ethiopië $\quad 0,1 \quad 0,1$

Oeganda $\quad 0,1 \quad 0,1$

$\begin{array}{lll}\text { Zuid-Korea } & 0,1 & 0,1\end{array}$

Taiwan $\quad 0,1 \quad 0,1$

Saoedi-Arabië $\quad 0,0 \quad 0,1$

Kroatië $\quad 0,0 \quad 0,0$

Senegal $\quad 0,0 \quad 0,0$

Tunesië $\quad 0,0 \quad 0,0$

\begin{tabular}{lll} 
Verenigde Arabische Emiraten & 0,0 & 0,0 \\
\hline
\end{tabular}

Angola 
Tabel B4.5 Export van landbouwgoederen naar bestemming (mrd. euro)

\begin{tabular}{|c|c|c|c|c|c|c|}
\hline & \multicolumn{3}{|c|}{2020} & \multicolumn{3}{|c|}{2021 (raming) } \\
\hline & 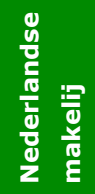 & 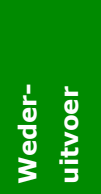 & 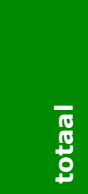 & 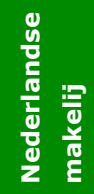 & $\begin{array}{l}\frac{1}{5} \\
\frac{1}{0} \\
\vdots \\
\vdots \\
\vdots\end{array}$ & $\begin{array}{l}\text { 흄 } \\
\text { ㅎํ }\end{array}$ \\
\hline Totaal landen & 68,4 & 27,3 & 95,7 & 75,7 & 29,0 & 104,7 \\
\hline EU-27 & 42,1 & 22,0 & 64,1 & 48,1 & 24,1 & 72,3 \\
\hline Niet EU & 26,3 & 5,3 & 31,6 & 27,6 & 4,8 & 32,4 \\
\hline Duitsland & 15,9 & 8,6 & 24,5 & 17,3 & 9,0 & 26,3 \\
\hline België & 6,9 & 3,8 & 10,7 & 8,0 & 4,1 & 12,1 \\
\hline Frankrijk & 4,9 & 2,6 & 7,6 & 5,7 & 2,9 & 8,6 \\
\hline Verenigd Koninkrijk & 6,1 & 2,4 & 8,5 & 7,0 & 1,6 & 8,6 \\
\hline Overig niet-EU & 4,9 & 0,6 & 5,5 & 4,6 & 0,7 & 5,4 \\
\hline Italië & 2,6 & 0,7 & 3,3 & 3,0 & 0,9 & 3,9 \\
\hline China & 3,6 & 0,2 & 3,8 & 3,6 & 0,3 & 3,9 \\
\hline Spanje & 1,9 & 0,9 & 2,7 & 2,2 & 1,1 & 3,3 \\
\hline Polen & 1,7 & 1,0 & 2,7 & 2,1 & 1,1 & 3,3 \\
\hline VS & 2,5 & 0,3 & 2,7 & 2,7 & 0,3 & 3,0 \\
\hline Denemarken & 1,3 & 0,6 & 1,9 & 1,6 & 0,7 & 2,3 \\
\hline Zweden & 1,3 & 0,6 & 2,0 & 1,5 & 0,7 & 2,2 \\
\hline Overig EU & 0,9 & 0,5 & 1,4 & 1,3 & 0,7 & 1,9 \\
\hline Ierland & 0,8 & 0,3 & 1,1 & 1,0 & 0,4 & 1,4 \\
\hline Zwitserland & 1,0 & 0,3 & 1,2 & 1,0 & 0,3 & 1,3 \\
\hline Oostenrijk & 0,7 & 0,5 & 1,2 & 0,8 & 0,5 & 1,3 \\
\hline Finland & 0,5 & 0,5 & 1,0 & 0,5 & 0,6 & 1,1 \\
\hline Noorwegen & 0,8 & 0,3 & 1,1 & 0,8 & 0,3 & 1,1 \\
\hline Tsjechië & 0,6 & 0,3 & 1,0 & 0,7 & 0,3 & 1,1 \\
\hline Rusland & 0,9 & 0,2 & 1,0 & 0,8 & 0,2 & 1,0 \\
\hline Griekenland & 0,6 & 0,2 & 0,8 & 0,6 & 0,2 & 0,8 \\
\hline Japan & 0,7 & 0,1 & 0,8 & 0,7 & 0,1 & 0,8 \\
\hline Roemenië & 0,4 & 0,2 & 0,6 & 0,4 & 0,3 & 0,7 \\
\hline Zuid-Korea & 0,4 & 0,0 & 0,5 & 0,6 & 0,0 & 0,6 \\
\hline Portugal & 0,3 & 0,2 & 0,5 & 0,4 & 0,2 & 0,6 \\
\hline Hongarije & 0,3 & 0,2 & 0,5 & 0,4 & 0,2 & 0,6 \\
\hline Turkije & 0,4 & 0,1 & 0,6 & 0,4 & 0,1 & 0,6 \\
\hline Saoedi-Arabië & 0,5 & 0,1 & 0,5 & 0,5 & 0,1 & 0,6 \\
\hline
\end{tabular}

Australië

Verenigde Arabische Emiraten

Canada

Mexico

Oekraïne

Slowakije

Zuid-Afrika

Israë

Taiwan

Kroatië

Marokko

Brazilië

Maleisië

Indonesië

Vietnam

Thailand

Chili

Nieuw-Zeeland

Ivoorkust

India

Colombia

Senegal

Peru

Costa Rica

Argentinië

Oeganda

Ecuador

Kenia

Tunesië

Angola

Ethiopië

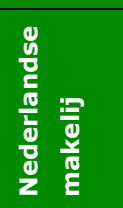

0,5 0,4 $\begin{array}{llll}0,5 & 0,5 & 0,1 & 0,5\end{array}$ $\begin{array}{llllll}0,3 & 0,0 & 0,3 & 0,4 & 0,0 & 0,4\end{array}$ $\begin{array}{llllll}0,3 & 0,0 & 0,3 & 0,4 & 0,0 & 0,4\end{array}$ $\begin{array}{llllll}0,3 & 0,1 & 0,3 & 0,3 & 0,1 & 0,4\end{array}$ $\begin{array}{llllll}0,2 & 0,1 & 0,3 & 0,2 & 0,1 & 0,4\end{array}$ $\begin{array}{llllll}0,2 & 0,0 & 0,3 & 0,3 & 0,0 & 0,3\end{array}$ $\begin{array}{llllll}0,3 & 0,0 & 0,3 & 0,3 & 0,0 & 0,3\end{array}$

$\begin{array}{llllll}0,2 & 0,0 & 0,2 & 0,3 & 0,0 & 0,3\end{array}$

$\begin{array}{llllll}0,2 & 0,1 & 0,2 & 0,2 & 0,1 & 0,3 \\ 0,3 & 0,0 & 0,3 & 0,3 & 0,0 & 0,3\end{array}$

$\begin{array}{llllll}0,2 & 0,1 & 0,2 & 0,2 & 0,1 & 0,3 \\ 0,3 & 0,0 & 0,3 & 0,3 & 0,0 & 0,3\end{array}$

\begin{tabular}{llllll}
0,2 & 0,0 & 0,3 & 0,2 & 0,0 & 0,3 \\
\hline, 2 & 0,0 & 0,2 & 0,2 & 0,0 & 0,2
\end{tabular}

$\begin{array}{llllll}0,2 & 0,0 & 0,2 & 0,2 & 0,0 & 0,2\end{array}$

$\begin{array}{llllll}0,2 & 0,0 & 0,2 & 0,2 & 0,0 & 0,2\end{array}$

$\begin{array}{llllll}0,2 & 0,0 & 0,2 & 0,2 & 0,0 & 0,2 \\ 0,1 & 0,0 & 0,2 & 0,1 & 0,0 & 0,2\end{array}$

$\begin{array}{llllll}0,1 & 0,0 & 0,2 & 0,1 & 0,0 & 0,2\end{array}$

$\begin{array}{llllll}0,1 & 0,0 & 0,1 & 0,2 & 0,0 & 0,2\end{array}$

$\begin{array}{llllll}0,1 & 0,0 & 0,1 & 0,1 & 0,0 & 0,1 \\ 0,1 & 0,0 & 0,1 & 0,1 & 0,0 & 0,1\end{array}$

\begin{tabular}{llllll}
0,1 & 0,0 & 0,1 & 0,1 & 0,0 & 0,1 \\
\hline
\end{tabular}

$\begin{array}{llllll}0,1 & 0,0 & 0,1 & 0,1 & 0,0 & 0,1 \\ 0,1 & 0,0 & 0,1 & 0,1 & 0,0 & 0,1\end{array}$

$\begin{array}{llllll}0,1 & 0,0 & 0,1 & 0,1 & 0,0 & 0,1\end{array}$

\begin{tabular}{llllll}
0,1 & 0,0 & 0,1 & 0,1 & 0,0 & 0,1 \\
\hline
\end{tabular}

$\begin{array}{llllll}0,1 & 0,0 & 0,1 & 0,1 & 0,0 & 0,1\end{array}$

$\begin{array}{llllll}0,0 & 0,0 & 0,0 & 0,0 & 0,0 & 0,0 \\ 0,0 & 0,0 & 0,0 & 0,0 & 0,0 & 0,0\end{array}$

$\begin{array}{llllll}0,0 & 0,0 & 0,0 & 0,0 & 0,0 & 0,0\end{array}$

$\begin{array}{llllll}0,0 & 0,0 & 0,0 & 0,0 & 0,0 & 0,0\end{array}$

$\begin{array}{llllll}0,0 & 0,0 & 0,0 & 0,0 & 0,0 & 0,0\end{array}$

$\begin{array}{llllll}0,0 & 0,0 & 0,0 & 0,0 & 0,0 & 0,0 \\ 0,0 & 0,0 & 0,0 & 0,0 & 0,0 & 0,0\end{array}$

$\begin{array}{llllll}0,0 & 0,0 & 0,0 & 0,0 & 0,0 & 0,0\end{array}$

\begin{tabular}{llllll}
0,0 & 0,0 & 0,0 & 0,0 & 0,0 & 0,0 \\
\hline 0,0 & 0,0 & 0,0 & 0,0 & 0,0 & 0,0
\end{tabular}

114 | Wageningen Economic Research Rapport 2022-001 
Tabel B4.6 Export van landbouw- en landbouwgerelateerde goederen naar bestemming (mrd. euro)

\begin{tabular}{|c|c|c|c|c|c|c|}
\hline & \multicolumn{3}{|c|}{2020} & \multicolumn{3}{|c|}{2021 (raming) } \\
\hline & 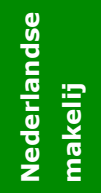 & 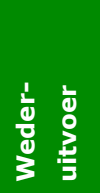 & 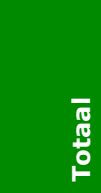 & 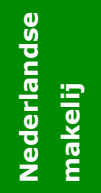 & $\begin{array}{ll}\frac{1}{d} \\
\frac{1}{d} \\
\frac{d}{3} \\
\frac{3}{3}\end{array}$ & . \\
\hline Totaal landen & 75,7 & 29,6 & 105,3 & 83,7 & 31,6 & 115,3 \\
\hline EU-27 & 45,7 & 23,5 & 69,1 & 52,3 & 25,9 & 78,2 \\
\hline Niet EU & 30,1 & 6,1 & 36,2 & 31,3 & 5,7 & 37,1 \\
\hline Duitsland & 16,9 & 9,0 & 25,9 & 18,4 & 9,5 & 27,8 \\
\hline België & 7,5 & 4,1 & 11,7 & 8,8 & 4,5 & 13,3 \\
\hline Frankrijk & 5,6 & 2,8 & 8,4 & 6,6 & 3,1 & 9,8 \\
\hline Verenigd Koninkrijk & 6,7 & 2,6 & 9,3 & 7,4 & 1,7 & 9,1 \\
\hline Overig niet-EU & 5,3 & 0,8 & 6,1 & 5,0 & 0,8 & 5,8 \\
\hline China & 3,9 & 0,2 & 4,1 & 3,8 & 0,4 & 4,2 \\
\hline Italië & 2,7 & 0,8 & 3,5 & 3,2 & 1,0 & 4,1 \\
\hline VS & 3,0 & 0,3 & 3,3 & 3,3 & 0,4 & 3,7 \\
\hline Spanje & 2,0 & 1,0 & 3,0 & 2,4 & 1,2 & 3,6 \\
\hline Polen & 1,9 & 1,1 & 3,0 & 2,4 & 1,2 & 3,6 \\
\hline Denemarken & 1,4 & 0,7 & 2,1 & 1,7 & 0,8 & 2,5 \\
\hline Zweden & 1,4 & 0,7 & 2,1 & 1,6 & 0,7 & 2,3 \\
\hline Overig EU & 1,0 & 0,6 & 1,6 & 1,4 & 0,7 & 2,2 \\
\hline Ierland & 0,8 & 0,4 & 1,2 & 1,0 & 0,5 & 1,5 \\
\hline Oostenrijk & 0,8 & 0,5 & 1,3 & 0,9 & 0,5 & 1,5 \\
\hline Zwitserland & 1,1 & 0,3 & 1,3 & 1,1 & 0,3 & 1,4 \\
\hline Rusland & 1,1 & 0,2 & 1,4 & 1,0 & 0,2 & 1,2 \\
\hline Noorwegen & 0,9 & 0,3 & 1,2 & 0,8 & 0,4 & 1,2 \\
\hline Finland & 0,5 & 0,5 & 1,1 & 0,6 & 0,6 & 1,2 \\
\hline Tsjechië & 0,7 & 0,3 & 1,0 & 0,8 & 0,4 & 1,1 \\
\hline Japan & 0,9 & 0,1 & 0,9 & 0,8 & 0,1 & 0,9 \\
\hline Griekenland & 0,7 & 0,2 & 0,9 & 0,7 & 0,2 & 0,9 \\
\hline Roemenië & 0,5 & 0,3 & 0,7 & 0,5 & 0,3 & 0,8 \\
\hline Australië & 0,6 & 0,1 & 0,7 & 0,6 & 0,1 & 0,7 \\
\hline Saoedi-Arabië & 0,5 & 0,1 & 0,6 & 0,6 & 0,1 & 0,7 \\
\hline Hongarije & 0,4 & 0,2 & 0,6 & 0,5 & 0,2 & 0,7 \\
\hline
\end{tabular}

\begin{tabular}{lllllll} 
Zuid-Korea & 0,5 & 0,1 & 0,5 & 0,6 & 0,1 & 0,7 \\
\hline Portugal & 0,4 & 0,2 & 0,6 & 0,4 & 0,2 & 0,7 \\
\hline Canada & 0,6 & 0,0 & 0,6 & 0,6 & 0,0 & 0,7 \\
\hline Turkije & 0,5 & 0,2 & 0,7 & 0,5 & 0,2 & 0,7 \\
\hline Verenigde Arabische Emiraten & 0,5 & 0,1 & 0,6 & 0,5 & 0,1 & 0,6 \\
\hline Brazilië & 0,4 & 0,1 & 0,5 & 0,5 & 0,1 & 0,6 \\
\hline Mexico & 0,4 & 0,0 & 0,5 & 0,5 & 0,1 & 0,6 \\
\hline Oekraïne & 0,3 & 0,1 & 0,4 & 0,3 & 0,1 & 0,4 \\
\hline Zuid-Afrika & 0,3 & 0,1 & 0,3 & 0,3 & 0,1 & 0,4 \\
\hline Slowakije & 0,2 & 0,1 & 0,3 & 0,2 & 0,1 & 0,4 \\
\hline Israël & 0,3 & 0,0 & 0,3 & 0,3 & 0,0 & 0,3 \\
\hline Taiwan & 0,2 & 0,0 & 0,3 & 0,3 & 0,1 & 0,3 \\
\hline Marokko & 0,3 & 0,0 & 0,3 & 0,3 & 0,0 & 0,3 \\
\hline Kroatië & 0,2 & 0,1 & 0,3 & 0,2 & 0,1 & 0,3 \\
\hline Maleisië & 0,2 & 0,0 & 0,3 & 0,2 & 0,0 & 0,3 \\
\hline Thailand & 0,2 & 0,1 & 0,2 & 0,2 & 0,1 & 0,2 \\
\hline Vietnam & 0,2 & 0,0 & 0,3 & 0,2 & 0,0 & 0,2 \\
\hline Chili & 0,1 & 0,0 & 0,2 & 0,2 & 0,0 & 0,2 \\
\hline Indonesië & 0,2 & 0,0 & 0,2 & 0,2 & 0,0 & 0,2 \\
\hline Nieuw-Zeeland & 0,1 & 0,0 & 0,2 & 0,1 & 0,0 & 0,2 \\
\hline Ivoorkust & 0,1 & 0,0 & 0,1 & 0,2 & 0,0 & 0,2 \\
\hline India & 0,1 & 0,0 & 0,2 & 0,1 & 0,0 & 0,2 \\
\hline Colombia & 0,1 & 0,0 & 0,1 & 0,1 & 0,0 & 0,2 \\
\hline Argentinië & 0,1 & 0,0 & 0,1 & 0,1 & 0,0 & 0,1 \\
\hline Peru & 0,1 & 0,0 & 0,1 & 0,1 & 0,0 & 0,1 \\
\hline Senegal & 0,1 & 0,0 & 0,1 & 0,1 & 0,0 & 0,1 \\
\hline Ecuador & 0,0 & 0,0 & 0,0 & 0,0 & 0,0 & 0,1 \\
\hline Kenia & 0,0 & 0,0 & 0,0 & 0,0 & 0,0 & 0,1 \\
\hline Costa Rica & 0,0 & 0,0 & 0,0 & 0,0 & 0,0 & 0,1 \\
\hline Oeganda & 0,0 & 0,0 & 0,0 & 0,0 & 0,0 & 0,0 \\
\hline Tunesië & 0,0 & 0,0 & 0,0 & 0,0 & 0,0 & 0,0 \\
\hline Angola & 0,0 & 0,0 & 0,0 & 0,0 & 0,0 & 0,0 \\
\hline & 0,0 & 0,0 & 0,0 & 0,0 & 0,0 & 0,0 \\
\hline & & & & & & \\
\hline Ethiopië & 0,0 & \\
\hline
\end{tabular}




\section{Bijlage 5 Vormen van handelsbescherming}

Tabel B5.1 3 Een overzicht van de verschillende vormen van handelsbescherming

\begin{tabular}{|c|c|c|c|c|c|}
\hline \multicolumn{3}{|l|}{ Soort bescherming } & \multicolumn{2}{|l|}{ Uitgedrukt als } & Bron \\
\hline \multirow{7}{*}{$\begin{array}{l}\text { Importtarieven } \\
\text { (ook bekend als } \\
\text { douanetarieven) }\end{array}$} & \multirow{3}{*}{$\begin{array}{l}\text { Ad valorem equivalent } \\
\text { (AVE) }\end{array}$} & Gebonden tarieven & \multirow{3}{*}{\multicolumn{2}{|c|}{$\begin{array}{l}\text { Gemiddelde van directe preferentiële } \\
\text { tarieven. }\end{array}$}} & \multirow{7}{*}{$\begin{array}{l}\text { Market access map van } \\
\text { International Trade Centre }\end{array}$} \\
\hline & & MFN tarieven & & & \\
\hline & & Preferentiële tarieven & & & \\
\hline & \multirow{4}{*}{$\begin{array}{l}\text { Niet ad valorem equivalent } \\
\text { (NAV) }\end{array}$} & Specifieke & \multirow{4}{*}{\multicolumn{2}{|c|}{$\begin{array}{l}\text { Gemiddelde van tot AVE omgerekende } \\
\text { handelstarieven. }\end{array}$}} & \\
\hline & & Compound & & & \\
\hline & & Mixed & & & \\
\hline & & Quota's & & & \\
\hline \multirow[t]{9}{*}{ Wettelijke vereisten } & \multirow{8}{*}{$\begin{array}{l}\text { Sanitaire en Fytosanitaire } \\
\text { (SPS) maatregelen }\end{array}$} & A1: Verboden of beperkingen van producten of stoffen vanwege SPS; & \multirow[t]{3}{*}{ Absolute proxies } & Coverage ratio & \multirow[t]{9}{*}{ CBS, UNCTAD TRAINS } \\
\hline & & A2: Tolerantiegrenzen voor residuen en beperkt gebruik van stoffen & & Frequency ratio & \\
\hline & & A3: Etiketterings-, markerings- en verpakkingsvereisten; & & Prevalence ratio & \\
\hline & & A4: Hygiënische eisen; & & & \\
\hline & & $\begin{array}{l}\text { A5: Behandeling voor de eliminatie van plantaardig en dierlijk } \\
\text { ongedierte en ziekteverwekkende organismen in het eindproduct }\end{array}$ & Relatieve proxies & Regulatory distance & \\
\hline & & A6: Andere vereisten voor productie- of postproductieprocessen & & & \\
\hline & & A8: Conformiteitsbeoordeling met betrekking tot SPS & Handelskosten & $\begin{array}{l}\text { Ad valorem } \\
\text { equivalenten }\end{array}$ & \\
\hline & & A9: SPS maatregelen n.e.g & & & \\
\hline & \multicolumn{4}{|c|}{ egelen, waaronder TBT's, (...) } & \\
\hline
\end{tabular}


Tabel B5.2 Onderverdeling van Non Tarifaire Maatregelen in verschillende hoofdstukken

\begin{tabular}{|c|c|c|c|c|}
\hline $\begin{array}{l}\text { Handels- } \\
\text { stroom }\end{array}$ & Type maatregel & Motivatie maatregel & Hoofdstuk & Omschrijving hoofdstuk \\
\hline \multirow[t]{15}{*}{ Import } & \multirow[t]{3}{*}{ Technische maatregelen } & \multirow[t]{3}{*}{ Kwaliteit en veiligheid } & A & Sanitaire en fytosanitaire maatregelen (SPS) \\
\hline & & & B & Technische handelsbarrières (TBT) \\
\hline & & & C & Inspectie vóór verzending en andere formaliteiten \\
\hline & \multirow[t]{12}{*}{ Niet-technische maatregelen } & $\begin{array}{l}\text { Verdediging binnenlandse } \\
\text { markt }\end{array}$ & D & Voorwaardelijke handelsbeschermende maatregelen \\
\hline & & \multirow[t]{3}{*}{ Handelspolitiek } & $\mathrm{E}$ & $\begin{array}{l}\text { Niet-automatisch verleende vergunningen, importquota en andere kwantitatieve } \\
\text { belemmeringen anders dan voor SPS- of TBT-redenen }\end{array}$ \\
\hline & & & $\mathrm{F}$ & Prijscontrolemaatregelen, inclusief extra belastingen en toeslagen \\
\hline & & & G & Financiële maatregelen \\
\hline & & \multirow[t]{8}{*}{ Behind-the border } & $\mathrm{H}$ & Maatregelen die de mededinging beïnvloeden \\
\hline & & & I & Handelsgerelateerde investeringsmaatregelen \\
\hline & & & J & Distributiebeperkingen op geïmporteerde goederen \\
\hline & & & $\mathrm{K}$ & Beperkingen op after-sales diensten \\
\hline & & & $\mathrm{L}$ & Subsidies \\
\hline & & & M & Beperkende maatregelen op publieke aanbestedingen voor buitenlandse bedrijven \\
\hline & & & $\mathrm{N}$ & Intellectueel eigendom \\
\hline & & & $\mathrm{O}$ & Regels van oorsprong \\
\hline Export & & Handelspolitiek & $\mathrm{P}$ & Export-gerelateerde maatregelen \\
\hline
\end{tabular}




\section{Bijlage 6 Biologische handel}

Tabel B6.1 Overzicht van landen waar de biologische handel van bekend is (waarde in miljoen euro)

\begin{tabular}{|c|c|c|c|c|c|c|}
\hline Landen & Stroom & 2015 & 2016 & 2017 & 2018 & 2019 \\
\hline Argentinië & export & 122 & 122 & 122 & 122 & 122 \\
\hline \multirow[t]{2}{*}{ Australië } & export & 247 & 247 & 486 & 433 & 433 \\
\hline & import & 107 & 107 & 107 & 107 & 107 \\
\hline Belize & export & 0 & 0 & 0 & 0 & 0 \\
\hline Bhutan & export & 0 & 0 & 0 & 3 & 3 \\
\hline Bolivia (Plurinationale Staat) & export & 178 & 178 & 178 & 178 & 178 \\
\hline Bosnië-Herzegovina & export & 2 & 2 & 4 & 6 & 6 \\
\hline Brazilië & export & & 126 & 126 & 126 & 126 \\
\hline Cambodja & export & 0 & 0 & 0 & & \\
\hline \multirow[t]{2}{*}{ Canada } & export & 420 & 434 & 434 & 434 & 310 \\
\hline & import & 456 & 455 & 455 & 455 & 531 \\
\hline \multirow[t]{2}{*}{ Chili } & export & 195 & 240 & 213 & 213 & 244 \\
\hline & import & 10 & 14 & 9 & 9 & 16 \\
\hline China & export & 466 & 1.049 & 1.049 & 806 & \\
\hline Colombia & export & 13 & 13 & 13 & 13 & 13 \\
\hline Costa Rica & export & 18 & 18 & 18 & 18 & 18 \\
\hline \multirow[t]{2}{*}{ Kroatië } & export & 2 & 2 & 2 & 2 & 2 \\
\hline & import & 34 & 34 & 34 & 34 & 34 \\
\hline \multirow[t]{2}{*}{ Tsjechië } & export & 53 & 53 & 60 & 82 & 82 \\
\hline & import & 35 & 35 & 56 & 104 & 104 \\
\hline \multirow[t]{2}{*}{ Denemarken } & export & 265 & 328 & 396 & 389 & 406 \\
\hline & import & 321 & 431 & 518 & 593 & 1.240 \\
\hline Dominicaanse Republiek & export & 293 & 190 & 190 & 423 & 423 \\
\hline Ecuador & export & 43 & 43 & & & \\
\hline \multirow[t]{2}{*}{ Estland } & export & 16 & 16 & 27 & 27 & 54 \\
\hline & import & 3 & 3 & 3 & 3 & \\
\hline Ethiopië & export & 181 & 181 & 181 & 181 & 181 \\
\hline Falkland eilanden & export & 1 & 1 & & & \\
\hline \multirow[t]{2}{*}{ Finland } & export & 10 & 10 & 10 & 27 & 27 \\
\hline & import & 19 & 19 & 19 & 19 & \\
\hline
\end{tabular}

\begin{tabular}{|c|c|c|c|c|c|c|}
\hline Landen & Stroom & 2015 & 2016 & 2017 & 2018 & 2019 \\
\hline \multirow{2}{*}{ Frankrijk } & export & 435 & 629 & 707 & 707 & 826 \\
\hline & import & 720 & 720 & 1.640 & 1.890 & 1.890 \\
\hline \multirow[t]{2}{*}{ Hongarije } & export & 20 & 20 & 20 & 20 & 20 \\
\hline & import & 18 & 18 & 18 & 18 & 18 \\
\hline India & export & 268 & 268 & 456 & 641 & 613 \\
\hline Italië & export & 1.650 & 1.915 & 2.060 & 2.266 & 2.425 \\
\hline Kazachstan & export & 9 & 9 & 9 & 9 & 9 \\
\hline Kenia & export & 27 & 24 & 24 & 24 & 24 \\
\hline Kosovo & export & 6 & 6 & 6 & 6 & 6 \\
\hline Kirgizië & export & & 370 & 417 & 417 & 288 \\
\hline Letland & export & & & 51 & 51 & 51 \\
\hline Litouwen & export & & & 45 & 45 & 45 \\
\hline Mexico & export & 372 & 372 & 372 & 372 & 372 \\
\hline Moldavië & export & 15 & 15 & 15 & 15 & \\
\hline Nederland & export & 928 & & & & \\
\hline Nieuw Zeeland & export & 150 & 150 & 224 & 224 & 224 \\
\hline Paraguay & export & 71 & 71 & & & \\
\hline \multirow[t]{2}{*}{ Peru } & export & 346 & 377 & 365 & 339 & 338 \\
\hline & import & 1 & 1 & 1 & 1 & 1 \\
\hline \multirow[t]{2}{*}{ Republiek van Korea } & export & & & & & 7 \\
\hline & import & 22 & & & 102 & 117 \\
\hline \multirow[t]{2}{*}{ Roemenië } & export & 200 & 200 & 200 & 200 & 200 \\
\hline & import & 35 & 35 & 35 & 35 & 35 \\
\hline Rusland & export & 4 & 4 & 4 & 4 & 4 \\
\hline Samoa & export & 0 & 0 & 0 & 0 & 0 \\
\hline Saoedi-Arabië & import & & & & 119 & 119 \\
\hline Senegal & export & 0 & 0 & 0 & & \\
\hline \multirow[t]{2}{*}{ Servië } & export & 19 & 18 & 18 & 18 & 18 \\
\hline & import & 3 & 3 & 3 & 3 & 3 \\
\hline \multirow[t]{2}{*}{ Slovenië } & import & 23 & 23 & 23 & 23 & 23 \\
\hline & export & 0 & 0 & 0 & 0 & 0 \\
\hline
\end{tabular}

118 | Wageningen Economic Research Rapport 2022-001 


\begin{tabular}{llrrrrr} 
Landen & Stroom & $\mathbf{2 0 1 5}$ & $\mathbf{2 0 1 6}$ & $\mathbf{2 0 1 7}$ & $\mathbf{2 0 1 8}$ & $\mathbf{2 0 1 9}$ \\
Spanje & export & 778 & 890 & 890 & 890 & 890 \\
\hline Sri Lanka & import & 431 & 596 & 596 & 596 & 596 \\
\hline Zweden & export & 258 & 258 & 258 & 258 & 258 \\
\hline Thailand & export & & 83 & 83 & 116 & 116 \\
\hline Tunesië & export & 27 & 27 & 27 & 27 & 27 \\
\hline Turkije & export & 170 & 170 & & 223 & 223 \\
\hline & export & 62 & 77 & 182 & 182 & 182 \\
\hline Oeganda & import & & & 540 & 540 & 540 \\
\hline Oekraïne & export & 49 & 49 & 49 & 49 & 49 \\
\hline & export & 50 & 59 & 99 & 104 & 272 \\
\hline Verenigd Koninkrijk & import & 4 & 4 & 4 & 4 & 4 \\
\hline Verenigde Staten & export & & 193 & 193 & 193 & 193 \\
\hline & export & 2.408 & 2.981 & 479 & 2.981 & 2.981 \\
\hline Vietnam & import & 1.424 & 1.493 & 1.756 & 1.852 & 1.852 \\
\hline & export & 816 & 76 & 76 & & 501 \\
\hline & import & & & & 0 & 0 \\
\hline
\end{tabular}

Bron: Extraction data: 10-12-2021 Source of data: FiBL survey based on national data sources, data from certifiers, Eurostat $\odot$ Research Institute of Organic Agriculture FiBL, www.fibl.org More information: statistics.fibl.org

Tabel B6.2 Overzicht van aandeel biologische importvolume in de EU ten opzichte van het totale geïmporteerde volume in 2020

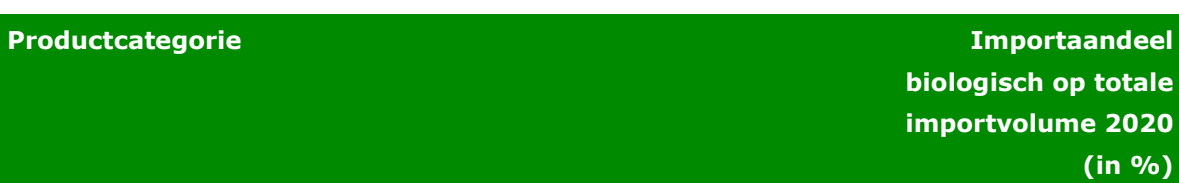

Olijfolie

$\begin{array}{lr}\text { Meel en andere producten van de maalderij } & 15\end{array}$

Bieten- en rietsuiker

Tropisch fruit, noten en specerijen

Diverse zaden en hopbellen

Eieren en honing

Voedselbereidingen, niet gespecificeerd

Bollen, wortels en levende planten

Ongebrande koffie, thee \& mate

Rijst

Fruit, excl. citrus \& tropisch fruit

Vruchtensappen

Cacaobonen

Essentiële oliën

Geurige stoffen

Groenten

Bereidingen van groenten, fruit of noten 3

\begin{tabular}{ll} 
Suiker, andere dan bieten \& suikerriet & 3 \\
\hline Gommen, harsen en plantenextracten & 3 \\
\hline
\end{tabular}

Zetmeel, inuline \& gluten 2

Oliehoudende zaden, andere dan sojabonen 2

Citrusvrucht

Wijn, vermout, cider en azijn $\quad 2$

Soepen en sauzen 2

Babyvoeding en andere graan-, meel-, zetmeel- of melkbereidingen 2

\begin{tabular}{lr} 
Gebrande koffie en thee & 2 \\
\hline Oliekoekjes & 1
\end{tabular}

Sojabonen

Granen, met uitzondering van tarwe en rijst

Palm \& palmpitolie

Suikeralcoholen 


\section{Bijlage 7 Structuurgegevens biologische landbouw}

Om enig inzicht te krijgen in de omvang van de biologische sector, geeft tabel B7.1 voor de EU 27 het areaal biologisch en het percentage biologisch areaal ten opzichte van het totale landbouwareaal. Spanje heeft absoluut gezien het grootste biologisch areaal. Op basis van aandeel staat Oostenrijk bovenaan met ruim 25\%. Nederland heeft met een aandeel van 3,8\% en een totaal van ongeveer 70.000 ha een plek in de onderste helft van deze ranglijsten.

Tabel B7.1 Biologisch areaal (in ha) en aandeel biologisch areaal op totaal areaal landbouwgrond voor Europese landen

\begin{tabular}{|c|c|c|c|c|c|c|c|c|}
\hline & ha in 2013 & $\begin{array}{l}\text { ndeel } \\
2013\end{array}$ & ha in 2015 & $\begin{array}{l}\text { aandeel } \\
\text { in } 2015\end{array}$ & ha in 2017 & $\begin{array}{l}\text { aandeel } \\
\text { in } 2017\end{array}$ & $\begin{array}{l}\text { ha in } \\
2019\end{array}$ & $\begin{array}{l}\text { aandeel } \\
\text { in } 2019\end{array}$ \\
\hline & & $(\%)$ & & (\%) & & (\%) & & (\%) \\
\hline België & 62.471 & 4,7 & 68.818 & 5,2 & 83.508 & 6,3 & 93.119 & 6,9 \\
\hline Bulgarije & 56.287 & 1,1 & 118.552 & 2,4 & 136.618 & 2,7 & 117.779 & 2,3 \\
\hline Cyprus & 4.315 & 4,0 & 4.699 & 3,7 & 5.616 & 4,6 & 6.240 & 5,0 \\
\hline Denemarken & 169.310 & 6,4 & 166.788 & 6,3 & 226.307 & 8,6 & 291.247 & 11,1 \\
\hline Duitsland & 1.008 .926 & 6,0 & 1.060 .291 & 6,3 & 1.138 .272 & 6,8 & 1.290 .839 & 7,8 \\
\hline Estland & 151.164 & 15,7 & 155.806 & 15,7 & 196.441 & 20,0 & 220.737 & 22,3 \\
\hline Finland & 204.810 & 9,1 & 225.235 & 9,9 & 259.271 & 11,4 & 306.484 & 13,5 \\
\hline Frankrijk & 1.060 .755 & 3,7 & 1.322 .911 & 4,5 & 1.744 .420 & 6,0 & 2.240 .797 & 7,7 \\
\hline Griekenland & 383.606 & 7,4 & 407.069 & 7,7 & 410.140 & 8,0 & 528.752 & 10,3 \\
\hline Hongarije & 130.990 & 2,5 & 129.735 & 2,4 & 199.683 & 3,7 & 303.190 & 5,7 \\
\hline Ierland & 53.812 & 1,2 & 73.037 & 1,7 & 74.336 & 1,7 & 73.952 & 1,6 \\
\hline Italië & 1.317 .177 & 10,6 & 1.492 .571 & 11,8 & 1.908 .570 & 14,7 & 1.993 .225 & 15,2 \\
\hline Kroatië & 40.660 & 3,1 & 75.883 & 4,9 & 96.618 & 6,5 & 108.127 & 7,2 \\
\hline Letland & 185.752 & 9,9 & 231.608 & 12,3 & 268.870 & 13,9 & 289.796 & 14,8 \\
\hline Litouwen & 165.885 & 5,7 & 213.579 & 7,1 & 234.134 & 8,0 & 242.118 & 8,1 \\
\hline Luxemburg & 4.447 & 3,4 & 4.216 & 3,2 & 5.444 & 4,2 & 5.814 & 4,4 \\
\hline Malta & 7 & 0,1 & 30 & 0,3 & 41 & 0,4 & 55 & 0,5 \\
\hline Nederland & 48.936 & 2,7 & 49.273 & 2,7 & 59.209 & 3,3 & 68.068 & 3,8 \\
\hline
\end{tabular}

\begin{tabular}{|c|c|c|c|c|c|c|c|c|}
\hline & ha in 2013 & $\begin{array}{r}\text { aandeel } \\
\text { in } 2013 \\
(\%)\end{array}$ & ha in 2015 & $\begin{array}{r}\text { aandeel } \\
\text { in } 2015 \\
(\%)\end{array}$ & ha in 2017 & $\begin{array}{r}\text { aandeel } \\
\text { in } 2017 \\
(\%)\end{array}$ & $\begin{array}{l}\text { ha in } \\
2019\end{array}$ & $\begin{array}{r}\text { aandeel } \\
\text { in } 2019 \\
(\%)\end{array}$ \\
\hline Oostenrijk & 526.689 & 18,4 & 552.141 & 20,3 & 620.656 & 23,4 & 671.703 & 25,3 \\
\hline Polen & 669.863 & 4,7 & 580.731 & 4,0 & 494.978 & 3,4 & 507.637 & 3,5 \\
\hline Portugal & 197.295 & 5,3 & 241.375 & 6,5 & 253.786 & 7,0 & 293.213 & 8,2 \\
\hline Roemenië & 286.896 & 2,1 & 245.924 & 1,8 & 258.471 & 1,9 & 395.228 & 2,9 \\
\hline Slovenië & 38.664 & 8,1 & 42.188 & 8,9 & 46.222 & 9,6 & 49.638 & 10,4 \\
\hline Slowakije & 157.848 & 8,2 & 181.882 & 9,5 & 189.148 & 9,9 & 197.565 & 10,3 \\
\hline Spanje & 1.610 .129 & 6,9 & 1.968 .570 & 8,2 & 2.082 .173 & 8,7 & 2.354 .916 & 9,7 \\
\hline Tsjechië & 474.231 & 13,5 & 478.033 & 13,7 & 496.277 & 14,1 & 535.185 & 15,2 \\
\hline Zweden & 500.996 & 16,5 & 518.983 & 17,1 & 576.845 & 19,2 & 613.964 & 20,4 \\
\hline
\end{tabular}

Bron: Eurostat, bewerking Wageningen Economic Research.

Het biologisch landbouwareaal bestaat voor de top vijf landen vooral uit blijvend grasland, granen en uit voedergewassen zoals snijmais, lupine en klaver.

\section{Biologisch gehouden dieren}

Naast het biologisch areaal worden ook dieren op een biologische wijze gehouden.

Wat betreft runderen is Duitsland koploper in absolute zin, gevolgd Frankrijk en Oostenrijk. Italië en Zweden bezetten met 300.000 tot 400.000 stuks de vierde en vijfde plaats. Nederland heeft relatief weinig biologisch gehouden runderen (tabel B7.2). Op basis van aandeel springen Griekenland, Letland, Zweden, Oostenrijk en Tsjechië er uit. 
Tabel B7.2 Aantal stuks biologisch gehouden runderen en het aandeel (\%) van het totaal gehouden runderen

\begin{tabular}{|c|c|c|c|c|c|c|c|c|}
\hline & $\begin{array}{r}\text { dieren } \\
\text { in } 2013\end{array}$ & $\begin{array}{l}\text { aandeel } \\
\text { in } 2013\end{array}$ & $\begin{array}{r}\text { dieren } \\
\text { in } 2015\end{array}$ & $\begin{array}{l}\text { aandeel } \\
\text { in } 2015\end{array}$ & $\begin{array}{r}\text { dieren } \\
\text { in } 2017\end{array}$ & $\begin{array}{l}\text { aandeel } \\
\text { in } 2017\end{array}$ & $\begin{array}{r}\text { dieren } \\
\text { in } 2019\end{array}$ & $\begin{array}{l}\text { aandeel } \\
\text { in } 2019\end{array}$ \\
\hline België & 76.214 & 3,1 & 80.405 & 3,2 & 108.016 & 4,5 & 107.690 & 4,5 \\
\hline Bulgarije & 1.311 & 0,2 & 4.209 & 0,7 & 10.400 & 1,9 & 9.402 & 1,8 \\
\hline Cyprus & 0 & 0,0 & 101 & 0,2 & 506 & 0,8 & 731 & 1,0 \\
\hline Denemarken & 181.508 & 11,5 & 157.527 & 10,1 & 199.870 & 12,8 & 224.348 & 15,0 \\
\hline Duitsland & 621.800 & 4,9 & 654.386 & 5,1 & 788.561 & 6,4 & 870.372 & 7,5 \\
\hline Estland & 30.017 & 11,5 & 34.312 & 13,0 & 40.049 & 16,0 & 42.290 & 16,6 \\
\hline Finland & 49.101 & 5,4 & 59.700 & 6,6 & 68.197 & 7,8 & 76.173 & 9,1 \\
\hline Frankrijk & 550.121 & 2,9 & 541.312 & 2,8 & 649.856 & 3,4 & 830.921 & 4,6 \\
\hline Griekenland & 71.034 & 10,9 & 68.454 & $10,4 \%$ & 81.425 & $14,6 \%$ & 142.609 & $26,9 \%$ \\
\hline Hongarije & 19.273 & 2,5 & 18.919 & $2,4 \%$ & 17.741 & $2,0 \%$ & 27.007 & $3,0 \%$ \\
\hline Ierland & 37.473 & 0,6 & 46.946 & $0,8 \%$ & 56.873 & $0,9 \%$ & 64.093 & $1,0 \%$ \\
\hline Italië & 231.641 & 3,7 & 266.576 & $4,4 \%$ & 336.278 & $5,3 \%$ & 389.665 & $6,1 \%$ \\
\hline Kroatië & 6.540 & 1,5 & 7.002 & $1,6 \%$ & 17.226 & $3,8 \%$ & 21.551 & $5,1 \%$ \\
\hline Letland & 71.707 & 17,6 & 80.400 & $19,1 \%$ & 95.585 & $23,6 \%$ & 99.041 & $25,1 \%$ \\
\hline Litouwen & 34.163 & 4,8 & 34.929 & 4,7 & 57.270 & 8,5 & 58.356 & 9,2 \\
\hline Luxemburg & 3.373 & 1,7 & 3.576 & 1,8 & 4.177 & 2,1 & 4.814 & 2,5 \\
\hline Malta & 0 & 0,0 & 0 & 0,0 & 0 & 0,0 & 0 & 0,0 \\
\hline Nederland & 53.704 & 1,3 & 56.264 & 1,3 & 65.189 & 1,6 & 71.817 & 1,9 \\
\hline Oostenrijk & 376.973 & 19,3 & 266.236 & 13,6 & 422.008 & 21,7 & 420.693 & 22,4 \\
\hline Polen & 44.663 & 0,8 & 31.896 & 0,6 & 27.901 & 0,5 & 30.186 & 0,5 \\
\hline Portugal & 69.095 & 4,7 & 97.320 & 6,3 & 86.881 & 5,2 & 95.306 & 5,7 \\
\hline Roemenië & 20.113 & 1,0 & 29.313 & 1,4 & 19.339 & 1,0 & 19.358 & 1,0 \\
\hline Slovenië & 25.168 & 5,5 & 30.592 & 6,5 & 35.095 & 7,3 & 37.126 & 7,7 \\
\hline Slowakije & 43.142 & 9,2 & 58.945 & 12,7 & 55.906 & 12,7 & 61.432 & 14,2 \\
\hline Spanje & 151.571 & 2,6 & 190.224 & 3,1 & 207.121 & 3,2 & 215.802 & 3,3 \\
\hline Tsjechië & 213.303 & 16,0 & 237.635 & 17,3 & 255.978 & 18,7 & 262.910 & 19,2 \\
\hline Zweden & 285.670 & 19,8 & 285.774 & 19,9 & 307.120 & 21,2 & 333.245 & 23,7 \\
\hline
\end{tabular}

Bron: Eurostat, bewerking Wageningen Economic Research.

Denemarken is de belangrijkste speler op het gebied van de biologische varkenshouderij, gevolgd door Frankrijk, Duitsland, Nederland en Oostenrijk (tabel B7.3).
Tabel B7.3 Aantal stuks biologisch gehouden varkens en het aandeel (\%) van het totaal gehouden varkens

\begin{tabular}{|c|c|c|c|c|c|c|c|c|}
\hline & $\begin{array}{r}\text { dieren } \\
\text { in } 2013\end{array}$ & $\begin{array}{l}\text { aandeel } \\
\text { in } 2013\end{array}$ & $\begin{array}{r}\text { dieren } \\
\text { in } 2015\end{array}$ & $\begin{array}{l}\text { aandeel } \\
\text { in } 2015\end{array}$ & $\begin{array}{r}\text { dieren } \\
\text { in } 2017\end{array}$ & $\begin{array}{l}\text { aandeel } \\
\text { in } 2017\end{array}$ & $\begin{array}{r}\text { dieren } \\
\text { in } 2019\end{array}$ & $\begin{array}{l}\text { aandeel } \\
\text { in } 2019\end{array}$ \\
\hline België & 11.350 & 0,2 & 10.274 & 0,2 & 17.771 & 0,3 & 17.081 & 0,3 \\
\hline Bulgarije & 0 & 0,0 & 37 & 0,0 & 276 & 0,0 & 91 & 0,0 \\
\hline Cyprus & 0 & 0,0 & 0 & 0,0 & 0 & 0,0 & 0 & 0,0 \\
\hline Denemarken & 239.453 & 1,9 & 260.510 & 2,1 & 374.963 & 2,9 & 490.924 & 3,9 \\
\hline Duitsland & 193.900 & 0,7 & 190.471 & 0,7 & 193.338 & 0,7 & 182.653 & 0,7 \\
\hline Estland & 1.141 & 0,3 & 861 & 0,3 & 571 & 0,2 & 683 & 0,2 \\
\hline Finland & 5.442 & 0,4 & 6.131 & 0,5 & 5.074 & 0,5 & 5.156 & 0,5 \\
\hline Frankrijk & 201.201 & 1,5 & 219.812 & 1,7 & 282.286 & 2,1 & 437.950 & 3,2 \\
\hline Griekenland & 4.797 & 0,5 & 4.203 & 0,5 & 4.434 & 0,6 & 4.994 & 0,7 \\
\hline Hongarije & 4.880 & 0,2 & 4.023 & 0,1 & 5.333 & 0,2 & 5.486 & 0,2 \\
\hline Ierland & 489 & 0,0 & 443 & 0,0 & 708 & 0,0 & 518 & 0,0 \\
\hline Italië & 43.318 & 0,5 & 49.909 & 0,6 & 61.242 & 0,7 & 51.765 & 0,6 \\
\hline Kroatië & 1.122 & 0,1 & 1.114 & 0,1 & 1.468 & 0,1 & 2.873 & 0,3 \\
\hline Letland & 4.804 & 1,3 & 2.838 & 0,8 & 2.571 & 0,8 & 1.925 & 0,6 \\
\hline Litouwen & 377 & 0,0 & 189 & 0,0 & 112 & 0,0 & 131 & 0,0 \\
\hline Luxemburg & 926 & 1,0 & 908 & 1,0 & 860 & 0,9 & 1.026 & 1,2 \\
\hline Malta & 0 & 0,0 & 0 & 0,0 & 0 & 0,0 & 0 & 0,0 \\
\hline Nederland & 63.588 & 0,5 & 69.102 & 0,6 & 87.542 & 0,7 & 106.458 & 0,9 \\
\hline Oostenrijk & 70.935 & 2,4 & 78.246 & 2,7 & 73.302 & 2,6 & 74.603 & 2,7 \\
\hline Polen & 9.771 & 0,1 & 6.309 & 0,1 & 3.893 & 0,0 & 4.189 & 0,0 \\
\hline Portugal & 2.009 & 0,1 & 833 & 0,0 & 1.157 & 0,1 & 6.757 & 0,3 \\
\hline Roemenië & 258 & 0,0 & 86 & 0,0 & 20 & 0,0 & 9 & 0,0 \\
\hline Slovenië & 2.798 & 1,0 & 3.345 & 1,2 & 3.793 & 1,5 & 3.252 & 1,4 \\
\hline Slowakije & 187 & 0,0 & 503 & 0,1 & 158 & 0,0 & 642 & 0,1 \\
\hline Spanje & 7.795 & 0,0 & 10.741 & 0,0 & 9.938 & 0,0 & 32.343 & 0,1 \\
\hline Tsjechië & 1.860 & 0,1 & 1.761 & 0,1 & 2.101 & 0,1 & 2.707 & 0,2 \\
\hline Zweden & 20.548 & 1,4 & 26.739 & 1,9 & 30.766 & 2,2 & 36.649 & 2,5 \\
\hline
\end{tabular}

Bron: Eurostat, bewerking Wageningen Economic Research.

Biologisch pluimvee is vooral in Frankrijk te vinden (tabel B7.4). Daarnaast zijn, op gepaste afstand, Nederland en België hier belangrijke spelers in absolute aantallen gemeten. Het aandeel van biologisch gehouden pluimvee ten opzichte van het totaal is op basis van Eurostat gegevens niet te geven. 
Tabel B7.4 Aantal stuks biologisch gehouden pluimvee (top vijf Europese landen)

\begin{tabular}{lrrr} 
& $\mathbf{2 0 1 7}$ & $\mathbf{2 0 1 8}$ & $\mathbf{2 0 1 9}$ \\
Frankrijk & 17.128 .000 & 20.181 .000 & 22.714 .000 \\
\hline België & 3.305 .000 & 4.096 .000 & 4.592 .000 \\
\hline Nederland & 3.306 .000 & 3.734 .000 & 3.926 .000 \\
\hline Verenigd Koninkrijk & 3.060 .000 & 3.383 .000 & 3.465 .000 \\
\hline Denemarken & 3.856 .000 & 3.507 .000 & 3.349 .000 \\
\hline
\end{tabular}

Bron: Eurostat.

Bij zowel het areaal als bij het houden van dieren op biologische wijze is over het algemeen een toename te zien tussen 2017 en 2019; dit rijmt met de toename van de consumptie van biologische producten. 
Wageningen Economic Research

Postbus 29703

2502 LS Den Haag

T 0703358330

E communications.ssg@wur.n

www.wur.nl/economic-research

Wageningen Economic Research

RAPPORT

2022-001

ISBN 978-94-6447-076-5
De missie van Wageningen University \& Research is 'To explore the potential of nature to improve the quality of life'. Binnen Wageningen University \& Research bundelen Wageningen University en gespecialiseerde onderzoeksinstituten van Stichting Wageningen Research hun krachten om bij te

dragen aan de oplossing van belangrijke vragen in het domein van gezonde voeding en

leefomgeving. Met ongeveer 30 vestigingen, 6.800 medewerkers (6.000 fte) en 12.900 studenten

behoort Wageningen University \& Research wereldwijd tot de aansprekende kennisinstellingen binnen

haar domein. De integrale benadering van de vraagstukken en de samenwerking tussen verschillende

disciplines vormen het hart van de unieke Wageningen aanpak. 